\title{
GEOTECHNICAL RECONNAISSANCE OF THE 2010 DARFIELD (CANTERBURY) EARTHQUAKE
}

\author{
Editors: Misko Cubrinovski ${ }^{1}$, Russell A. Green ${ }^{2}$ \\ Contributing authors (alphabetical order): \\ John Allen ${ }^{3}$, Scott Ashford ${ }^{4}$, Elisabeth Bowman ${ }^{1}$, Brendon \\ Bradley $^{1}$, Brady Cox ${ }^{5}$, Misko Cubrinovski ${ }^{1}$, Russell A. Green ${ }^{2}$, \\ Tara Hutchinson ${ }^{6}$, Edward Kavazanjian ${ }^{7}$, Rolando Orense ${ }^{8}$, \\ Michael Pender ${ }^{8}$, Mark Quigley ${ }^{1}$, Liam Wotherspoon ${ }^{8}$
}

\begin{abstract}
SUMMARY
On 4 September 2010, a magnitude $M_{w} 7.1$ earthquake struck the Canterbury region on the South Island of New Zealand. The epicentre of the earthquake was located in the Darfield area about $40 \mathrm{~km}$ west of the city of Christchurch. Extensive damage was inflicted to lifelines and residential houses due to widespread liquefaction and lateral spreading in areas close to major streams, rivers and wetlands throughout Christchurch and Kaiapoi. Unreinforced masonry buildings also suffered extensive damage throughout the region. Despite the severe damage to infrastructure and residential houses, fortunately, no deaths occurred and only two injuries were reported in this earthquake. From an engineering viewpoint, one may argue that the most significant aspects of the 2010 Darfield Earthquake were geotechnical in nature, with liquefaction and lateral spreading being the principal culprits for the inflicted damage.

Following the earthquake, an intensive geotechnical reconnaissance was conducted to capture evidence and perishable data from this event. The surveys were performed on foot, by car and from a helicopter over a period of six days. A broad-brush field reconnaissance was conducted in the first two days, followed by pin-point investigations at specific locations including detailed site inspections and field testing using: Dynamic Cone Penetration Test (DCPT), Swedish Weight Sounding (SWS), and Spectral Analysis of Surface Waves (SASW).
\end{abstract}

This paper summarizes the observations and preliminary findings from this early reconnaissance work.

\footnotetext{
${ }^{1}$ University of Canterbury, Christchurch, New Zealand

${ }^{2}$ Virginia Tech, Blacksburg, VA, USA

${ }^{3}$ TRI/Environmental, Inc., Austin, TX, USA

${ }^{4}$ Oregon State University, Corvallis, OR, USA

${ }^{5}$ University of Arkansas, Fayetteville, AR, USA

${ }^{6}$ University of California, San Diego, CA, USA

${ }^{7}$ Arizona State University, Tempe, AZ, USA

${ }^{8}$ University of Auckland, Auckland, New Zealand
} 


\section{INTRODUCTION}

On 4 September 2010, a magnitude $M_{w} 7.1$ earthquake struck the Canterbury region on the South Island of New Zealand. The epicentre of the earthquake was located in the Darfield area about $40 \mathrm{~km}$ west of the city of Christchurch. Extensive damage occurred to unreinforced masonry buildings throughout the region during the mainshock and subsequent large aftershocks. Particularly extensive damage was inflicted to lifelines and residential houses due to widespread liquefaction and lateral spreading in areas close to major streams, rivers and wetlands throughout Christchurch and Kaiapoi. Despite the severe damage to infrastructure and residential houses, fortunately, no deaths occurred and only two injuries were reported in this earthquake. From an engineering viewpoint, one may argue that the most significant aspects of the 2010 Darfield Earthquake were geotechnical in nature, with liquefaction and lateral spreading being the principal culprits for the inflicted damage.

Following the earthquake, a geotechnical reconnaissance was conducted over a period of six days (10-15 September 2010) by a team of geotechnical/earthquake engineers and geologists from New Zealand and USA (GEER team: Geo-engineering Extreme Event Reconnaissance). The team included the following members:

Assoc. Prof. Misko Cubrinovski - NZ Lead (University of Canterbury, Christchurch, New Zealand)

Assoc. Prof. Russell A. Green - US Lead (Virginia Tech, Blacksburg, VA, USA)

Mr. Tom Algie - (University of Auckland, Auckland, New Zealand)

Mr. John Allen - (TRI/Environmental, Inc., Austin, TX, USA)

Prof. Scott Ashford - (Oregon State University, Corvallis, OR, USA)

Mr. Jawad Arefi - (University of Canterbury, Christchurch, New Zealand)

Dr. Elisabeth Bowman - (University of Canterbury, Christchurch, New Zealand)

Dr. Brendon Bradley - (University of Canterbury,

Christchurch, New Zealand)

Assist. Prof. Brady Cox - (University of Arkansas, Fayetteville, AR, USA)

Mr. William Godwin - (Fugro William Lettis and Associates, Inc., Walnut Creek, CA, USA)

Prof. Tara Hutchinson - (University of California, San Diego, CA, USA)

Prof. Edward Kavazanjian - (Arizona State University, Tempe, AZ, USA)

Dr. Tam Larkin - (University of Auckland, Auckland, New Zealand)

Dr. Rolando Orense - (University of Auckland, Auckland, New Zealand)

Prof. Michael Pender - (University of Auckland, Auckland, New Zealand)

Dr. Mark Quigley - (University of Canterbury, Christchurch, New Zealand)

Ms. Kelly Robinson - (University of Canterbury, Christchurch, New Zealand)

Mr. Merrick Taylor - (University of Canterbury, Christchurch, New Zealand)

Dr. Thomas Wilson - (University of Canterbury, Christchurch, New Zealand)

Dr. Liam Wotherspoon - (University of Auckland, Auckland, New Zealand)
The following JGS (Japanese Geotechnical Society) members from Japan also participated in the reconnaissance team from 13 to 15 September 2010:

Prof. Mitsu Okamura - JGS Lead (Ehime University, Matsuyama, Japan)

Assoc. Prof. Takashi Kiyota - (Institute of Industrial Science, University of Tokyo, Tokyo, Japan)

Assoc. Prof. Hirofumi Toyota - (Nagaoka University of Technology, Nagaoka, Japan)

The NZ, GEER and JGS members worked as one team and shared resources, information and logistics in order to conduct a thorough and efficient reconnaissance covering a large area over a very limited time period. This paper summarises the key evidence and findings from the reconnaissance. Any opinions, findings, and conclusions or recommendations expressed in this paper are those of the authors and do not necessarily reflect the views of the associated organisations and funding agencies.

\section{GEOLOGICAL ASPECTS}

\subsection{Summary}

At 4:35 am on September $4^{\text {th }}$ NZ Standard Time (16:35 Sept $3^{\text {rd }}$ UTC) the rupture of a previously unrecognized strike-slip fault beneath the Canterbury Plains of New Zealand's South Island produced a $\mathrm{M}_{\mathrm{w}} 7.1$ earthquake. Although this earthquake caused widespread damage to the Canterbury region, it also allowed documenting the dynamics and effects of a major strike-slip fault rupture in the fortuitous absence of death or major injuries. The low relief and well maintained agricultural landscape of the Canterbury Plains has provided an ideal environment to characterise even the most subtle of earthquake-related ground deformation at high resolution. This chapter summarizes the basic geological context and ground rupture characteristics of the earthquake.

\subsection{Geological context for the Darfield (Canterbury) earthquake}

The tectonic plate boundary between the Australian (A) and Pacific (P) Plates passes through the South Island of New Zealand, where subduction of the Hikurangi Plateau to the north transitions into a continent-continent collision zone associated with the collision of the Chatham Rise with continental crust of the Australian Plate (Figure 2.1). The A and $\mathrm{P}$ plates converge obliquely at $48-39 \mathrm{~mm} / \mathrm{yr}$ in New Zealand. The resultant collision zone between these plates is not a line on a map; rather it is a distributed zone of active faults each with their own capability of generating large earthquakes throughout/around New Zealand. The Marlborough Fault Zone consists of a series of large, 'transpressional' faults that record primarily right-lateral displacement with a component of shortening, resulting in mountain uplift. These faults ultimately link to the Alpine Fault, which accommodates $\sim 70-75 \%$ of the total relative plate boundary motion between the A-P Plates with a values of $27 \pm$ $5 \mathrm{~mm} / \mathrm{yr}$ of strike-slip and 5-10 mm/yr of dip-slip (Norris \& Cooper 2001). The remaining $~ 30 \%$ of A-P plate motion is accommodated by slip on a series of faults throughout the Southern Alps and Canterbury Plains. The Greendale Fault, which was the source of the 2010 Darfield (Canterbury) earthquake, is one of these structures, although it was not recognized prior to this earthquake. Much of the motion is likely taken up on the other big faults, such as the Porter's Pass Fault, which has a slip rate of 3-7 mm/yr (3-5 mm/yr; e.g. Cowan et al. 1996; Howard et al. 2005; 7 mm/yr; Wallace et al., 2007). Modelling of GPS-derived velocity fields suggests a strain rate of $\sim 2 \mathrm{~mm} / \mathrm{yr}$ of $\mathrm{WNW}$ oriented 
permanent contraction for the region east of the Porter's Pass Fault to offshore of Christchurch that hosts the Greendale Fault ("Canterbury Block"; Wallace et al., 2007). There are several structures in this region, both expressed at the surface and 'hidden' beneath the surface, that pose an earthquake hazard to Christchurch (e.g., Hororata Fault, Hororata anticline, Springbank Fault, Bobby's Creek Fault, Greendale Fault). E-W trending faults are present throughout Canterbury and offshore on the Chatham Rise, and some of these are now 'active' faults (i.e. faults that have had large earthquakes in the last $\sim 10,000 \mathrm{yrs}$ and/or have the potential to generate earthquakes in the modern setting). In a general sense, E-W trending faults like the Greendale fault tend to be strike-slip dominated faults (e.g., Porter's Pass Fault; Bobby's Creek Fault, Ashley Fault) while NE-SW to N-S trending faults tend to be reverse-slip dominated faults with smaller components of strike-slip (e.g., Springfield Fault, Springbank Fault, Hororata Fault). As is clear from this recent earthquake, it is important to obtain more information on the locations of all active faults beneath the Canterbury Plains (via geophysical and mapping investigations) and earthquake histories of all faults (via mapping and paleoseismic analysis) in order to better understand the risk that these structures pose to the Canterbury region (Pettinga et al., 2001).

\subsection{The September 2010 Darfield (Canterbury) Earthquake}

The epicentre of the Darfield Earthquake was located approximately $10 \mathrm{~km}$ southeast of the town of Darfield (Figure 2.2 ) with a focal depth of $\sim 10 \mathrm{~km}$. Preliminary USGS and global centroid moment tensor solutions indicated the mainshock was associated with almost pure dextral (rightlateral) strike-slip slip on a subvertical nearly E-W striking fault plane. The event produced $\mathrm{a} \geq 28 \mathrm{~km}$ long, dextral strikeslip surface rupture trace, aligned approximately west-east (Figure 2.2). Using data from New Zealand national and strong-motion seismic networks, GNS seismologists have proposed that the rupture process involved a component of reverse faulting at depth. In the month following the mainshock, the region has incurred thousands of aftershocks of $M_{L}>2$ including eleven aftershocks of $M_{L} \geq 5.0$. A $M_{L} 5.2$ aftershock on September $8^{\text {th }}$ (NZST) located $\sim 7 \mathrm{~km}$ southeast of the Christchurch city centre at a depth of $\sim 6 \mathrm{~km}$ caused further damage to city infrastructure. The frequency of $\mathrm{M}_{\mathrm{L}}>2$ aftershocks has decreased by an order of magnitude since the days immediately following the mainshock although the possibility of $M \geq 5$ earthquakes still remains, as the region adjusts to the crustal deformation associated with the mainshock.

Aftershock distributions proximal to the E-W trending part of the Greendale fault are dominated by $\sim \mathrm{E}-\mathrm{W}$ trending dextral strike-slip mechanisms, as expected from kinematic analysis of the patterns of ground rupture. A NE-trending cloud of aftershocks west of the Greendale fault, between Hororata and the Rakaia River is dominated by $\sim \mathrm{NE}$ trending thrust fault mechanisms. A NE-trending cloud of aftershocks north of the Greendale fault, between Darfield and the Waimakariri River is a mixture of $\sim \mathrm{NE}$ trending thrust fault and strike-slip fault mechanisms. A NNW-trending swarm of seismicity from $\sim 5$ $\mathrm{km}$ north of Rolleston south to Lincoln consists of a mixture of NW-trending normal fault mechanisms and (probably) E-W trending dextral strike slip mechanisms.

The NE and NW trending belts of seismicity are consistent with field observations of subtle deformation in these localities although these aspects require further research.

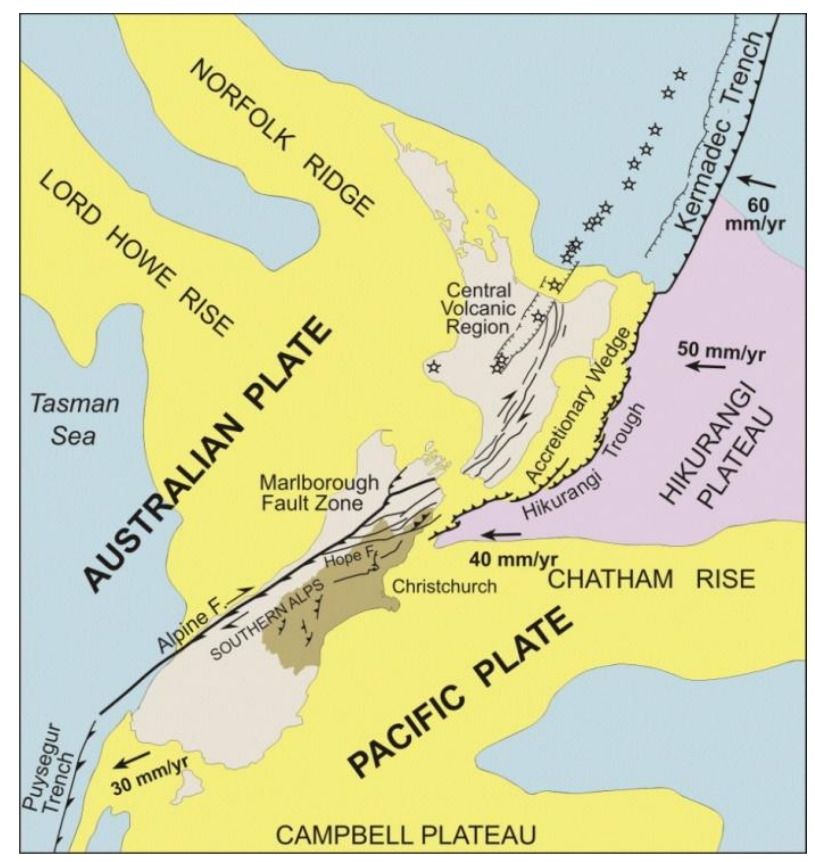

Figure 2.1: A-P plate boundary through New Zealand and convergence rates of $P$ relative to $A$ Plate. (Image courtesy of Jarg Pettinga).

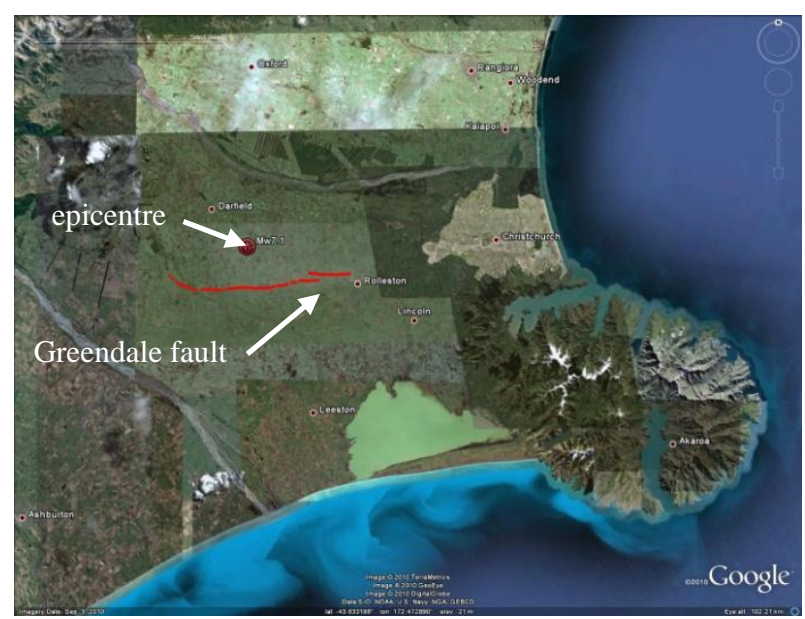

Figure 2.2: $\quad$ Aerial image of the Christchurch area with the surface fault rupture and the epicentre of the Darfield earthquake are denoted. The image is $\sim 117 \mathrm{~km}$ across.

\subsection{Characteristics of the surface fault rupture}

The zone of identified surface rupture extends from $\sim 4 \mathrm{~km}$ WNW of the hamlet of Greendale for about $28 \mathrm{~km}$ to an eastern tip $\sim 2 \mathrm{~km} \mathrm{NW}$ of the town of Rolleston (Figure 2.2). Offsets and fracture patterns reveal up to 4.6 meters of displacement, with an average displacement of $\sim 2.3 \mathrm{~m}$ across the entire rupture. Figure 2.3 shows comparisons of the average and maximum fault displacements with global fault data compiled by Wells and Coppersmith (1994). As may be observed from these comparisons, the average and maximum displacements are slightly larger, but very close to, the best fit line of the global fault data. The displacement on the Greendale fault during the Darfield earthquake was dominated by dextral (right lateral) movement (Figure 2.4). 

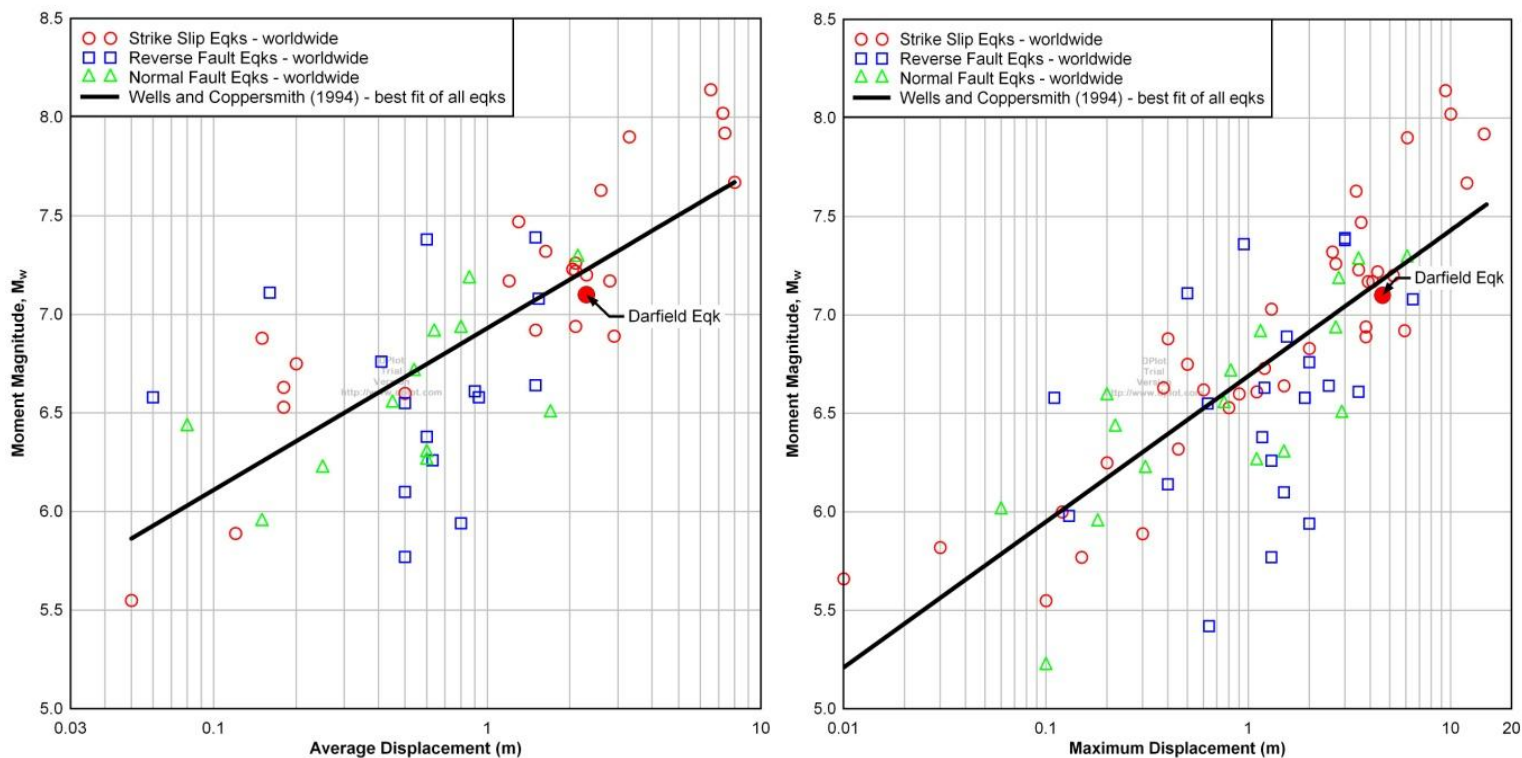

Figure 2.3: $\quad$ Comparisons of average (top) and maximum (bottom) surface rupture displacements for the Darfield earthquake with global fault data compiled by Wells and Coppersmith (1994). (Global fault data courtesy of Don Wells).
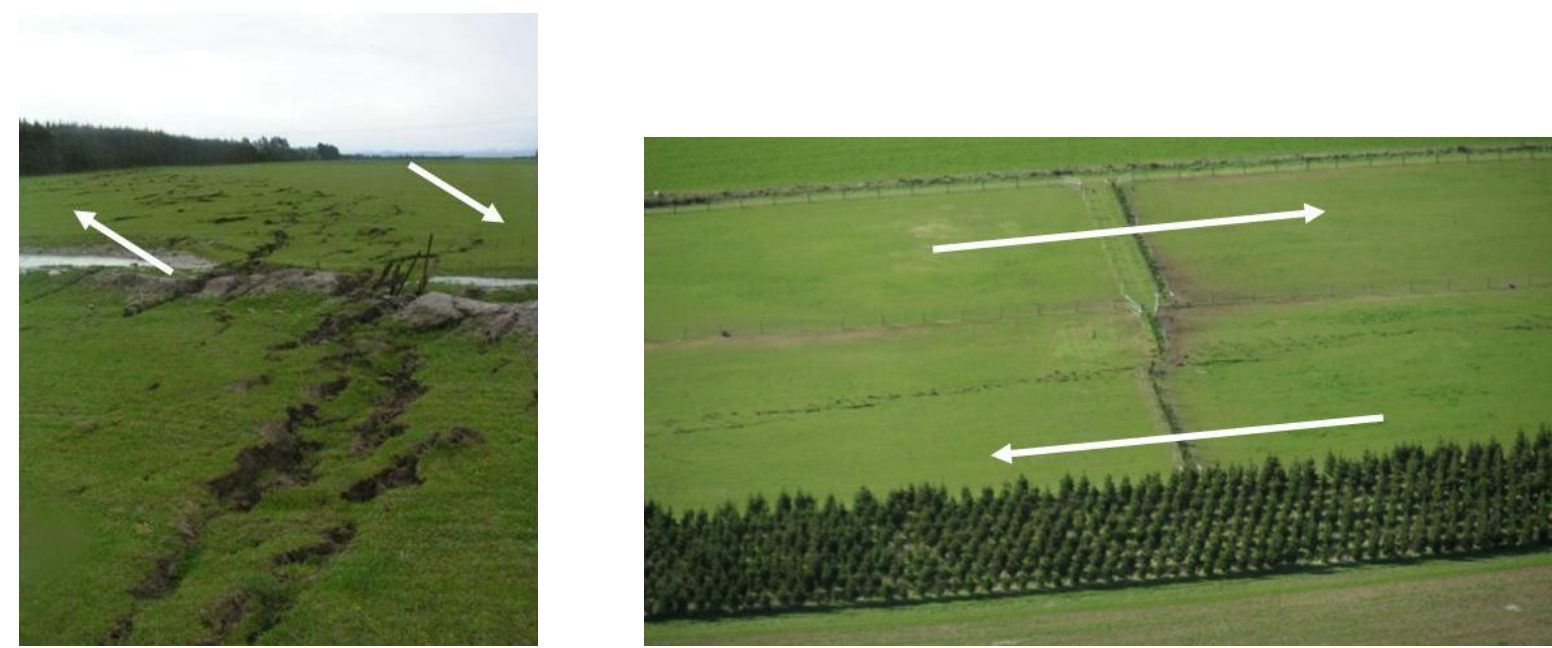

Figure 2.3: $\quad$ Photographs of surface fault rupture on the Greendale fault. (Left photo: http://daveslandslideblog.blogspot.com/2010/09/images-of-darfield-canterbury.html).

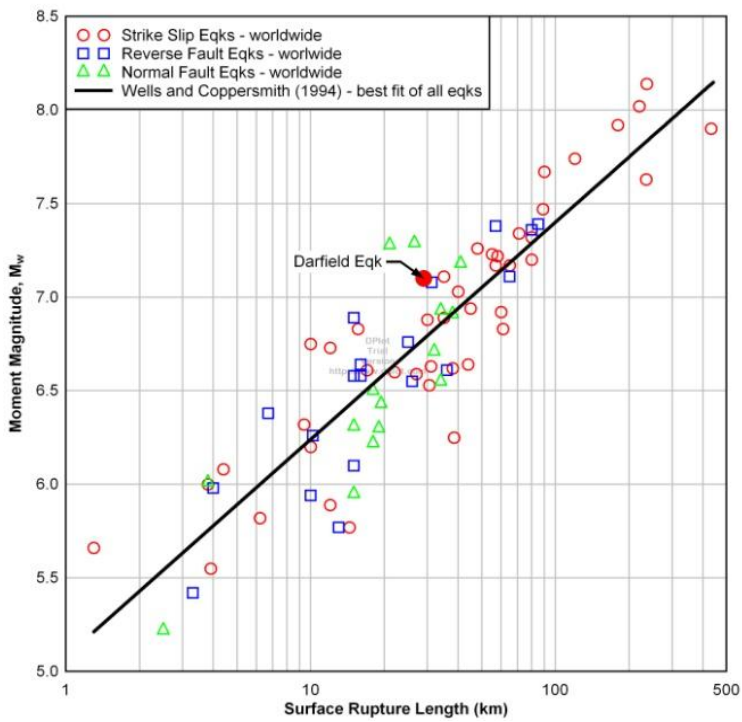

Figure 2.5: $\quad$ Comparison of surface rupture length (SRL) for the Darfield earthquake with global fault data compiled by Wells and Coppersmith (1994). (Global fault data courtesy of Don Wells). 
Vertical offsets of up to $\sim 1 \mathrm{~m}$ occur at constraining or releasing bends. Oblique east-side down slip on the NWstriking western portion of the fault resulted in partial diversion of the Hororata River. The gross morphology of the fault is that of a series of E-W striking, NE-stepping surface traces that in detail consist of ESE-trending Riedel fractures with right-lateral displacements, SE-trending extensional fractures, SSE- to S-trending Riedel' fractures with left-lateral displacements, and NE-striking thrusts and folds. Offsets as small as $10-50 \mathrm{~mm}$ were able to be mapped due to the numerous straight features (e.g., roads, fences) crossing the fault. As a consequence, the Greendale fault surface rupture length (SRL) has been measured to a high level of confidence. However, when the SRL is plotted against Moment Magnitude $\left(\mathrm{M}_{\mathrm{w}}\right)$, and compared to global fault data (Figure 2.5), the Greendale SRL seems remarkably short for an earthquake of $\mathrm{M}_{\mathrm{w}}$ 7.1. This is likely because much of the fault rupture occurred beneath the surface without any clear surface topographic expression. An ENE trending, $\geq 6 \mathrm{~km}$ long line of broken fences and roads $\sim 2 \mathrm{~km}$ south of Prebbleton indicates that the rupture process may have been complex and involved additional faults; this hypothesis is currently being tested with further geological mapping and shallow crustal geophysics. The eastern end of the fault north of Rolleston is undergoing creep at the surface, suggesting that the subsurface extent of the Greendale Fault rupture may extend further to the east then the mapped surface rupture. There is no seismological evidence to support the continuation of the fault into Christchurch City and post-earthquake creep along faults is an expected and well documented phenomenon. Ongoing research and mapping of deformation throughout the region will provide additional constraints on the spatial pattern of surface rupture.

\subsection{History of the Greendale fault}

Given the E-W strike of the Greendale Fault, it is very likely that this fault first formed during crustal extension more than 50 to 60 million years ago, when the shape of New Zealand (aka Zealandia) was much different from today. The Greendale Fault ruptured primarily across alluvial plains of the 'Burnham' surface, abandoned by rivers at the end of the Last Glaciation (Forsyth et al. 2008). No evidence of previous faulting had been recognized, either prior to the earthquake or in retrospective examination of pre-earthquake aerial photographs. However, thorough cultivation of the Canterbury Plains following the arrival of Europeans in the mid 1800s, some detail of the original river channel form has been subdued. Vertical offset along much of the new fault trace was minimal, given the strike-slip dominated movement, it is probable that previous earthquakes had small vertical-tolateral displacements that would have evolved with time into isolated small hills that would not be easily recognizable as fault scarps. It is also possible that previous earthquakes did not produce surface rupture, as was the case for the $2010 \mathrm{M}_{\mathrm{w}}$ 7.0 Haiti earthquake, which shows no evidence for faulting at the surface. For these reasons, it is important to be cautious when drawing conclusions on the long term earthquake history of the Greendale Fault based on aerial photographs. Future research into 'paleo-liquefaction' features and fault trenching will hopefully yield datasets relevant to understanding the long-term history of this fault. Other, possibly analogous faults (e.g., Bobby's Creek Fault, Ashley Fault) have Holocene earthquake recurrence intervals ranging from 1,0004,000 yrs.

\subsection{Geomorphology of Soil Deposits in the Christchurch Area}

The Canterbury Plains, about $160 \mathrm{~km}$ long and of varying width, are New Zealand's largest areas of flat land. The plains have been formed by the overlapping fans of glacier-fed rivers originating from the Southern Alps. The plains are often described as fertile, but the soils are variable. Most are derived from the greywacke of the mountains or from loess (fine sediment blown from riverbeds). In addition, clay and volcanic rock are present near Christchurch from the Port Hills slopes of the Banks Peninsula.

The city of Christchurch is located at the coast of the Canterbury Plains adjacent to an extinct volcanic complex forming Banks Peninsula. Most of the city was developed on swamp, beach dune sand, estuaries and lagoons, which have now been drained (Brown et al., 1995). The two main rivers, Avon and Heathcote, which originate from springs in western Christchurch, meander through the city and act as main drainage system. The Waimakariri River with its catchment in the Southern Alps, regularly flooded Christchurch prior to stopbank construction and river realignment, which began shortly after the city was established in 1850 .

Of particular relevance to the liquefaction and lateral spreading that occurred during the Darfield earthquake are the locations of the abandoned/old river channels of the Waimakariri River. The area surrounding Kaiapoi as it exists today is shown in Figure 2.6. The main branch of the Waimakariri River flows from the west to the east, curving northwards as it passes beneath the town of Kaiapoi. A network of stop banks has been constructed to constrain the flow of the river. The Kaiapoi River runs through the centre of Kaiapoi and is a tributary to the Waimakariri River. However, as discussed below, the Kaiapoi River used to be a branch of the Waimakariri River.

The area shown in Figure 2.6 is also shown in Figure 2.7, as it existed in 1935. The differences in the river channels from 1935 and the present have been highlighted. The red dashed line represents the current position of the Waimakariri River, showing that there has been little movement between 1935 and today. However, two differences in the locations of the river channels are highlighted in red and green in Figure 2.7. The red zone highlights an old river bed that is south of the Waimakariri River and that runs in a north-easterly direction, connecting to the Waimakariri River. A man-made channel diverts the flow of the Waimakariri River from the old bed. The green shaded region highlights the course of the old north branch of the Waimakariri River that used to flow around the western side of Kaiapoi, joining up with the present day Kaiapoi River in the centre of town. Finally, at the mouth of the Waimakariri River, the differences in sand bar characteristics in 1935 and today are highlighted in blue. Today the Waimakariri River empties into the ocean north of where it did in 1935, with sand bars extending from both the north and the south in 1935 .

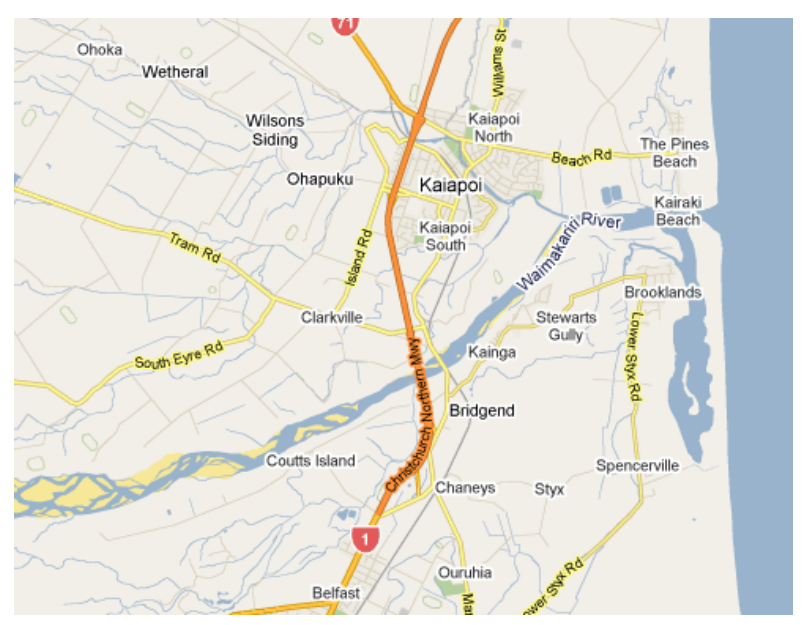

Figure 2.6: Kaiapoi and vicinity, present day (Google Inc. 2010). 


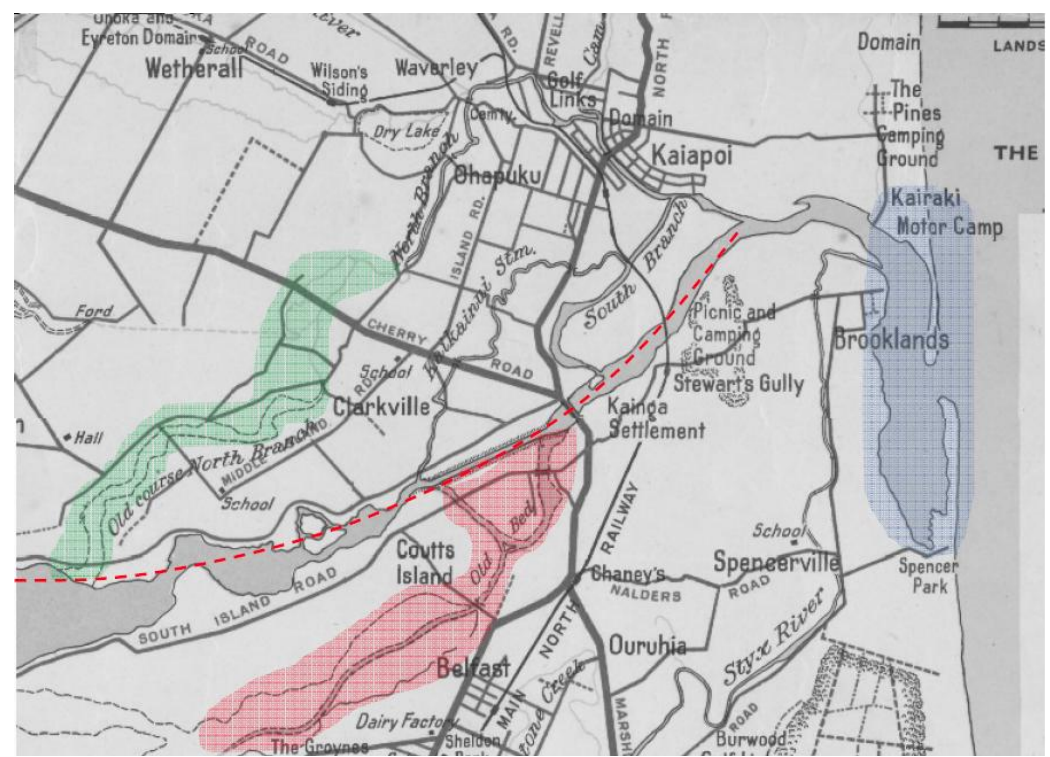

Figure 2.7: Kaiapoi and vicinity, 1935. (Image from Christchurch City Libraries; Shell NZ, 1935).

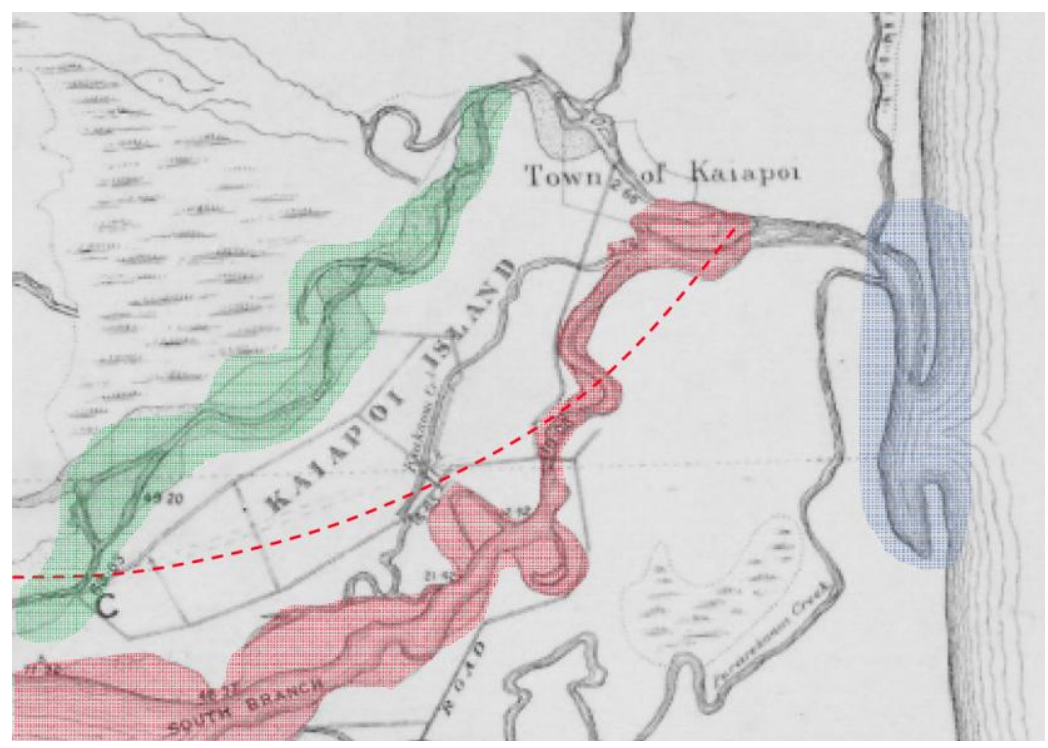

Figure 2.8: $\quad$ Kaiapoi and vicinity, 1865. (Ward \& Reeves, 1865).

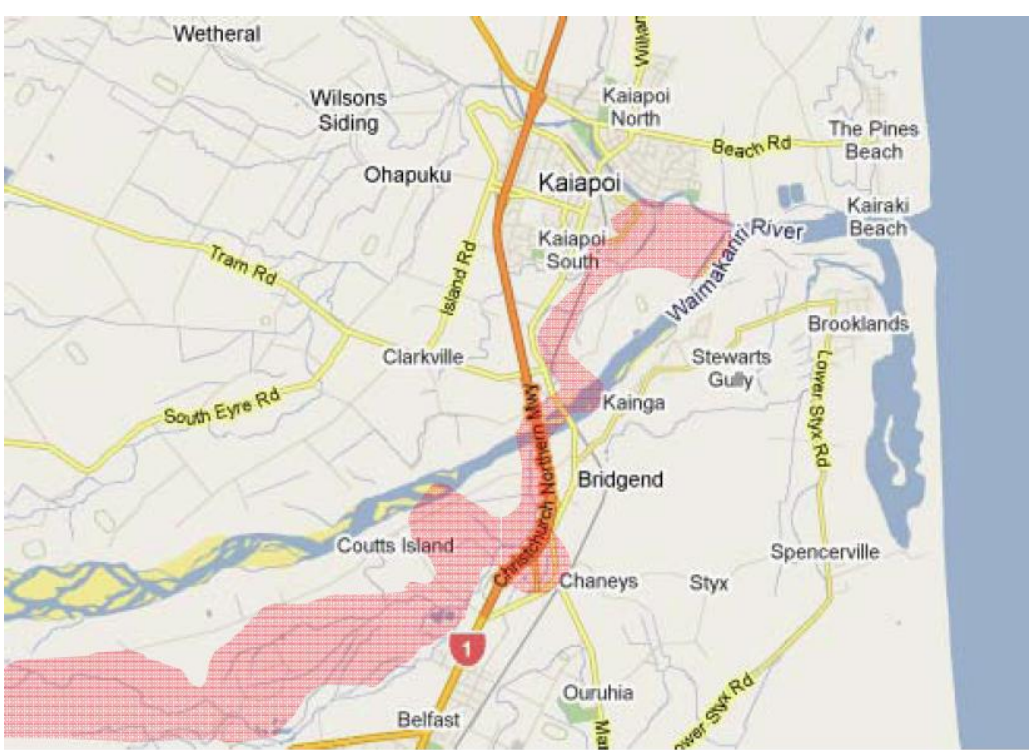

Figure 2.9: $\quad$ Present day Kaiapoi with position of 1865 river channel highlighted in red. (Google Inc. 2010). 
The 1865 position of the south branch of the Waimakariri River is superimposed onto the present day map of the region in Figure 2.9. The old channel covers a large area on the eastern side of South Kaiapoi, coming from the south along the present-day railway line. South of the present-day Waimakariri River, the old channel covers a large part of the Coutts Island area on both sides of State Highway 1, extending west across farms and golf courses on the landside of the present day stopbanks. The implications of the location of the old river channel on the observed liquefaction and lateral spreading that occurred during Darfield Earthquake are discussed in subsequent chapters.

\section{SEISMOLOGICAL ASPECTS}

\subsection{Regional seismicity and historical earthquakes}

New Zealand straddles the boundary of the Australian and Pacific plates, where relative plate motion is obliquely convergent across the plate boundary at about $50 \mathrm{~mm} / \mathrm{yr}$ in the north of the country, $40 \mathrm{~mm} / \mathrm{yr}$ in the centre, and $30 \mathrm{~mm} / \mathrm{yr}$ in the south (DeMets et al. 1994). The complex faulting associated with the changing orientation of the subduction zones in the northeast and southwest, causes predominantly dextral faulting through the axial tectonic belt in the centre of the country.

As a result of this complex faulting, New Zealand is a region of distributed seismicity, in that the relative movement of the Australian and Pacific plates are not accommodated by one or two faults in a narrow zone, but by many faults across a much wider zone (the axial tectonic belt). It is therefore not surprising to observe that both large historical earthquakes (Figure 3.1a), and recent seismicity (Figure 3.1b) can occur in almost any region in New Zealand.

\subsection{Finite fault models}

Finite fault models for the Darfield earthquake have been developed by several different organizations. Two publicly available inversions from USGS and ERI are shown in Figure 3.2 and Figure 3.3. Given that finite fault inversions are illconditioned, as expected, there are some differences between the models. However, both models illustrate that the nucleation point was approximately at the centre of the ruptured fault plane. The resulting bi-lateral rupture therefore would have resulted in notably shorter duration of intense ground shaking at various locations, than would have occurred if the fault had have ruptured in a uni-lateral fashion. Both finite fault models also indicate one large asperity of high slip to the west of the epicentre. This is likely to have resulted in forward directivity effects observed in ground motions to the west of the fault, and backward directivity effects to the east of the fault (i.e. Christchurch).

\section{Large New Zealand Earthquakes}
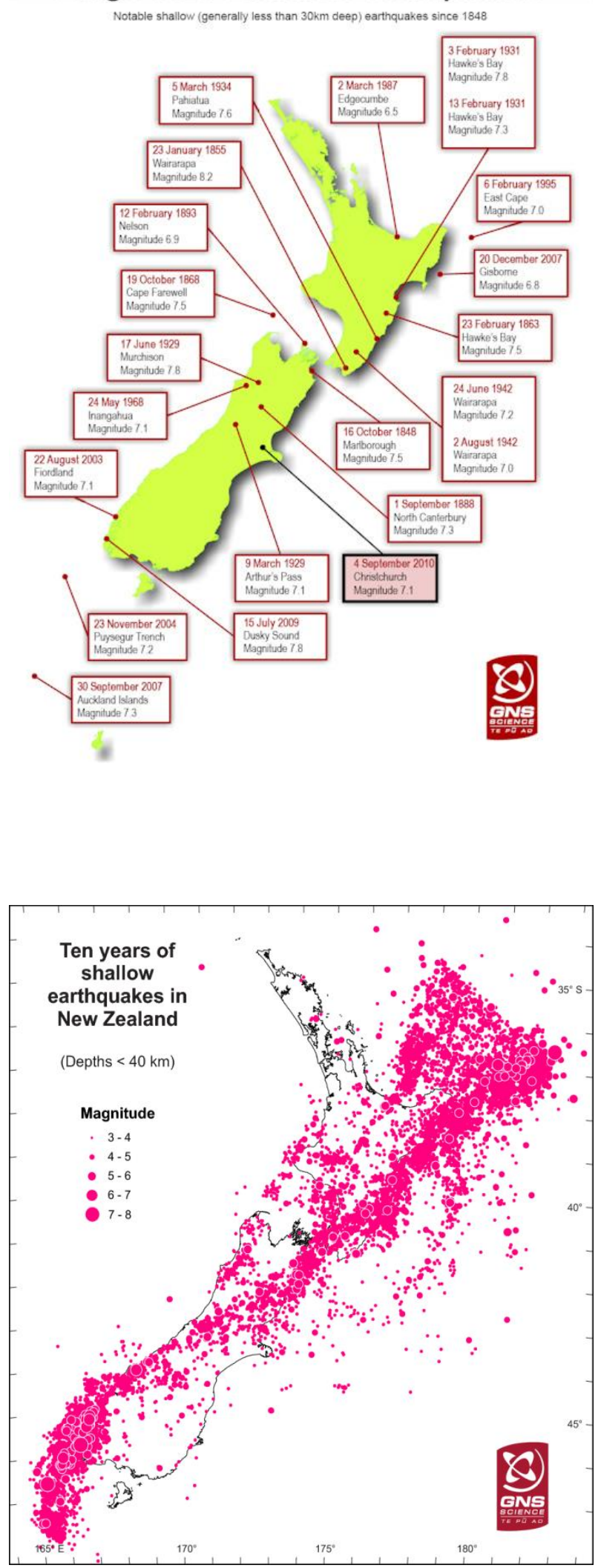

Figure 3.1: (a) Historical large earthquakes in New Zealand.(http://sylph.gns.cri.nz/what/earthact learthquakes/historic.html) and

(b) shallow seismicity in the last ten years. (http://www.geonet.org.nz/earthquake/) 

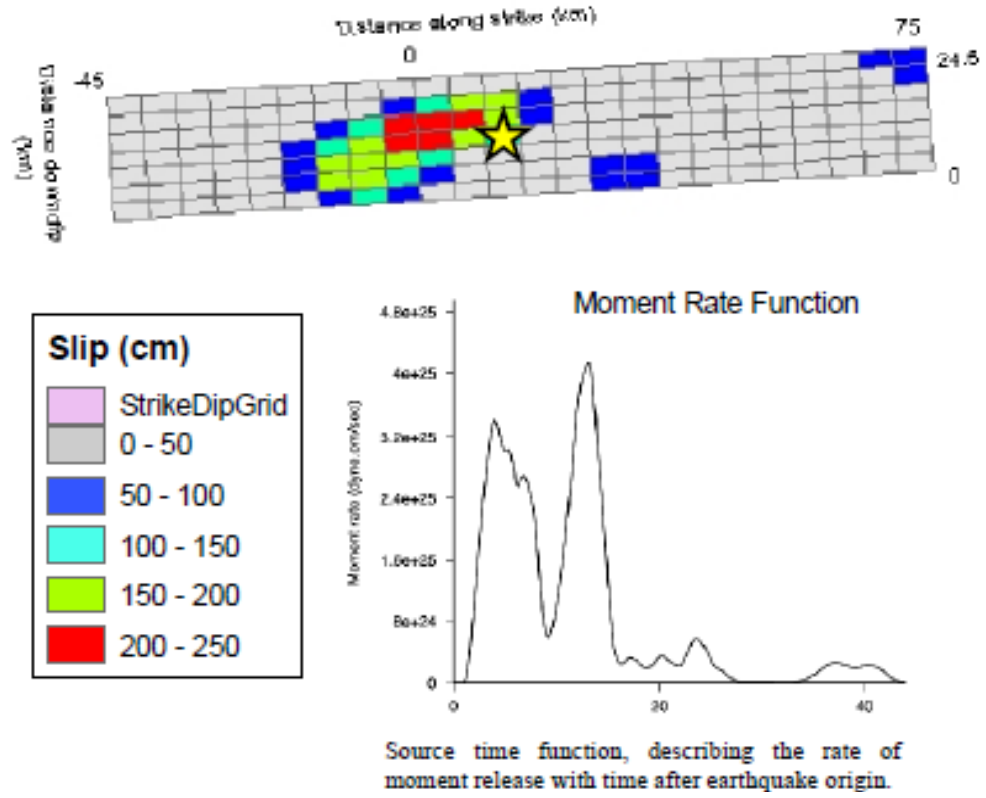

Figure 3.2: $\quad$ Finite fault inversion from Gavin Haynes (USGS). (http://earthquake.usgs.gov/earthquakes/eqinthenews/2010/us2010atbj/finite_fault.php)

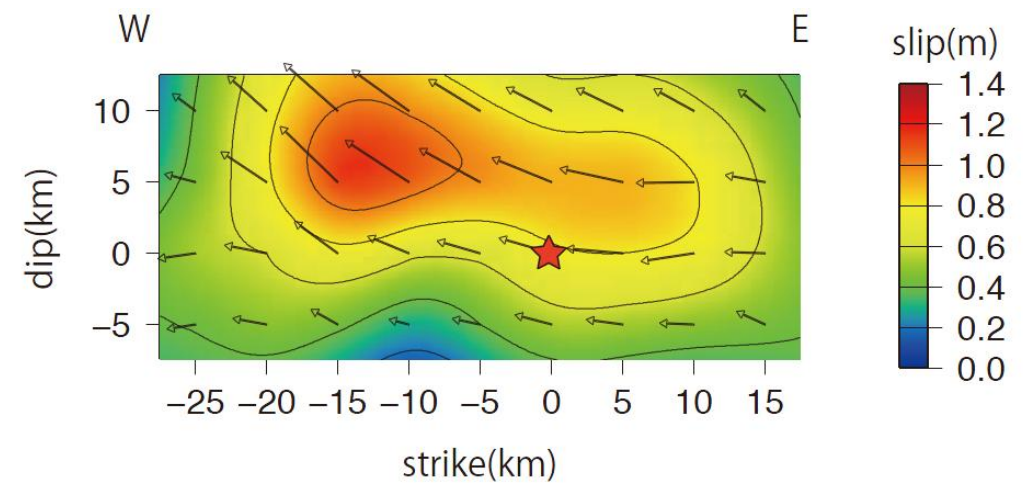

Figure 3.3 Finite fault inversion from ERI. (http://outreach.eri.u-tokyo.ac.jp/2010/09/201009_nz_eng/)

\subsection{Rupture dimensions and aftershocks}

Geologists initially mapped the surface trace of the Greendale fault as $22 \mathrm{~km}$, but further work has found that now there is 29 $\mathrm{km}$ of surface expression. As indicated by the finite fault models discussed in the previous chapter, the length of the fault rupture at depth is likely to be on the order of $40 \mathrm{~km}$.

There have been numerous aftershocks recorded since the $\mathrm{M}_{\mathrm{w}} 7.1$ mainshock. Figure 3.4 illustrates that the temporal occurrence of aftershocks has been in line with statistical predictions.

The distribution of earthquakes observed in the Canterbury region over the period 24 July - 24 September, which are primarily the result of the $\mathrm{M}_{\mathrm{w}} 7.1$ mainshock and its aftershocks is illustrated in Figure 3.5. The $\mathrm{M}_{\mathrm{w}} 7.1$ mainshock has triggered many aftershocks on the edges of the Greendale Fault, but also on many smaller faults in the general region. Although there is some speculation, it is generally considered that the occurrence of the $\mathrm{M}_{\mathrm{w}} 7.1$ mainshock will result in little stress transfer effects to the primary faults in the axial tectonic belt (such as the Alpine fault).

\subsection{Ground motion shaking}

The ground motion shaking as a result of the mainshock was widely felt in the Canterbury region, and in New Zealand in general. Figure 3.6 illustrates the distribution of "felt-it" reports that were submitted online by the public. Figure 3.7 illustrates the USGS ShakeMap, which utilizes both predictive models of MMI, and also the publicly submitted "felt-it" report. It can be seen that MMI VIII-IX was observed in Darfield and Rolleston townships, and that the wider Christchurch region generally experienced MMI VI-VII.

Numerous people and authorities have contrasted the Darfield earthquake with the Haiti earthquake as an illustration of how adequate building standards and preparedness can lead to a large difference in damage and casualties. However, comparison of MMI's observed to population exposures in Canterbury and Haiti dictates that caution should be made in such an interpretation (http://dotearth.blogs.nytimes.com/2010/09/07/in-earthquakespoverty-population-and-motion-matter/). 

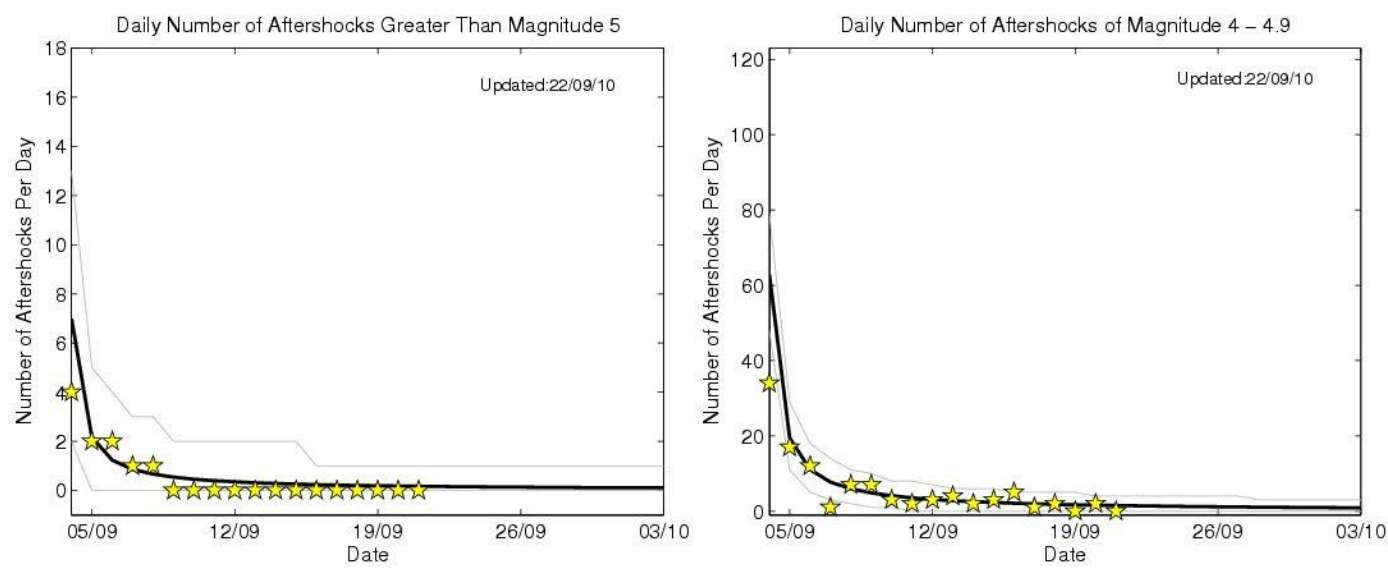

Figure 3.4: $\quad$ Number of aftershocks with: (a) magnitude greater than 5; and (b) magnitude between 4 and 5, in comparison with statistical aftershock models. (http://www.geonet.org.nz/news/sep-2010-darfield-earthquake/gns-scienceresponse.html)

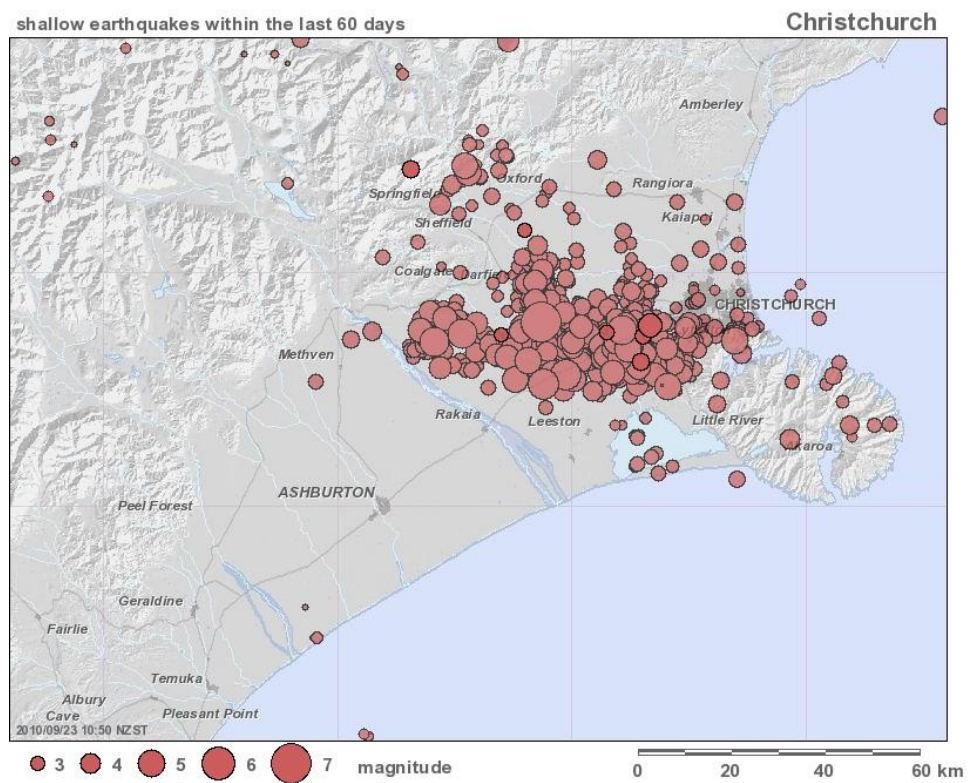

Figure 3.5: $\quad$ Location of earthquakes in the Canterbury region over the period 25 July-24 September 2010 (i.e. primarily the mainshock and its aftershocks). (http://images.geonet.org.nz/maps/quakes/262-christchurch-quake.jpg)

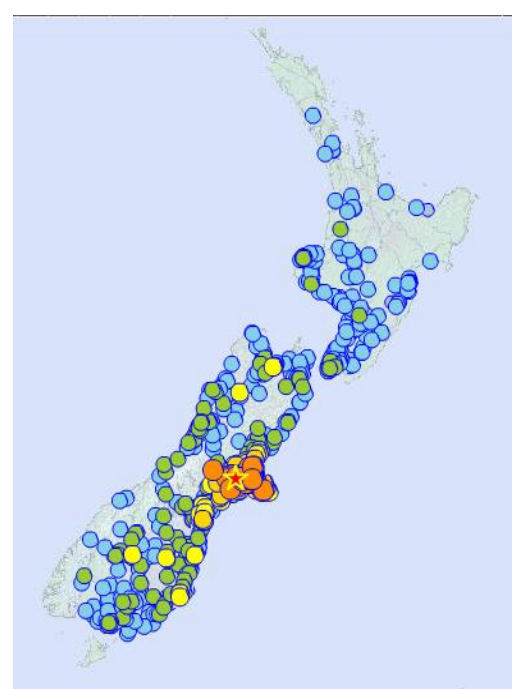

Figure 3.6: Locations of "felt-it" reports submitted online, there were 6,897 reports as of 24 September 2010. (http://www.geonet.org.nz/earthquake/quakes/3366146g-shaking.html) 


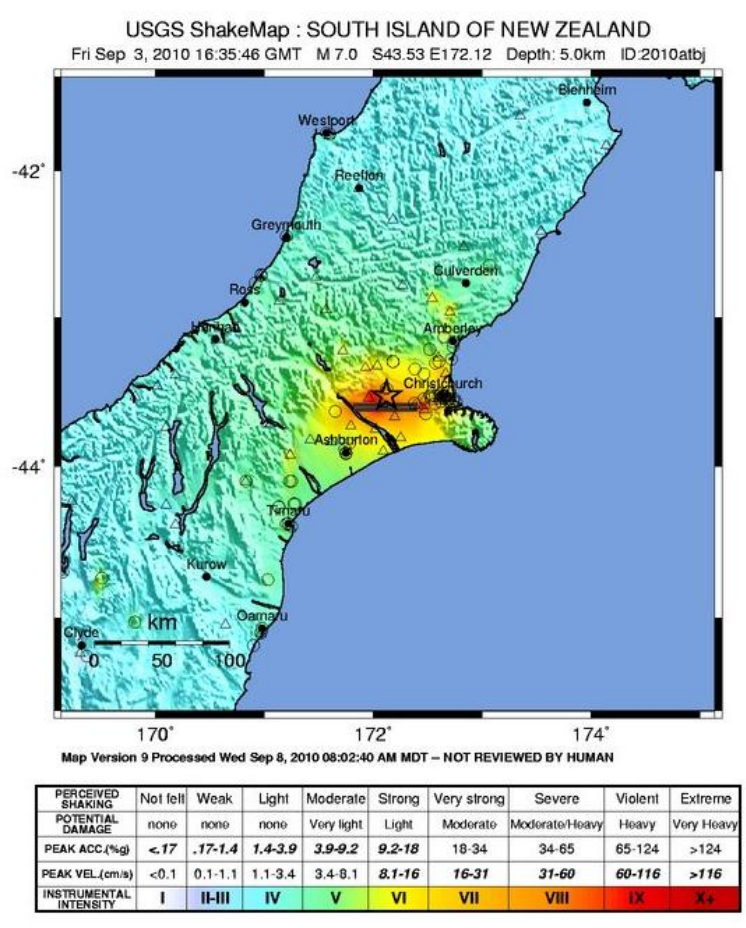

Figure 3.7: $\quad$ USGS ShakeMap from the $M_{w} 7.1$ mainshock. (http://earthquake.usgs.gov/earthquakes/shak emap/global/shake/2010atbj/)

The Canterbury region is well instrumented with seismographs that can record strong ground motion. Figure 3.8 illustrates the (vector-maximum) peak ground accelerations that were recorded throughout the region. In the near source region, it can be seen that there are five recordings above $0.7 \mathrm{~g}$ (although many of these peaks are in the vertical component). The maximum $1.25 \mathrm{~g}$ recorded at the Greendale station has also been deemed to have been contaminated by falling debris in the house garage in which the seismograph is installed (J. Zhao, personal communication).
Using a wavelet decomposition procedure (Chanerley and Alexander, 2010) and integrating the Greendale record with and without the anomalous vertical peak at 35 seconds, Andrew Chanerley (pers comm.) finds that the horizontal velocities and displacements ( $\mathrm{x}$-displ. $=-1,631 \mathrm{~mm}$; $\mathrm{y}$-displ. $=-458.6 \mathrm{~mm}$ ) are little affected, with the vertical integrated displacement ranging from $-604.7 \mathrm{~mm}$ to $-664.6 \mathrm{~mm}$. This result suggests that falling debris-induced acceleration spikes will have little effect on structural response computations (themselves integration processes). Further, the integrated permanent "fling" displacements are consistent with the field observations of $3-4 \mathrm{~m}$ offset $(2 \times 1.63 \mathrm{~m}=3.26 \mathrm{~m})$.

Figure 3.9 illustrates a preliminary comparison between the attenuation of ground motion intensity with source-to-site distance. The comparison is preliminary in that, as previously mentioned, many details of the fault rupture (i.e. the fault plane and faulting mechanism) have not been finalised. Acceleration Spectrum Intensity (ASI), defined as the integral of the pseudospectral acceleration of a ground motion from 0.1 to $0.5 \mathrm{sec}$ (Von Thun et al. 1988), shown in Figure 3.9a illustrates somewhat of a high-frequency average of a ground motion, while Spectrum Intensity (SI), defined as the integral of pseudospectral velocity of a ground motion from 0.1 to 2.5 sec (Housner 1952), shown in Figure 3.9b illustrates a moderate frequency average of a ground motion. It can be seen that the ground motions from this event by and large conform to predictions from empirical ground motion prediction equations. There is however, clear variability in the motion amplitudes that occur as a result of near-source effects, topography and basin effects, and near-surface nonlinearities in the soft fluvial deposited soils that underlie the Christchurch region.

Figure 3.10, Figure 3.11, and Figure 3.12 illustrate the recorded acceleration time histories and respective response spectra at the Greendale, Christchurch hospital, and Kaiapoi strong-motion stations. Also shown for reference are the predicted response spectra from ground motion prediction equations (Brendon Bradley, pers. comm.). Locations of these seismographs can be found at:

http://www.geonet.org.nz/resources/network/netmap.html.

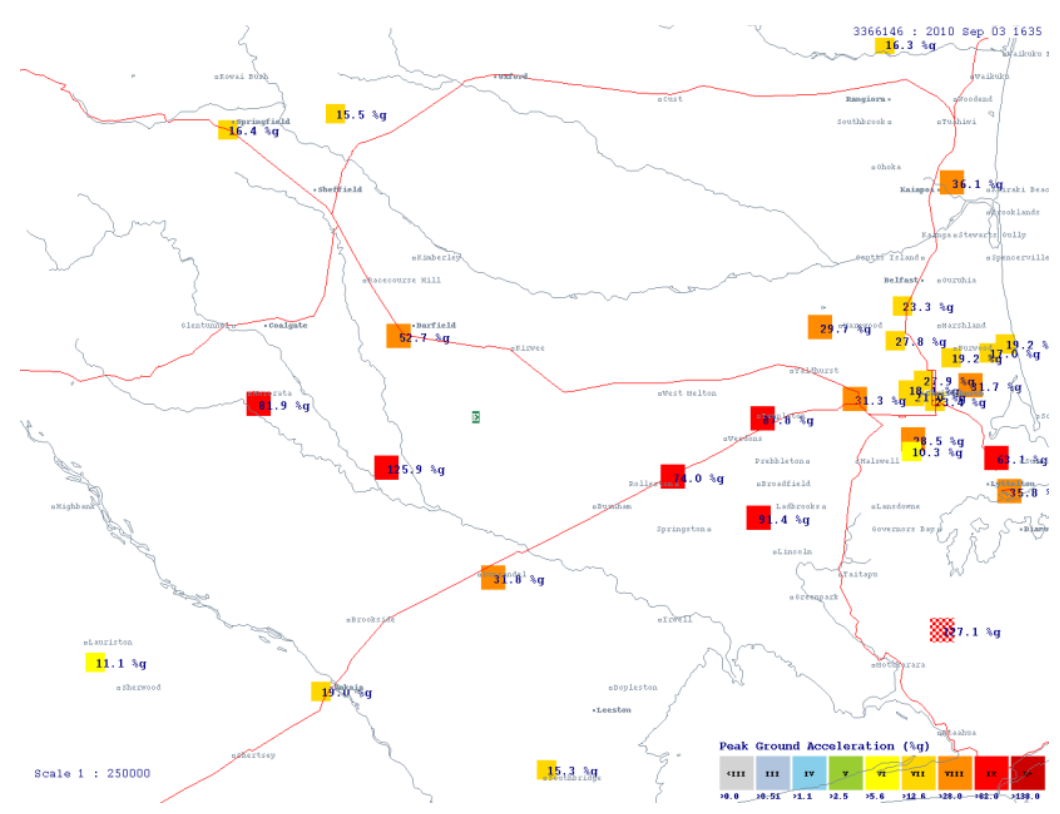

Figure 3.8: Vector-maximum peak ground accelerations observed in the Canterbury region from strong motion seismometers. (http://www.geonet.org.nz/news/sep-2010-darfield-earthquake/gns-science-response.html) 

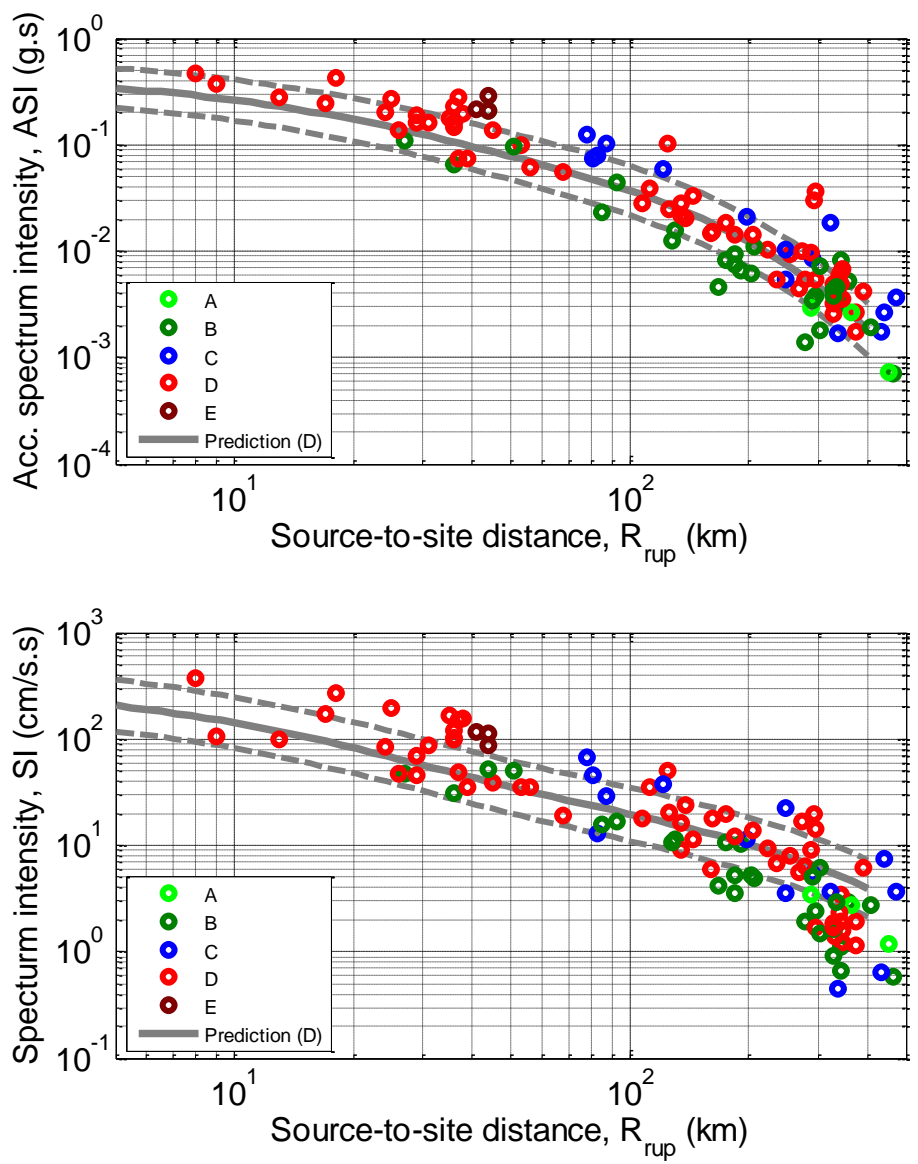

Figure 3.9: $\quad$ Observations of ground motion intensity compared with empirical prediction equations. The predictive relation for ASI and SI are a NZ-specific modification of the Chiou and Youngs (2008) model (Brendon Bradley, pers. comm.).
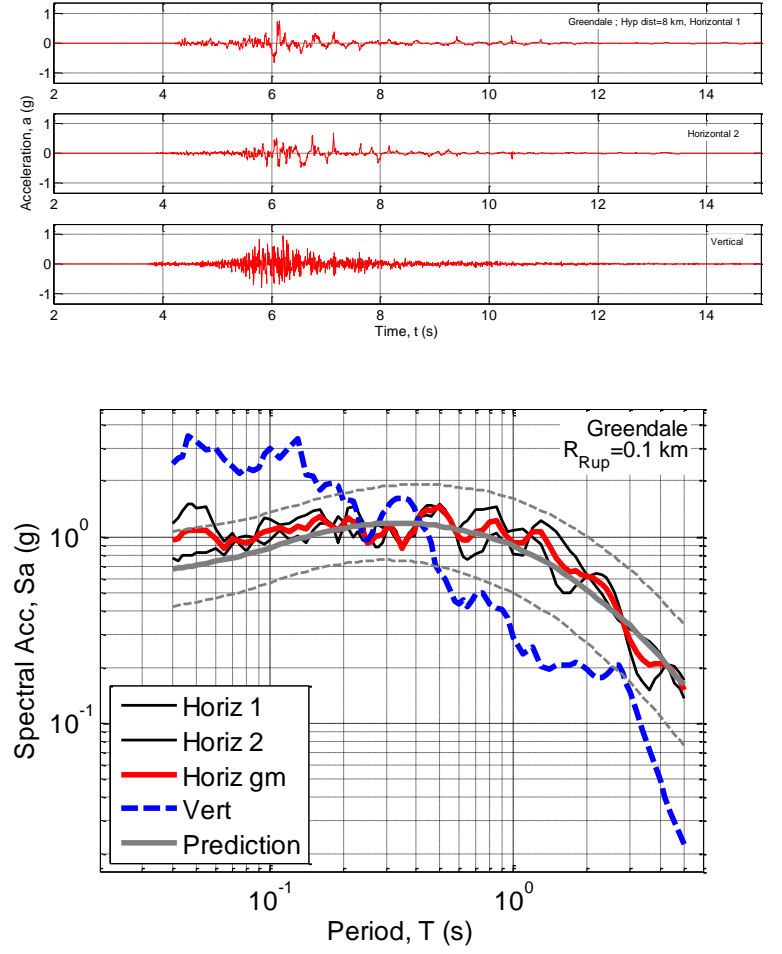

Figure 3.10: (a) Acceleration time-histories; (b) response spectra at Greendale seismograph. (Note that "Horiz $\mathrm{gm}^{\prime}$ is the geometric mean of the two horiziontal components of motion).
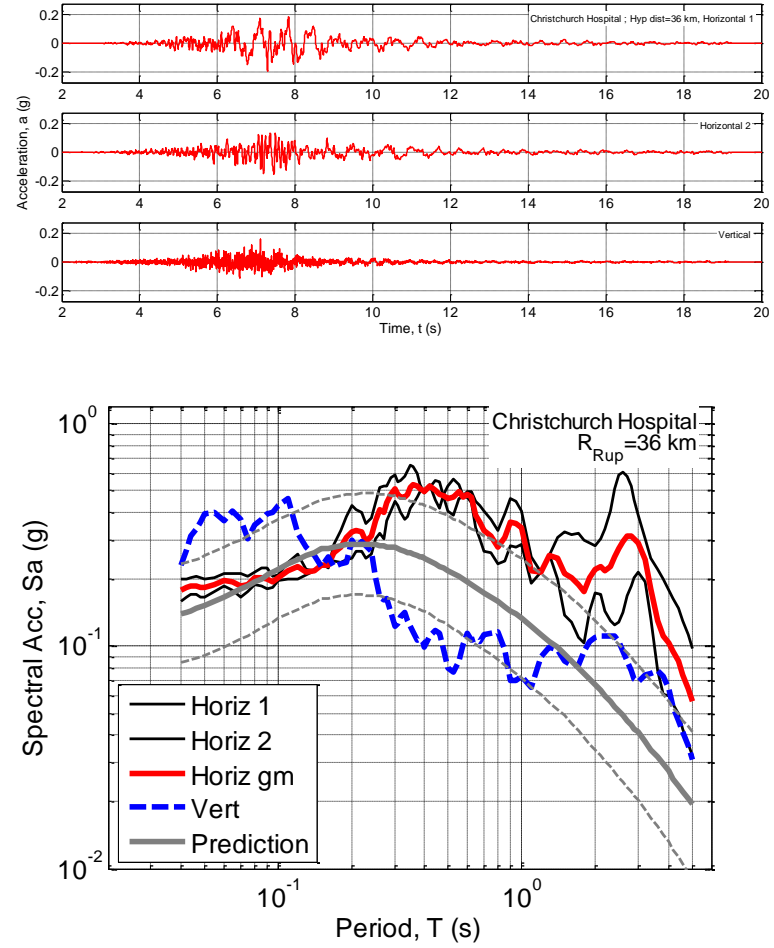

Figure 3.11: (a) Acceleration time-histories; (b) response spectra at Christchurch hospital seismograph. (Note that "Horiz gm" is the geometric mean of the two horiziontal components of motion). 

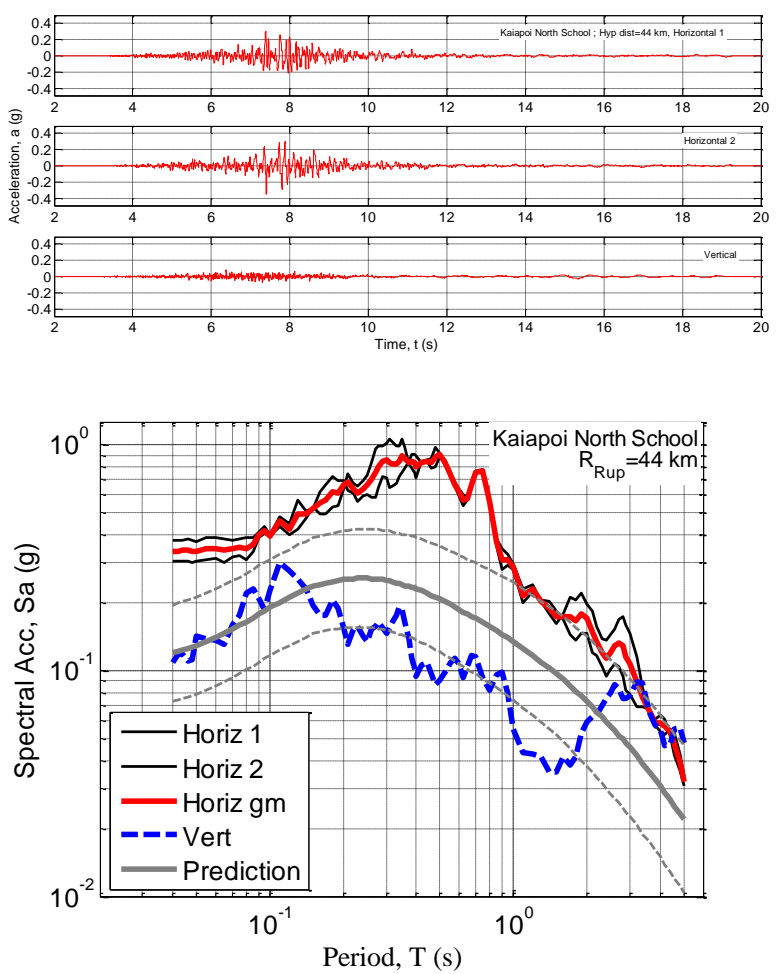

Figure 3.12: (a) Acceleration time-histories; (b) response spectra at Kaiapoi seismograph. (Note that "Horiz gm" is the geometric mean of the two horizontal components of motion.)

The Greendale seismograph was located almost directly over the fault plane and recorded the strongest ground motion from the mainshock. The horizontal components of the ground motion indicate that cyclic mobility in surficial soil layers may have occurred during the strong ground shaking. The occurrence of cyclic mobility is indicated by the high frequency spikes in the later half of the strong motion record. The spectral accelerations for this set of ground motion records are in line with empirical predictions.

The Christchurch hospital seismograph is located near the centre of Christchurch. The response spectra from this station clearly illustrate the significance of basin effects on the spectral amplitudes at 2-3 second vibration periods. Additionally, the spectral peak at $0.3-0.5$ seconds is likely due to the near-surface sediments which were rapidly deposited in the post-glacial period.

The Kaiapoi seismometer is located in the town of Kaiapoi, which experienced substantial liquefaction and lateral spreading. It can be seen that the ground motions observed are generally well above those predicted by empirical models, indicating the importance of near surface sediments on site amplification.

\section{LIQUEFACTION AND LATERAL SPREADING}

In the 2010 Darfield Earthquake widespread liquefaction and lateral spreading occurred in various parts of Christchurch City (most extensively in the suburbs to the east of the city centre, but also in more localised areas to the north and southwest of the city), the town of Kaiapoi and the beachside settlements near the Waimakariri River. The liquefaction and associated ground deformation/failure led to significant damage to residential houses and lifeline systems. Particularly heavy damage was induced by lateral spreading, which was very extensive and severe in areas of South Kaiapoi
(Courtenay Dr), and very severe but localized in some areas of Bexley, Spencerville and North Kaiapoi. Along the meandering loops of the Avon River in Avonside and Dallington, post-liquefaction settlement and lateral spreading was widespread, but lateral displacements were relatively moderate. Loose to very loose alluvial fine- to silty sand deposits in areas of old (abandoned) river channels, lagoons, wetlands and near waterways (streams, rivers) were responsible for the widespread liquefaction, lateral spreading and ground failures. In view of the extensiveness and severity of the effects, one may argue that the most significant engineering aspects of the 2010 Darfield Earthquake were geotechnical in nature, with liquefaction and lateral spreading being the principal mechanisms for the inflicted damage.

The observations made by the NZ-GEER reconnaissance team in these areas are briefly described below. The surveys were performed on foot, by car and from a helicopter over a period of six days. A broad-brush field reconnaissance was conducted in the first two days, followed by pin-point investigations at specific locations including detailed site inspections and field testing using: Dynamic Cone Penetration Test (DCPT), Swedish Weight Sounding (SWS), and Spectral Analysis of Surface Waves (SASW). Both DCPT and SWS results correlate to the Standard Penetration Test (SPT) N-values, and the SASW provides the shear wave velocity profiles. The observations from these inspections/in situ tests are also detailed below. Figure 4.1 shows the area of interest and some of the localities.

\subsection{Christchurch}

Christchurch is situated in the middle part of the east coast of South Island. It has a population of about 350,000 (the second largest city in New Zealand) and an urban area that covers approximately $450 \mathrm{~km}^{2}$. It is sparsely developed with approximately 150,000 dwellings (predominantly singlestorey houses with a smaller number of two-storey houses) spread across a large area with many parks, natural reserves and recreation grounds. The Central Business District (CBD) is more densely developed with multi-storey buildings and a relatively large number of historic buildings. The epicentre of the 2010 Darfield Earthquake was located approximately 40 $\mathrm{km}$ west of the Christchurch CBD.

\subsection{Local geology and liquefaction hazard}

The city of Christchurch is located on Holocene deposits of the Canterbury Plains, except for its southern edge, which is located on the slopes of the Port Hills of the Banks Peninsula. The river floodplain and the loess sediments of the Port Hills are the dominant geomorphic features of the Christchurch urban area.

The Canterbury Plains are complex fans deposited by eastward-flowing rivers from the Southern Alps to the Pegasus Bay coast. The fan surfaces cover an area $50 \mathrm{~km}$ wide by 160 $\mathrm{km}$ long. At Christchurch, surface postglacial sediments have a thickness between 15 and $40 \mathrm{~m}$ and overlie 300-400 m thick inter-layered gravelly formations (Brown and Webber, 1992). The surface sediments are either fluvial gravels, sands and silts (Springston formation, with a maximum thickness of 20 $\mathrm{m}$ to the west of Christchurch) or estuarine, lagoon, beach, and coastal swamp deposits of sand, silt, clay and peat (Christchurch formation, with a maximum thickness of $40 \mathrm{~m}$ at New Brighton coast, east of CBD). The soil deposits at relatively shallow depths of up to $15-20 \mathrm{~m}$ vary significantly within short distances, both horizontally and vertically.

Brown and Weeber (1992) describe the original site conditions and development of Christchurch as follows: "Originally the site of Christchurch was mainly swamp lying 

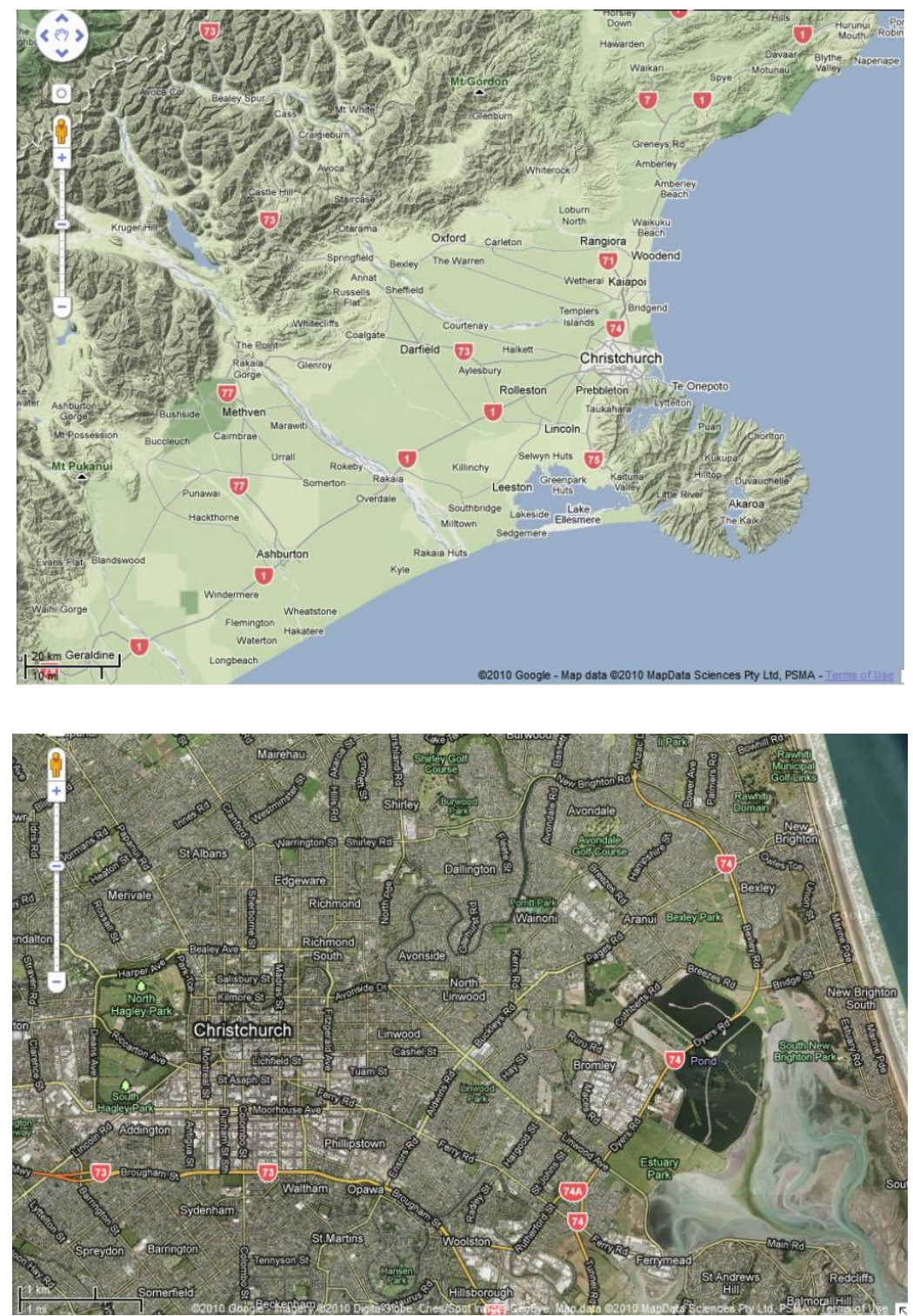

Figure 4.1: Canterbury region, CBD and eastern suburbs of Christchurch (Google Inc. 2010).

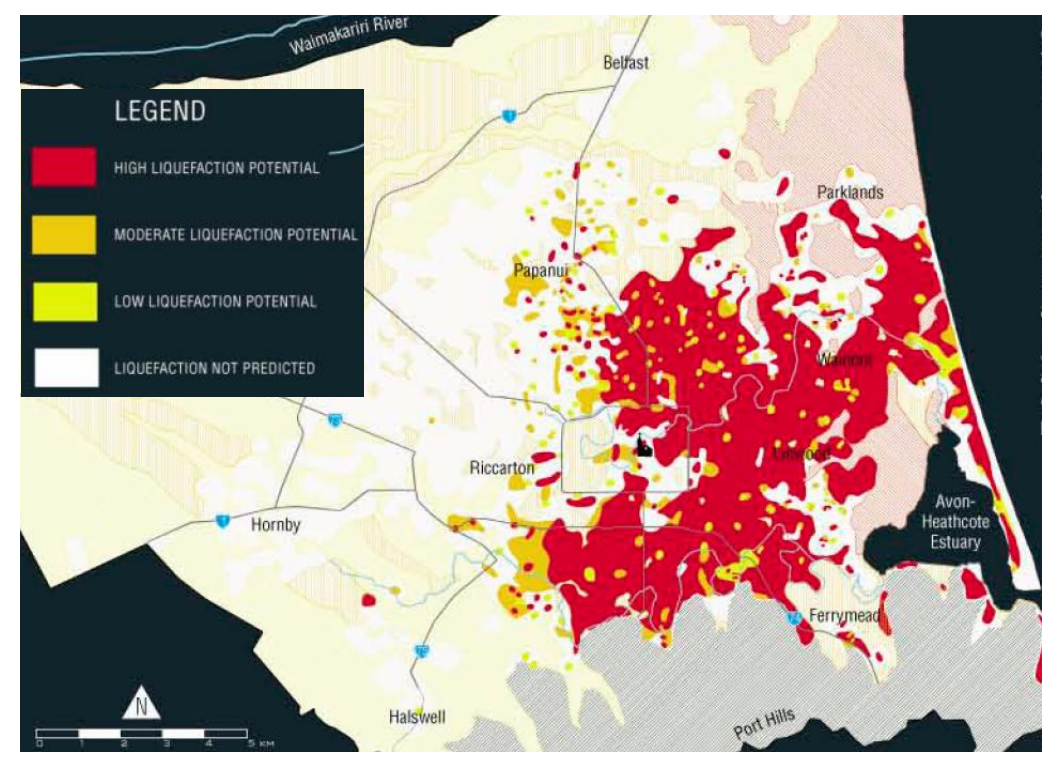

Figure 4.2: $\quad$ High ground-water table liquefaction potential hazard map for Christchurch.

(http://ecan.govt.nz/publications/General/solid-facts-christchurch-liquefaction.pdf; pre-event information provided to residents and public by ECan). 
behind beach dune sand; estuaries and lagoons, and gravel, sand and silt of river channel and flood deposits of the coastal Waimakariri River flood plain. The Waimakariri River regularly flooded Christchurch prior to stopbank construction and river realignment. Since European settlement in the 1850s, extensive drainage and infilling of swamps has been undertaken." Brown and Webber also state that surface deposits are actively accumulating and that the present day river channel deposits are excluded from the above-mentioned Christchurch and Springston formations.

Canterbury has an abundant water supply through openchannels (rivers, streams) and very rich aquifers. The dominant features of present day Christchurch are the Avon and Heathcote rivers that originate from springs in western Christchurch, meander through the city, and feed the estuary at the southeast end of the city. The ground water table is deepest at the west end of the city (at about $5 \mathrm{~m}$ depth), gradually increases heading east, and approaches the ground surface near the coastline. The water table is within $1.0-1.5 \mathrm{~m}$ of the ground surface for most of the city east of the CBD.

The high liquefaction hazard in Christchurch was known prior to the earthquake, as illustrated by the liquefaction hazard map (Figure 4.2) and information provided by the Environment Canterbury (ECan: http://ecan.govt.nz/publications/General/ solid-facts-christchurch-liquefaction.pdf) to residents, based on a study from 2004.

\subsection{Liquefaction manifestation during the Darfield earthquake}

The Darfield Earthquake caused widespread liquefaction in the eastern suburbs of Christchurch along the Avon River, particularly in Avonside, Dallington, Burwood and Bexley. Other suburbs, particularly to the east and northeast of CBD, were also affected by liquefaction, but to a lesser extent. Widespread liquefaction also occurred in Halswell, at the southwest end of the city. Pockets of limited or partial liquefaction were observed in various parts of Christchurch, though these were much fewer to the west of CBD. Figure 4.3 shows areas of observed liquefaction in the urban area of Christchurch based on surface manifestation of liquefaction visible in aerial photographs and initial observations from ground surveying. The areas most severely affected by liquefaction were close to waterways (rivers, streams, swamps). The effects of liquefaction were often localized and changed substantially over a relatively short distance (50-100 m) from very severe to low or no manifestation of liquefaction.

\subsection{Avonside and Dallington}

Widespread liquefaction occurred in Avonside and Dallington, particularly in the areas enclosed within the meandering loops of the Avon River. In these areas, the extensive liquefaction was accompanied by a complex pattern of lateral spreading. Large sand boils adjacent to houses and silty-sand and water covering the streets indicated extensive liquefaction in this area. Ground cracks with complex patterns indicated either lateral spreading features and/or ground distortion due to liquefaction including bearing failures. A large number of residential houses settled, tilted and suffered structural/foundation damage.

Typical manifestation of liquefaction in the backyard of a residential property is shown in Figure 4.4 (Bracken St, Avonside). Sand boil ejecta covered most of the lawn and was about $200 \mathrm{~mm}$ thick in places. There was evidence of massive liquefaction and large surface distortion on Bracken St. The potable water and sewer systems were out of service at the time of the inspections. Despite significant amounts of liquefaction ejecta and broken utilities throughout the neighbourhood, the house shown in the pictures suffered minor damage in terms of differential settlement and cracking.

The geotechnical reconnaissance team performed a detailed survey at St Paul's Church (Gayhurst Rd, Dallington) which suffered damage due to liquefaction in the foundation soils (Chapter 5). Figure 4.5 shows a complex pattern of ground distortion including large cracks and vertical offsets around the building. Extensive sand boils covered the paved area around the building, backyard lawn, and around the perimeter of the building and its foundations. The building suffered large differential settlements and severe structural damage.

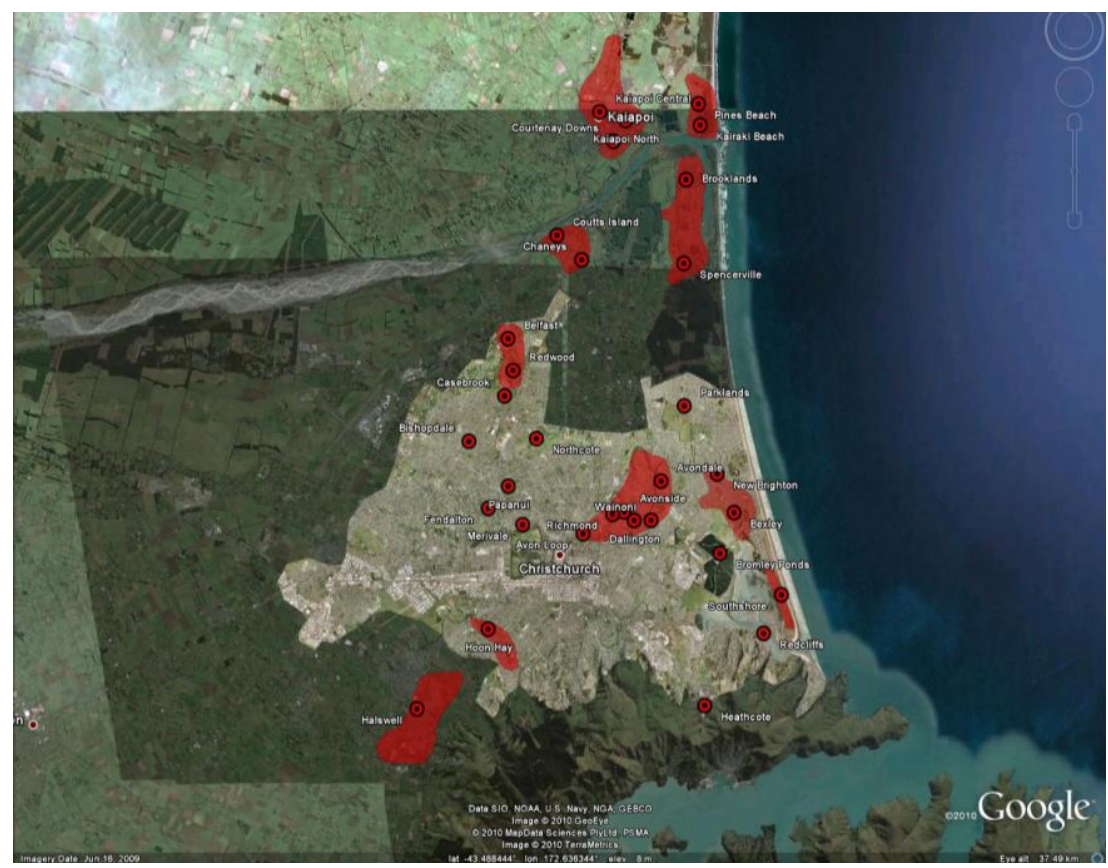

Figure 4.3: $\quad$ Areas of observed liquefaction (red shaded regions and red points) in Christchurch due to the 2010 Darfield earthquake (the liquefaction map is based on surface manifestation of liquefaction visible in aerial photographs and compiled evidence from ground surveying). 

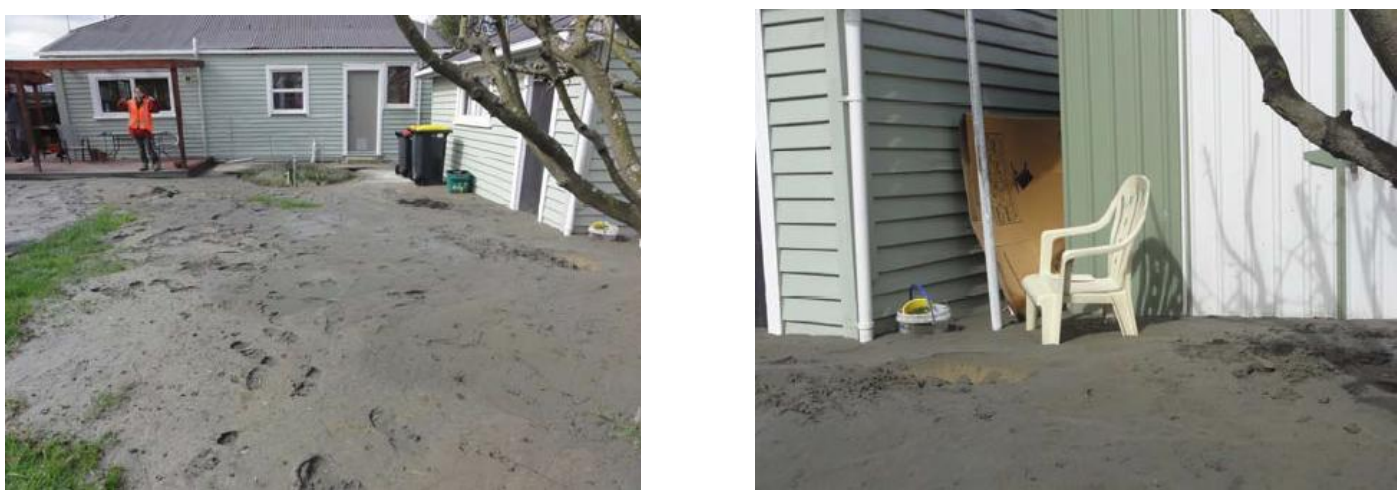

(a) Large sand boils in residential area of Avonside (Bracken St).
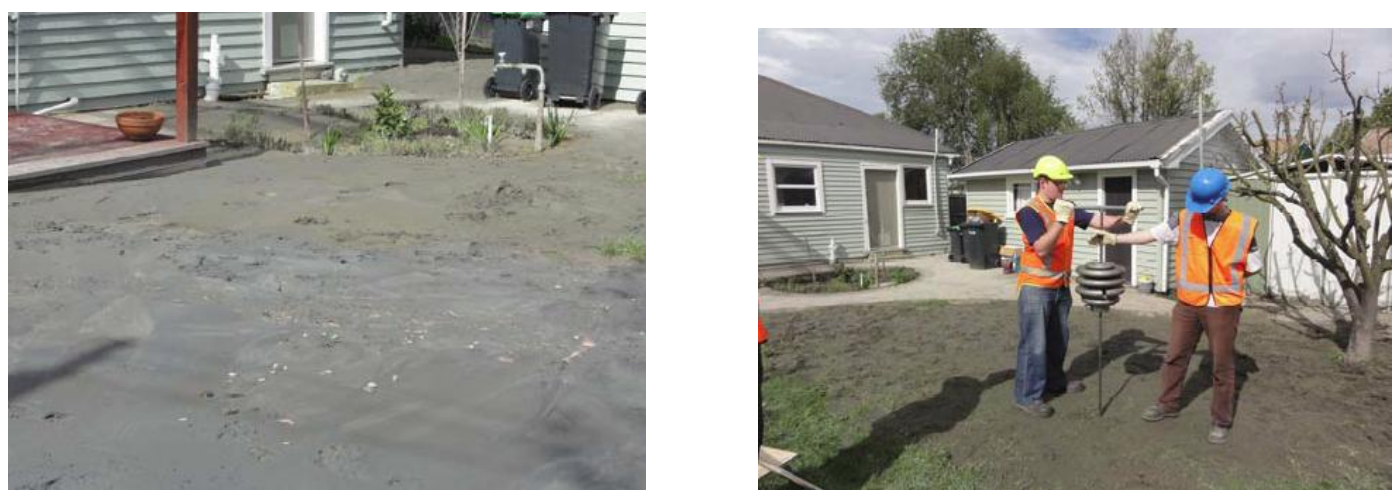

(b) The sand boil (grey non-plastic silty sand) in the bottom half of the photo to the left was typical of many locations across Christchurch and Kaiapoi where massive liquefaction was observed; at this location, a brown silty sand was also found on the ground surface (upper half of the sand boil); photo to the right: University of Canterbury postgraduate students perform Swedish Weight Sounding (SWS) test (Bracken St).

Figure 4.4: $\quad$ Evidence of extensive liquefaction in residential areas of Avonside.

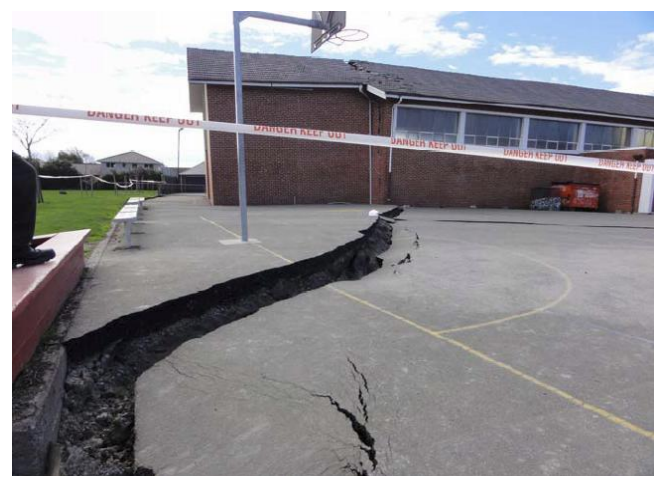

(a) Bearing failure in liquefied soils (St Paul's Church, Dallington); the crack is 500-900 $\mathrm{mm}$ wide with a vertical offset of $330 \mathrm{~mm}$, at its maximum.
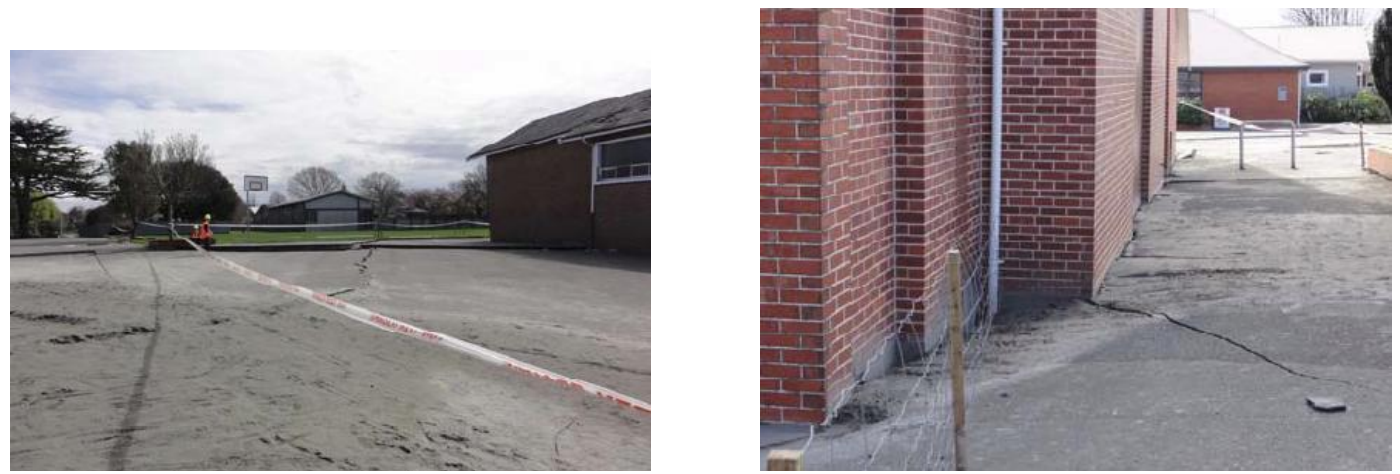

(b) Evidence of liquefaction in foundation soils resulting in large total and differential settlements.

Figure 4.5: $\quad$ Liquefaction-induced bearing failure in Dallington (St Paul's Church, Gayhurst Rd). 
Specifically, the northwest side of the building was ripped in half due to a combination of differential settlement and lateral movement. This site is centrally located in a meandering loop of the Avon River and bounded by the river on all sides at distances of about 150-250 m, except to the north/northeast. There was apparent evidence of lateral spreading in this area, despite being located more than $150 \mathrm{~m}$ from the free-face of the river. (Note, however, that this distance is not necessarily anomalous. Evidence of lateral spreading has been found at distances of up to $2 \mathrm{~km}$ from a free-face in the New Madrid, Missouri, USA, area (Obermeier, S.F., per. comm.). These features manifested during the 1811-1812 earthquakes that occurred in that region.) The tension cracks and fissures around the building were much bigger than those near the river channel, and hence it is possible that they are not directly related only to the lateral spreading. Further investigations are required to clarify these details.

Ten days after the event, the team performed Swedish Weight Sounding (SWS) tests at Bracken St and in the backyard of St Paul's Church. SWS is a simple manually operated penetration test under a dead-load of $100 \mathrm{~kg}$ in which the number of halfrotations required for a $25 \mathrm{~cm}$ penetration of a rod (screw point) is recorded (JIS, 1995). One of the advantages of the SWS test which was heavily utilized in this investigation is the ability to perform the test within a confined space in backyards of residential properties. Figure 4.6 shows the penetration resistance measured in the SWS tests conducted at Bracken St and St Paul's Church, expressed in terms of the number of half-rotations per metre, $N_{S W}$. Correlations exist to transfer this penetration resistance to an equivalent SPT Nvalue. However, the $\mathrm{N}$-value correlations are not presented herein.

Additionally, two Dynamic Cone Penetration Tests (DCPT) were performed at the residence shown in Figure 4.4, one in the backyard and one in the front yard. The results of the DCPTs are shown in Figure 4.7.

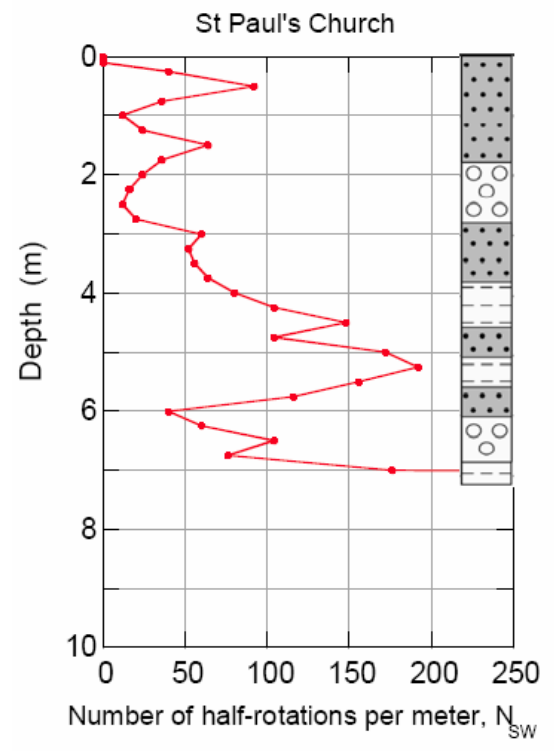

At each of the test locations, a hand auger was used to bore a hole down to the layer that liquefied. This layer was identified by comparing ejecta material with soil extracted by the hand auger. Once at the liquefied layer, the DCPTs were performed until the blow count significantly increased or the team ran out of DCPT rods (i.e., $~ 4.6 \mathrm{~m}$ below the ground surface).

There are several different configurations of the DCPT equipment available. The one used in these investigations was originally designed by Sowers and Hedges (1966) and built by Humboldt Manufacturing Co. This system utilizes a $6.8 \mathrm{~kg}$ mass (15 lb drop weight) on an E-rod slide drive to penetrate an oversized $45^{\circ}$ apex angle cone. The cone is oversized to act as a friction reducer for the rods. The DCPT blow count is the number of drops of the weight required to drive the cone $\sim 45$ $\mathrm{mm}$.

The ground water table at both sounding locations at the Bracken Dr residence was at $\sim 0.8 \mathrm{~m}$, and the top of the liquefiable layer was at a depth of $\sim 2.1$ to $2.4 \mathrm{~m}$. The strata overlying the liquefiable layer were clayey. For one of the tests, the DCPT rods sank under their own weight $200+\mathrm{mm}$, indicating very loose sand. Because no samples are recovered with the DCPT, the thickness of the liquefied sand layer cannot be determined for certain. However, from looking at the results shown in Figure 4.7, the penetration resistance sharply increases at a depth of $\sim 3.5 \mathrm{~m}$. Additionally, there is a very wet, very soft, thin $(\sim 100$ to $150 \mathrm{~mm})$ clay/plastic silt layer that overlies the liquefied layer. It is unknown whether this is a very sensitive material that softens as a result of earthquake shaking and/or sampling or whether it is a result of a water film that formed between the liquefied layer and clay layer.

A DCPT and SASW test were also performed at St Paul's Church. The results of these tests are shown in Figure 4.8. Based on the bore hole augered for the DCPT test, the water table was at a depth of about $2.3 \mathrm{~m}$ and the top of the liquefied layer was at a depth of about $2.8 \mathrm{~m}$. The SASW test was performed approximately $20 \mathrm{~m}$ away from the DCPT location.

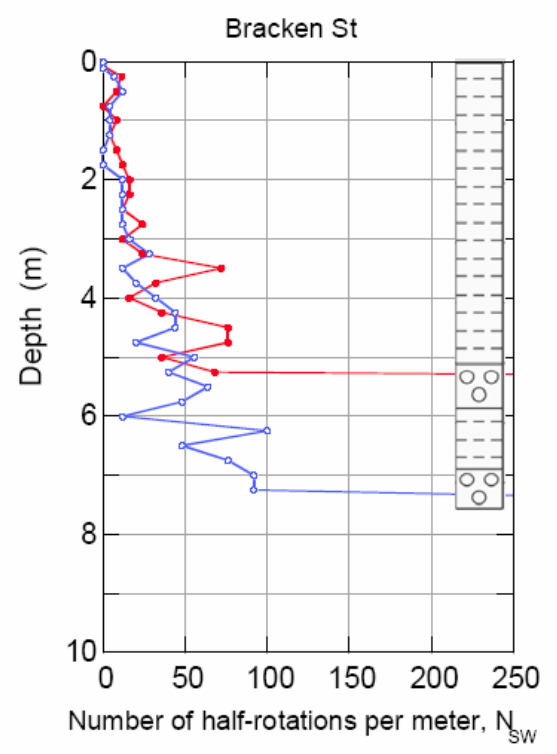

\section{Soil profile symbols: $[\because$ sandy $E-2$ silty $\quad$ O O with gravel}

Figure 4.6: $\quad$ Post-event penetration resistance in Dallington (St Paul's Church/School) and Avonside (Bracken St) measured in SWS tests. 

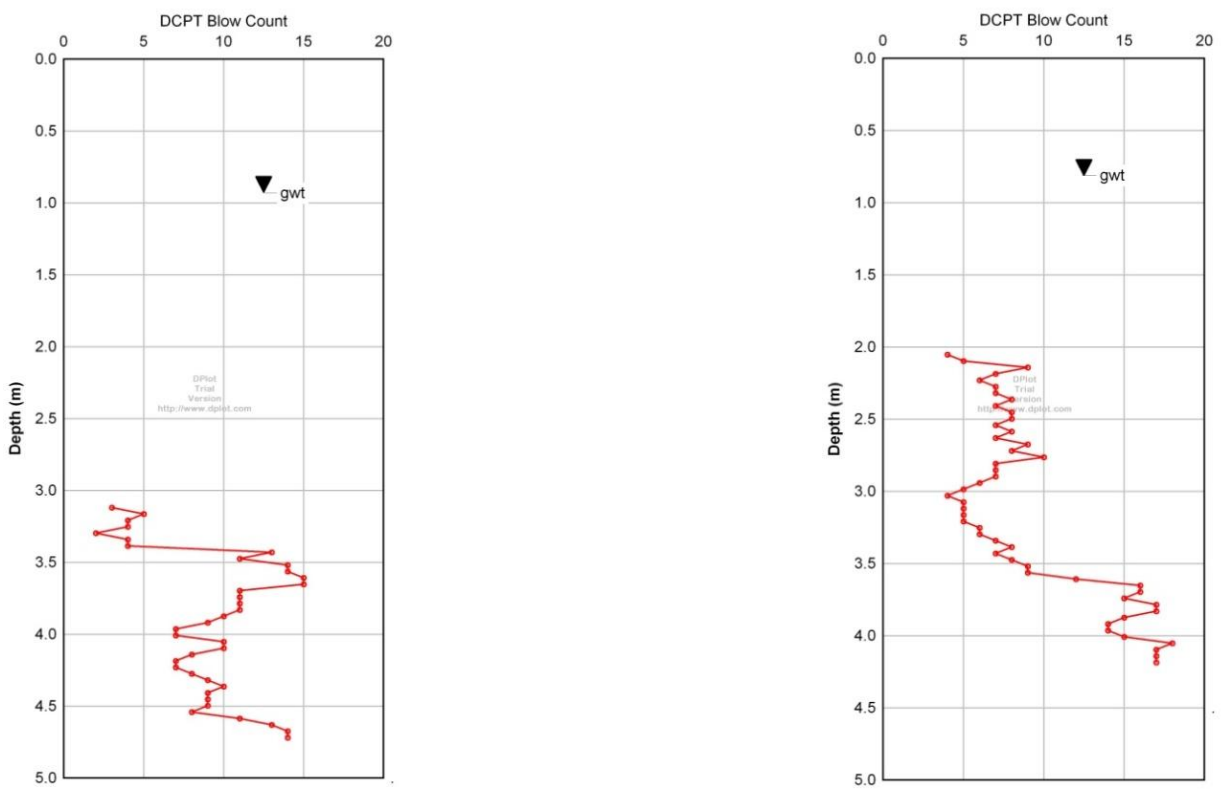

Figure 4.7: $\quad$ Results of DCPT performed at a residence on Bracken St, Avonside.

Shear Wave Velocity, $\mathrm{m} / \mathrm{s}$
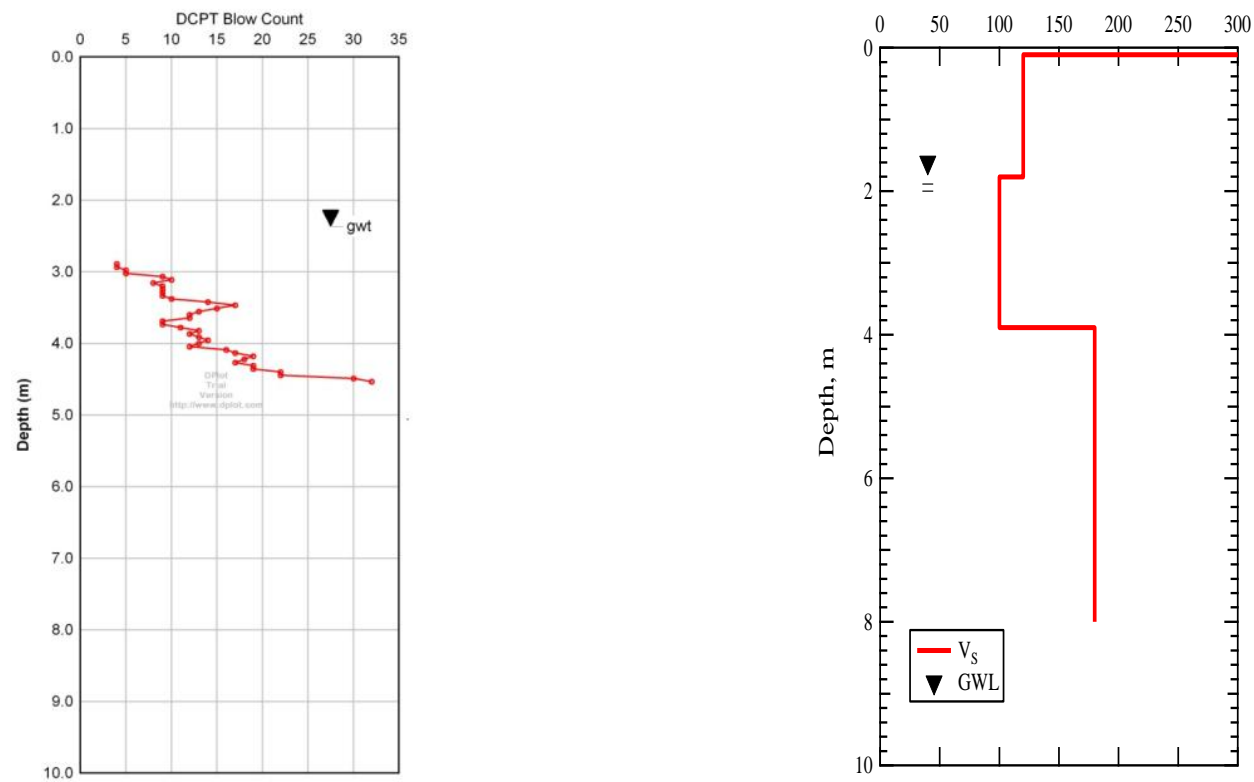

Figure 4.8: $\quad$ Results of DCPT and SASW tests performed at St Paul's Church in Dallington.

The nonintrusive SASW (Spectral Analysis of Surface Waves) method is a common procedure used for obtaining shear wave velocity (Vs) profiles for liquefaction analyses (Stokoe et al. 1994, Andrus and Stokoe 2000, Youd et al. 2001). The SASW method is particularly well-suited for relatively shallow surveys conducted in areas with limited space where conventional multi-channel (MASW) arrays may not fit. Furthermore, the equipment used for the tests discussed herein is extremely light-weight and portable, and can be transported in a small backpack, which makes it ideal for earthquake reconnaissance work. Specifically, these SASW tests were conducted using three $4.5 \mathrm{~Hz}$ geophones and a 'pocket portable' dynamic signal analyzer (Quattro system) manufactured by Data Physics Corporation. The Quattro is USB-powered off a laptop and, despite its small size, has four input channels, two output channels, $205 \mathrm{kHz}$ simultaneous sampling rate, 24 bit ADC's, $110 \mathrm{~dB}$ dynamic range, and 100 $\mathrm{dB}$ anti-alias filters. A common 4 to $6 \mathrm{~kg}$ sledge hammer can typically be used as a dynamic source to profile approximately 6 to $10 \mathrm{~m}$ deep with this equipment in less than 15 minutes.
The Vs profiles must be corrected for overburden pressure (Vs1) prior to evaluating soil liquefaction triggering. Generally speaking, even without this correction any soil layers with Vs less than $150 \mathrm{~m} / \mathrm{s}$ are quite soft and may be potentially liquefiable. However, it will be noted that Vs measurements alone cannot definitively determine liquefaction susceptibility, as the type of soil (i.e. clay or sand), not just its stiffness/velocity, is a key factor. The Vs profile shown in Figure 4.8 indicates soft soils down to $8 \mathrm{~m}$ depth, with the softest soils between approximately 2-4 $\mathrm{m}$.

Further to the east of Dallington, extensive liquefaction, including substantial lateral spreading, was observed in Porritt Park (Wainoni), which is enclosed by the Avon River and a diverted stream around the park. Large sand boils covered substantial areas of the park (Figure 4.9). Parallel cracks spaced regularly along drainage lines were indicative of slumping and spreading towards the north and south branches of the stream. A couple of hockey fields located in the park were severely damaged by the liquefaction, resulting in a very uneven, bumpy surface of the fields. 


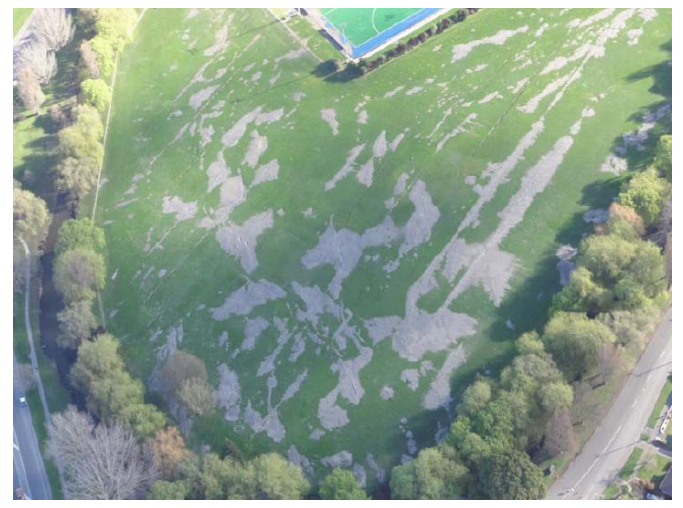

(a) Aerial view: massive sand boils with large number of parallel cracks along drainage lines (from a helicopter flyover on the afternoon of Friday September 10).

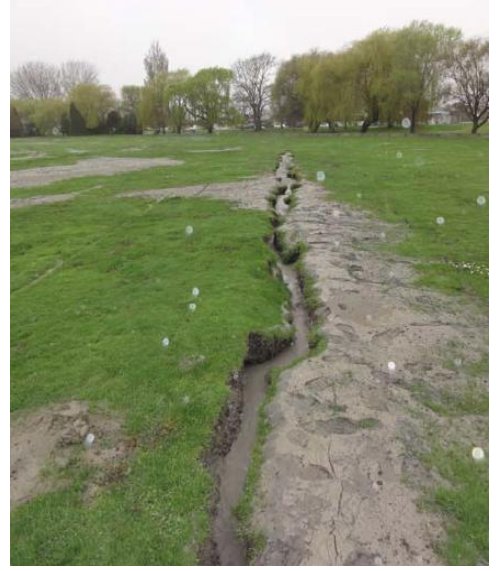

(b) $\sim 10 \mathrm{~cm}$ wide lateral spread crack.

Figure 4.9: $\quad$ Massive sand boils and lateral spreading cracks at Porritt Park $\left(43.516278^{\circ} S, 172.689917^{\circ} \mathrm{E}\right)$.
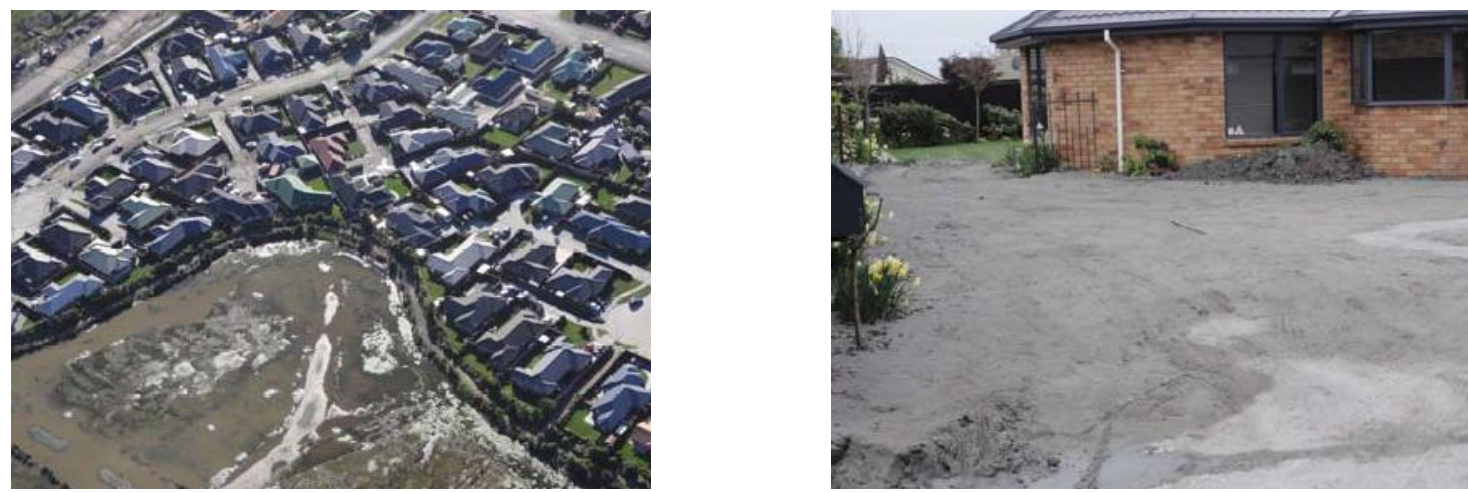

(a) Aerial view of the southern edge of Bexley which was severely affected by liquefaction and lateral spreading; (b) Evidence of liquefaction in residential area (Seabreeze Cl).
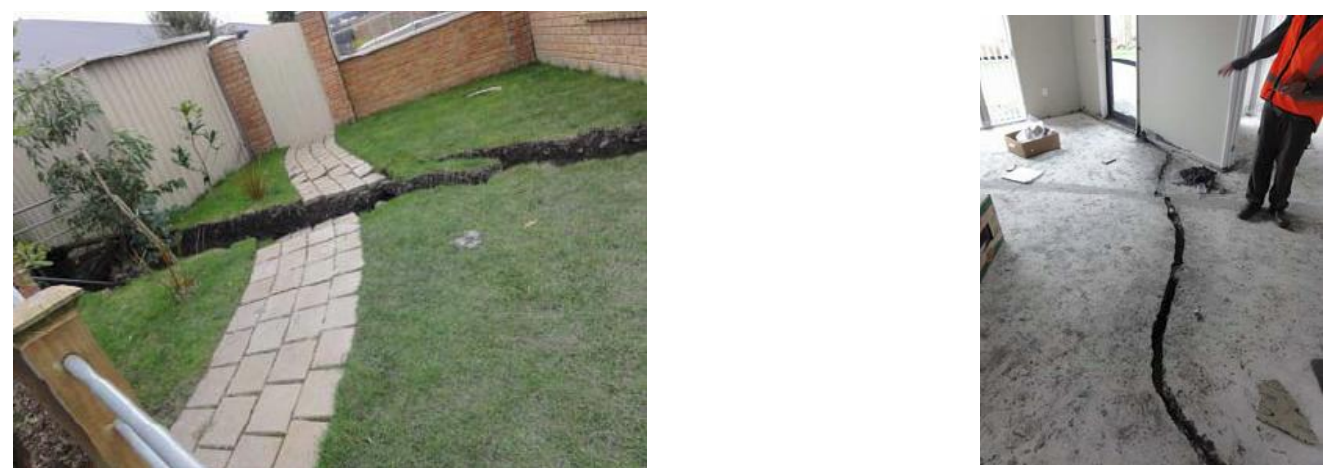

(a) Large ground cracks due to lateral spreading at Kokopu Pl; (d) Cracks in unreinforced slab induced by lateral spreading.

Figure 4.10: Evidence of extensive liquefaction severely affecting residential houses in Bexley. 


\subsection{Bexley}

Bexley is located further to the east along the Avon River, approximately one kilometre from the Avon-Heathcote Estuary. It is bounded by the Avon River on the east-side and by the Bexley Wetland on the south (Figure 4.10a). The residential area was developed in several stages, with the southern portion being reclaimed from the wetlands and developed in the late 1990s and later on.

Widespread liquefaction occurred in Bexley, affecting a large number of residential houses (Figure 4.10). Ground distortion (i.e., differential settlement, large ground cracks, deformation of paved surfaces and substantial sand boils) was observed at Seabreeze $\mathrm{Cl}$ and Kokopu Ln. Residential properties along the southern edge of Bexley (along the wetland walkway) were severely affected by lateral spreading. Large movement of the walkway towards the water, slumping of the terrace fill and large ground cracks on residential properties were observed in this area. Similarly, severe manifestation of lateral spreading was observed at the east end of Bexley (Parenga Pl).
An SWS test, DCPT, and SASW test were performed in the backyard of a house in Bexley; the results are shown in Figure 4.11. Based on the bore hole augered for the DCPT test, the ground water table was at a depth of $\sim 1.5 \mathrm{~m}$ and the top of the liquefied layer was at a depth of $\sim 1.6 \mathrm{~m}$. The SASW test was performed $\sim 10 \mathrm{~m}$ away from the DCPT sounding.

\subsection{Liquefaction manifestation in other areas of Christchurch}

Widespread liquefaction also occurred in the suburbs of Halswell (southwest of Christchurch) and Brooklands (northeast of Christchurch). In Spencerville (also north-east of Christchurch), liquefaction occurred and lateral spreading affected a limited area. In these suburbs, the manifestation of liquefaction and its effects on residential houses and lifeline systems were similar to those previously described. Again, the severity of liquefaction and associated building damage varied even within a given neighbourhood, depending on the soil profile, distance from the free face, slope grade, and/or structural and foundation details.
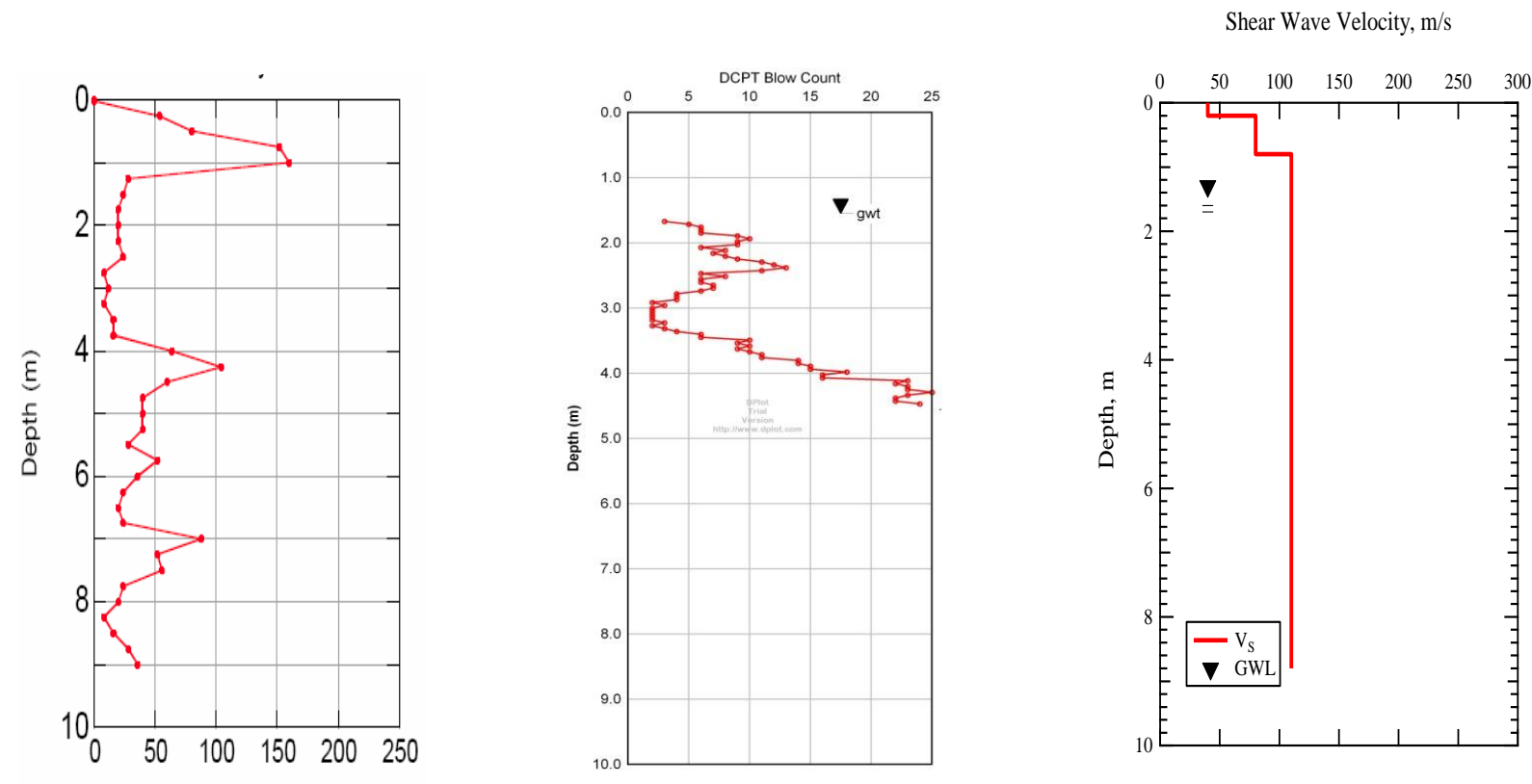

Number of half-rotations per meter, $\mathrm{N}_{\mathrm{SW}}$

Figure 4.11: Results of SWS test, DCPT, and SASW test performed in the backyard of a house in Bexley.
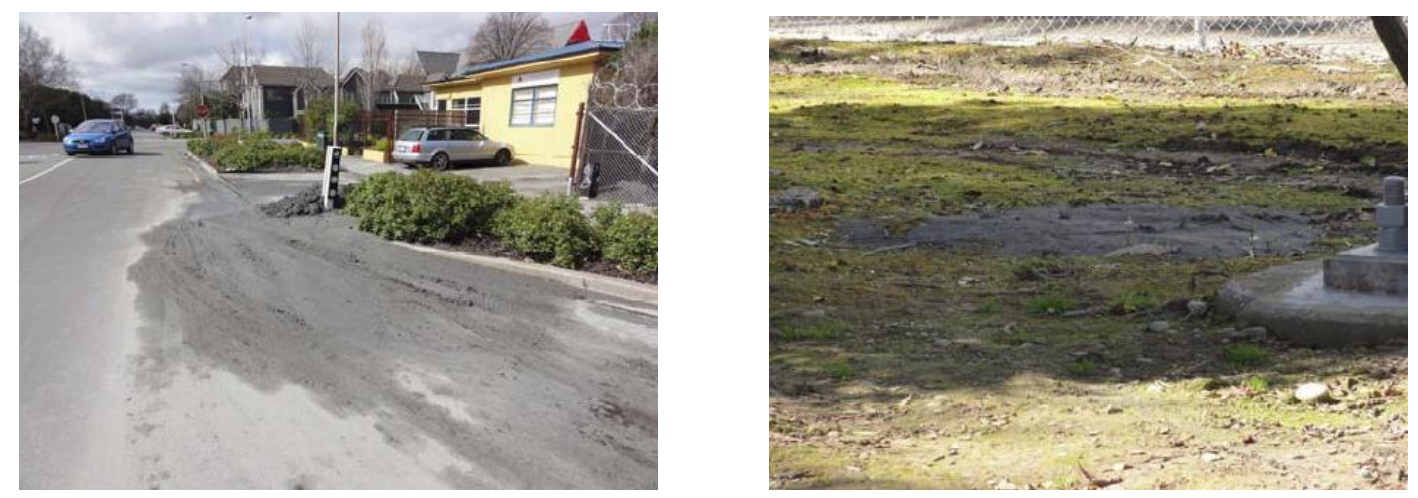

(a) Evidence of liquefaction at Peterborough St - Madras St (CBD); (b) Sand boil in the foundation soils of a transmission tower (sub-station northeast of Greers Rd-Ruddenklau Ln, Bishopdale) .

Figure 4.12: $\quad$ Evidence of limited/partial liquefaction in areas of Christchurch. 
Limited or partial liquefaction was observed at numerous locations across the city, which manifested as scattered and relatively small (or within limited area) sand boils. In these places there was damage to roads, footpaths, and driveways as well as some house damage, but the liquefaction effects were moderate or mild. Figure 4.12 shows typical manifestation of limited liquefaction in CBD (Peterborough St) and in the backyard of a power sub-station on Greers Rd in Bishopdale. Other areas where liquefaction of limited extent was observed include Belfast (Engelfield Rd, near Main North Rd), Redwood (Barnes Rd, near Main North Rd), Fendalton (Queens Av), vicinity of English Park in St Alban's (Cranford St, Westminster St, Courtenay St, Trafalgar St, Sheppard St) and Burwood (DeVille Pl and DeBlog Pl). These areas of partial/limited liquefaction are shown in the liquefaction map in Figure 4.3.

The geotechnical reconnaissance team also conducted a quick drive-through reconnaissance along the Heathcote River, specifically targeting areas that were denoted as having highpotential for liquefaction-induced damage on the ECan liquefaction hazard maps (http://ecan.govt.nz/publications/ General/solid-facts-christchurch-liquefaction.pdf). However, there was very little evidence of ground distortion and liquefaction in this area, with only a few sand boils found in a period of about two hours of drive-through and on foot surveys.

\subsection{Characteristics of liquefied soils}

The ejecta from sand boils in areas affected by liquefaction were generally very similar and had several distinctive features. They were non-plastic fine sands and silty sands with an easily recognizable grey/blue colour.

Grain-size distribution curves of ejecta samples taken from Dallington (Gayhurst Rd), Porritt Park and South Kaiapoi (Courtenay Dr) are shown in Figure 4.13a. Figure 4.13b shows grain size distribution of soil samples taken from the SWS screw point (representative of the deepest layer penetrated in a SWS test), which shows significantly higher fines content.

Figure 4.14 shows the large sandboil from which a bulk sample of the sand was recovered. Featherstone Reserve at Pines Beach was the location (approximate position $43^{\circ} 22^{\prime}$ 52" S $\left.172^{\circ} 42^{\prime} 13^{\prime \prime} \mathrm{E}\right)$.
Figures 4.15-4.18 give electron micrographs of various fractions of the sand in relation to sieve size. The micrographs are all at the same magnification, 100 times, and show that the particles tend to be angular to subrounded in shape. As the particle size decreases the angularity of the particles increases.

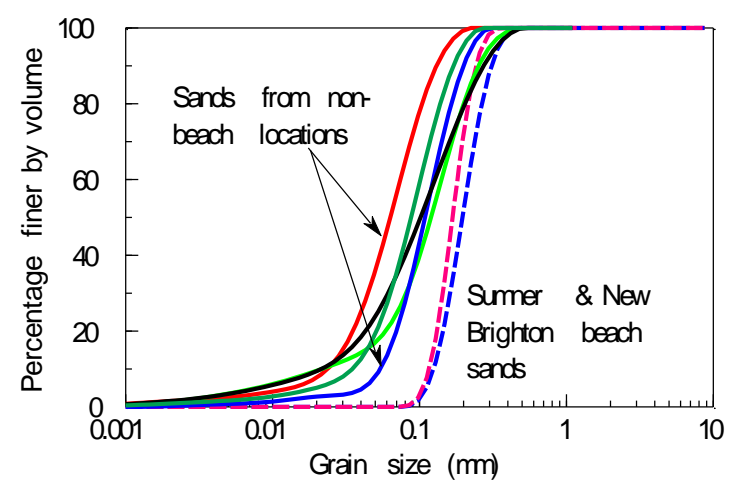

(a) Grain size distribution curves of sand boil samples obtained by laser diffraction analysis.

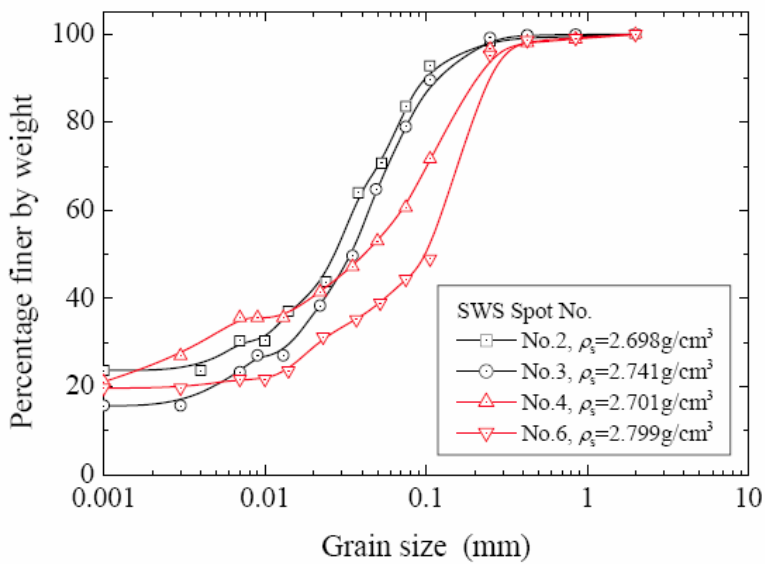

(b) Grain size distribution curves of soil samples taken from the SWS screw point (deepest tested layer) obtained by sieve and hydrometer analyses: Dallington (Nos. 2, 3), Bexley (Nos. 4,6).

Figure 4.13: Grain-size distribution curves of Christchurch and Kaiapoi soils.

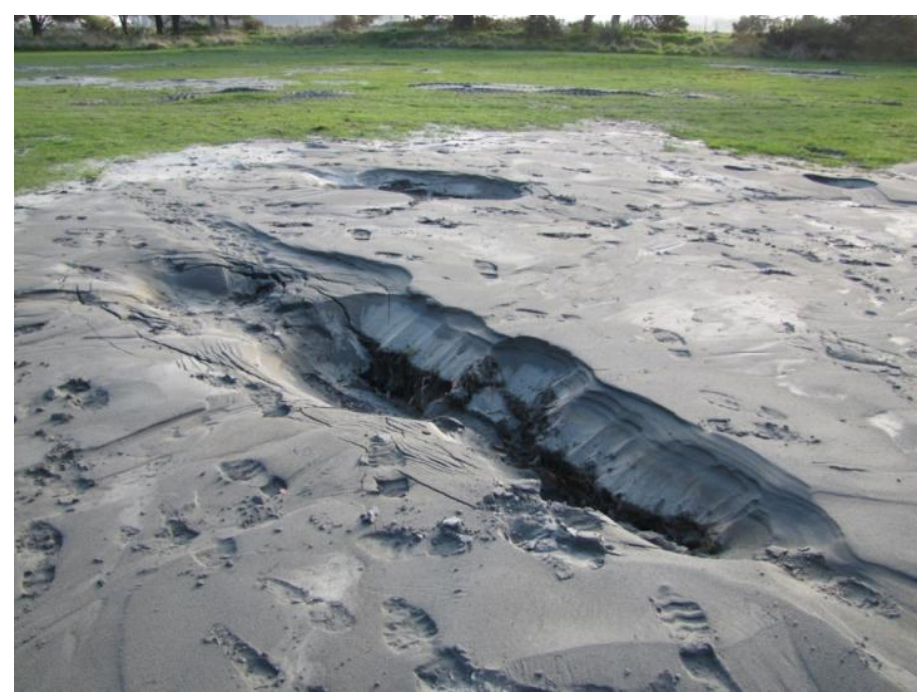

Figure 4.14: Sandboil in the Featherstone Reserve Pines Beach from which sand was taken for electron microscope pictures. 


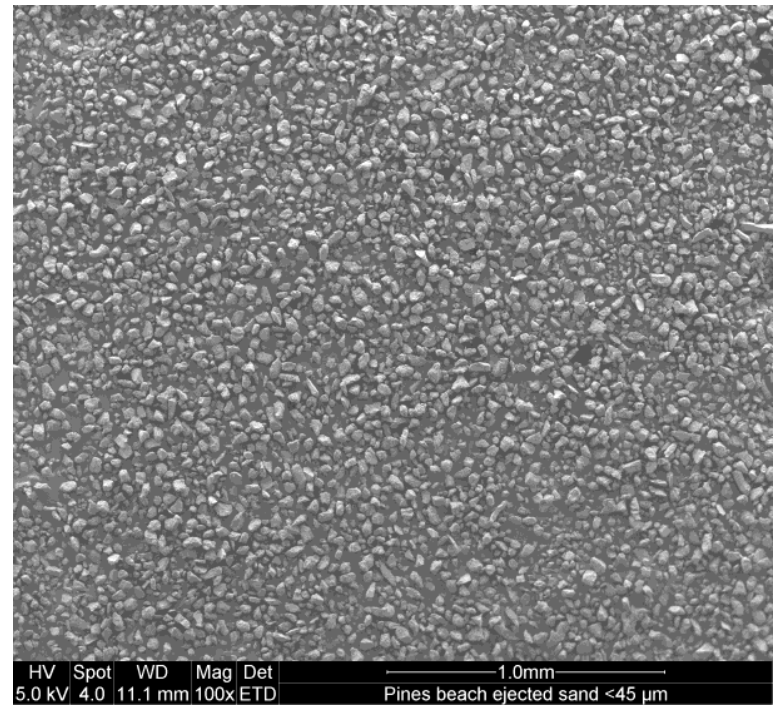

Figure 4.15: $\quad$ Sand particles retained on the 63 micron sieve.

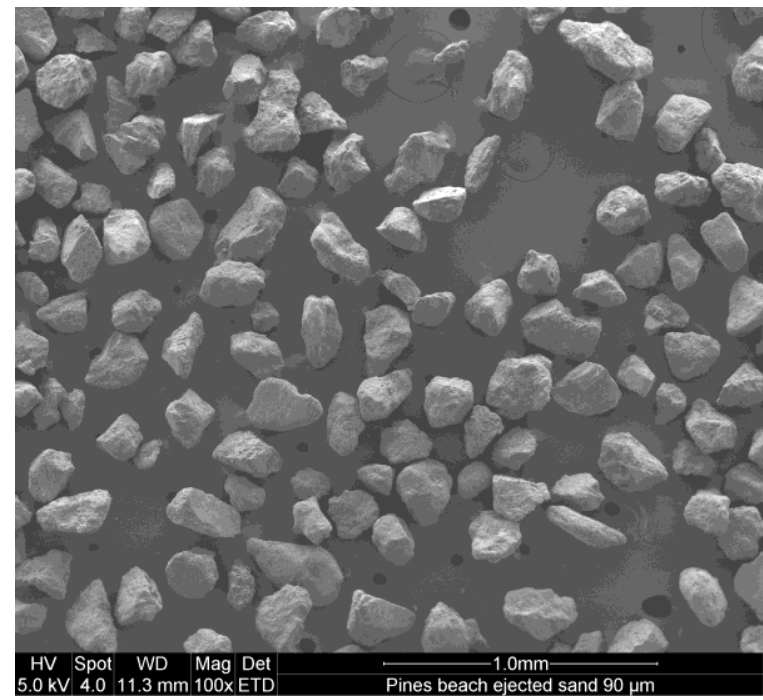

Figure 4.17: Sand particles retained on the 90 micron sieve.

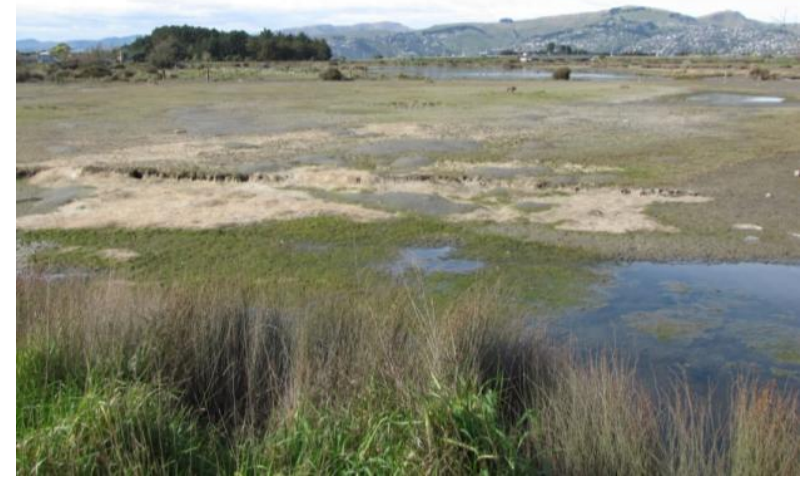

Figure 4.19: View of the Bexley Wetland at near high tide on Wednesday 29 September 2010. Prior to the earthquake this area was inundated at high tide.

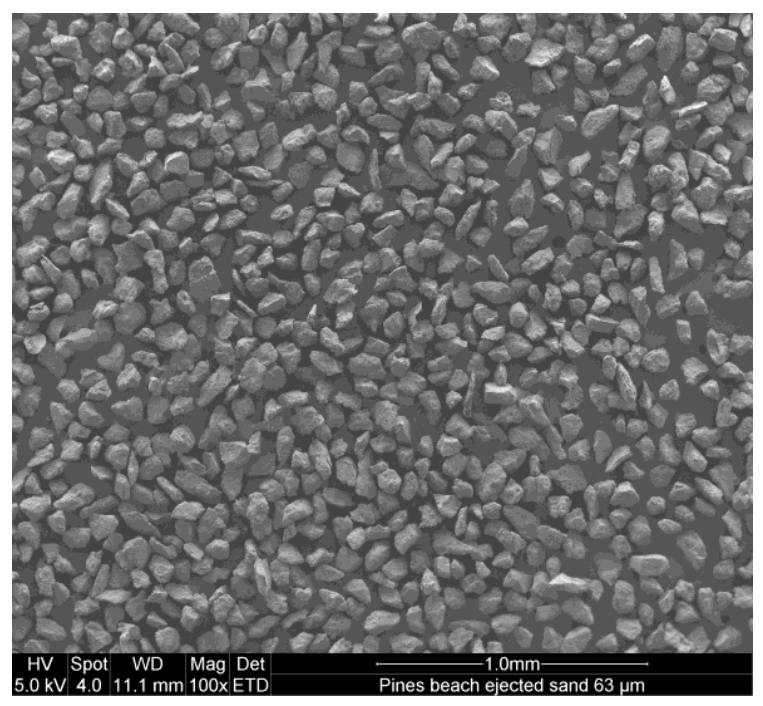

Figure 4.16: Sand particles passing the 45 micron sieve.

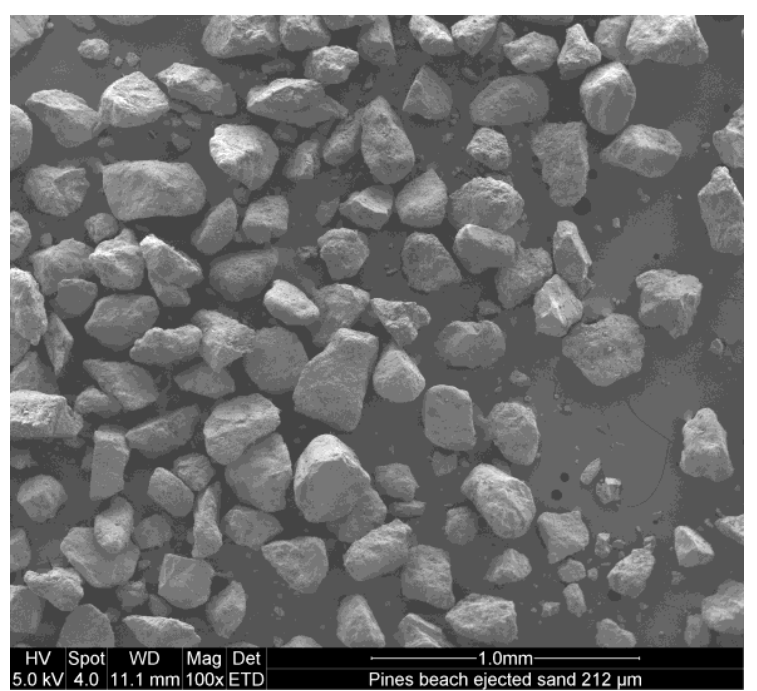

Figure 4.18: Sand particles retained on the 212 micron sieve.

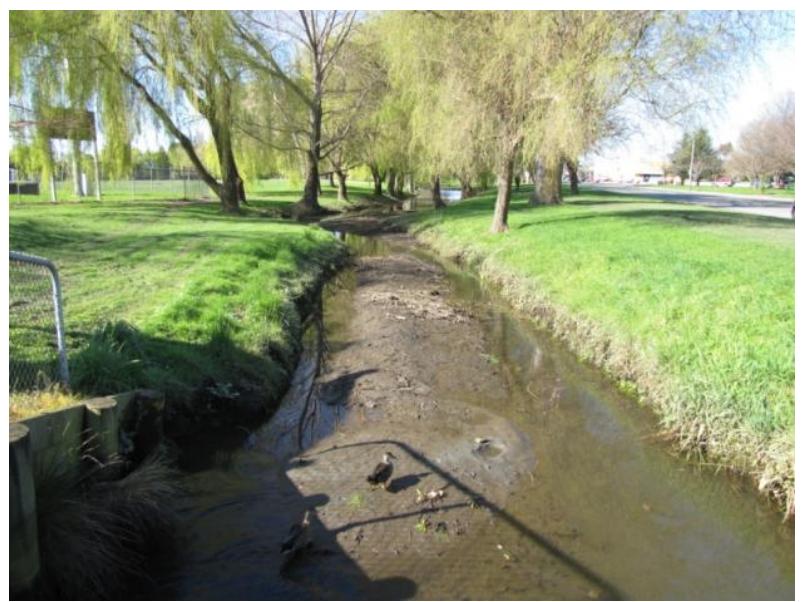

Figure 4.20: Photograph of the stream near Porritt Park on Wednesday, 15 September 2010. There is lateral spreading towards this stream from both sides. It is just possible to make out a sand boil in the midst of the stream bed debris to the right of the duck. Several other sand boils were visible along the stretch of heaved stream bed. 


\subsection{Effects of liquefaction and lateral spreading on} streambeds and wetlands

Residents of the Bexley area commented on the effect of the earthquake on the Bexley Wetlands. Figure 4.19 shows a view from walking path around the south of the subdivision.

Many sand boils are seen in the bed of the wetland area (at high tide on 29 September) which was inundated at high tide prior to the earthquake. Stream beds were also noticed to be heaved (Figure 4.20). A local resident confirmed that this was not how the stream bed appeared prior to the earthquake. In some places it was necessary to clear the stream bed soon after the earthquake.

\subsection{Google imaging as evidence of liquefaction}

A few hours after the earthquake, a GeoEye image of part of the area affected by the earthquake was captured. Since Saturday September 04 was a clear day, this image provided good evidence of liquefaction in some parts of the city. Figure 4.21 shows part of the GeoEye image covering Porritt Park (location about $43.515555^{\circ} \mathrm{S}, 172.685277^{\circ} \mathrm{E}$; the image date is 3 September 2010 because GMT, rather than the local time and date in Christchurch, is used by Google). Figure 4.9a shows a picture of Porritt Park taken from a helicopter on the afternoon of Friday, 10 September 2010.

Comparison of these two images (Figs. 4.9a and 4.21), and also observations from on-ground reconnaissance, demonstrates that GeoEye is able to give good indication of liquefaction. Not surprisingly, it turns out that the key to this identification is contrast. The light colour of the ejected sand contrasts very well with the underlying green turf. In areas where the ejected sand covered the pavement, such as Bexley, the GeoEye image did not give such a clear indication of liquefaction.

Local residents commented that on the morning after the earthquake the Avon and Heathcote rivers had a milky

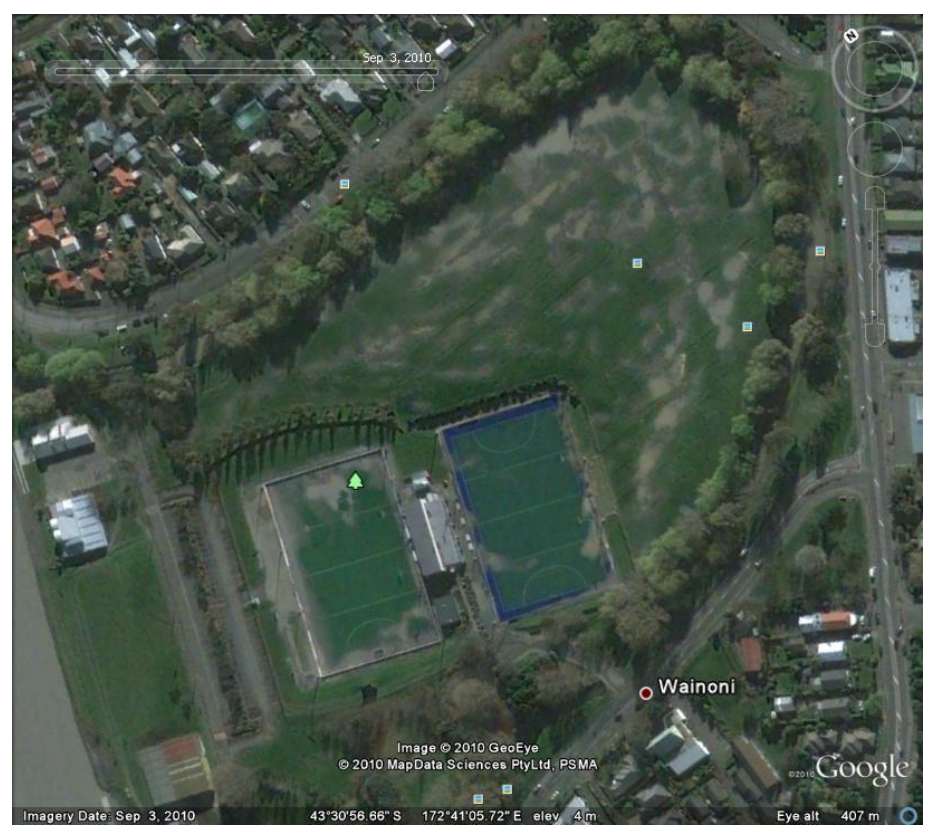

Figure 4.21: Sandboil in the Featherstone Reserve Pines Beach from which sand was taken for electron microscope pictures.

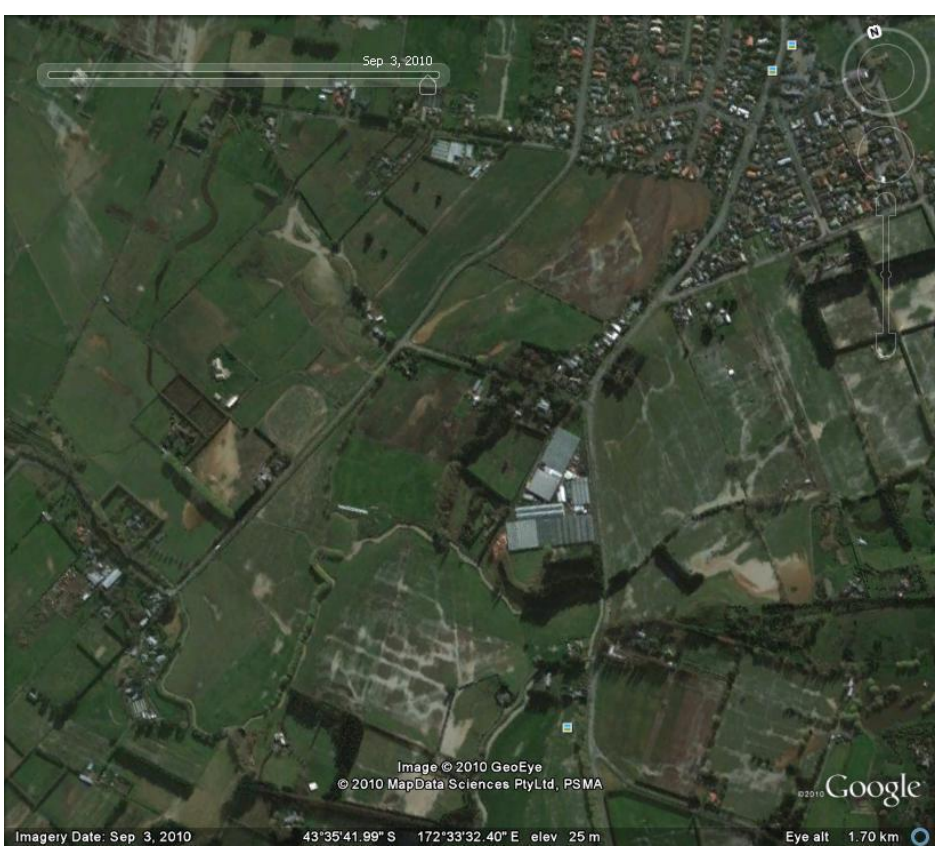

Figure 4.22: $\quad$ Part of Halswell as imaged by GeoEye after the earthquake. The ejected sand is accompanied by considerable volumes of water forming mini-lakes having a similar colour to the ejected sand (Google Inc., 2010). 
appearance. This is because the ejected sand contained enough fine material (typically $10 \%$ finer than about 50 microns) to stay in suspension for some time when mixed with water. A GeoEye image of part of the Halswell area is shown in Figure 4.22. Extrapolating from Figure 4.21, this figure suggests that there are some areas of Halswell where extensive liquefaction occurred. However, discussions with local residents revealed that a considerable volume of water came to the ground surface along with ejected sand, and this water took on a milky colour. So, the ejected sand could not be distinguished from the water in the satellite image. Some days after the earthquake this water had subsided.

In conclusion, comparison of the GeoEye image with onground reconnaissance confirms that, provided there is enough colour contrast between the ejecta and the surrounding ground, the satellite image gives a useful indication of liquefaction. However, when large volumes of water are ejected with the sand there may be a false indication of the amount of ejecta present.

\subsection{Town of Kaiapoi}

The town of Kaiapoi (population $\sim 10,000$; area $\sim 5 \mathrm{~km}^{2}$ ) is situated about $17 \mathrm{~km}$ north of Christchurch, near the northeastern end of the Canterbury Plains. At Kaiapoi, recent Holocene sediments, approximately $100 \mathrm{~m}$ thick, overlie 300$400 \mathrm{~m}$ of late Pleistocene sands and gravels, which in turn rest on rock and a greywacke basement rock (Brown and Webber, 1992; Berrill et al., 1994).

Present day Kaiapoi is divided into North Kaiapoi and South Kaiapoi by the Kaiapoi River (Figure 4.23). At the southeast end of Kaiapoi, the Waimakariri River meets the Kaiapoi River. The Waimakariri River and its abandoned channels significantly influenced liquefaction susceptibility of Kaiapoi. As discussed in the Geology chapter of this report and in Berrill et al. (1994), before 1868, the Waimakariri River had two branches. The north branch flowed in the channel of the present Kaiapoi River, and the south branch flowed in the now abandoned channel that was located between the present Kaiapoi River and Waimakariri River channels (Figure 2.9). Several old meander loops of pre-1868 Waimakariri River have deposited loose silty sands both north and south of the present Kaiapoi River. Also, the ground water table is generally shallow within 1-2 m of the ground surface.

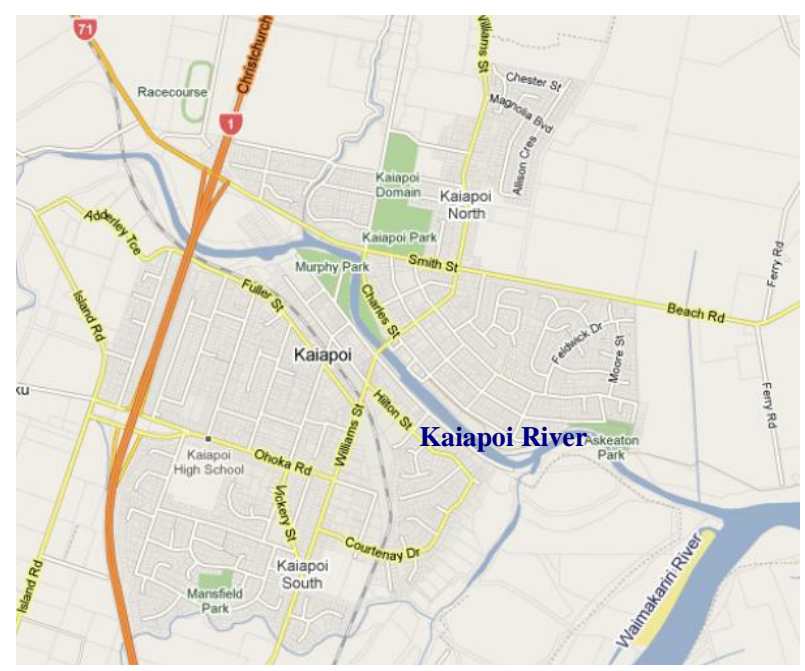

Figure 4.23: Map of present day Kaiapoi (Google Inc., 2010).
Parts of North Kaiapoi liquefied during the 1901 Cheviot Earthquake. Berrill et al. (1994) provide an excellent summary of the liquefaction that occurred in Kaiapoi during the 1901 event. Particularly, they presented historical evidence of the occurrence of liquefaction in the northeast section of Kaiapoi, at the east end of Charles and Sewell streets.

\subsubsection{North Kaiapoi}

In the 2010 Darfield Earthquake, widespread liquefaction occurred north of the Kaiapoi River (Charles St, Sewell St, Cassia St) affecting a large number of residential houses. The houses in this area are typically single- or two-storey brick/stone block masonry or timber structures on spread footings. Figure 4.24 shows areas of severe and moderate-tolow liquefaction in the town of Kaiapoi. A strong motion station located in north Kaiapoi recorded a PGA of approximately $0.32 \mathrm{~g}$ (geometric mean of the horizontal components) during the earthquake.

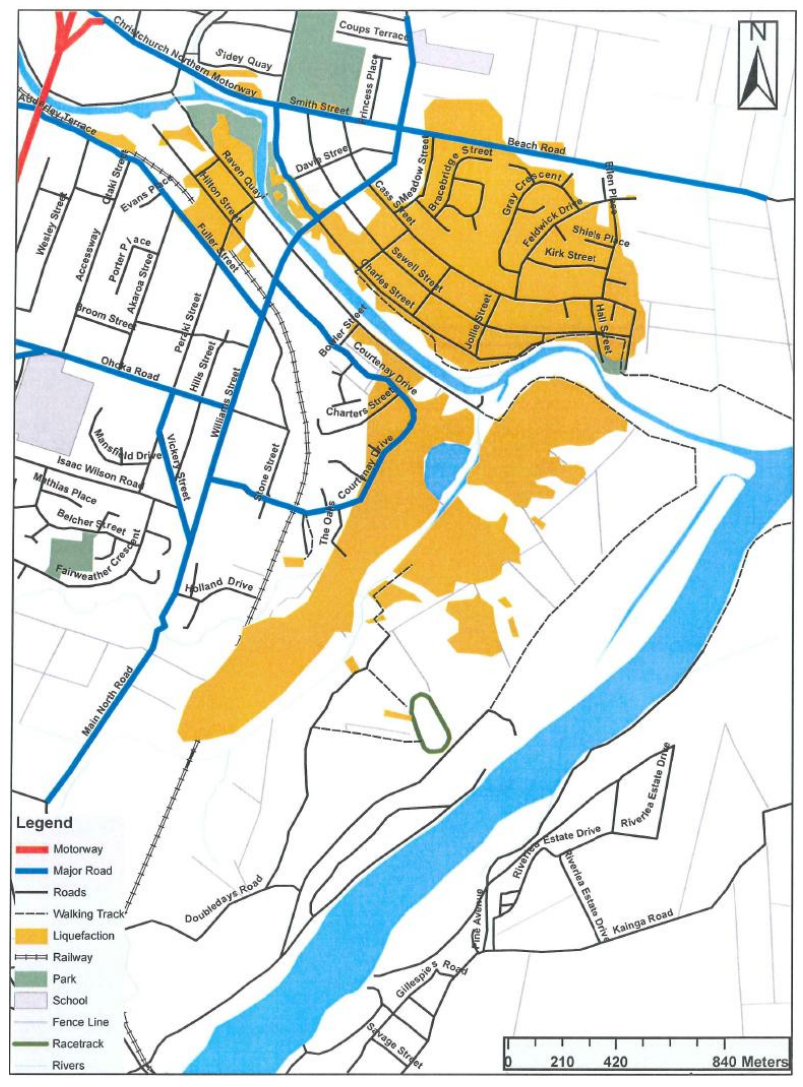

Figure 4.24: Areas of observed liquefaction in the town of Kaiapoi due to the 2010 Darfield earthquake (the liquefaction map is based on surface manifestation of liquefaction visible on aerial photographs and compiled evidence from ground surveying).

The liquefaction was particularly intense, producing massive sand boils of grey, silty sand, at Cassia Place and at the east end of Charles and Sewell streets. In the worst hit area, the silty sand ejecta was about $400 \mathrm{~mm}$ thick, as shown in Figure 4.25. Some residents reported geysers appearing in the backyard following the earthquake, often forming a small pond near the house that remained for several days after the event. An SWS test and DCPTs were performed by the team in this area, with the SWS test indicating loose/soft soils up to depths of 8-9 m (Figure 4.26). 

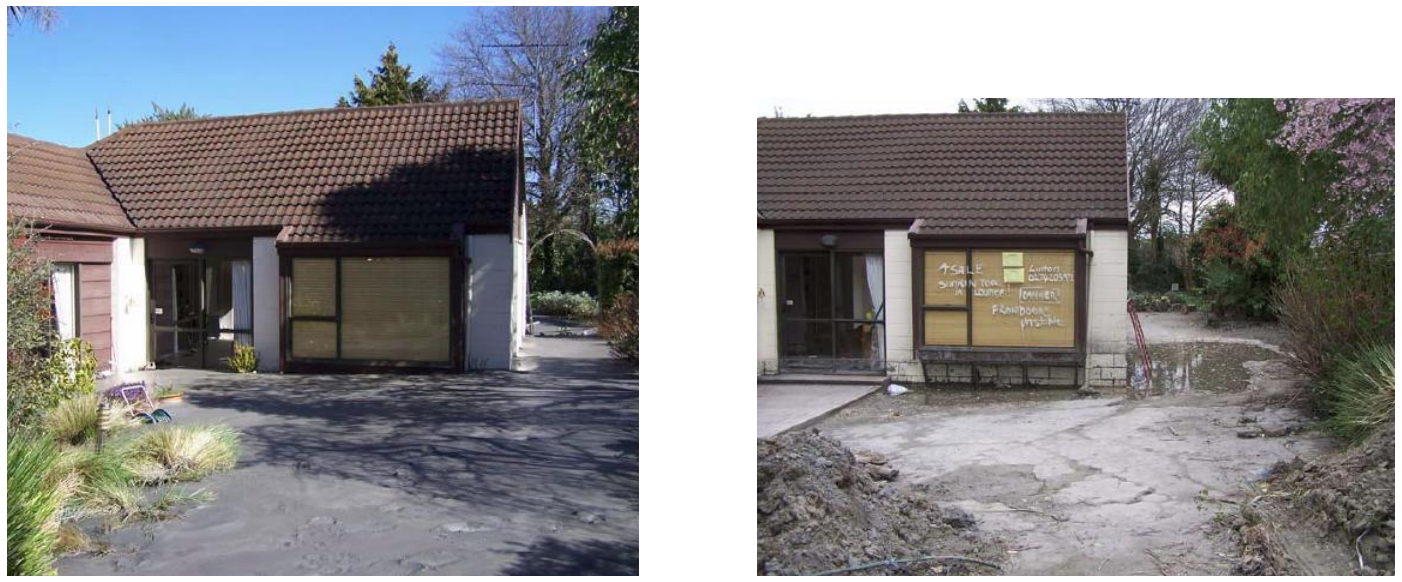

(a) 400 mmm thick layer of silt-sand-water mixture covering a residential property affected by very severe liquefaction; (b) same-angle view, but after the clean up of sand boils.
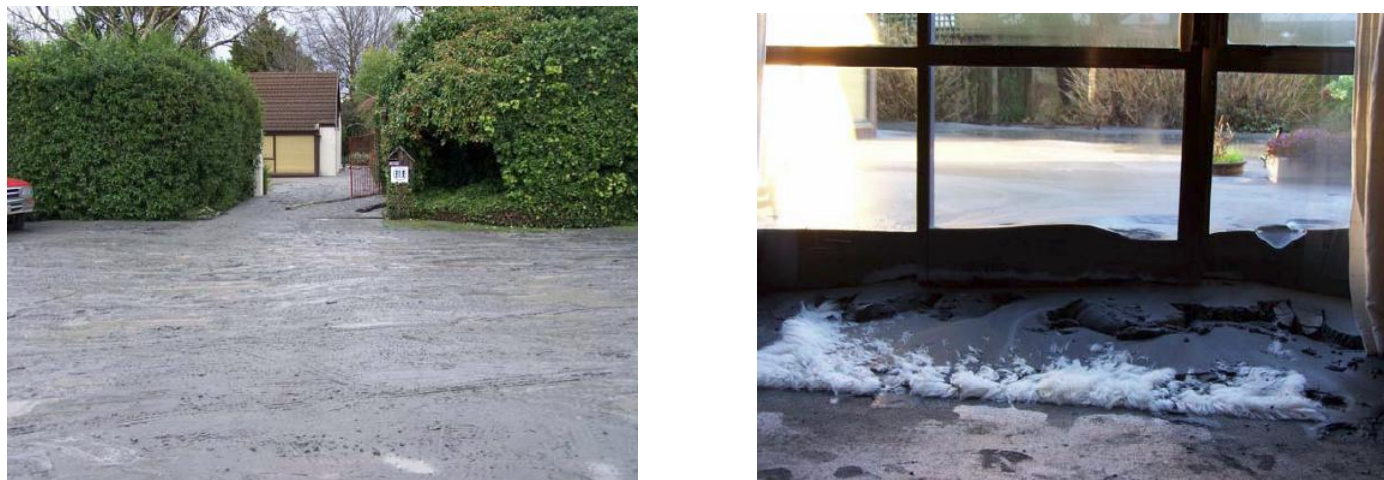

(c) View from the street (before clean up); (d) liquefied silt-sand-water mixture covering the ground outside the house and a rug inside the house (seen through a window from inside the house).

Figure 4.25: Manifestation of very severe liquefaction in residential area at Cass Pl, North Kaiapoi.
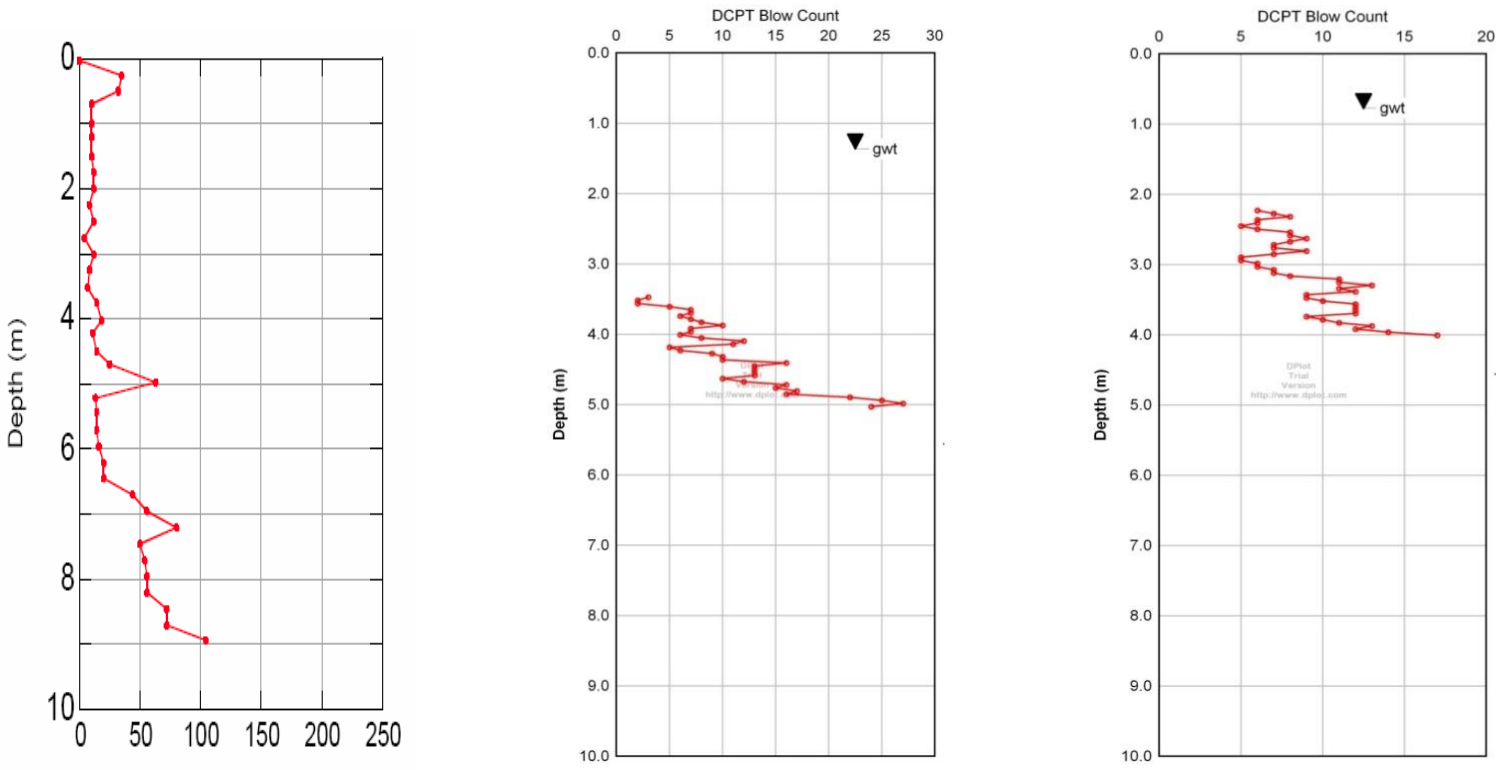

Number of half-rotations per meter, $\mathrm{N}_{S W}$

Figure 4.26: Results of SWS test and DCPTs performed in the backyard of a house at Cassia Pl.

As determined from the bore holes augered for the DCPTs the depth to the ground water table and to the top of the liquefied layer differed between the two test locations at Cassia $\mathrm{Pl}$ although the test locations were only $\sim 25 \mathrm{~m}$ apart. However, the surface elevation of the two test locations differed by about $0.5 \mathrm{~m}$. As a result, the elevations of the ground water table are similar for the two test locations, with the depth to the top of the liquefied layer differing slightly. As with the site on Bracken St (Figure 4.4), a 100 to $150 \mathrm{~mm}$ thick, very wet, very soft clay/plastic silt layer overlies the liquefied layer. 


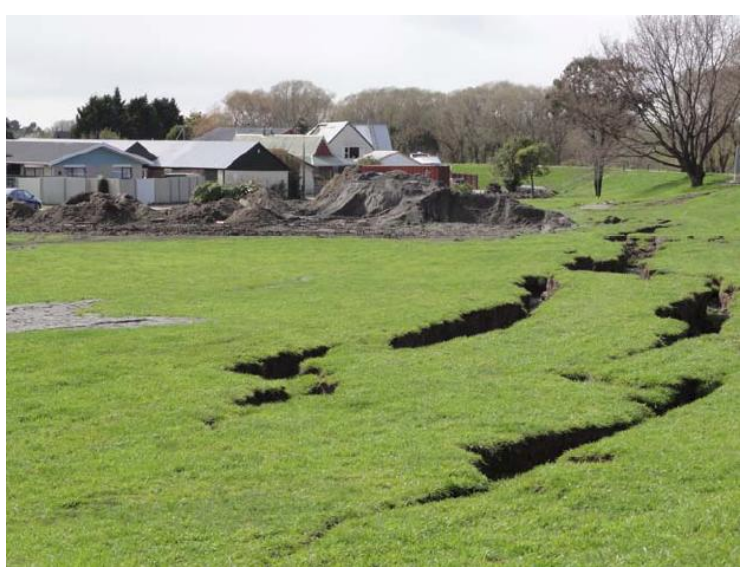

(a) Lateral spread and slumping of the north stopbank of the Kaiapoi River near the east end of Charles St; note the huge piles of cleaned up sand obstructing the view of the houses.

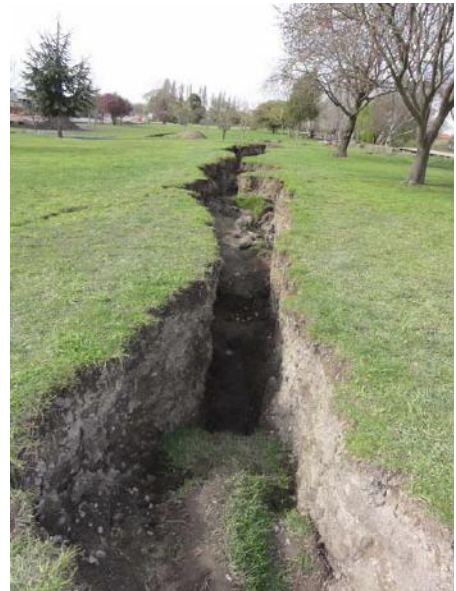

(b) Lateral spreading of the north stopbank of Kaiapoi River (Charles St-Jones St).

Figure 4.27: Evidence of liquefaction and lateral spreading along Charles St and the north stopbank of the Kaiapoi River.
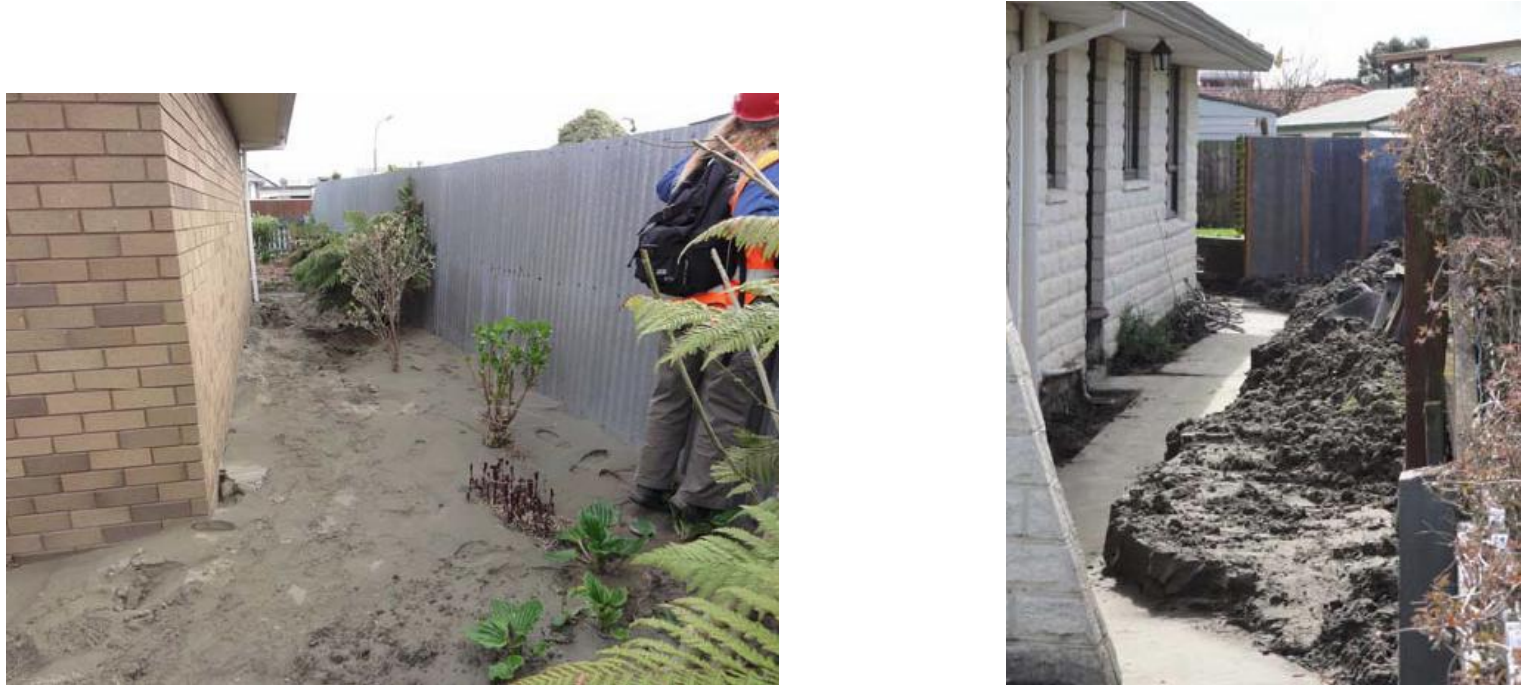

(a) Evidence of extensive liquefaction at the east end of Charles St.
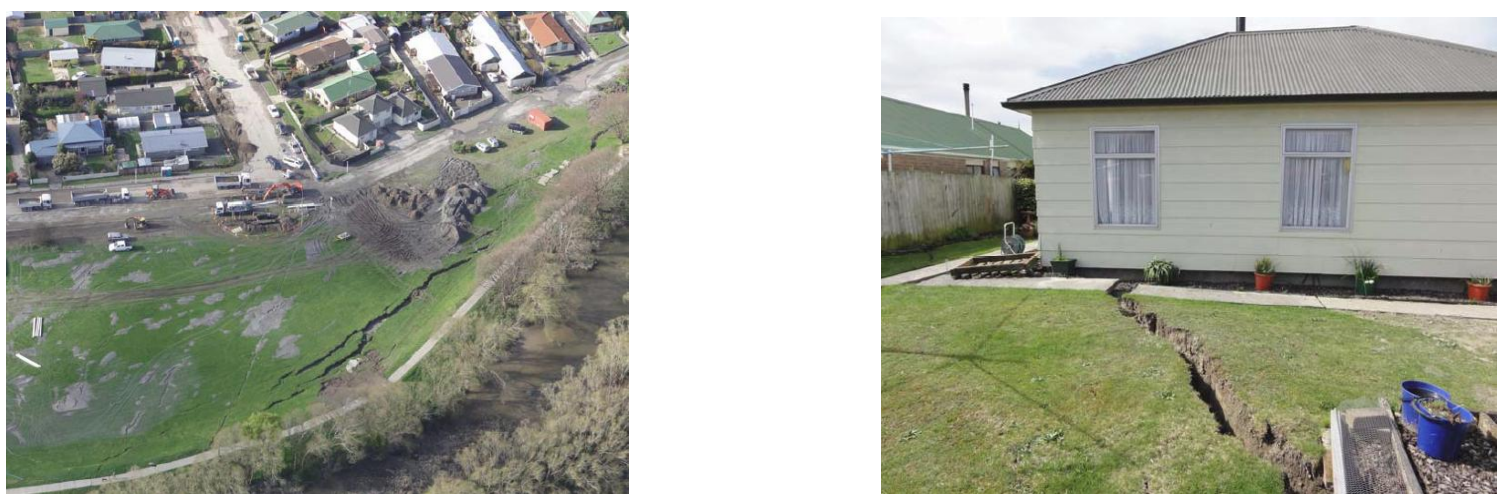

(b) Lateral spreading resulting in a large ground distortion in foundation soils (Charles St).

Figure 4.28: Liquefaction and lateral spreading in North Kaiapoi.

In this general area, including near the east end of Charles St and Sewell St, the liquefaction led to large settlement of many houses, including differential settlement that resulted in structural damage. The large ground distortion, cracks and fissures in the ground caused significant damage to buried lifelines in this area. The intensity of liquefaction gradually decreased from severe to moderate-to-mild and no liquefaction when moving away to the north or west from the Beswick StCass St-Askeaton Dr block. 
The area along the Pegasus Bay Walkway (from the Kaiapoi Visitor Information Centre on the east to Askeaton Park on the west) was affected by significant lateral spreading with large cracks and fissures in the sloping ground towards Charles St (Figure 4.27). Residential houses in this area were affected both by liquefaction and lateral spreading (Figure 4.28). The reconnaissance team carried out detailed ground surveys of lateral spreading along several profiles at this location which will be presented in future more detailed publications. In addition two bore holes were made using a hand auger. However, the profile largely consisted of random fill (gravels/cobbles and wood), making it difficult to advance the auger. One of the bore holes went down to a depth of $\sim 5.5 \mathrm{~m}$, yet a thick liquefied layer could not be found. However, thin $(<100 \mathrm{~mm}$ ) alternating layers of loose saturated sand and very wet, very soft clay/plastic silt were encountered, particularly near a large lateral spread crack (Figure 4.27b). This lateral spread crack had no traces of ejecta in and/or immediately near it. This crack was closer to the river than ones that were filled with ejecta, which were an additional $30 \mathrm{~m}$ further from the river. It is possible, that the overlying soil layers slid on these alternating layers of loose sand and clay/plastic silt that likely liquefied/softened during the earthquake shaking.

\subsubsection{South Kaiapoi}

In South Kaiapoi, the most dominant ground failure feature was the liquefaction and massive lateral spreading that affected the eastern branch of Courtenay Drive. The area affected by lateral spreading, shown in Figure 4.29, was approximately $1 \mathrm{~km}$ long in the north-south direction and extended between $200 \mathrm{~m}$ and $300 \mathrm{~m}$ inland from the Courtenay Stream and Courtenay Lake. The lake was artificially created during the construction of the northern end of Courtenay Dr. Borrow material was removed from the area where the lake is presently located and used as hydraulic fill (about $1 \mathrm{~m}$ thick) for the northern branch of Courtenay Dr (WDC, 2010).

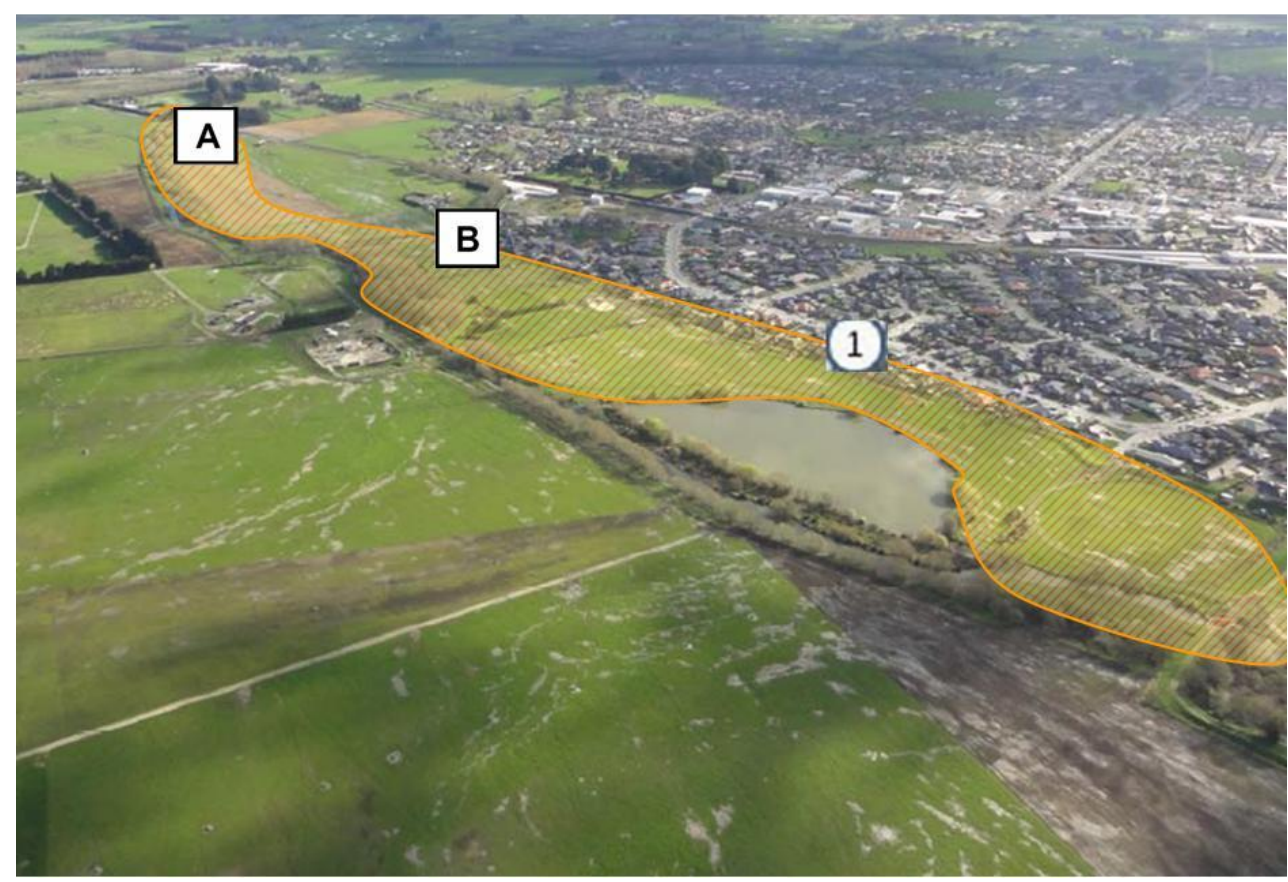

(a) Sand boils and area affected by lateral spreading around Courtenay Lake (from a helicopter flyover on Friday September 10).
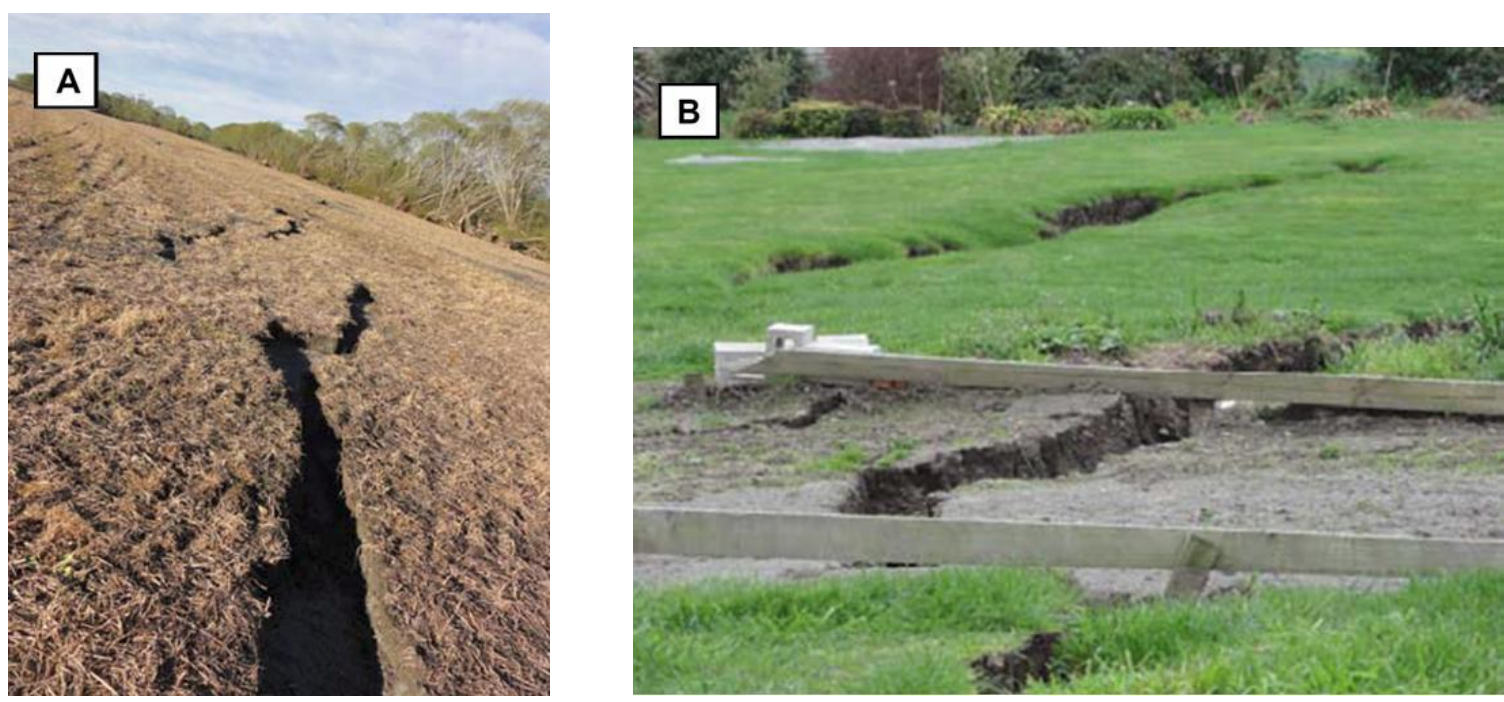

(b) Large lateral spread cracks in farm land (at B: $\left.43.3941389^{\circ} \mathrm{S}, 172.659750^{\circ} \mathrm{E}\right)$.

Figure 4.29: $\quad$ Massive lateral spreading at South Kaiapoi. 
The eastern edge of Kaiapoi is shown in aerial photographs taken after the Darfield earthquake (Figure 4.30). The outline of the 1865 Waimakariri river channel (Figure 2.9) is shown by the dashed red line. On the eastern side of Kaiapoi, the old channel passes underneath the present day Courtenay Dr area shown as position 1 , where severe damage to residential properties occurred due to lateral spreading (Figure 4.34). Further south at positions A and B (Figure 4.29), large cracks due to lateral spreading towards Courtenay Stream are evident. Along this stretch from position A to the north-east corner of Courtenay Dr (slightly north of position 1), detailed ground surveys were conducted along ten transects including measurement and mapping of width of cracks, vertical offsets, and geo-tagging of major cracks and other lateral spreading features. Figure 4.31 indicates geo-tagged major cracks and four transects of detailed measurements at position A.
Further south near the train tracks at position 2 (Figure 4.30), large sand boils formed (Figure 4.32). At position 3 (Figure 4.33), liquefaction resulted in damage to the train tracks. The photo in Figure 4.33 was taken from a position on Doubleday's $\mathrm{Rd}$ in a NNE direction along the tracks, indicating ground deformation and track movement. Moving north along the train tracks to positions 4 and A (Figure 4.30), Figure 4.31 provides a more detailed aerial view of liquefaction and lateral spreading crossing the tracks just south of Kaiapoi. Using the vehicles in the photo for scale gives a good indication of the significant size of these cracks and the volume of ejecta.

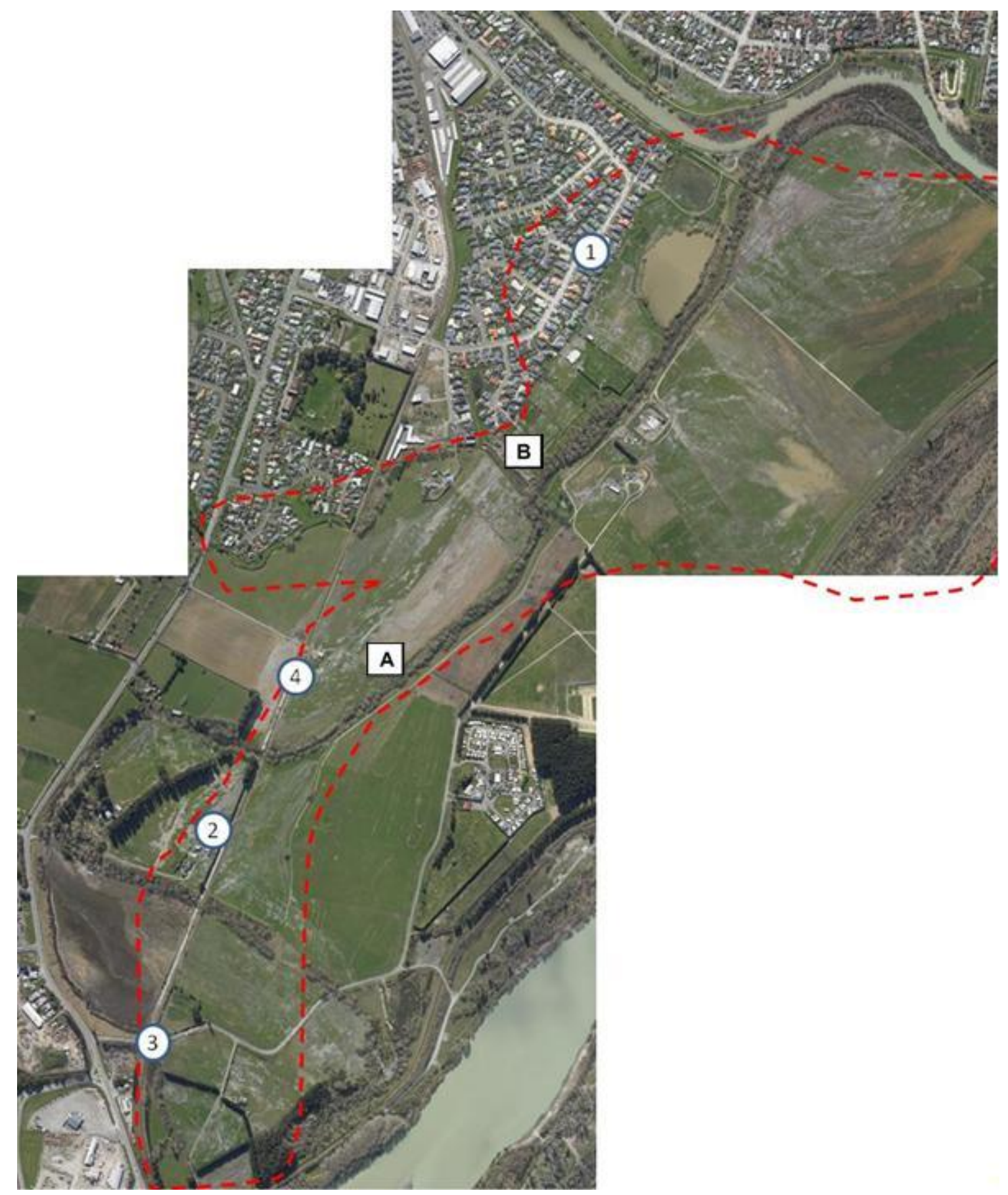

Figure 4.30: Aerial view of the lateral spreading area at South Kaiapoi. 


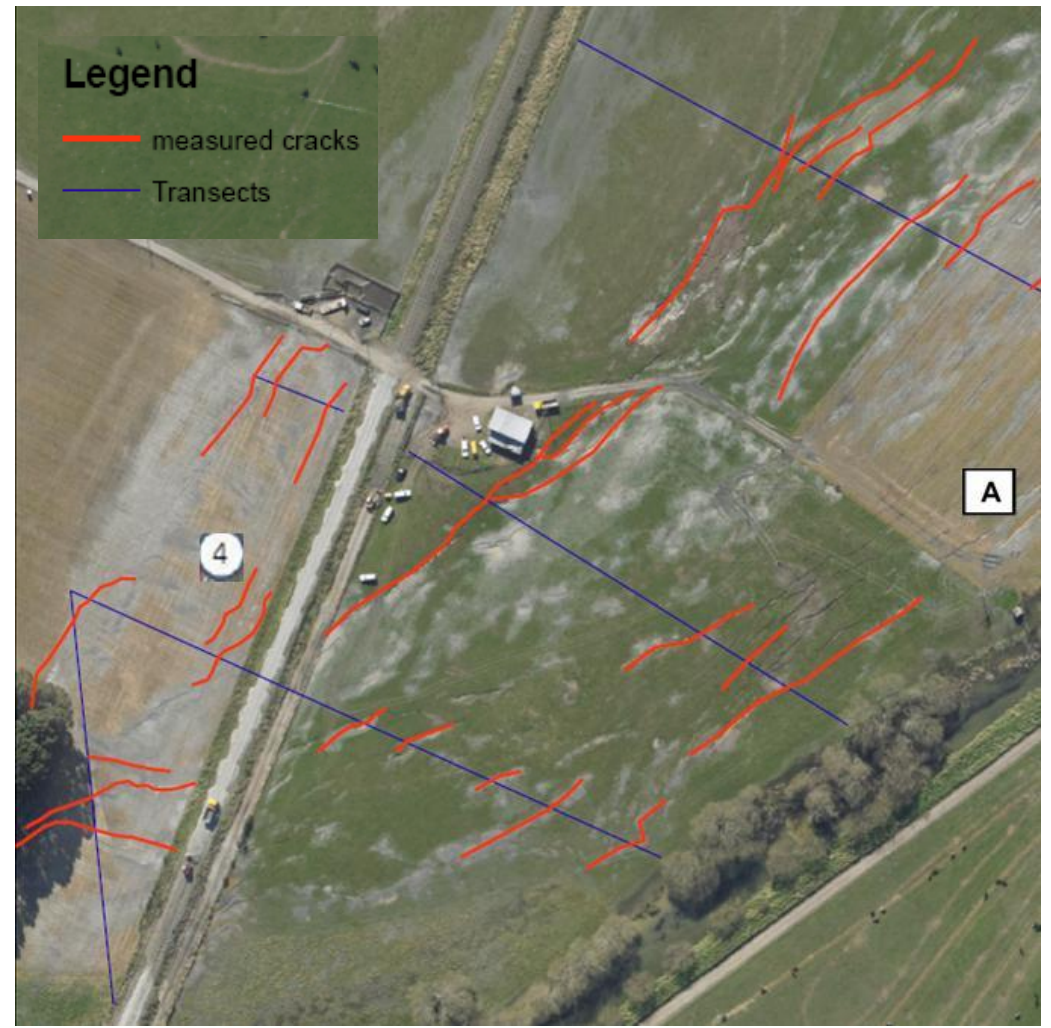

Figure 4.31: Aerial view of the lateral spreading area at position A at South Kaiapoi showing four transects of detailed ground surveys.

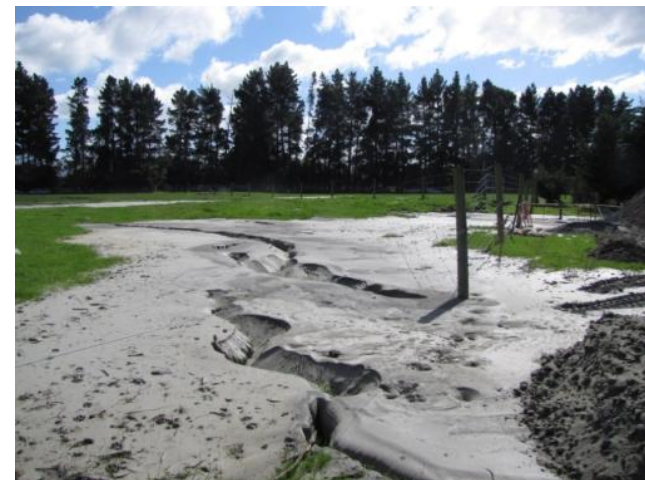

Figure 4.32: Sand boils in fields (position 2; $43.4026^{\circ} \mathrm{S}$, $172.6503^{\circ} \mathrm{E}$ ).

Lateral spreading resulted in large permanent lateral displacements on the order of 1.0-3.5 m with large ground cracks of about $0.5-1.5 \mathrm{~m}$ wide running through residential properties and houses along the east branch of Courtenay Dr. In this area, single storey and two storey houses suffered very severe damage due to large lateral ground movements including large tilt, loss of foundation support, tension cracks in foundations and slabs (Figure 4.34). It was significant that despite the extreme lateral movement of the immediate foundation soils and the foundations themselves, all houses showed large ductile deformation capacity and continued to carry gravity loads, despite literally being ripped in half in some cases. The reconnaissance team visited the area and conducted detailed inspections and measurements of the distorted houses on several occasions. There was clear evidence that the lateral movement, at least in some parts of the affected area, continued to develop/increase well after the main event. Two consecutive measurements of the width of a

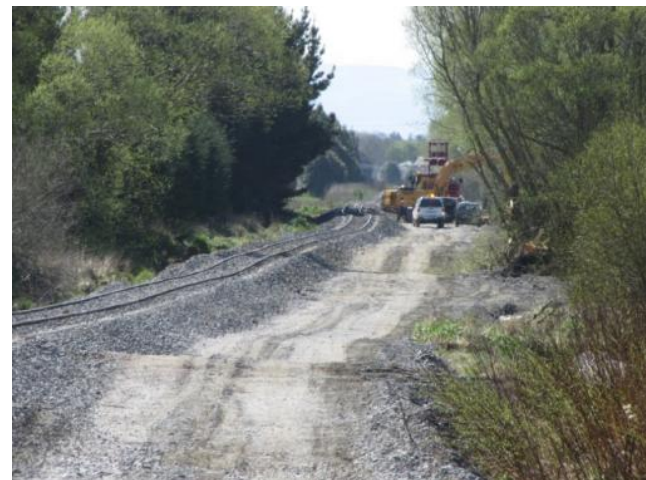

Figure 4.33: Damage to train tracks due to ground movement (position $3 ; 43.4068^{\circ} \mathrm{S}$, $\left.172.6489^{\circ} \mathrm{E}\right)$.

large ground crack carried out on 11 and 15 September showed an increase in width of $200 \mathrm{~mm}$ over this period (i.e. from $1.4 \mathrm{~m}$ to $1.6 \mathrm{~m}$ ). The residents of the neighbouring property reported new extensive cracks appearing in their house over the same time period. It is believed that this continued deformation was the result of a combination of creep due to static driving shear stresses, significantly softened soils and effects of aftershocks on a structure marginally stable under gravity loads.

An SASW test, DCPT and SWS test were performed at a home along Courtenay Dr. The results are presented in Figure 4.35 . 

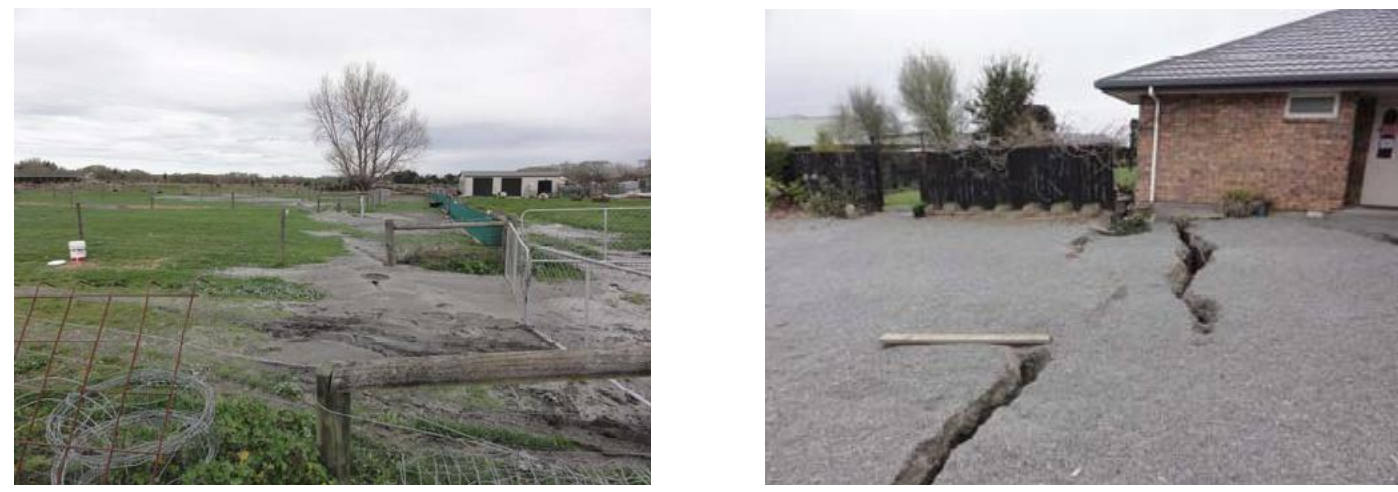

(a) Sand boils and lateral spread cracks.
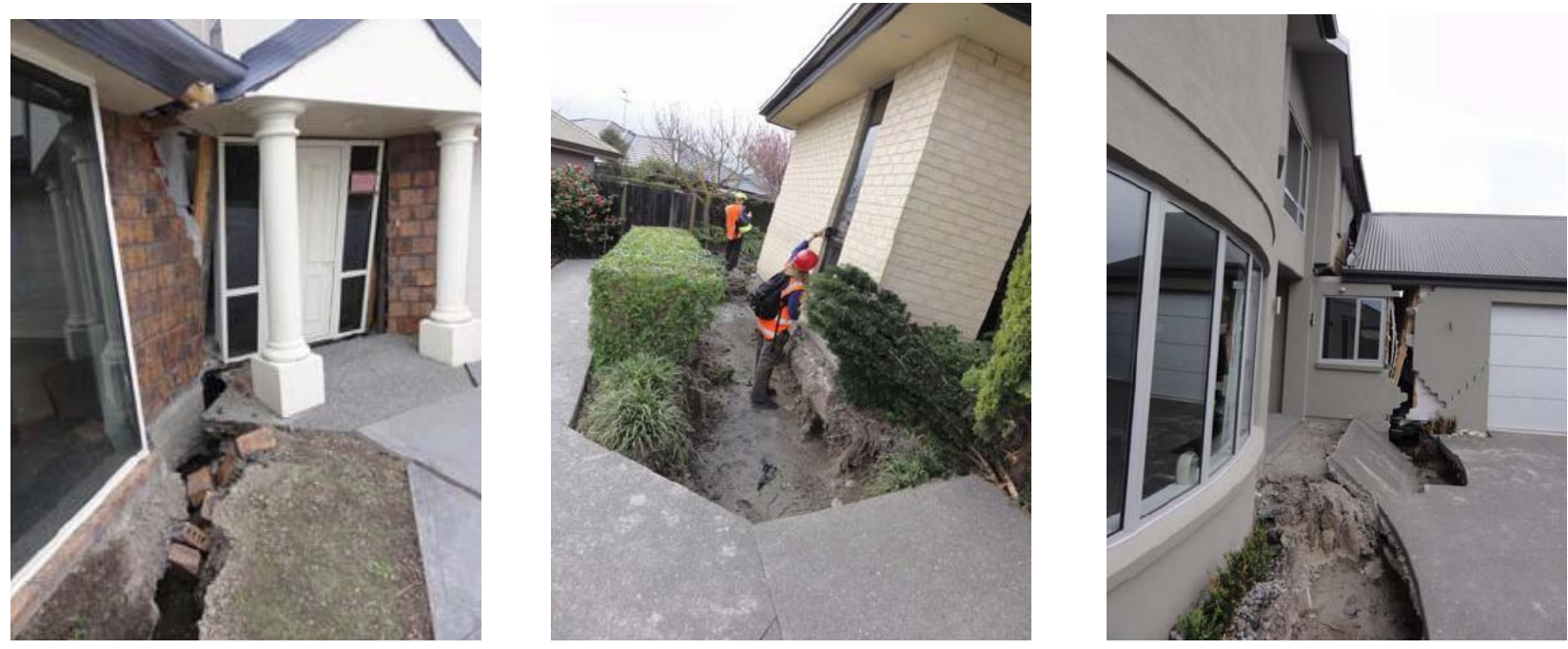

(b) Effects of lateral spreading in residential area.

Figure 4.34: $\quad$ Lateral spreading at Courtenay Dr, South Kaiapoi.
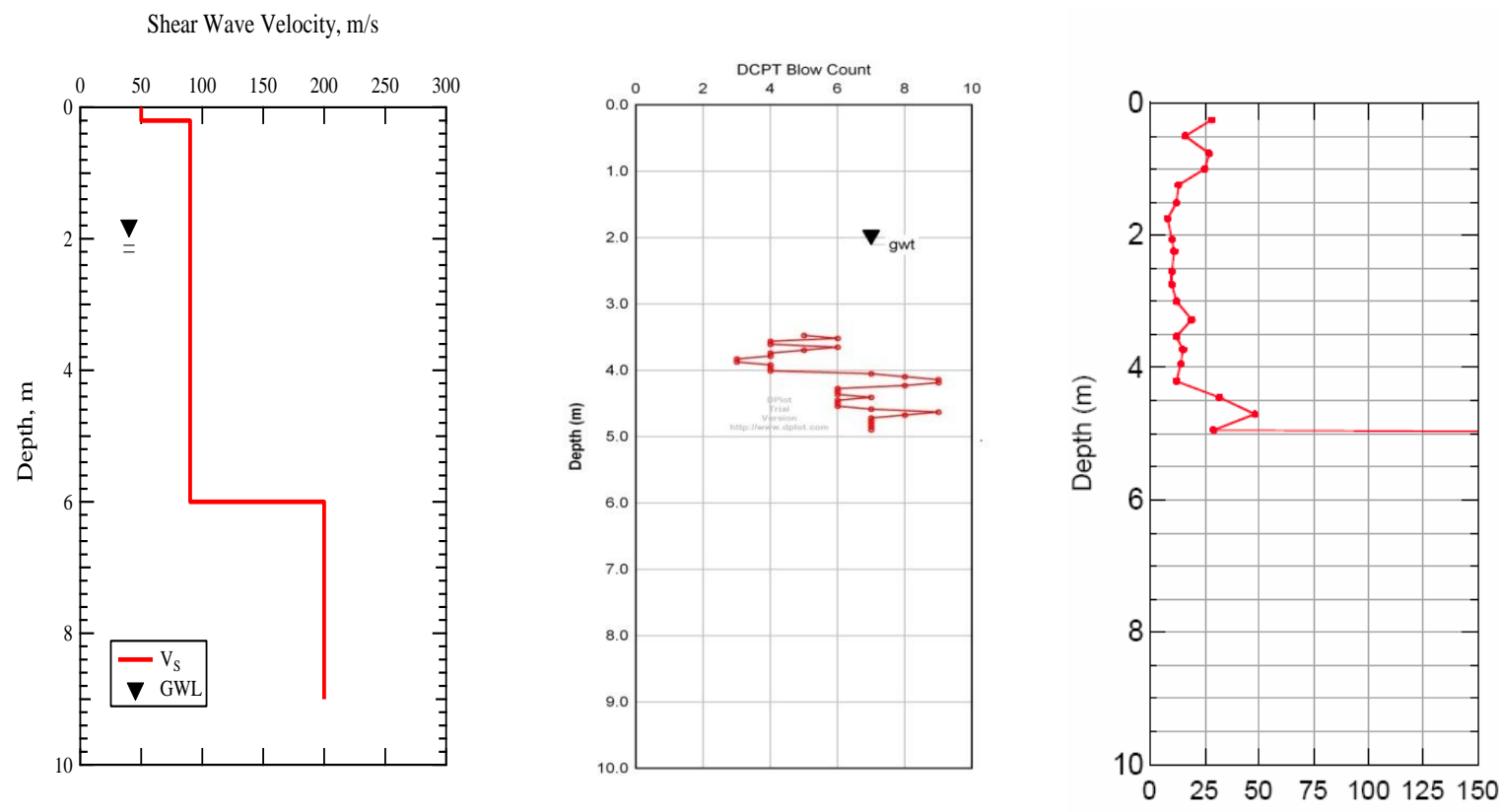

Number of half-rotations per meter, $\mathrm{N}_{\mathrm{SW}}$

Figure 4.35: Results of SAWS test, DCPT and SWS test performed at a residential property along Courtenay Dr. 


\subsection{Liquefaction associated with ejected gravel}

\subsubsection{Selwyn River near Greendale}

The Selwyn River traverses the Canterbury Plains flowing in a roughly south-easterly direction to the south of Christchurch and discharging into Lake Ellesmere.

At the evening meeting of Sunday, 12 September, Pilar Villamor of GNS reported to the team that she had seen liquefaction in a farm paddock at the Greendale end of the fault trace. The paddock was on the Selwyn Forks property which is accessed from the Hororata - Dunsandel Rd on the southern side of the Hororata and Selwyn rivers. The locations of the liquefaction are shown in Figure 4.36.

The NZ-GEER team visited the area on Monday, 13 September. On the evening of Sunday, 12 September, there had been heavy rain in the area, so on Monday the river channels were running high and the Hororata River was flowing in new areas because of a stopbank damage induced by the earthquake. The team first looked at end of Gillanders $\mathrm{Rd}$. on the Darfield side, and found an area with ground damage off the end of the track, close to one of the river channels (Figure 4.37, Photo 1, BX22 257725 (43 35' 48" S $\left.172^{\circ} 04^{\prime} 48^{\prime \prime} \mathrm{E}\right)$.
A short distance from here at the end of Gillanders Rd, the team found damage to the unsealed pavement and in the grass verge nearby. Evidence of liquefaction was seen (Figure 4.38, Photo 2, BX22 258726). Notable here was the fine gravel on the surface of the sand. Also note that rain had fallen the previous evening so the surface of the ejected material would have been altered somewhat.

The liquefaction was located on the Selwyn Forks property (map reference BX22 250727). Access was a little difficult because a farm creek was being fed from an errant tributary of the Hororata River. The liquefaction was distributed across several fields. Material was ejected from fissures in the ground which are likely to be lateral spreads given the stream channels nearby. The ejected material was topped off with a layer of coarse gravel (Figure 4.39). Figure 4.40 shows not only sand and gravel but also clods of topsoil. It is not clear if the gravel was part of the liquefied layer or was carried to the surface with the ejected sand. When questioned, Mr Ridgen suggested that the ground profile consisted of topsoil, gravel and then sand. If this profile is confirmed then the gravel is probably carried to the surface by the liquefied sand coming from below.

Further liquefaction has been reported up the Selwyn beyond the Selwyn Forks property. The team has not been able to confirm this by their own inspection.

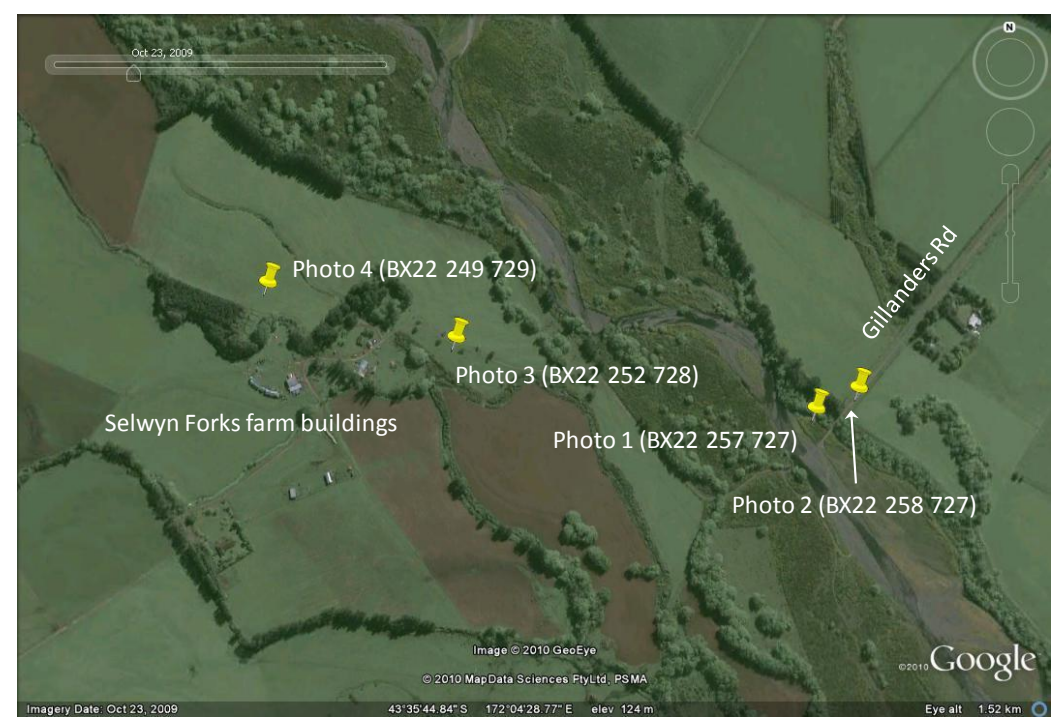

Figure 4.36: Location of the liquefaction along the Selwyn River in the Greendale region. (Date of Google image October 23, 2009).

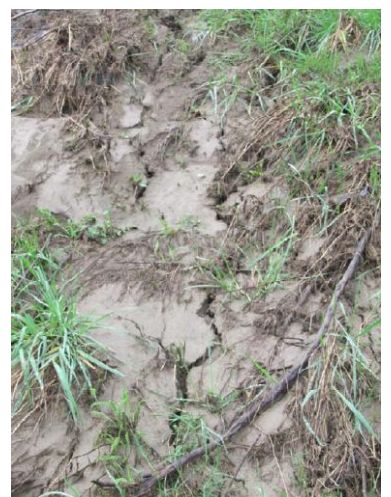

Figure 4.37: Ground damage adjacent to the bank of the Selwyn tributary near the end of Gillanders Rd (Darfield side). (Position marked as Photo 1 in Fig. 4.36).

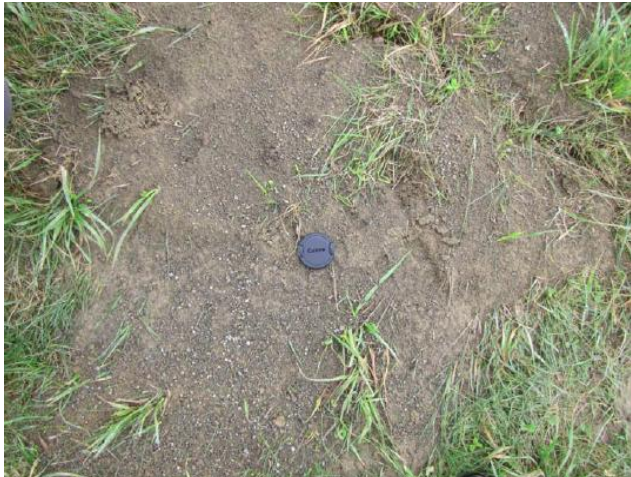

Figure 4.38: Liquefaction on the grass verge adjacent to the end of Gillanders Rd (Darfield side). Note the fine gravel particles on the surface and the fissure towards the top right hand side - it was possible to push the sampling spoon to a depth of about $300 \mathrm{~mm}$ into the fissure.

(Position marked as Photo 2 in Fig. 4.36). 


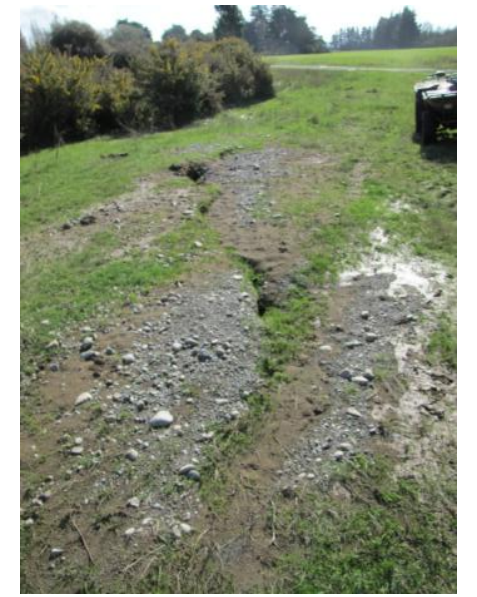

Figure 4.39: Material ejected from a fissure on the Selwyn Forks farm (front paddock). Note the gravel overlying the brown coloured sand. This is what was visible after a night of rain.

(Position marked as Photo 3 in Fig. 4.36).

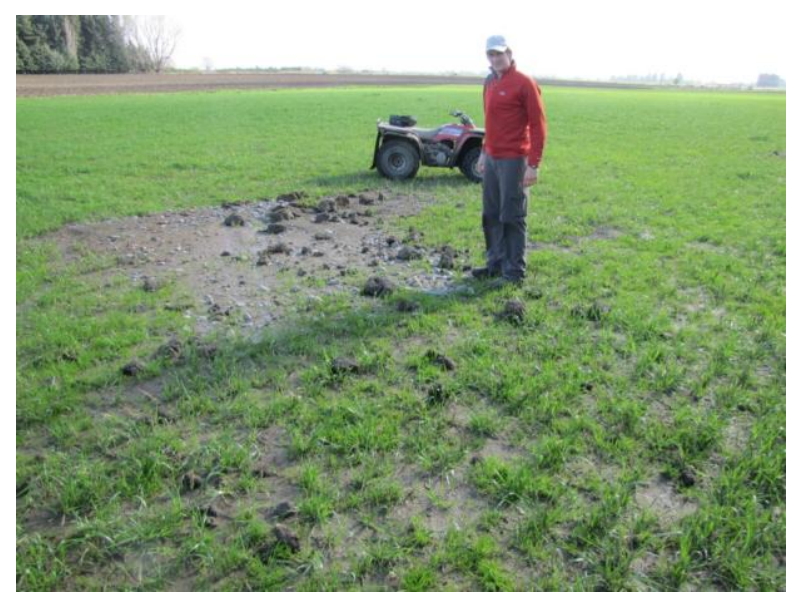

Figure 4.40: Ejected material on another paddock of the Selwyn Forks farm (Sheepyard paddock). As well as sand and gravel the ejecta contain clods of topsoil. (Position marked as Photo 4 in Fig. 4.36).

\subsubsection{Near Clearwater}

Liquefaction also occurred near the Clearwater development along Johns Road (43 $27^{\circ} 15.96^{\prime \prime} \mathrm{S}$ and $\left.172^{\circ} 35^{\prime} 42.89^{\prime \prime} \mathrm{E}\right)$. Figure 4.43 shows that gravel was ejected in addition to sand. There were a number of other instances of liquefaction in the open ground adjacent to the example illustrated in Figure 4.43.

Figure 4.42 shows the material ejected at the position labeled Photo 5 (Figure 4.41, Lincoln BX23 479626 (43 41' 17' S $\left.172^{\circ} 21^{\prime} 12^{\prime \prime} \mathrm{E}\right)$ illustrating that the material ejected consisted of sand with some gravel. Comparison of photos in Figures $4.39,4.40$ and 4.42, shows that the materials ejected at Selwyn Forks and at Willow Lea were similar.

The farmer at Willow Lea, Mr Mark Fleming, reported that the fissures he observed were at least $2 \mathrm{~m}$ deep based on probing with a length of number 8 fencing wire. He also explained that the width of the fissures had increased gradually since the earthquake and that the prominence of the ejected sand had decreased with time (the photograph in Figure 4.42 was taken on September 29). More instances of liquefaction have been reported on other properties further down the Selwyn River, but the team has not confirmed this by site visits.

\subsection{Most Distal liquefaction feature}

The most distal liquefaction features from the epicentre and fault rupture that the team members found or heard about are in Waikuku Beach, north of Kaiapoi along the coast, and in Akaroa, southeast of Christchurch on Banks Peninsula. The site-to-source distance to Akaroa is slightly more than to Waikuku Beach. The epicentral distance and closest distance to the fault rupture for the Akaroa site are $\sim 54$ and $44 \mathrm{~km}$, respectively. These distances are plotted in Figure 4.44, along with data from worldwide earthquakes compiled by Ambraseys (1988). As may be observed from this figure, the epicentral distance falls well within the boundary for maximum distance, but the closest distance to the fault rupture is close to the boundary formed by data from other earthquakes.

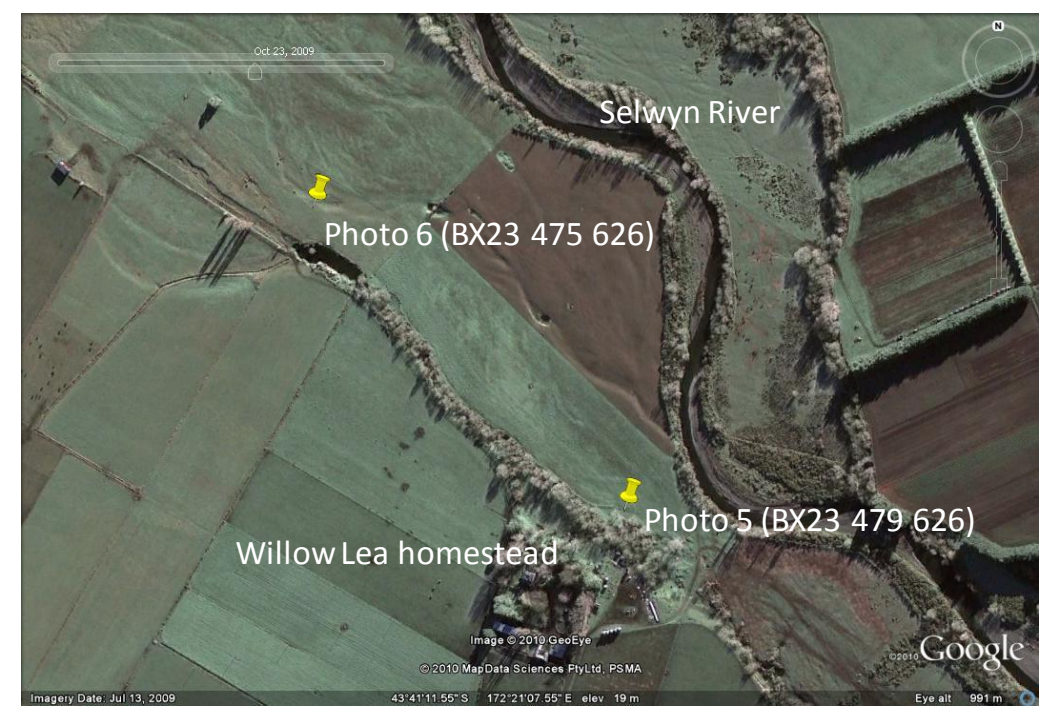

Figure 4.41: Location of the liquefaction along the Selwyn River in the Irwell region. (Date of Google image July 13, 2009). 


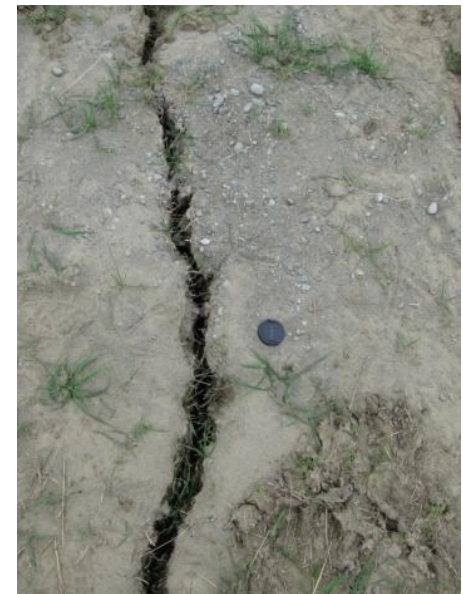

Figure 4.42: $\quad$ Ejected sand and gravel at the Willow Lea property (position marked as Photo 5 in Fig. 4.41).

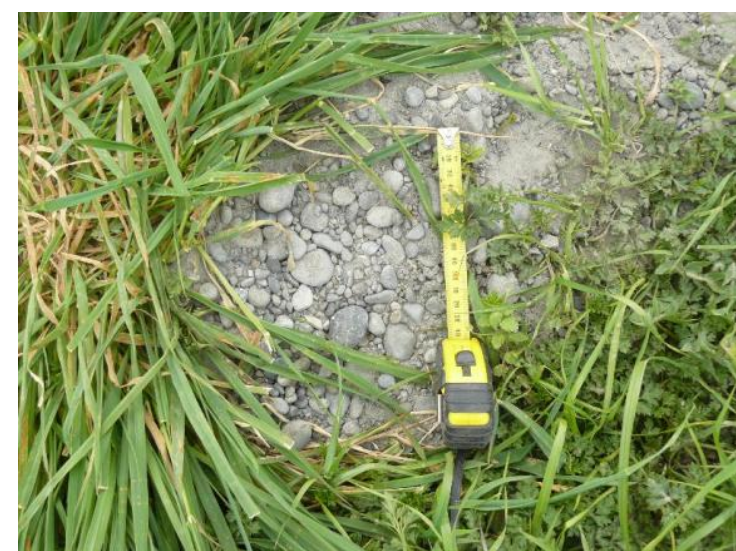

Figure 4.43: Ejected sand and gravel in the Clearwater area (photo by Ian McCahon).

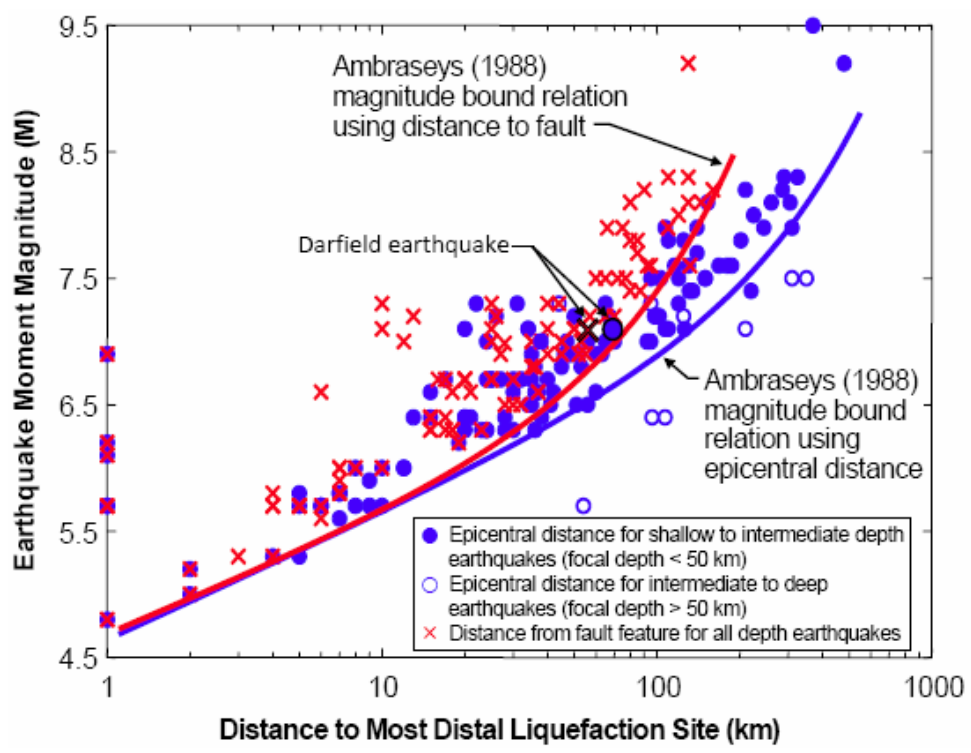

Figure 4.44: Comparison of the most distal liquefaction feature from the Darfield Earthquake with worldwide earthquake data collected by Ambraseys (1988). (Adapted from Rathje et al., 2010).

\section{IMPACT ON BUILDING STRUCTURES}

\subsection{General}

Major impacts to building structures during the Darfield event of September 4, 2010 were related to unreinforced masonry or brick (URM) buildings and residential areas where ground failure below or nearby the foundation was observed. Modern structures supported on stable ground in general performed well. Many URM and brick structures, particularly in the Christchurch business district, suffered complete or partial collapse due to strong shaking (e.g. Figure 5.1). All of these structures were under 3 stories, with most being 1-2 stories (about 70\%). Of the 595 URM buildings in Christchurch surveyed by city inspection teams immediately following the earthquake, $21 \%$ were assigned usability ratings of red, $32 \%$ yellow, and 47\% green (Moon, 2010; Ingham and Griffith, 2010). The structural damage to URM and brick buildings, where ground failure was not observed, is being documented by the EERI and other post-earthquake reconnaissance teams. Interested readers should consult their reports for comprehensive documentation of the structural performance of buildings where ground failure did not impact performance.

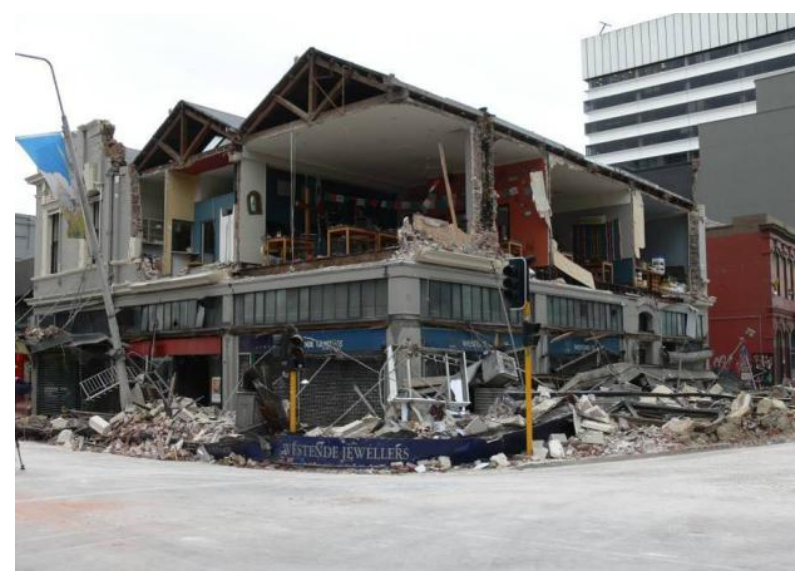

Figure 5.1: Structural collapse of a URM in the Christchurch Business District. (184 Manchester Street). Photograph courtesy of Assoc-Prof Jason Ingham. 
Ground failure including liquefaction and lateral spreading resulted in extensive damage to both new and old construction, impacting houses, light commercial, school and church buildings within neighbourhoods. The most prevalent type of damage included extensive subsidence, tilting, and separation of the structural components of the building. Importantly lateral spreading ground was observed to have detrimental impact on light residential construction. Slab foundations did not provide sufficient restraint of the ground movement to preclude extensive structural separation in many situations where excessive ground spreading features were observed. In this chapter of the report, several important cases that provide insight regarding the effects of ground failure on buildings are documented.

\section{$5.2 \quad$ Kaiapoi area}

\subsubsection{Kaiapoi small business area}

Small businesses line the fronts of Charles Street paralleling the Kaiapoi River from approximately Jones St to Davie St (Figure 5.2). The vintage of these structures vary, however, most are single or 2 stories and constructed of light wood framing with brick façade, or stucco, or solely of concrete masonry block. Extensive lateral spreading parallel to the Kaiapoi River extended into the small business and residential regions impacting numerous structures within this community. Liquefaction was evident beyond the lateral spread as discussed in Chapter 4. The most severe damage to structures within the small business community along Charles Street is shown in Figures 5.3-5.9. The Gospel Way church for example, a single storey structure of brick construction, suffered separation of its heavy front structure from its orthogonal support walls due to lateral movement of the ground towards Charles Street (Figures 5.3-5.5). The large lateral ground spreads extended northeast along the longitudinal axis of the building as evident in the adjacent parking area (Figure 5.4). This ground movement manifested into distinct shear cracks at the brick-mortar joints (Figure 5.5a). Structural separation such as that evident in Figure 5.5a was visible at several distinct locations extending along the longitudinal axis of the building. The most severe damage was evident at the front of this building, which settled approximately $150 \mathrm{~mm}$, while the eastern length of the building remained approximately level (Figure 5.5b).
A small shopping area neighbouring the New World supermarket in Kaiapoi (between Williams and Jones streets north-south and Sewell and Charles streets east-west) showed patterns of extensive ground damage and resulted in many business closures (Figure 5.6a). Closures were primarily prompted by extensive hardscape and interior flooring damage (Figure 5.6b). These buildings attached units of one storey wood framed construction supported on slabs on grade and with glass front (open) facing as is common of walking business districts. The tallest structure to suffer damage in the direct adjacency to these business units was a red-tagged 3storey property and family law office constructed of concrete masonry block units (CMU) (Figures 5.7-5.8). This structure is rectangular in footprint with little to no lateral resistance along the longitudinal axis of the building (as evident from the perimeter full facing glass openings - Figure 5.7a). The short axis of the building provides resistance to lateral movement and loads via stiff full length CMU walls at exterior ends of the structure (Figure 5.7b). The front of this building appeared to have settled and rotated towards the direction (southwest) (Figure 5.8). Lateral spread ground failure and liquefaction ejecta were evident directly adjacent to this building (Figure 5.9). A sample of material taken adjacent to this building was tested using laser diffraction scanning (Figure 5.10, denoted WP24).

Movement of the Kaiapoi wharf resulted in damage to the historic Kaiapoi Railway Station, which is now renovated and used as the Kaiapoi Information Centre $\left(43.3838^{\circ} \mathrm{S}\right.$, $\left.172.6596^{\circ} \mathrm{E}\right)$ and its neighbouring Harbour Building $\left(43.3834^{\circ} \mathrm{S}, 172.6591^{\circ} \mathrm{E}\right)$. The Kaiapoi Information Centre building is a renovated wood framed building on an elevated foundation (Figure 5.11). As a result of loss of ground support, this building tilted approximately 5 degrees northeast (away from the river). Rapid stabilization of the building had been complete by the time of the NZ-GEER team visit on 11 September 2010 in the form of concrete footings poured on the exposed (near river) foundation side of the building (Figure 5.11b). In addition, tension tie-backs anchored from newly poured concrete footings to a patio area were used to stabilize the upper pavement during the continuing ground movement. The Harbour building is a one-storey masonry block building that suffered tilting towards the river and separation from the wharf of approximately $150-250 \mathrm{~mm}$ on its west face (Figure 5.12).

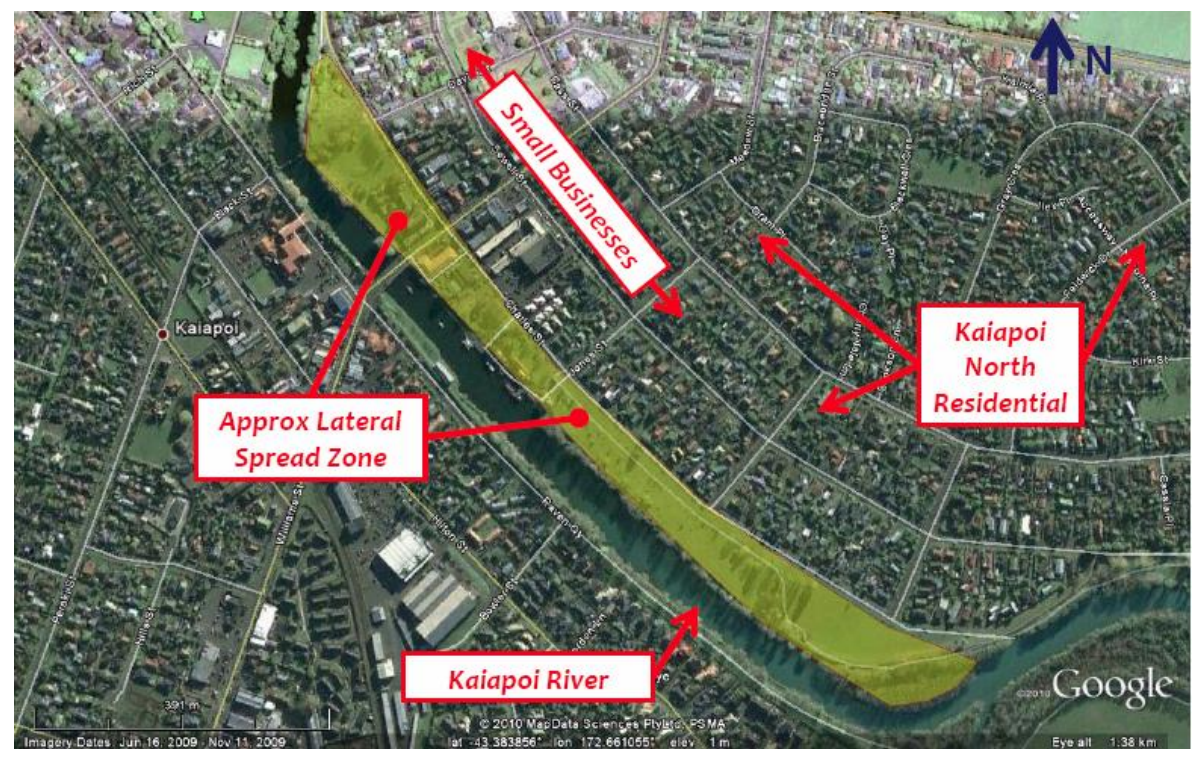

Figure 5.2: $\quad$ Kaiapoi North residential and small business region. Annotated GoogleEarth image. 


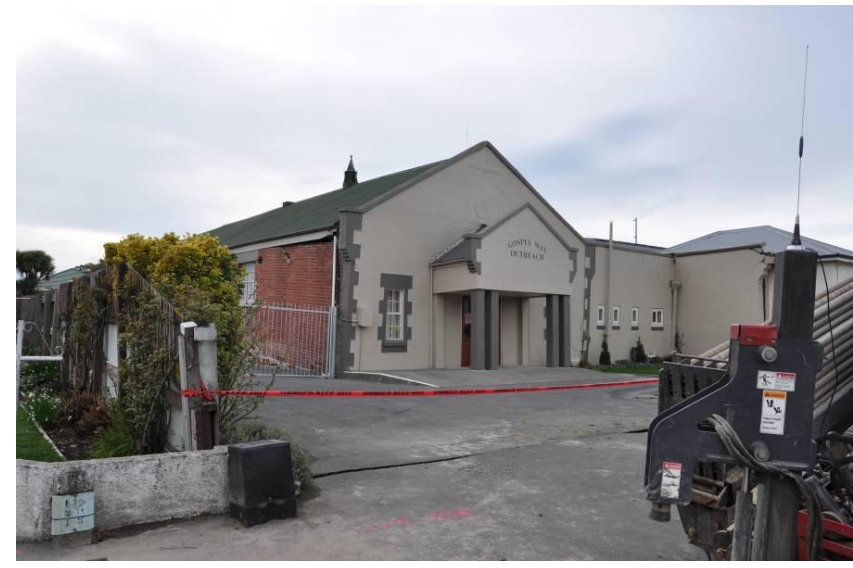

Figure 5.3: $\quad$ Front facing (view looking northeast) of the Gospel Way church in Kaiapoi along Charles Street.

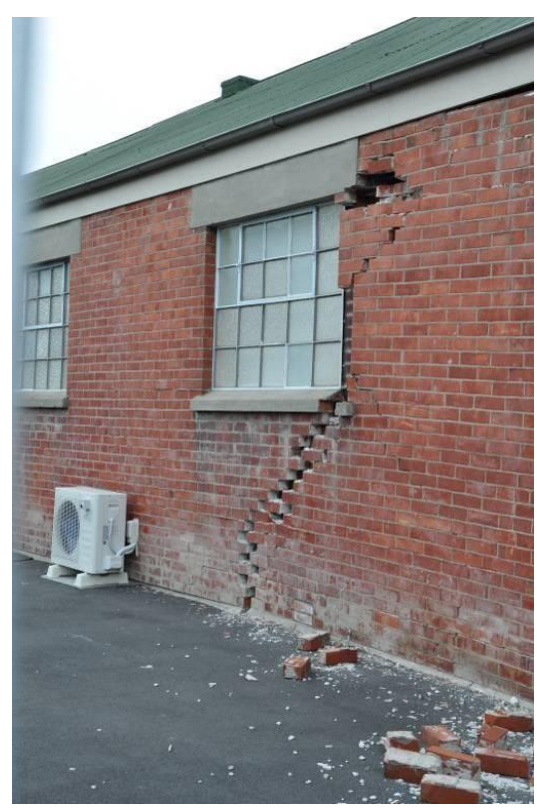

(a)

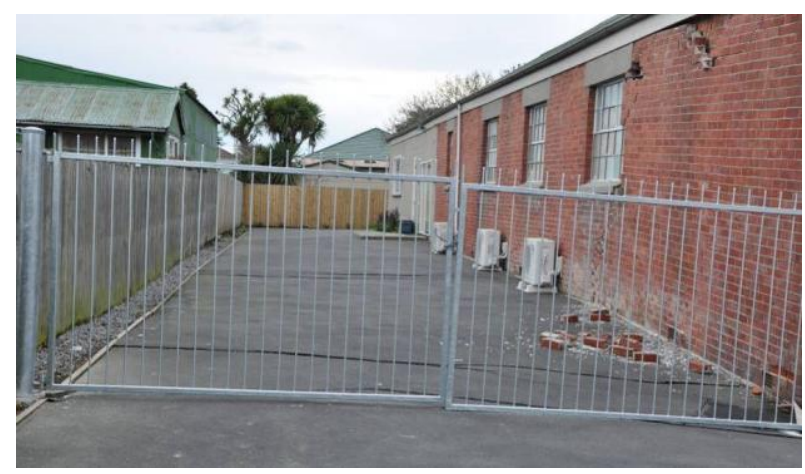

Figure 5.4: $\quad$ Lateral spread patterns extending east along the longitudinal axis of the Gospel Way church in Kaiapoi along Charles Street.

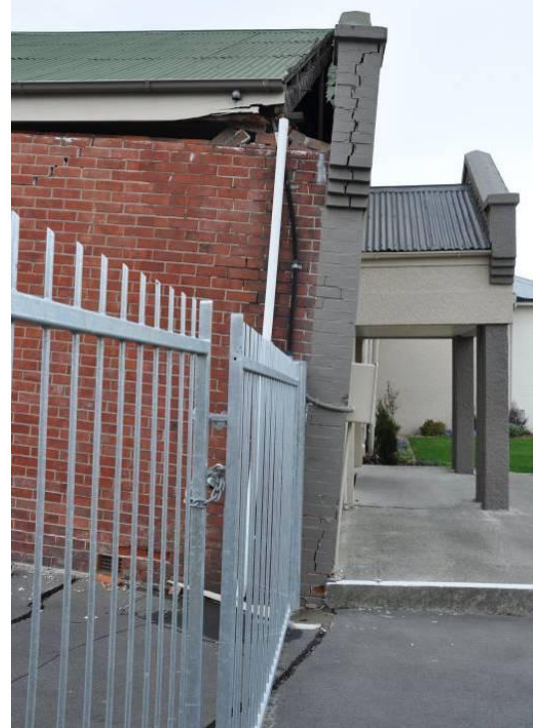

(b)

Figure 5.5: Gospel Way Church in Kaiapoi: (a) Shear crack pattern developed at brick-mortar joints along the northern side of the building and (b) separation (settlement and rotation) of the west face of the building.

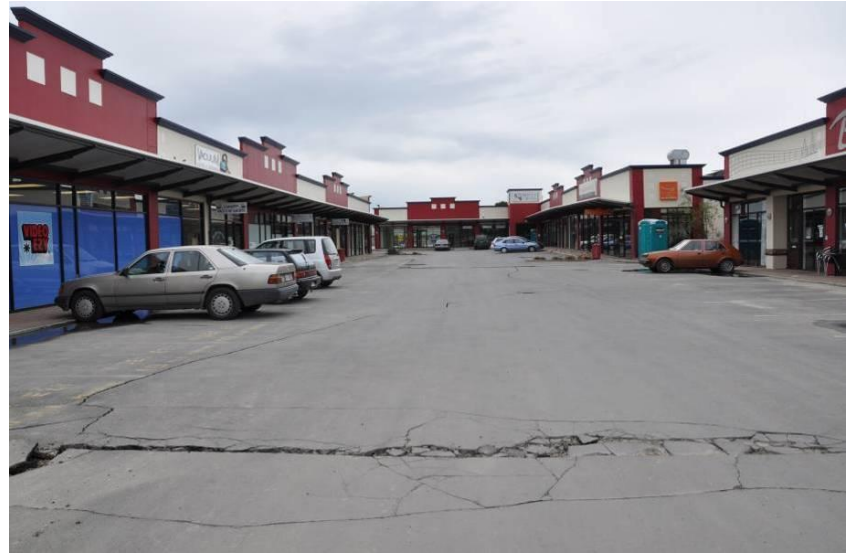

(a)

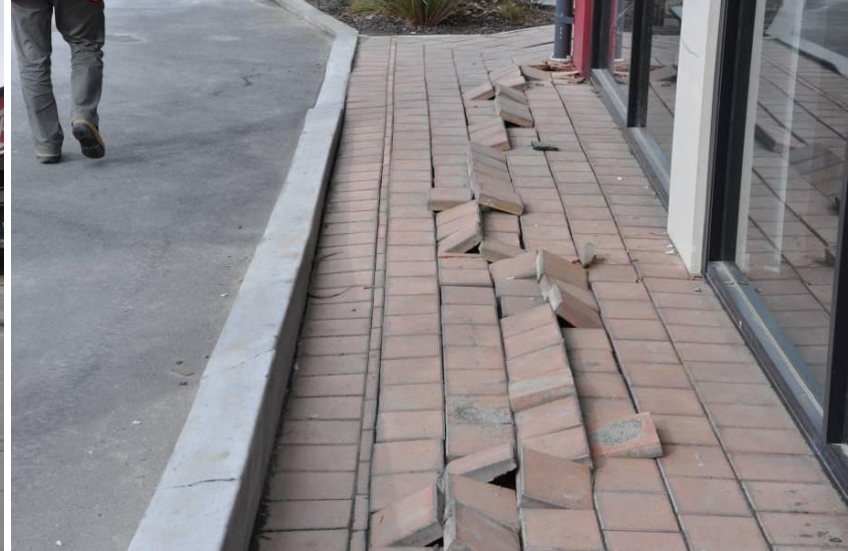

(b)

Figure 5.6: $\quad$ Small business attached units neighbouring the New World supermarket in Kaiapoi (Charles St). (a) View looking east showing ground damage pattern and (b) resulting hardscape damage at the front of one business unit. 


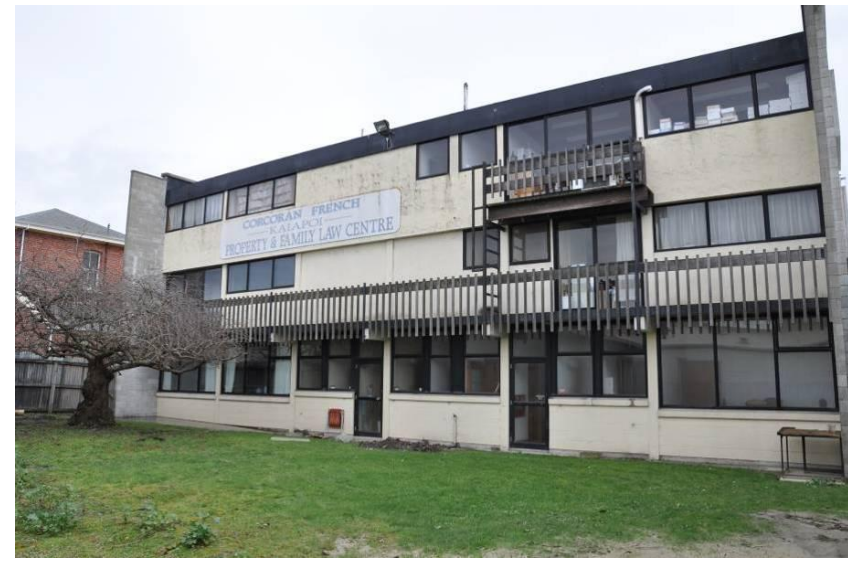

(a)

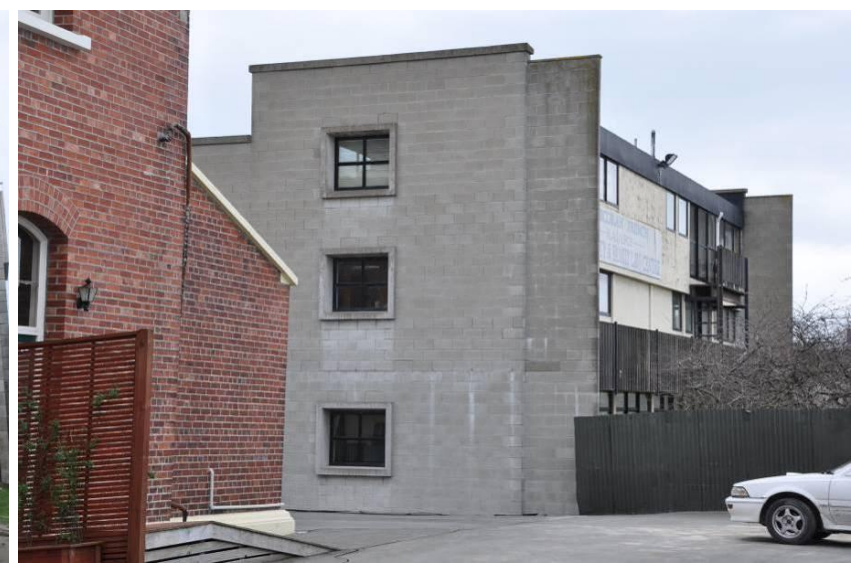

(b)

Figure 5.7: $\quad$ Property and Family Law Offices in Kaiapoi business district. (Williams St.) (a) View looking northwest (at long axis end) of building and (b) view looking northeast showing shear wall ends of short axis of building.

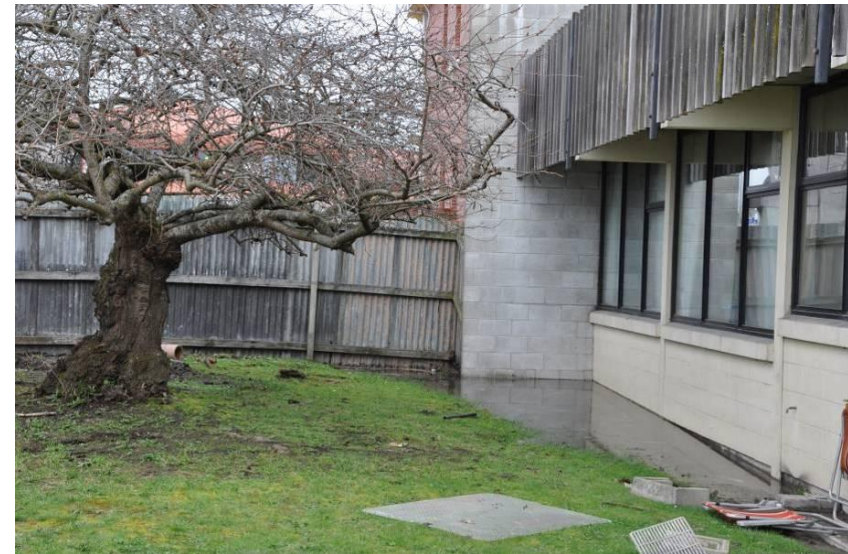

Figure 5.8: $\quad$ Property and Family Law Offices in Kaiapoi business district. (Williams St). View looking at west short axis end of the building.
North of the Kaiapoi Information Centre and Harbour Buildings, a two storey wood frame building with subterranean parking (nearest to river) and a full floor level (nearest to Charles Street) currently housing the Bridge Tavern building was extensively damaged due to ground movement (Figure 5.13). Although movement of the retaining wall adjacent to the Kaiapoi River was not evident, the east embankment side, which supported the first storey subterranean parking area showed evidence of ground settlement and cracking. This damage precipitated movement of columns supporting the upper storey of the building (Figure $5.13 b)$.

Soil samples taken from the largest visible ground ejecta features within the park adjacent to the Kaiapoi River liken the material to that observed within the small business district of Kaiapoi (Figure 5.10). These grain size distribution curves indicate the material directly adjacent to the wharf and likely extending into the neighbouring park is a uniformly graded sandy soil with about $10 \%$ fines (Table 5.1). In contrast material further from the rivers' edge (e.g. WP24 taken within the small business district of Kaiapoi) although similarly sandy and uniformly, graded contains a more appreciable amount of fines (30\%). The largest content of fines of these samples approached 70\% (WP169 taken at the Lyttelton Oil Terminal)

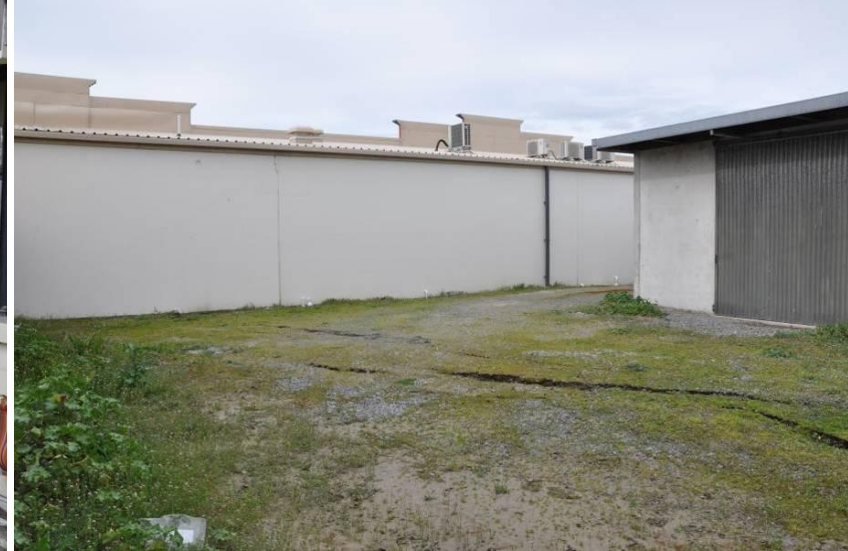

Figure 5.9: $\quad$ Surrounding ground failure patterns directly adjacent to the Property and Family Law Offices in Kaiapoi business district. View looking southeast.

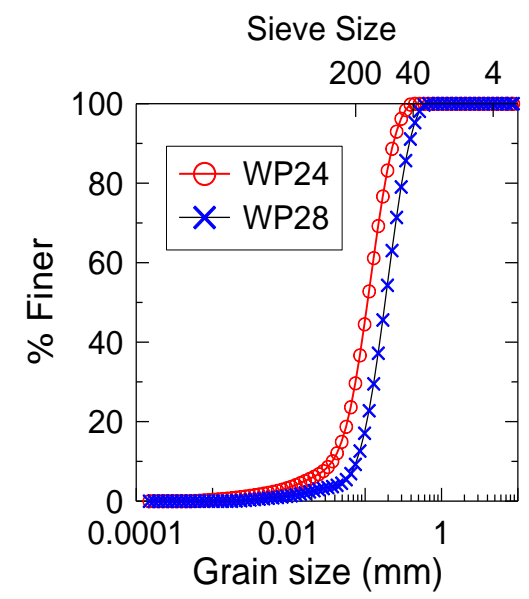

Figure 5.10: Grain-size distribution of samples taken from ejecta observed in Kaiapoi area (sample taken 11 September 2010 testing via laser diffraction). Sample WP24 taken at $43.381856^{\circ} \mathrm{S}, 172.659149^{\circ} \mathrm{E}$ (adjacent to law offices) and sample WP28 taken at $43.384723^{\circ} \mathrm{S}, \quad 172.661314^{\circ} \mathrm{E}$ (adjacent to Kaiapoi wharf). 
Table 5.1 Summary of laser diffraction testing results

\begin{tabular}{|c|c|c|c|c|c|c|c|c|}
\hline WP & Location & GPS Coordinates & \%Fines & $\begin{array}{c}\text { D10 } \\
(\mathrm{mm})\end{array}$ & $\begin{array}{c}\text { D30 } \\
(\mathbf{m m})\end{array}$ & $\begin{array}{c}\text { D60 } \\
(\mathrm{mm})\end{array}$ & Ce & $\mathbf{C u}$ \\
\hline WP24 & Kaiapoi business & $\begin{array}{l}43.3819 \mathrm{~S}^{\circ} \\
172.6591 \mathrm{E}^{\circ}\end{array}$ & 30 & 0.037 & 0.075 & 0.129 & 1.179 & 3.486 \\
\hline WP28 & Kaiapoi adjacent to wharf & $\begin{array}{l}43.3847^{\circ} \mathrm{S}, \\
172.6613^{\circ} \mathrm{E}\end{array}$ & 10 & 0.075 & 0.129 & 0.214 & 1.038 & 2.851 \\
\hline WP104 & Bexley Residential & $\begin{array}{l}43.5190^{\circ} \mathrm{S}, \\
172.7202^{\circ} \mathrm{E}\end{array}$ & 10 & 0.075 & 0.127 & 0.185 & 1.168 & 2.463 \\
\hline WP169 & Lyttelton Oil Terminal & $\begin{array}{l}43.6088^{\circ} \mathrm{S}, \\
172.7142^{\circ} \mathrm{E}\end{array}$ & 70 & 0.023 & 0.042 & 0.065 & 1.164 & 2.813 \\
\hline
\end{tabular}

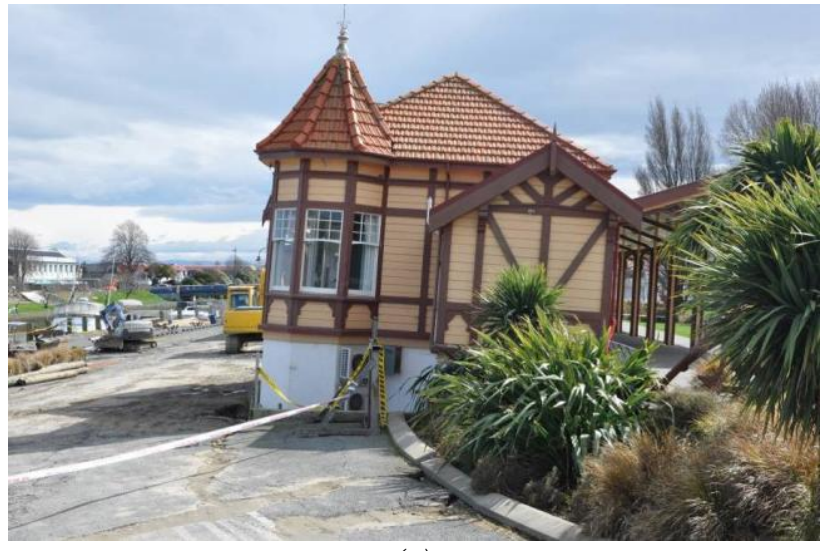

(a)

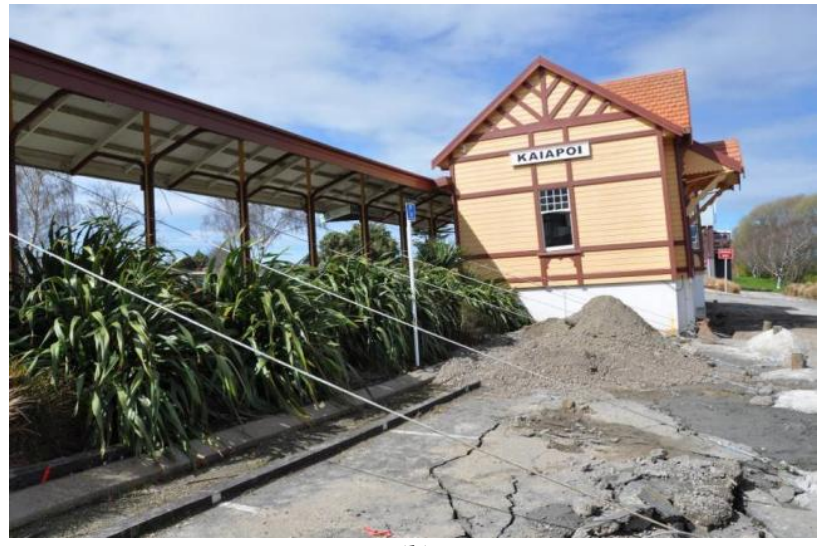

(b)

Figure 5.11: Renovated Kaiapoi Railway building now used the Kaiapoi Information Centre, adjacent to the Kaiapoi Wharf. (a) View looking northwest and (b) view looking southeast (note the temporary elevated patio support tie-backs and newly poured footings at the front (river side) of the building.

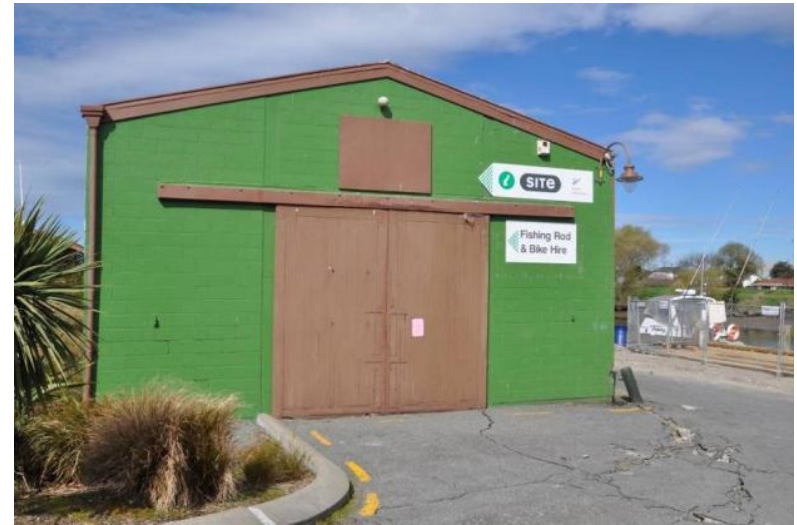

(a)

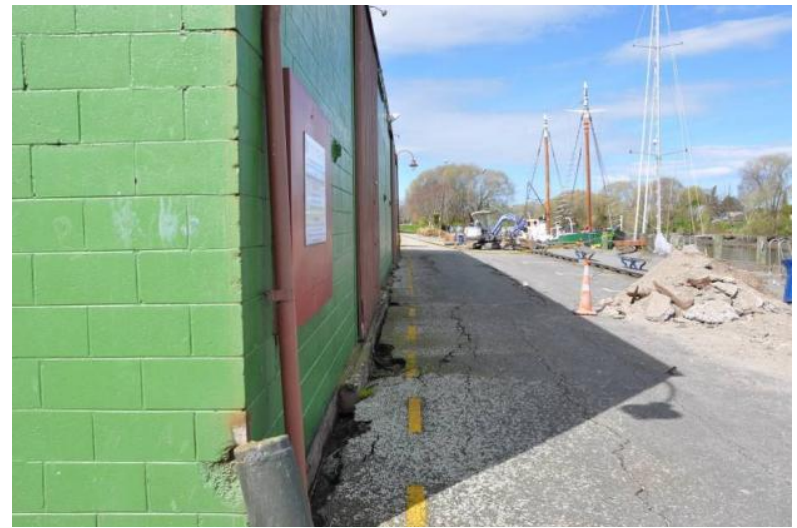

(b)

Figure 5.12: Harbour building adjacent to the Kaiapoi River and wharf structures. (a) View looking southeast and (b) view of the northwest corner of the building. Note the approximate 150-250 $\mathrm{mm}$ gap between the pavement and building. 


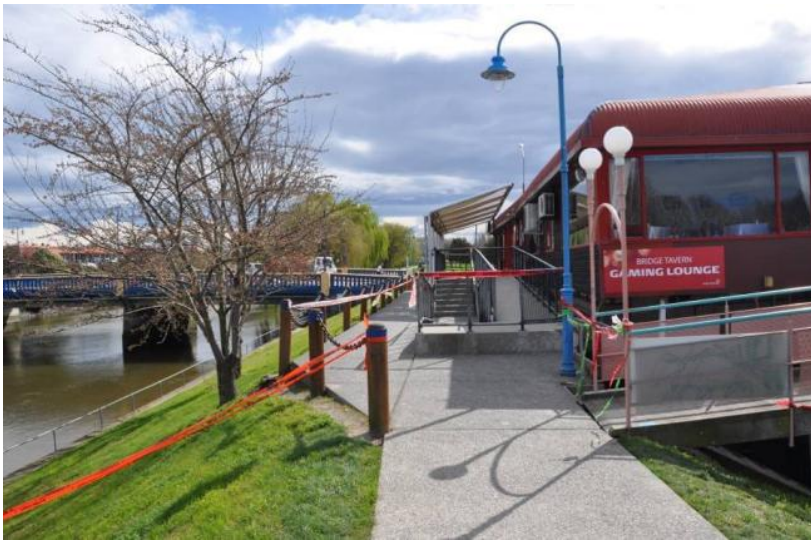

(a)

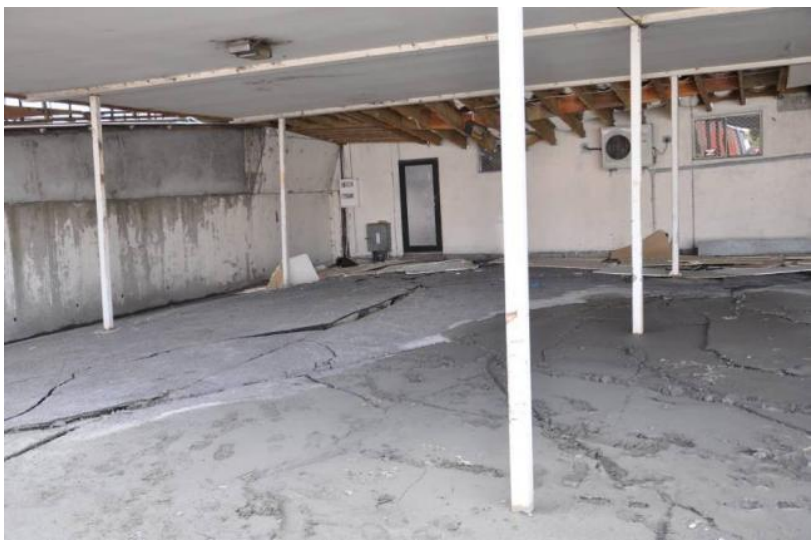

(b)

Figure 5.13: Bridge Tavern adjacent to the Kaiapoi River. (a) view looking northwest at Williams Street bridge and (b) view looking northwest at subterranean parking.

\subsubsection{Kaiapoi residential}

The most severe structural damage to houses in the Kaiapoi residential neighbourhoods was evident along Charles Street paralleling the Kaiapoi River (Kaiapoi North) as well as along Courtenay Drive, which parallels a branch of the Courtenay Stream (east of Kaiapoi South) (Figure 5.14).

Kaiapoi North - Residential construction within the Kaiapoi North community consists of 1-2 storey wood or concrete block framed homes. A number of homes are also constructed of brick or wood with brick façade units. The vintage of these homes appeared to extend as early as 1960 s construction, to more recent completely rebuilt or remodelled homes. Uniform settlement of the heavier brick constructed residential homes in this area, such as shown in Figure 5.15, were measured as large as $200-250 \mathrm{~mm}$.
Brick homes consistently observed shear cracking, discontinuities between window and door openings and brick, popped out and/or damaged glass windows, and damage to floor slabs and hardscape (Figure 5.16). Homes along Charles Street at the time of the NZ-GEER team visit (11 September 2010) were either red or yellow tagged. Very few homes were occupied, with most suffering extensive sand ejecta surrounding the home as well as settlement. In a number of cases, residents of severely damaged homes had moved out completely (e.g. Figures 5.17-5.18). This house at Charles Street experienced approximately $0.4 \mathrm{~m}$ of settlement along its North face (Figure 5.17b). Sand ejecta were present surrounding most homes along Charles Street and extending east into the North Kaiapoi residential area approximately 0.5 $\mathrm{km}$.

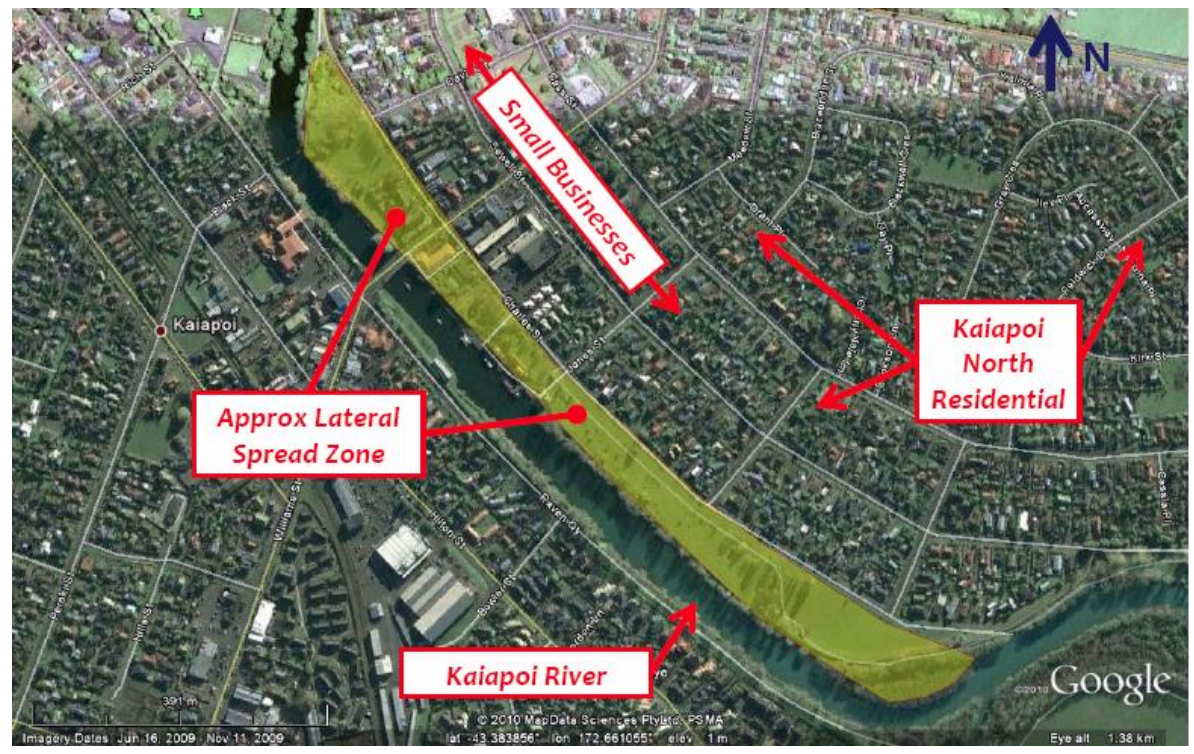

Figure 5.14: Kaiapoi North residential and small business region. Annotated GoogleEarth image. 


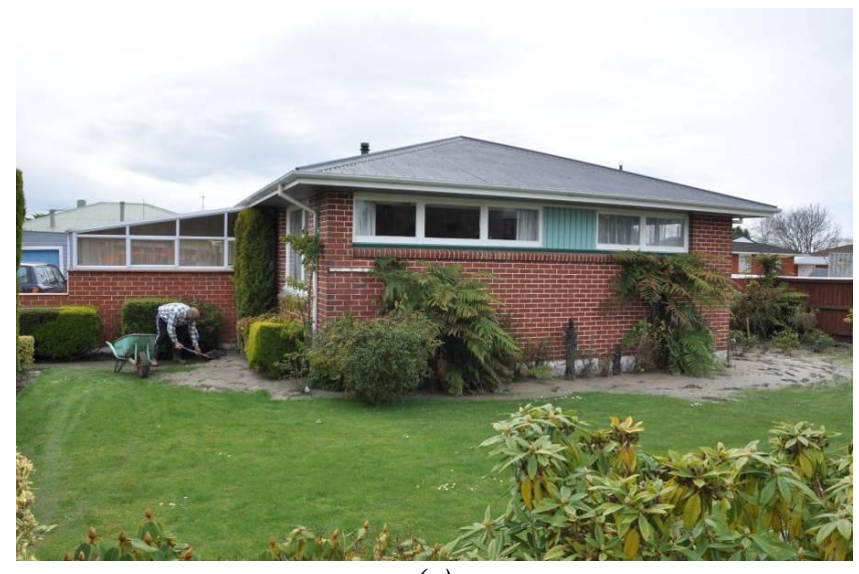

(a)

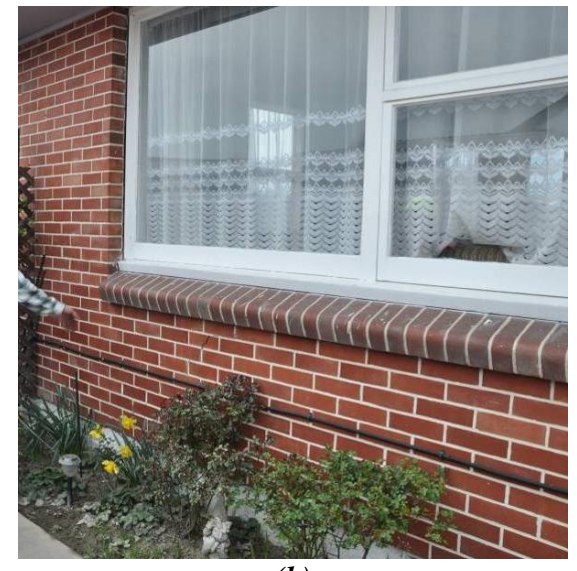

(b)

Figure 5.15: Residence along Charles Street. (a) Ejecta surrounding home and (b) owner points out shear cracking and gapping developed between window and brick due to structures movement.

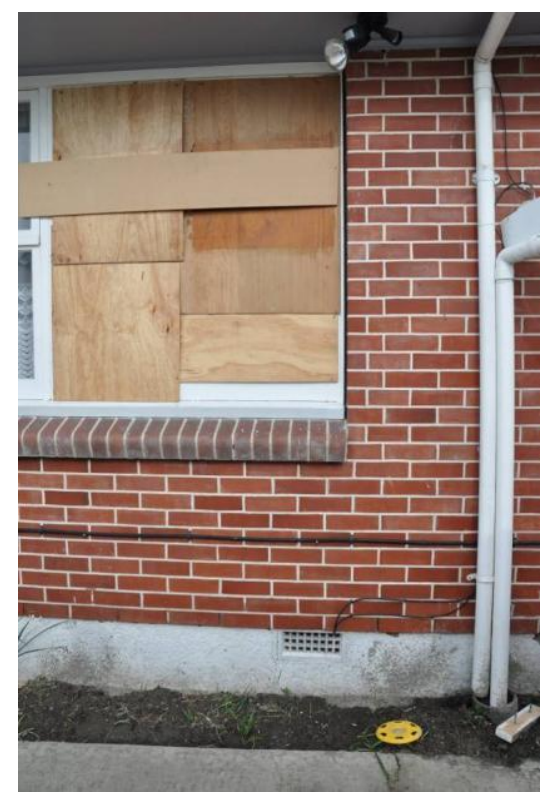

Figure 5.16: Residence along Charles Street (same structure as Figure 5.16). Damage to glass windows and between window and wall.

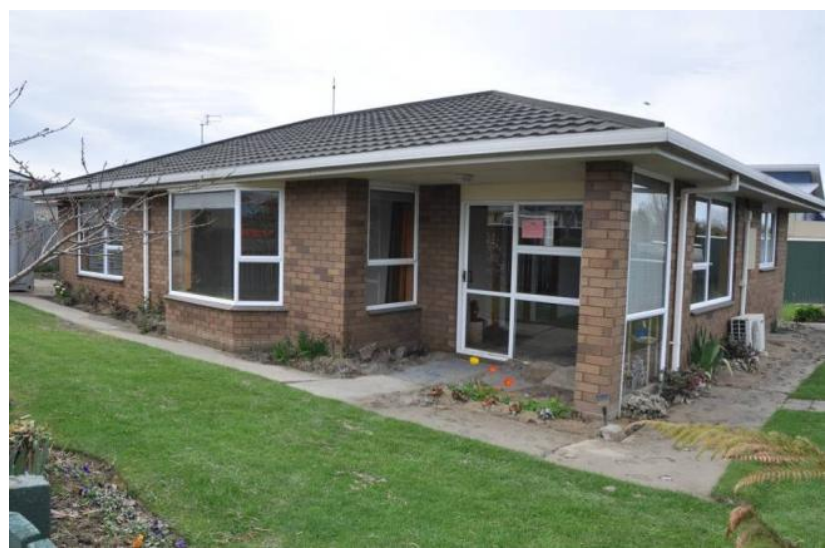

(a)

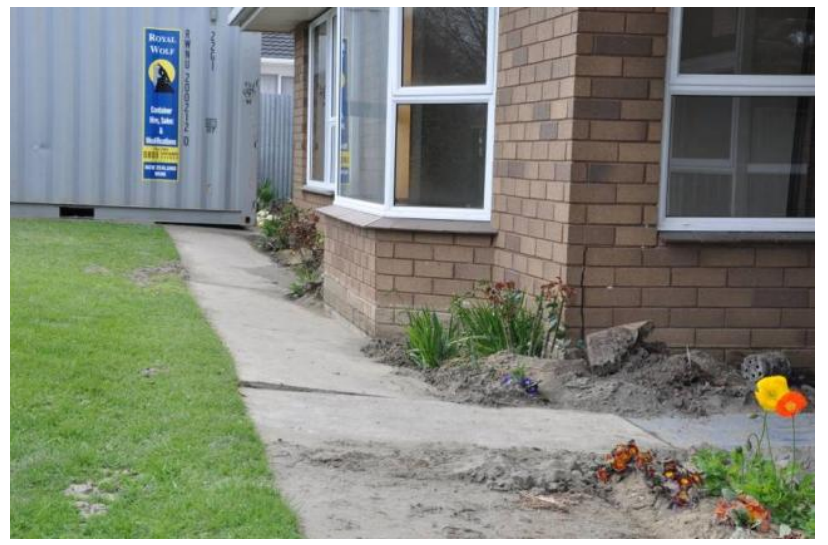

(b)

Figure 5.17: Red tagged residence on Charles Street. (a) View looking east and (b) north end of house, view looking North-East. 


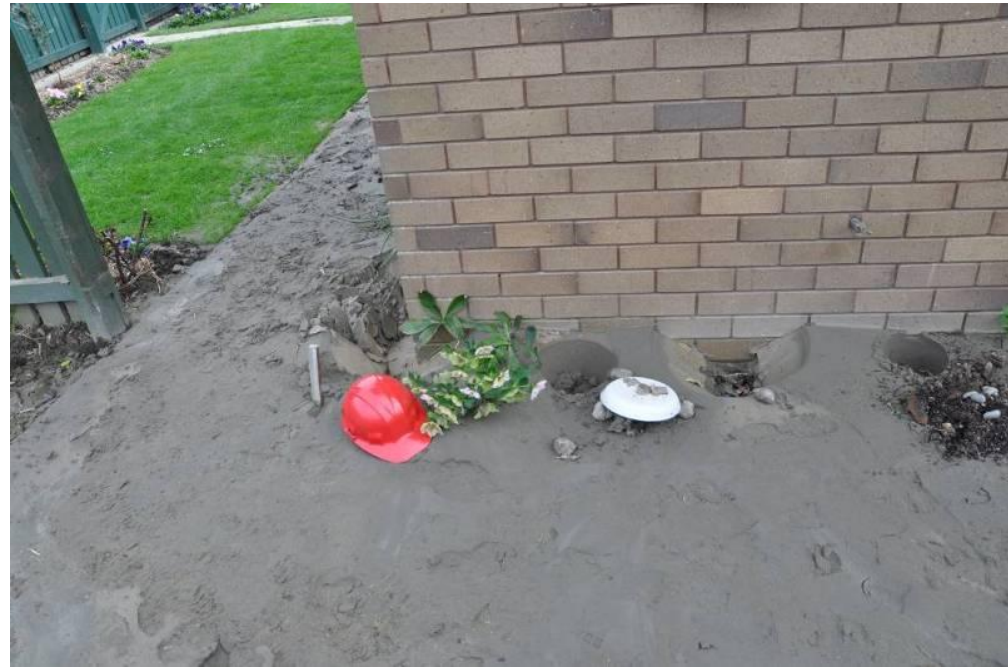

(a)

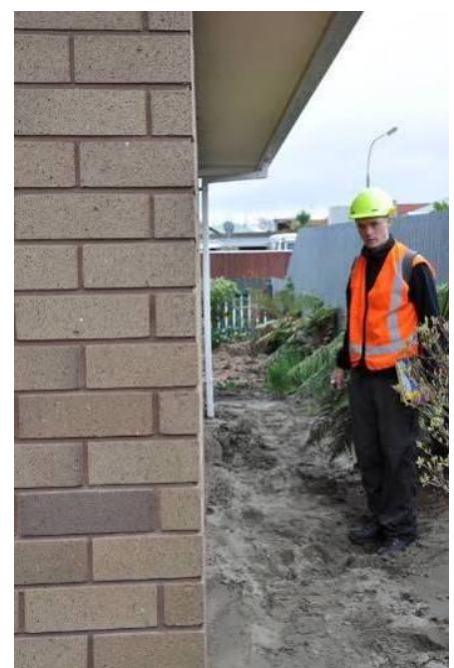

(b)

Figure 5.18: Red tagged residence on Charles Street. Extensive surrounding ejecta at perimeter of home.

Kaiapoi South - In general damage to building structures in the Kaiapoi South community was limited to Courtenay Drive between Kaikanui Street and ending at Parish Lane. This is a residential neighbourhood with relatively new homes, all constructed within the last ten years. Most homes are onestorey light wood framing or brick supported on unreinforced slabs with perimeter stemwall foundations and light metal roofing. An example of the typical construction style in this area is shown in Figure 5.19. Liquefaction was reported to inundate the neighbourhood north of Courtenay Drive towards Charters Street, however much of this had been cleaned up by the time of the NZ-GEER team visit and appeared to have minimal impact on the homes. The impact to homes along Courtenay Drive however, and particularly those on the east side of the drive, with direct facing to a paddocks' field as well as a branch of the Courtenay Stream, was extensive. Ground failure in this region manifested in large lateral spread zones coupled with liquefaction (Figure 5.20).

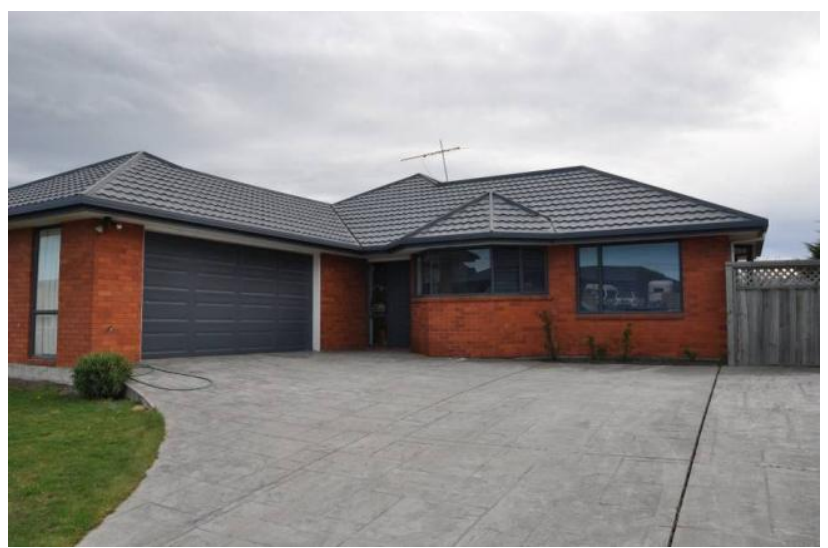

Figure 5.19: Typical construction style of homes along Courtenay Drive in the South Kaiapoi residential community.
A manual survey by the NZ-GEER team indicated that of the 44 homes along this drive $48 \%$ suffered severe structural damage induced by ground failure, while $15(36 \%)$ suffered moderate and minor damage, respectively. Laterally spreading ground was observed to extend through the backyards of these homes, with the lack of reinforcement within slab foundations and general light construction styles resulting in severe separation of the home directly in-line with the ground failure. The residences shown in Figures 5.21-5.24 demonstrate the observed damage due to excessive ground movement. The structure shown in Figures 5.21-5.22 suffered excessive tilting and a separation of $1.5 \mathrm{~m}$ from its approach driveway to the front of the home (Figure 5.22a), while the rear of the home collapsed inward due to surrounding ground fissures (Figure 5.22b). Similarly, the residence in Figures 5.23-5.24 articulated little to no damage at the backside of the home (Figure 5.23), however the front entry of the home at the interface between the garage and main portion of the residence suffered a separation of about $1 \mathrm{~m}$ due to lateral ground movement (Figure 5.24).

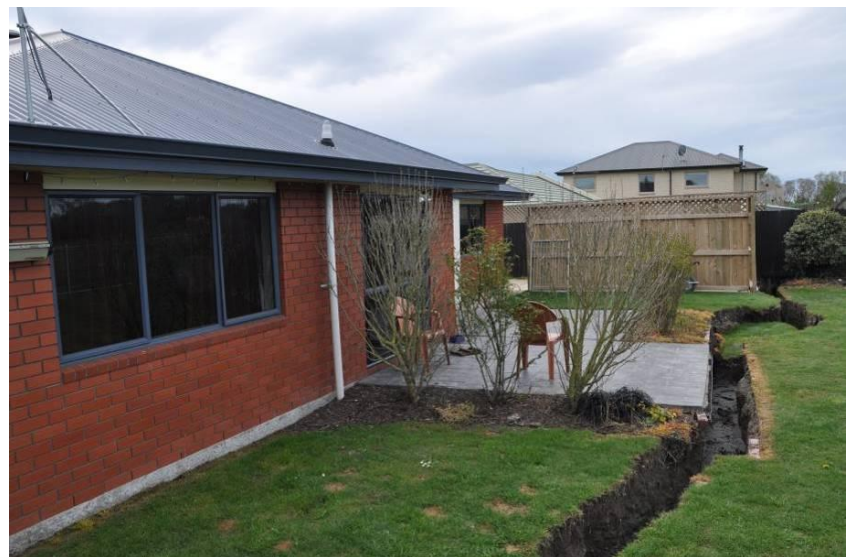

Figure 5.20: Ground failure feature extending through the backyard of a home on the south side of Courtenay Drive in the South Kaiapoi residential community. 


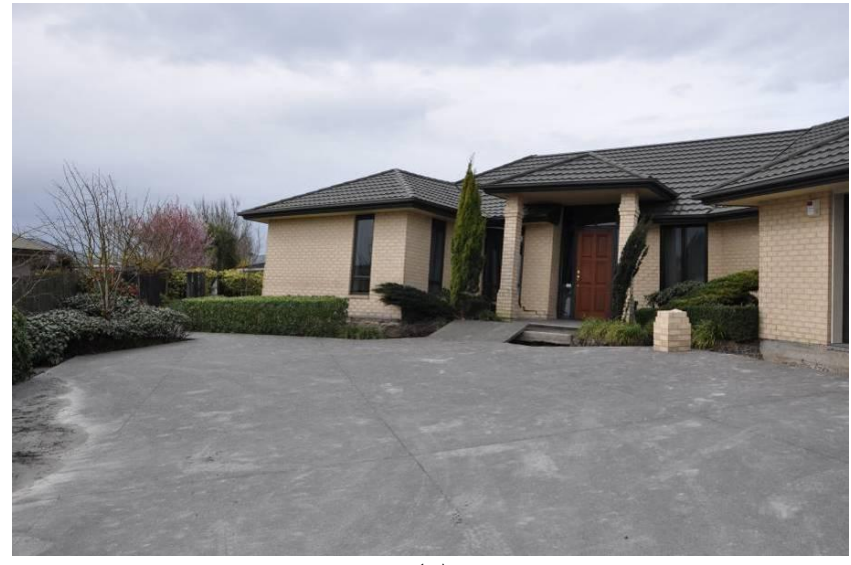

(a)

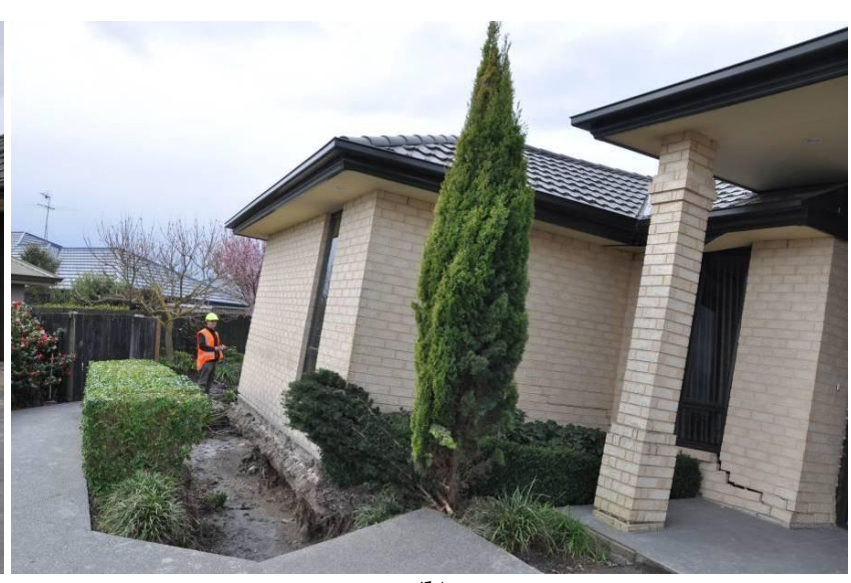

(b)

Figure 5.21: Damage to a residence at Courtenay Drive in the South Kaiapoi residential community (front of home articulating excessive tilt and separation of foundation from surrounding hardscape).

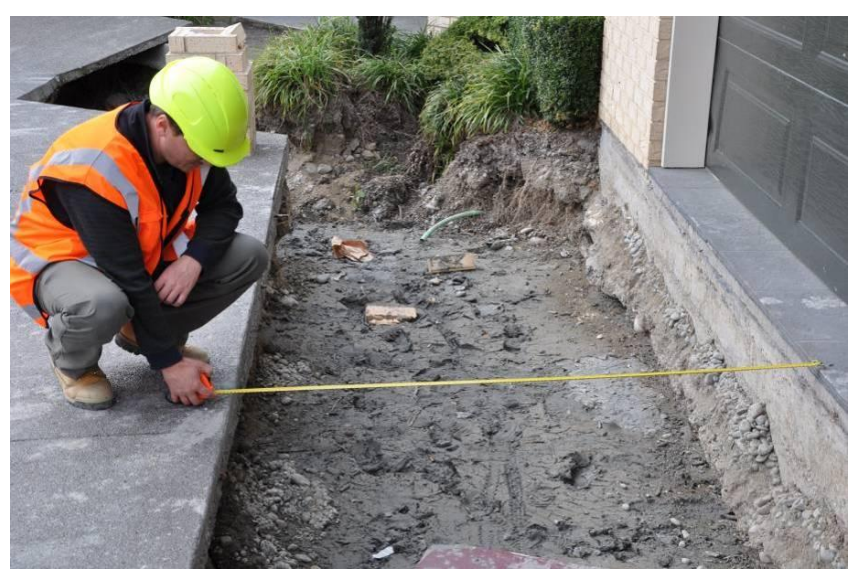

(a)

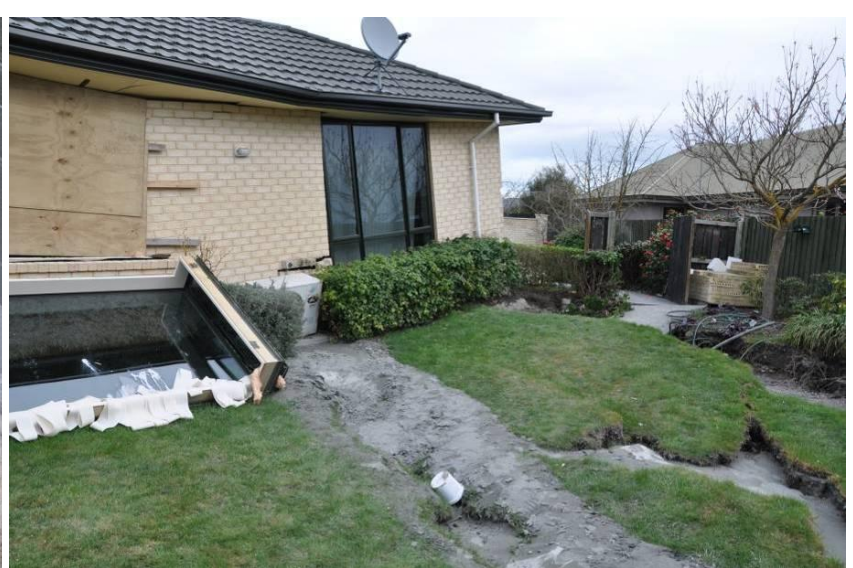

(b)

Figure 5.22: Damage to a residence at Courtenay Drive in the South Kaiapoi residential community (a) front of home (1.5 $\mathrm{m}$ separation between garage and approach slab) and (b) back of home.

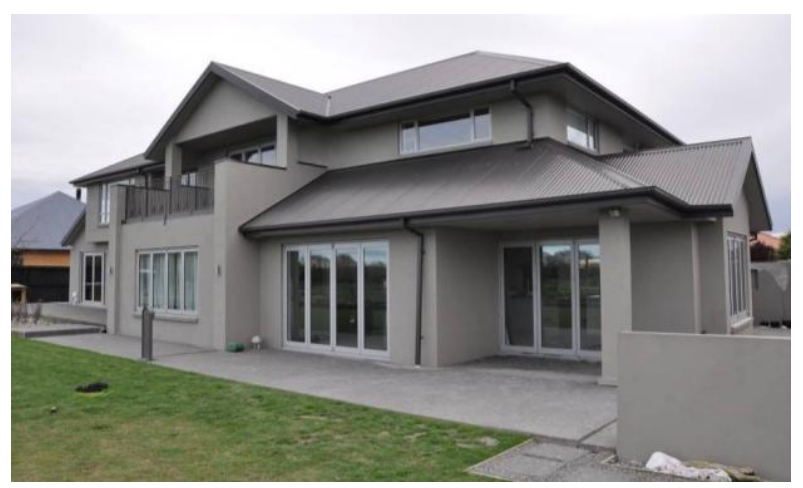

Figure 5.23: Damage to a residence along Courtenay Drive in the South Kaiapoi residential community. Rear of home facing Paddocks field articulates relatively no damage. 


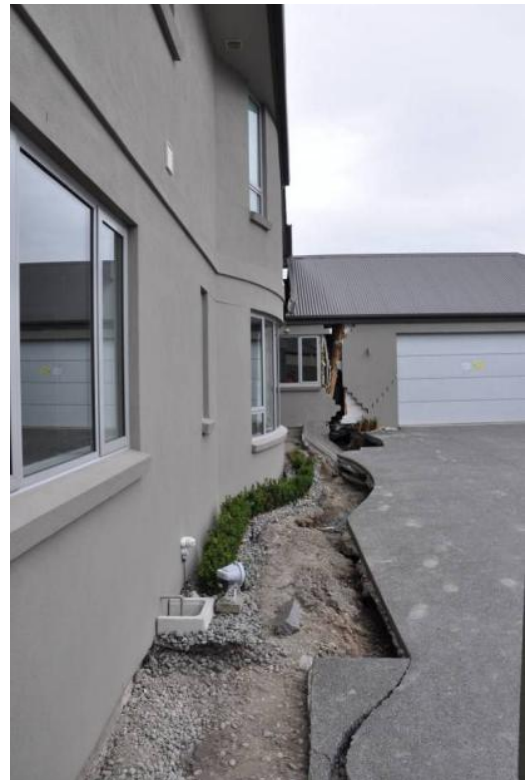

(a)

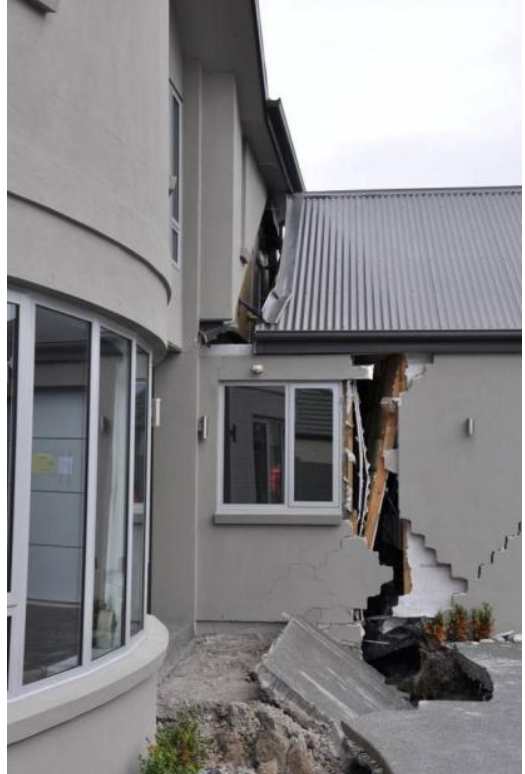

(b)

Figure 5.24: Damage to a residence along Courtenay Drive in the South Kaiapoi residential community. Front entry articulates extensive damage as large ground spreading subtends into the superstructure.

\subsection{Dallington Area}

\subsubsection{Dallington Residential}

The Dallington residential community was heavily impacted by liquefaction, and where the Avon River meanders through the community, those structures nearest the river were impacted by lateral spreading (see Chapter 4 for details regarding liquefaction extent in this area). The structural impact on residences was largely localized to settlement and rigid body movement in these regions, with the exception of St. Paul's church and surrounding school (refer to subsequent section) and residences nearest to the Avon River which suffered loss of ground support due to lateral spreading.
Residential construction in this area appeared to be range in vintage, with the oldest houses constructed in the early 1900 s and predominant construction dates from 1960s for the rest. Most structures were brick or light wood framing with stucco finish and 1-storey. A few structures had been remodelled to incorporate a second storey. The foundation system of these residential structures appeared to be stem walls with floating slabs or in some cases elevated wood flooring was apparent as viewed from access crawlspaces. Residents interviewed in this neighbourhood indicated that, following the mainshock, the sand ejecta with thicknesses on the order of 600-700 mm encompassed in many cases their entire property.

Two common types of damage to residential structures within this community are shown in Figures 5.25 and 5.26. Both of these structures are located near the Avon River. The residence shown in Figure 5.25a directly fronts the Avon River and experienced approximately 3 degrees of rigid body

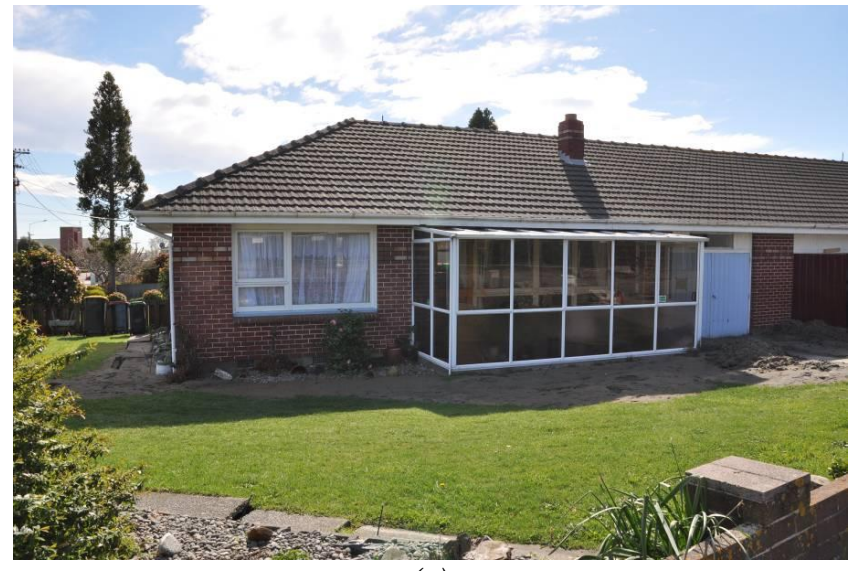

(a)

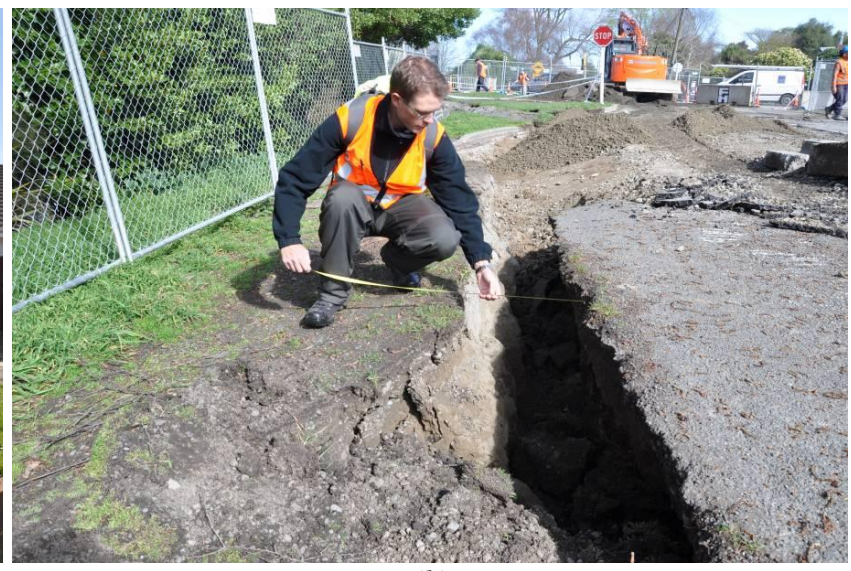

(b)

Figure 5.25: (a) Rigid body rotation of a residence in Dallington (Locksley Avenue) due to liquefaction and (b) lateral spread features directly fronting the home. Surveys of ground features at this location are associated with T7 (refer to Figure 5.27). 
tilt directly south towards the river. Structurally the home was in good condition, though inspection of the interior articulated extensive floor and nonstructural damage. Lateral spreading extension features were observed at the front of the residence at the river and continued north behind this residence (Figure 5.25b). Transects taken by the NZ-GEER team on 14 September 2010 at this location indicate $85 \mathrm{~cm}$ of lateral extension fronted the residence, with vertical offsets in extensions as large as $190 \mathrm{~mm}$ and cracks extending as great as $1.05 \mathrm{~m}$ ( $\mathrm{T} 7$ in Figure 5.27). Figure 5.26 shows a house in Locksley Avenue, which illustrates a loss of ground support subtended along the structure length. At this location lateral spreading towards the Avon River (behind the position from which the photo was taken) is evident in the driveway. Differential settlement along the length of the house manifests itself as shear cracking and separation of the mortar-brick within the brick veneer wall. This mode of deformation is similar, but less intense, to that imposed on the slab-on-ground foundations of the houses illustrated in Figures 5.20-5.24.

Detailed mapping of lateral spreading features extending from the Avon River into the Dallington residential community were performed by a NZ-GEER team on 14 September 2010. A map of these transect locations is shown in Figure 5.27. Future reports will include elevations and additional details of these ground features.

\subsubsection{St. Paul's Church and School}

A historically significant feature in the neighbourhood of Dallington is the St. Paul's church and surrounding school (Figure 5.28; $43.5196^{\circ} \mathrm{S}, 172.6725^{\circ} \mathrm{E}$ ). St. Paul's church was severely damaged due to surrounding ground movement, which was precipitated by extensive liquefaction within the general area shown in Figure 5.28. Most significantly the structure suffered through building separation due to ground extension and vertical offset subtending north-south approximately one-third of the length along the west end (orange separation location denoted in Figure 5.29).

This resulted in structural separation of the building into two distinct structures. The West end of the building rotated 2 degrees south and 4 degrees west (Figures 5.30-5.33), resulting in $460 \mathrm{~mm}$ of settlement of the south-west corner (estimated with reference to prior ground elevation). No significant lateral translation of the building was measured at its perimeter rather structural movement was confined to rotation and settlement as described in Figure 5.29. This relatively heavy single storey structure was constructed of running bond brick perimeter walls, with a timber (truss) roof. Wall heights were approximately $8 \mathrm{~m}$ at the perimeter of the sloping roof and $5.5 \mathrm{~m}$ at flat portions. An approximately $12 \mathrm{~m}$ tall tower is articulated at the southeast corner of the structure (Figure 5.33b). The ridgeline extends across the longitudinal axis (running approximately east-west) along the building.

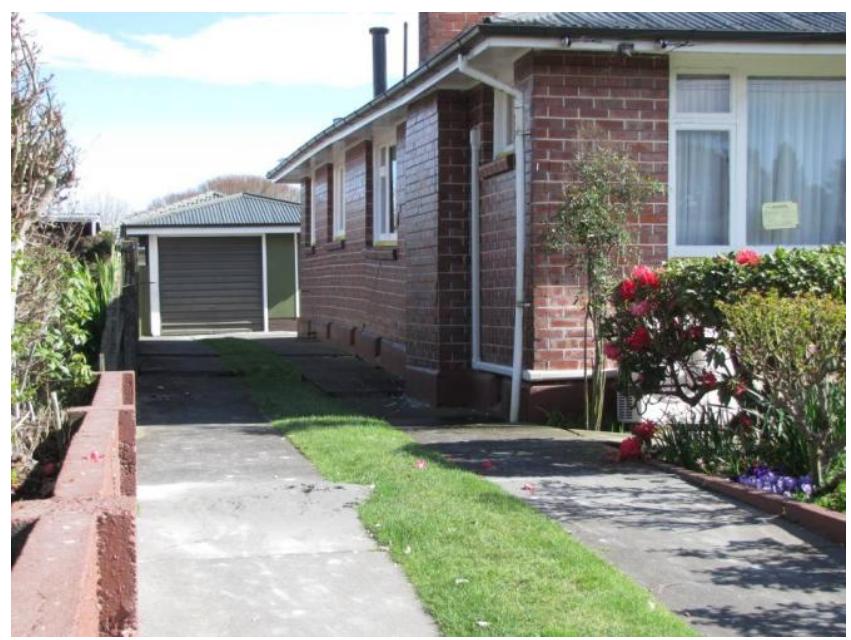

Figure 5.26: Residence affected by lateral spreading along the driveway which has induced differential settlement between the front and rear of the house. (Note that this is not a slab-on-ground house, rather an older style of construction with a concrete perimeter beam and the timber floor being supported on shallow foundations; Locksley Ave).

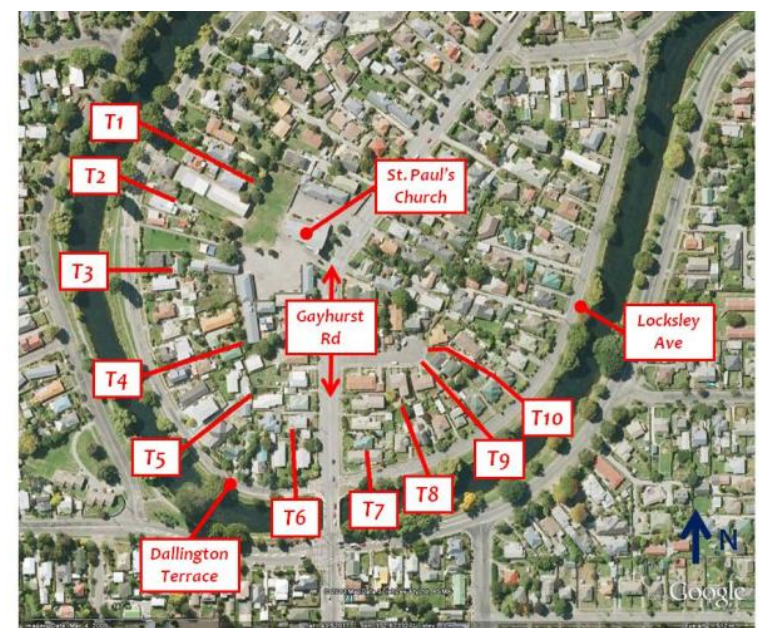

Figure 5.27: Ground feature mapping locations taken by the NZ-GEER team on 14 September 2010 (Annotations overlaid with GoogleEarth image). 
The north and south (long axis ends) of the building articulate approximately $25 \%$ glass windows. Similarly the East entry facing Gayhurst Road presents stained glass features surrounded by brick walls (Figure 5.33b). The foundation was not accessible at the time of the NZ-GEER team's visit.

Surrounding St. Paul's church is an Integrated State school affiliated with the church (buildings denoted B1-B8 in Figure 5.28). Building B1 (Figure 5.34) and B6 (Figure 5.36) are constructed of running bond brick perimeter walls with light metal roofs, whereas buildings B4, B5, and B7 incorporate light wood framing along their longitudinal axes and brick along their transverse axes (e.g. Figure 5.37). Building B2 is constructed of concrete masonry block units (Figure 5.35).
All structures within the school appeared to be supported on elevated stem wall footings with interior wood joists, with the exception of B2, which appeared to be at grade with a slab on ground. Buildings B1-B8 are all single storey with wall heights ranging from 7-8 $\mathrm{m}$. Stiff brick and CMU buildings within this school complex suffered shear cracking and in some cases significant separation of brick-mortar joints (e.g. Figures $5.35 \mathrm{~b}$ and 5.36b). Likewise mixed construction structures, such as building B7 suffered damage due to relative movement between contrasting materials (Figure 5.37b). Flexible wood buildings suffered little observable structural damage with the exception of hairline cracks in stucco aligned with ground movement features.

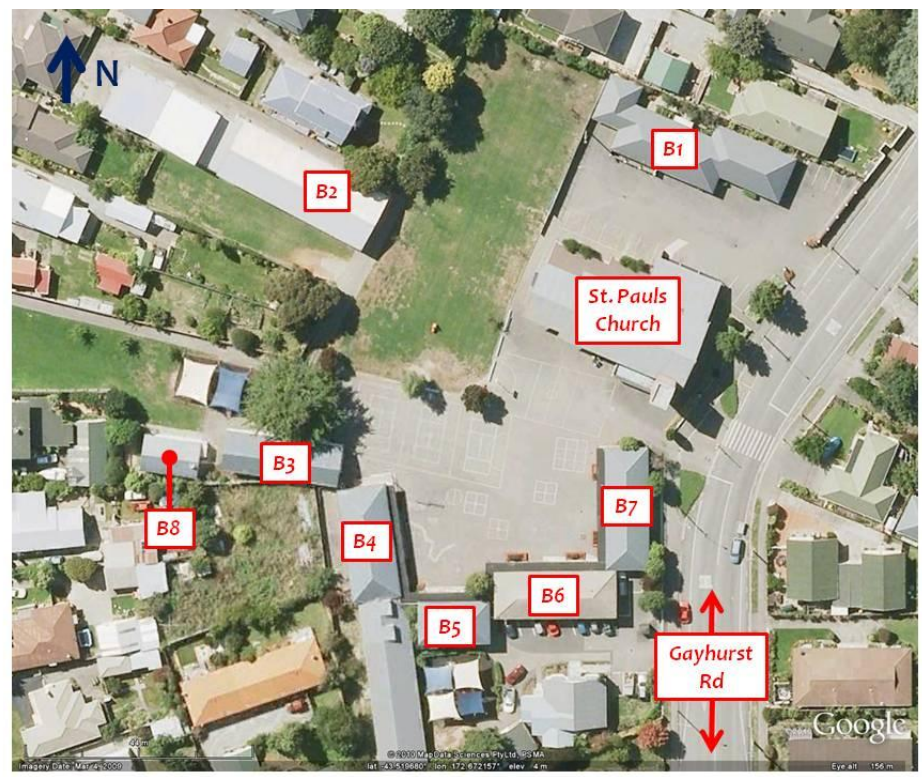

Figure 5.28: St. Paul's church and school in Dallington area $\left(43.5196^{\circ} S, 172.6725^{\circ} \mathrm{E}\right)$. Notation "B\#” is used for reference only to identify adjacent buildings (see discussion). Annotated GoogleEarth image.

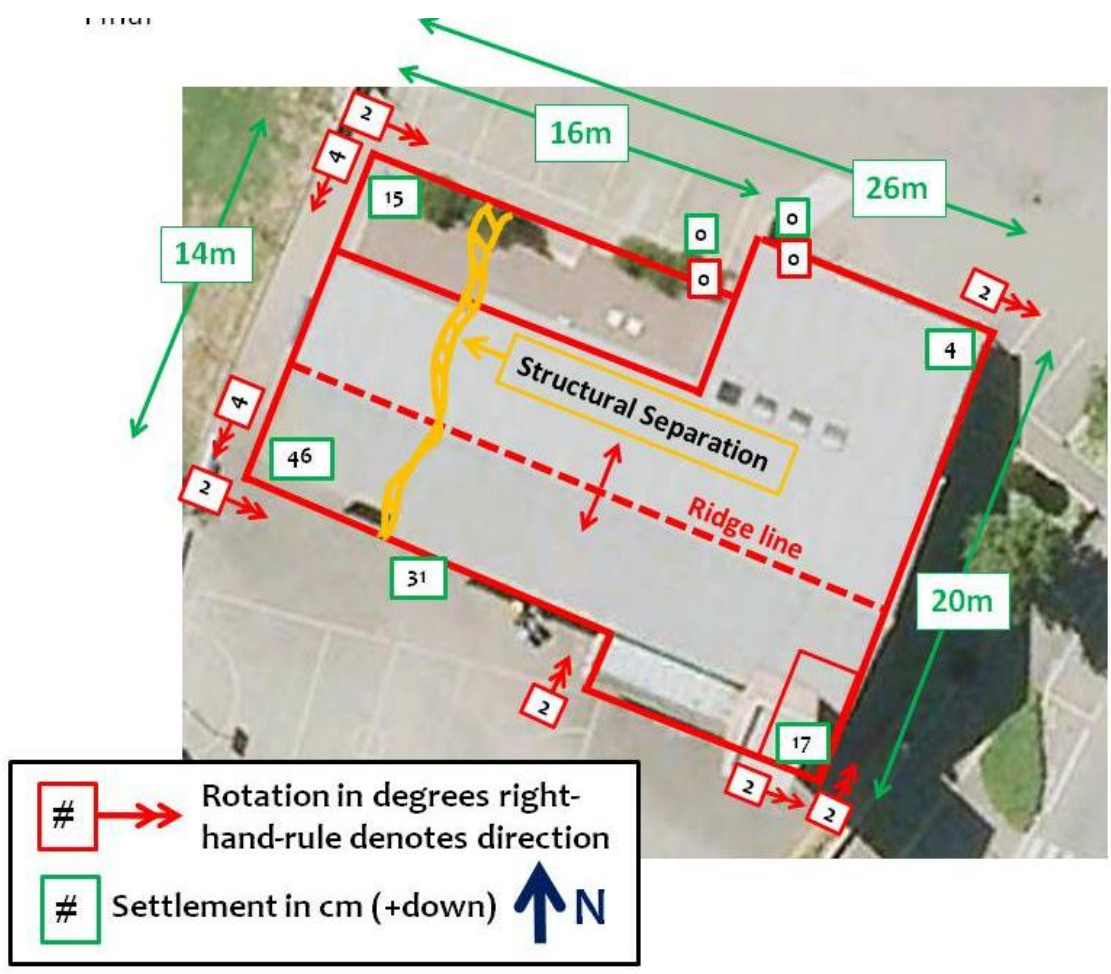

Figure 5.29: St. Paul's church damage map - survey conducted 12 September 2010; Global dimensions approximate (extracted from Google Earth image), deformation obtained directly in the field. 


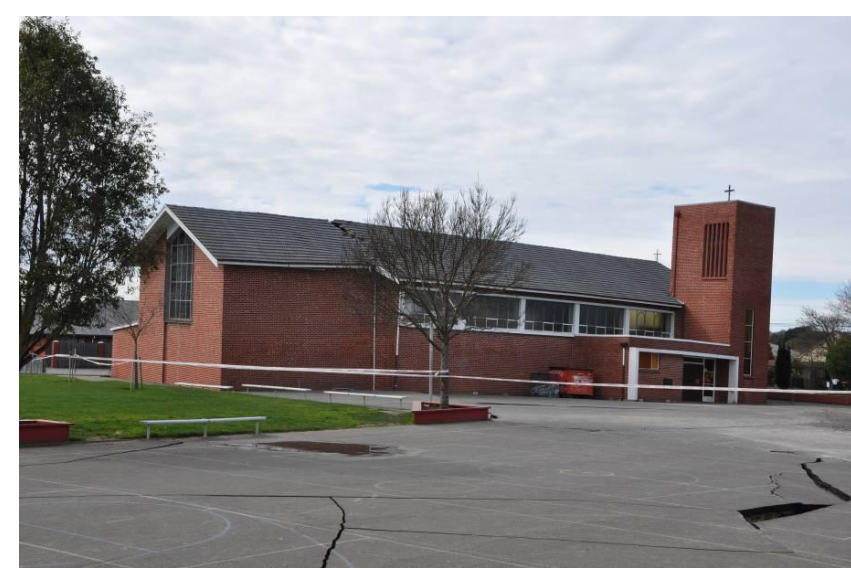

Figure 5.30: St. Paul's church in Dallington area - overall view of building looking north-east.

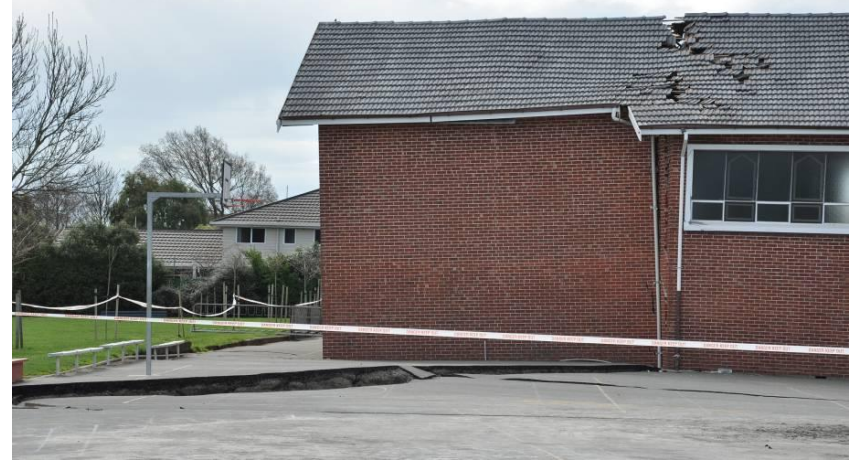

(a)

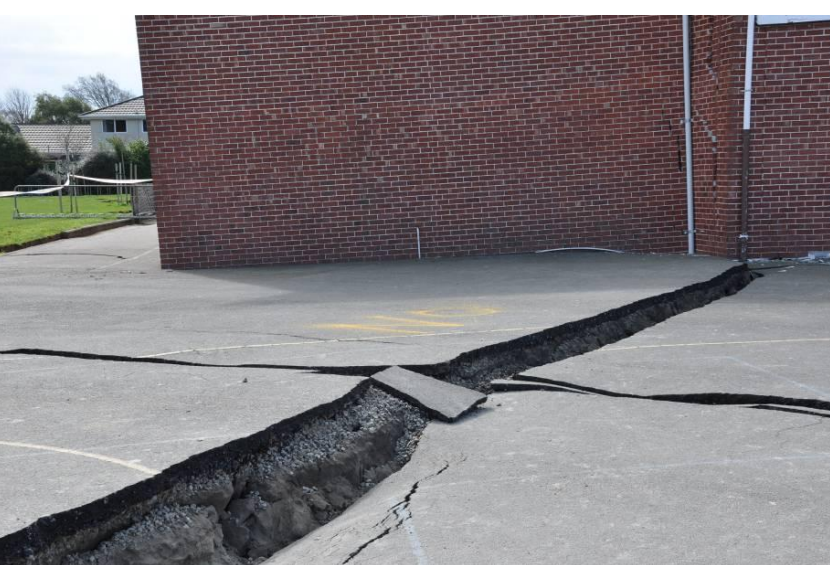

Figure 5.31: St. Paul's church in Dallington area - view looking north at ground failure, which continued through the building.

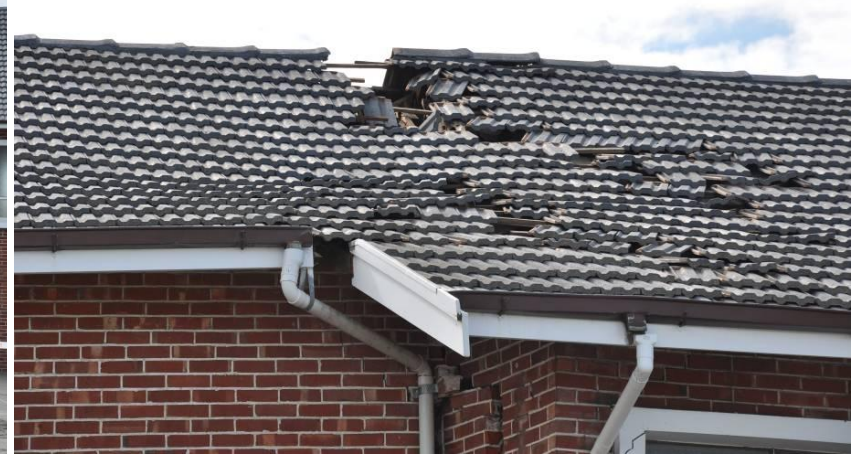

(b)

Figure 5.32: St. Paul's church in Dallington area - view looking north (a) far view of separated west end of building and (b) close-up view of structural separation.

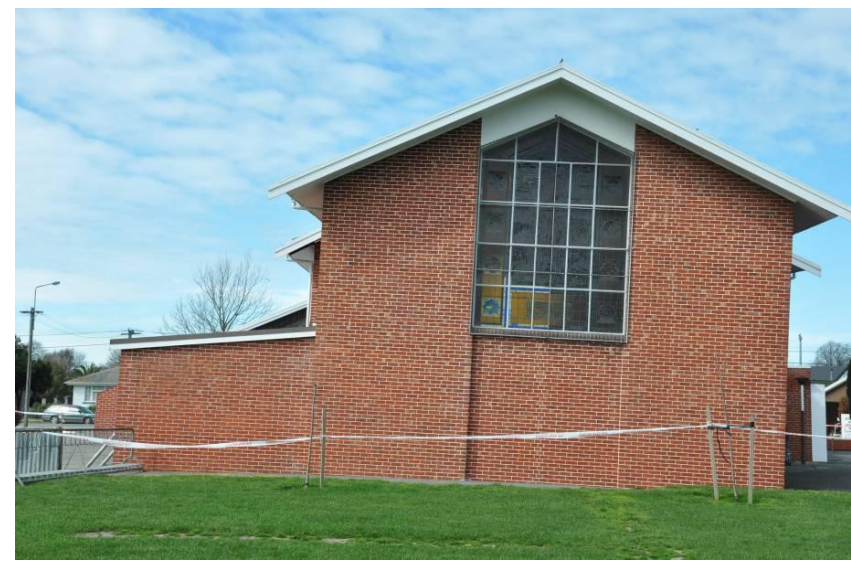

(a)

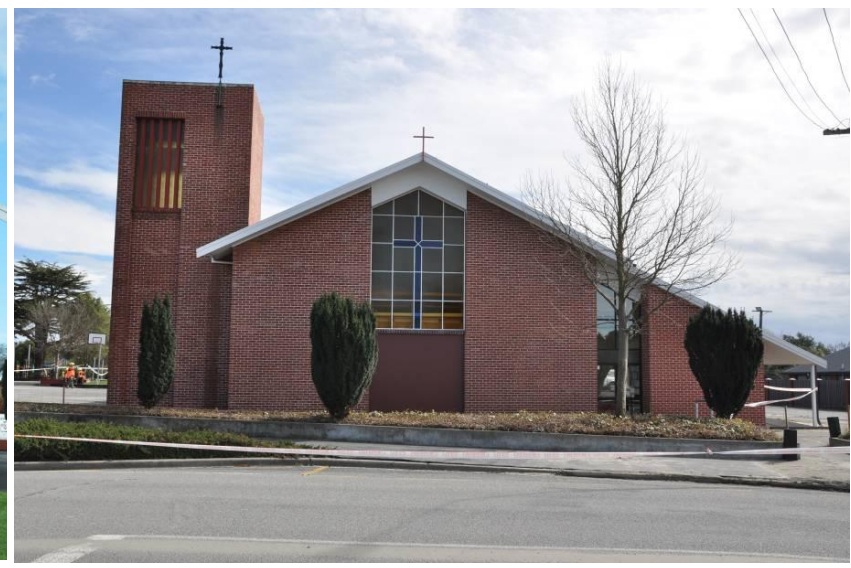

(b)

Figure 5.33: St. Paul's church in Dallington area: (a) view looking east at the west end and (b) view looking west at the east end. 


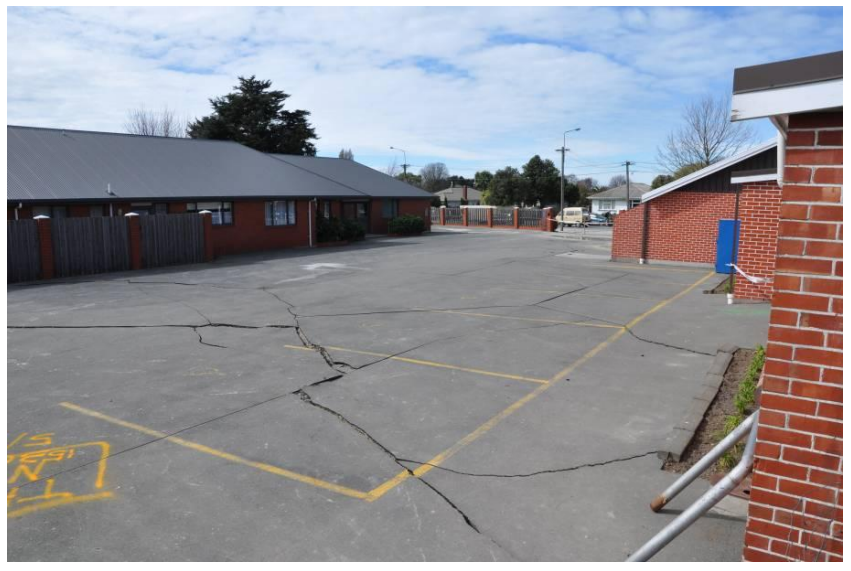

Figure 5.34: St. Paul's church and surrounding school-Building B1 (on left) and St. Paul's church (on right).

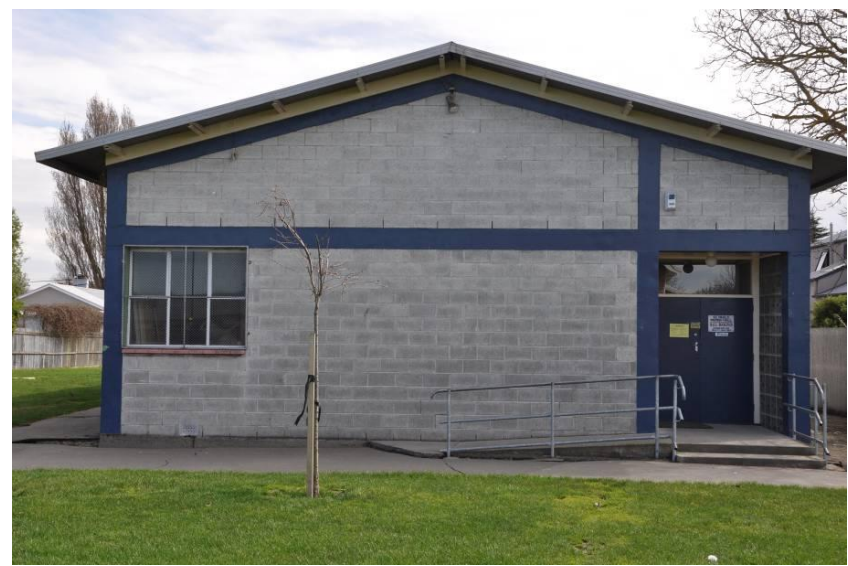

(a)

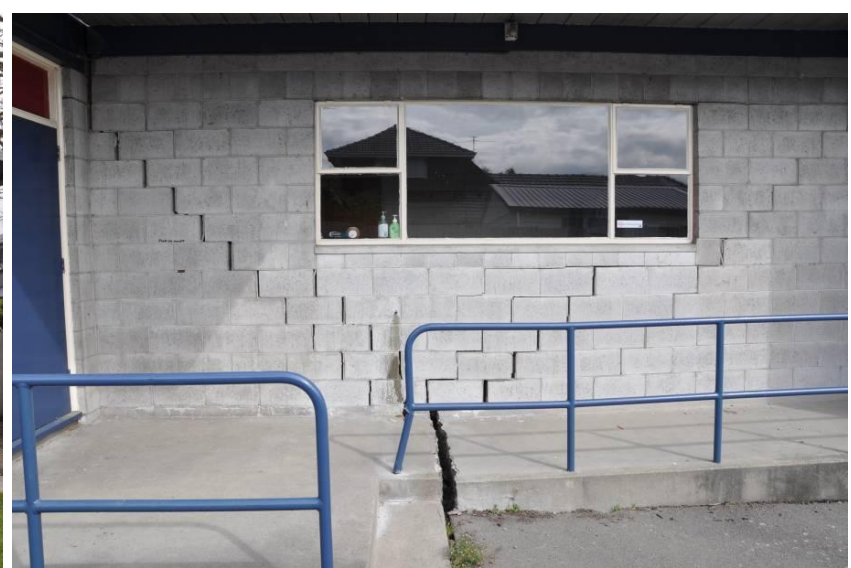

(b)

Figure 5.35: St. Paul's church and surrounding school-Building B2: (a) view looking west and (b) view from north side of building, looking south.

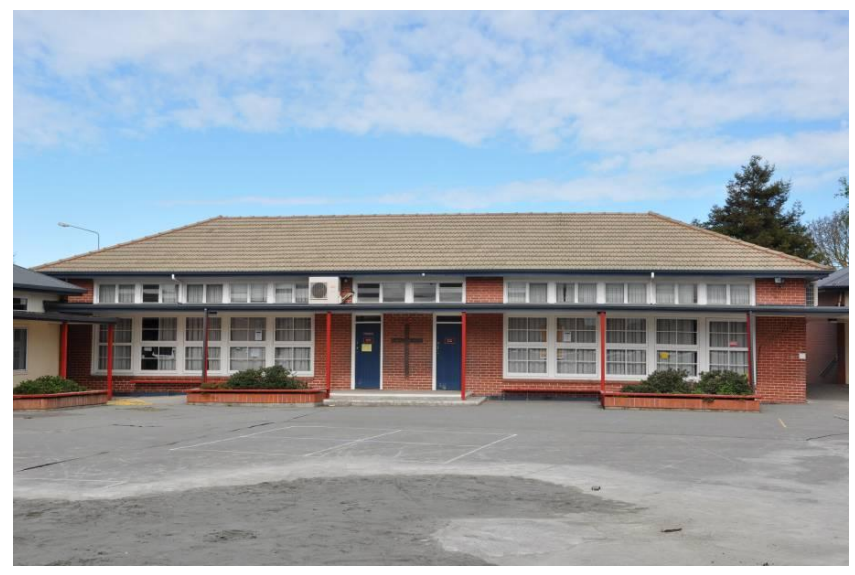

(a)

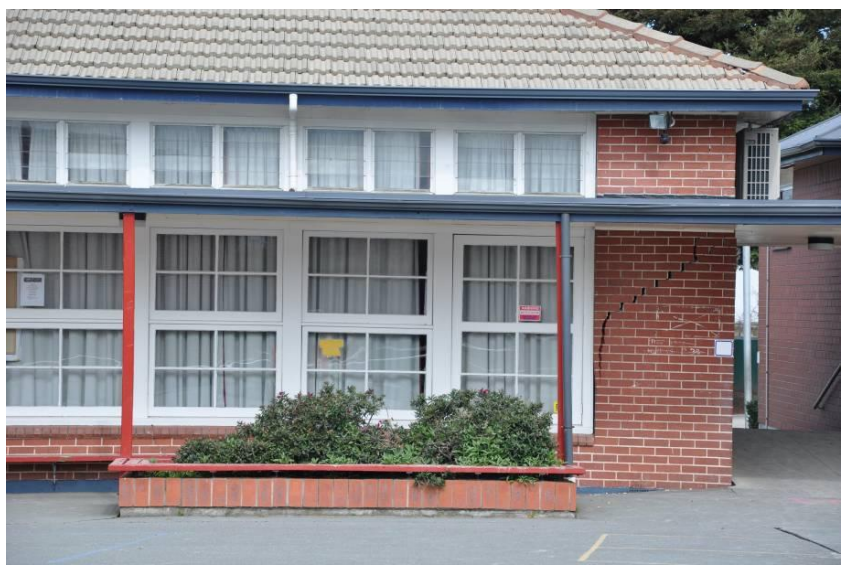

(b)

Figure 5.36: St. Paul's church and surrounding school - Building B6 view looking south: (a) overall view of building and (b) west end of building. 


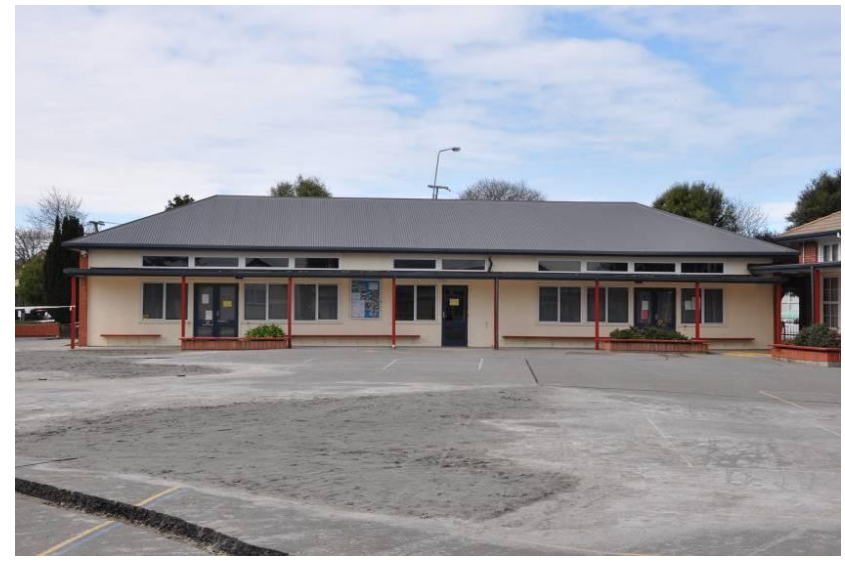

(a)

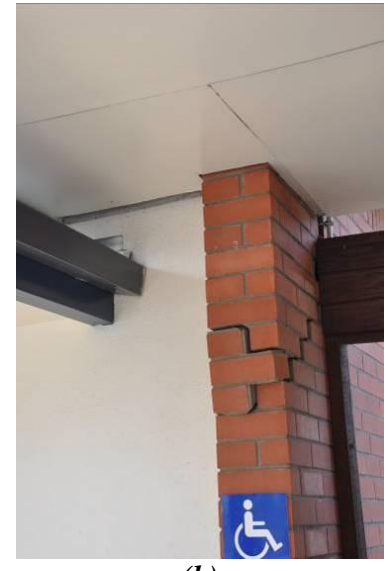

(b)

Figure 5.37: St. Paul's church and surrounding school - Building B7: (a) view looking east and (b) view of south-west corner of building articulating column damage at wood-brick interface.

\subsection{Bexley Residential Area}

In the residential area of Bexley, homes were significantly affected by lateral spreading (e.g. Figures 5.38-5.39). The lateral spreading was apparent from walking around the path along the southern boundary of the subdivision next to the wetland. Fissures of $300 \mathrm{~mm}$ or greater in width traversed the ground of several properties. A floor slab fissure (estimated width 50 to $75 \mathrm{~mm}$, visible because the carpet had been lifted) extended across the full width of one house. Settlement had occurred but with relatively little tilting. Given that the fissure went through the concrete floor slab, there appeared to be relatively little damage to the walls.

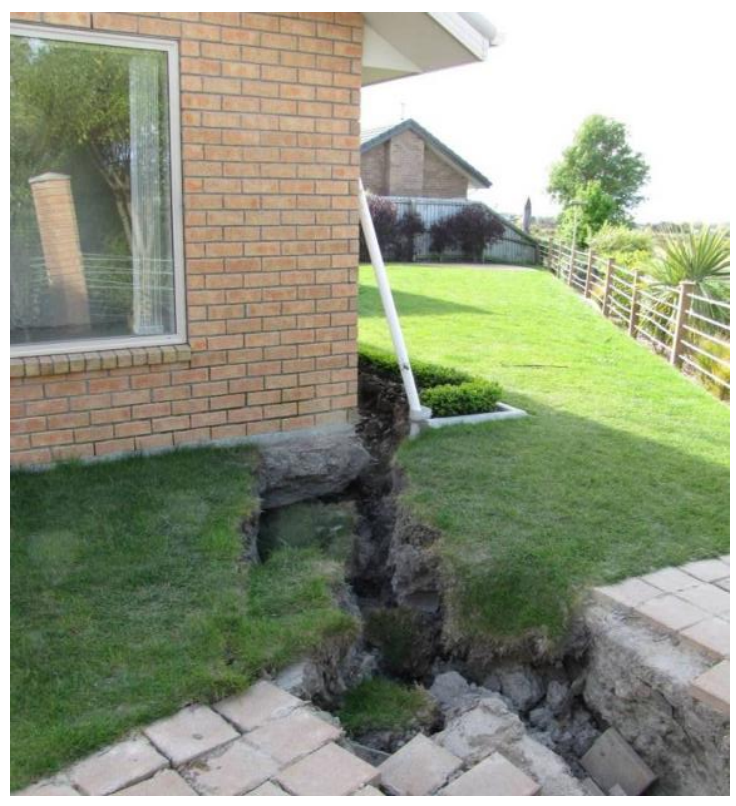

Figure 5.38: Lateral spreading compromising ground support beneath the concrete slab-on-grade house foundation. (Kokopu Street).
Foundation details taken during a visit to one home in Bexley are shown in Figure 5.40. The system set-out in Figure 5.40 is a perimeter beam with two D16 bars, D10 starter bars $600 \mathrm{~mm}$ long at $600 \mathrm{~mm}$ centres around the edges. The cavity inside the perimeter beam is filled with coarse gravel, covered with dampcourse, and then topped with a $100 \mathrm{~mm}$ thick concrete slab, which, apart from the starter bars, is mostly unreinforced. The drawing in Figure 5.40 specifies mesh reinforcing in areas that are to be tiled or covered in vinyl. Nonetheless, reinforcing was not observed to cross any fissure as noted in the drawing.

For contrast, an open foundation construction in the Pines Beach area (near Kaiapoi) was observed on 12 September 2010. The perimeter footing had been completed and the gravel fill was in place, the concrete slab was yet to come.

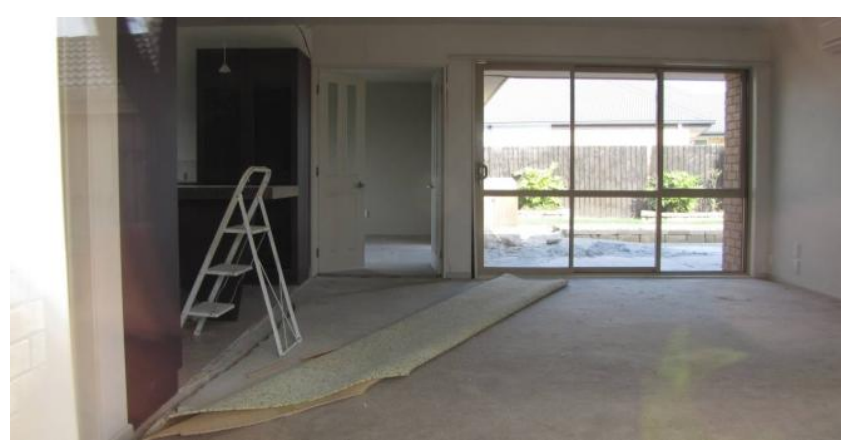

Figure 5.39: Fissure in concrete floor slab (to the left hand side passing beneath the ladder). (Same house as in Figure 5.38.) (Kokopu Street).

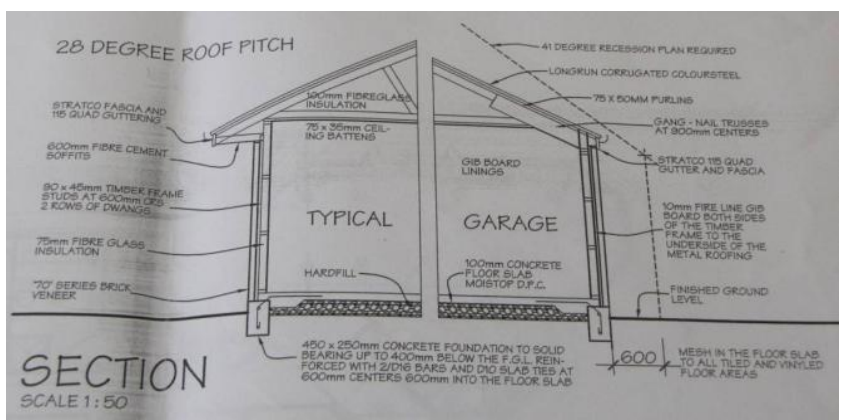

Figure 5.40: Concrete slab-on-ground details for the Bexley houses. 
Assuming the top of the perimeter footing was close to level before the event, it was apparent that the footing was not capable of withstanding the ground deformation during the earthquake as the footing was no longer level (Figure 5.41). Two D16 reinforcing bars were observed in this footing where cracking had occurred.

Concrete slab-on-grade foundations have been used in New Zealand for single and two storey timber framed houses for more than 40 years. The current code covering this type of construction is NZS3604:1999 "Timber framed buildings", which has evolved from previous versions dated 1984 and 1990. The slab-on-grade details shown in Figure 5.40 appear to be in compliance with the NZS3604 which allows, for single storey dwellings, unreinforced floor slabs in dry areas but requires mesh in wet areas. The application of NZS3604 is based on the concept of "good ground". If the site satisfies this condition then no additional engineering design is required as the developer is able to follow the details set out in NZS3604. Site conditions that exclude the application of NZS3604 are specified as peat, soft clay and expansive clay, all of which are identifiable using rudimentary site investigation techniques.

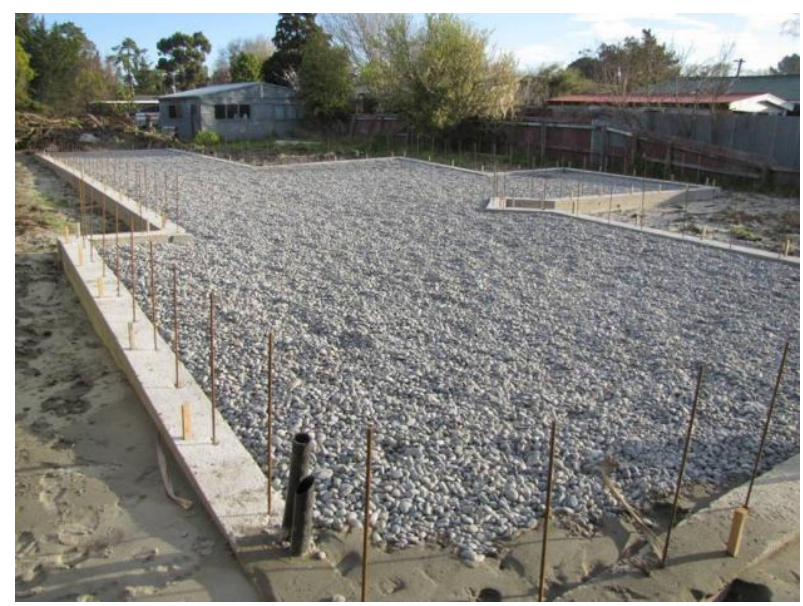

Figure 5.41: Site at Pines Beach which appears to be using the same slab-on-grade system as at Bexley (Chichester Street)
Liquefiable soil is not mentioned. Preliminary site investigations, conducted following this earthquake, indicate that the liquefiable layer is often deeper than $1 \mathrm{~m}$ and not infrequently deeper than $2 \mathrm{~m}$ (Figure 5.42). This means that the possibility of liquefaction is not as easily identifiable as the above three "good ground" exclusions.

\subsection{Spencerville Residential Area}

The residential communities of Spencerville and Brooklands were significantly impacted by liquefaction and lateral spreading induced ground damage. Lateral spreading was confined to regions along the Styx River (Figure 5.43), whereas liquefaction was pervasive throughout these two small communities, but particularly along the regions nearest the Brooklands Lagoon. Particularly significant structural damage due to laterally spreading ground was observed along Riverside Lane paralleling the Styx River (inset on right of Figure 5.43). Here five large and newly constructed (all within the last 10 years) homes were severely damaged due to laterally spreading ground (Figures 5.44-5.47). These houses were relatively large structures $\left(200-300 \mathrm{~m}^{2}\right)$, compared to other developments in or surrounding Christchurch, and each appeared to be a custom design. All appeared to be resting on slab foundations with either light wood framing or brick/CMU walls. Unlike other areas affected by the earthquake, little ejected sand was observed, however strain relief manifested in the form of large lateral spreading ground fissures up to 400$500 \mathrm{~mm}$ in width in the worst places. The houses suffered only minimal settlement, however the laterally spreading ground continued through the homes, tearing ground slabs apart and propagating structural damage upwards towards the roofline (the roofline damage pattern here was not unlike that seen at St Paul's church in Dallington). From perimeter and interior views of the foundations of these homes, no reinforcing steel appeared to be present in the main slab. Residential structures in this area with the most severe damage were those with their longitudinal axis in the direction of the lateral spreading. Lateral spread features were long and extended through many properties (e.g. Figure 5.48). One home oriented with its long axis perpendicular to the direction of lateral spread had some damage at the connection between the garage and the house proper, but, unlike the others, was still occupied.
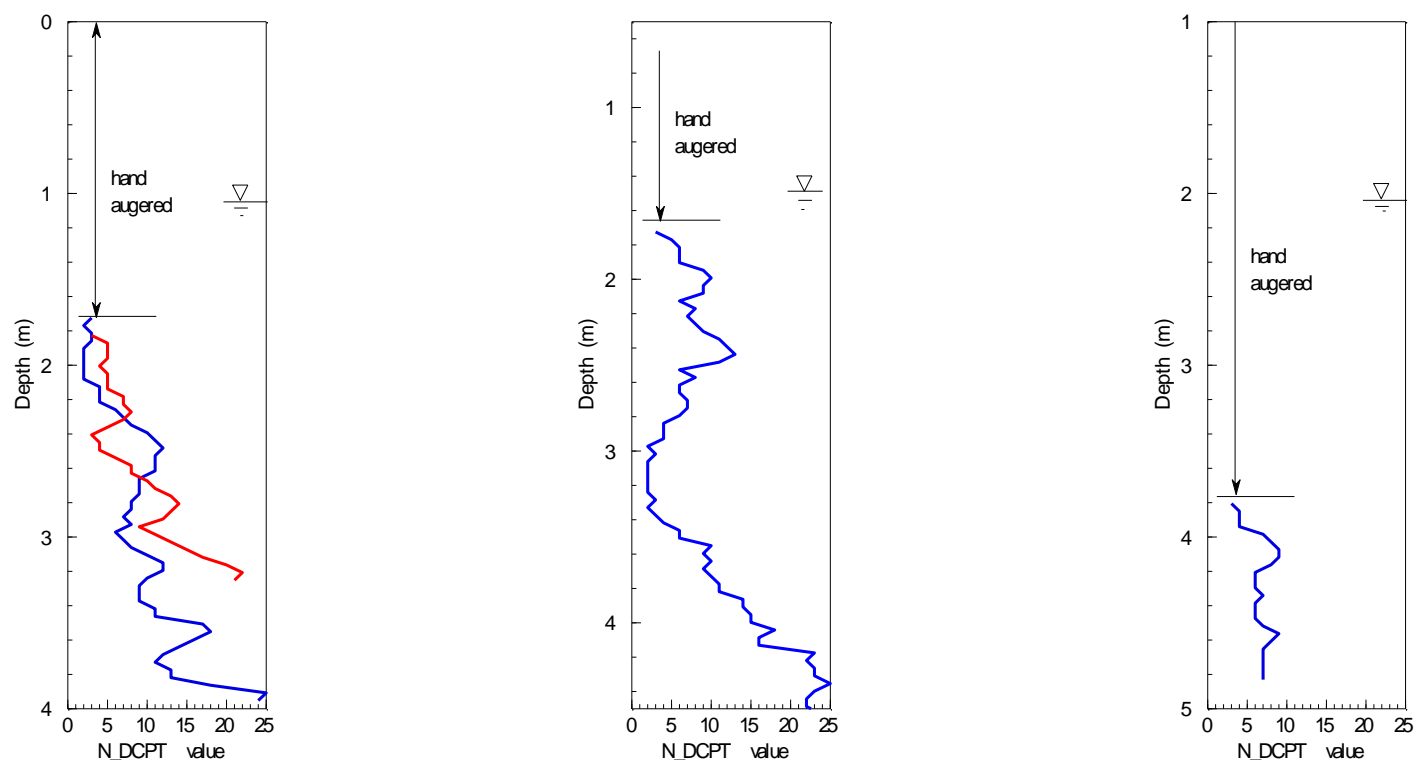

Figure 5.42: $\quad$ Results of the DCPT for the liquefiable layer for Spencerville (left: $43.43075^{\circ} \mathrm{S}, 172.693000^{\circ} \mathrm{E} ; 43.431583^{\circ} \mathrm{S}$, $172.693233^{\circ} \mathrm{E}$ ), Bexley (middle: $43.518370^{\circ} \mathrm{S}, 172.722050^{\circ} \mathrm{E}$ ) and Courtenay Drive (right: $43.390010^{\circ} \mathrm{S}$, $\left.172.662640^{\circ} \mathrm{E}\right)$. 


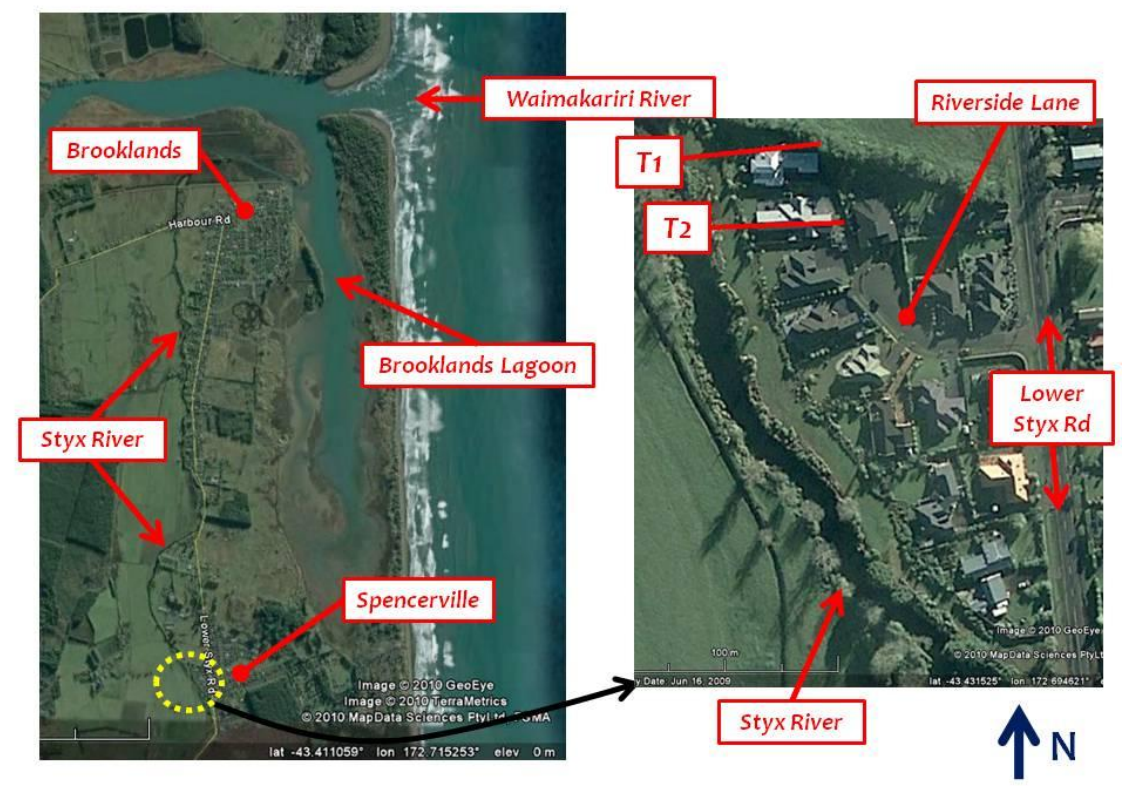

Figure 5.43: Spencerville and Brooklands communities (inset on right identifies surveys conducted by NZ-GEER team on 14 September 2010 along Riverside Lane); Annotated Google Earth image.

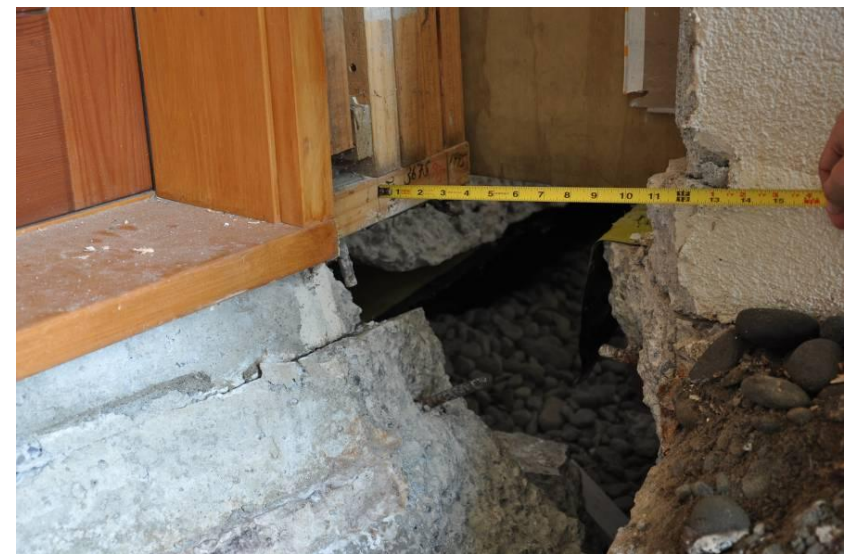

(a)

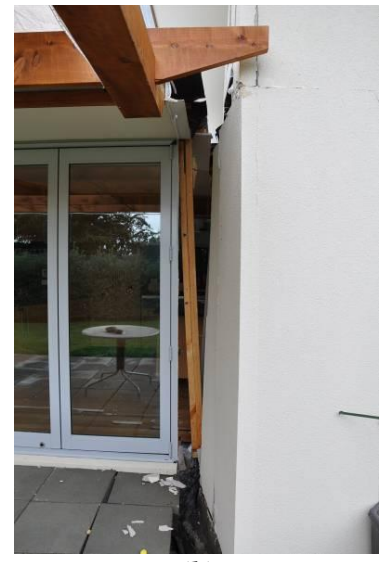

(b)

Figure 5.44: $\quad$ Ruptured floor slab near the front entrance of Riverside Lane. Clearly visible is the gravel infill shown in Figure 5.41 (note that there appears to be no ejected sand present). (a) ground fissure separating front entry of home and (b) same ground feature propagated through home and departing on opposing side.

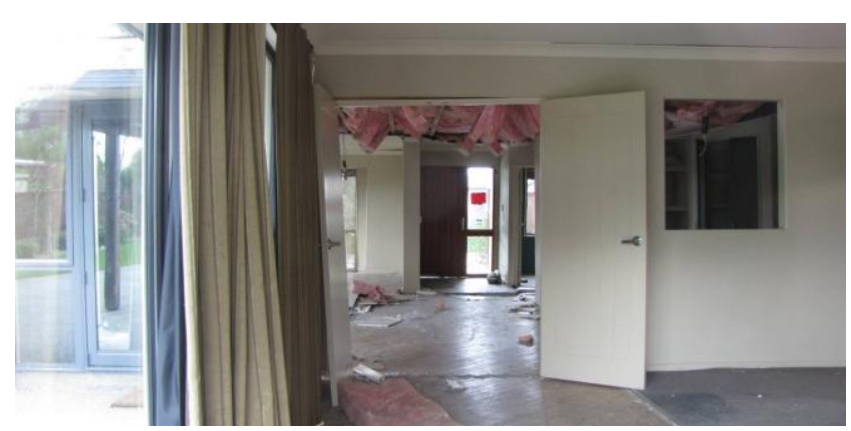

Figure 5.45: Interior view of residence at Riverside Lane. Note the two floor breaks visible in the picture

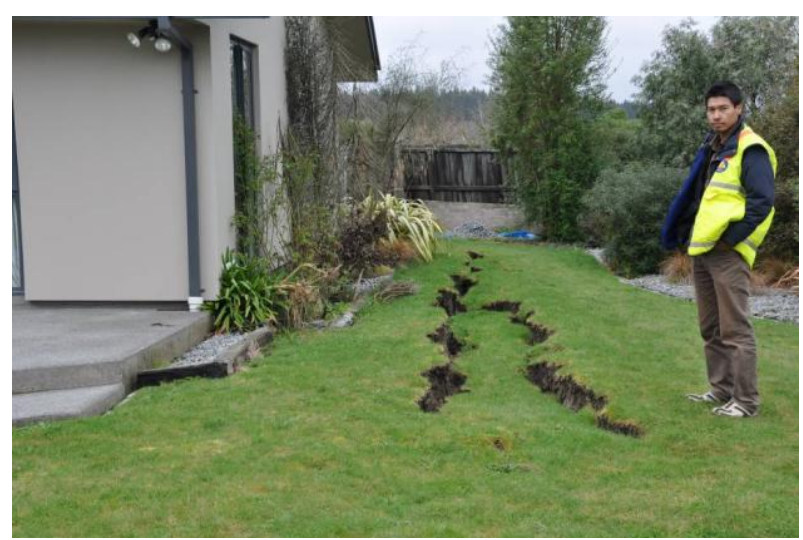

Figure 5.46: Lateral spread adjacent to residence at Riverside Lane. The location of this fissure is about 26 metres from the nearby Styx River. 


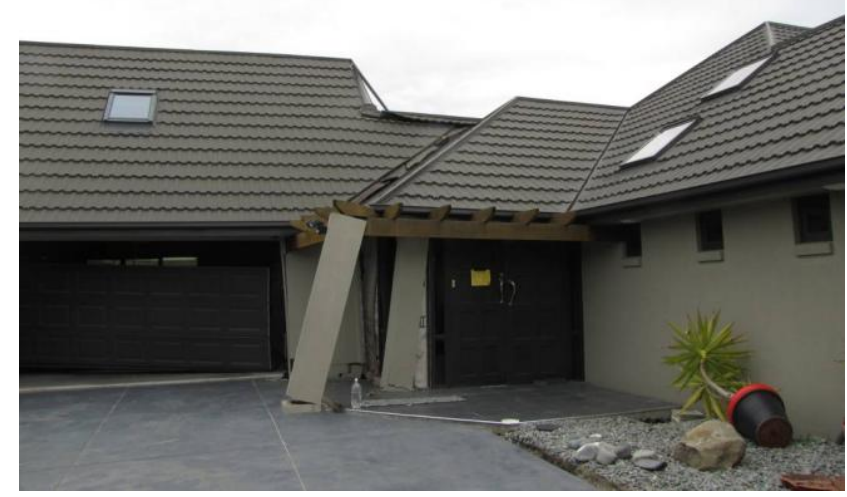

Figure 5.47: House with fissured floor slab with damage carried through to the roof line which is no longer weather proof. (Riverside Lane, Spencerville).

\subsection{Summary Remarks}

The above descriptions of structural damage as induced by ground failure lead to the conclusion that lateral spreading places much more severe demands on structures and particularly their foundations than that of liquefaction alone. Most importantly in this earthquake, residential structures were severely impacted by ground failure. Specifically, the following observations can be made:

- Large lateral spread fissures in many cases split entirely ground slabs and further propagated damage upward into structural walls and rooflines, in some cases creating severe structural separation.

- Geometric and reinforcing detailing for residential foundations appeared to consistently incorporate 100 $\mathrm{mm}$ thick unreinforced concrete slabs resting on perimeter footings reinforced with 2-D16 bars (Figure 5.44).

- In areas with significant liquefaction where little to no lateral spreading occurred, the main foundation response was settlement (uniform and/or tilting). In the worst instances the settlement was up to several hundred millimetres, however often with comparatively mild tilting.

In areas with little to no lateral spreading, slab-on-ground foundations appeared to cope with modest amounts of liquefaction.

\section{PERFORMANCE OF STOPBANKS (OR LEVEES) AND OXIDATION POND EMBANKMENTS}

\subsection{History of stopbank construction}

Shortly after their arrival in the Canterbury area in the midnineteenth century, the western settlers started constructing drainage systems and stopbanks (or levees) along rivers (Larned et al., 2008). Particularly, flooding of the Waimakariri River and tributaries posed a constant threat to the Christchurch and Kaiapoi areas. Early efforts to contain the rivers within their banks were piecemeal and only partially successful. To better coordinate the efforts, the Waimakariri River Trust was established in 1923 (Griffiths, 1979). In response to the 1926 floods (Figure 6.1), the Trust implemented a major river improvement scheme in 1930, known as the Hays No. 2 Scheme. Among other things, the scheme entailed an overall improvement of the stopbank

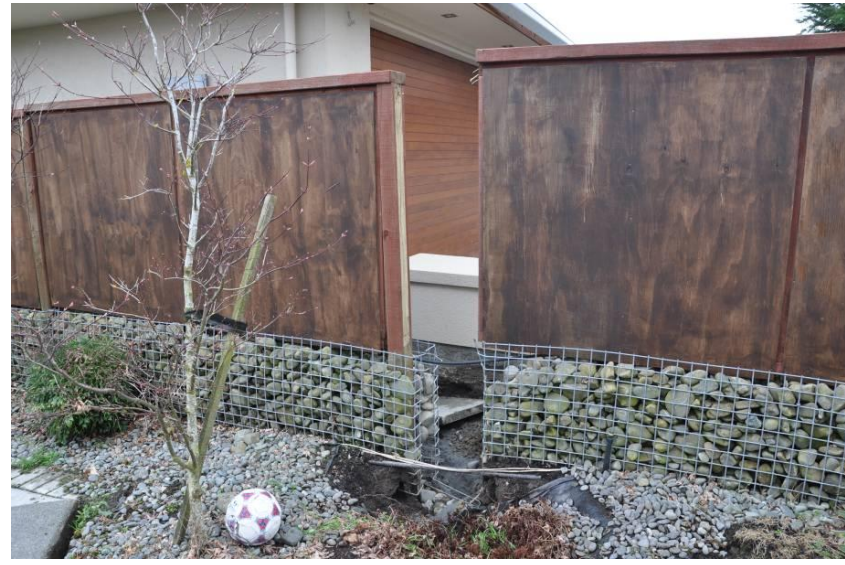

Figure 5.48: $\quad$ Separated fence line due to propagating ground fissure meandering between homes along Riverside Lane. system along the Waimakariri River. However, these improvements were unable to prevent the major floods in 1940, 1950, and 1957. These floods prompted a further river improvement scheme in 1960, which entailed benching existing stopbanks and construction of new stopbanks, which were compacted with vibrating rollers (Boyle, 2010). The stopbanks were designed to provide protection against the 100-year flood (Griffiths, 1979). Unfortunately, the geotechnical reconnaissance team has not yet been able to obtain construction drawings and/or specifications used in either the 1930 or 1960 improvement schemes for the stopbanks and are uncertain if such drawings/specifications exist.

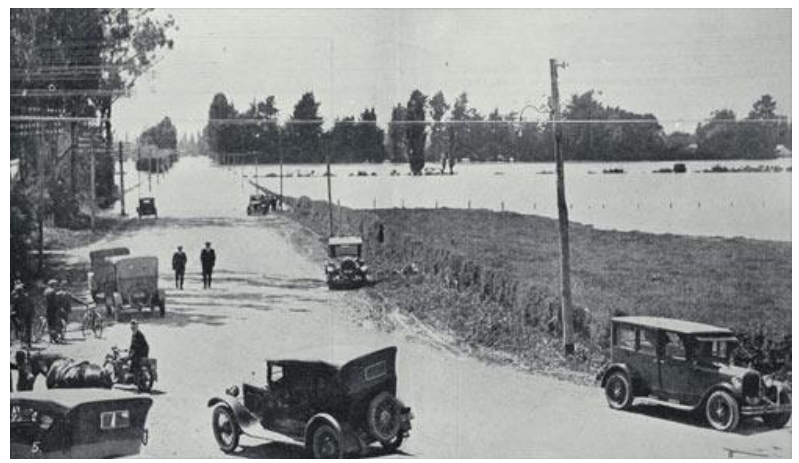

Figure 6.1: 1926 photograph of the Waimakariri River overflowing its banks in Christchurch. (Te Ara Encyclopedia of New Zealand, 2010).

\subsection{Seismic performance of stopbanks}

The geotechnical reconnaissance team performed damage surveys along stretches of the primary and secondary stopbanks for the Waimakariri River and along the primary stopbanks for the Kaiapoi River on the morning of the earthquake (4 September 2010) and then again a few days later (between 9-16 September 2010). The surveys were performed on foot, in an automobile, and from a helicopter. Figure 6.2 shows the stretches of the stopbanks that the NZGEER Team surveyed. The geotechnical reconnaissance team also corresponded with the Environment Canterbury (ECan) personnel (Ian Heslop and Tony Boyle) who are overseeing damage assessments and repairs of the stopbanks damaged during the earthquake. Below is a summary of the observed performance of the stopbanks along the Waimakariri and Kaiapoi Rivers. 


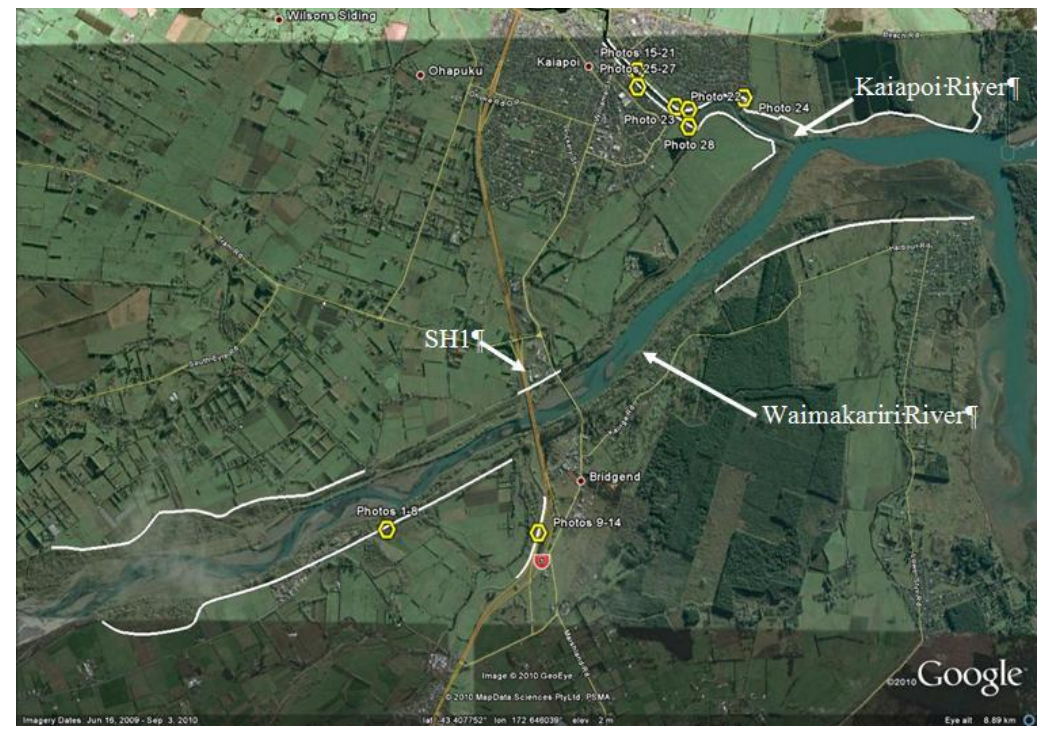

Figure 6.2: $\quad$ White lines denote the stretches of the stopbanks along the Waimakariri and Kaiapoi Rivers that the geotechnical reconnaissance team performed damage surveys. Also denoted in the figure is State Highway 1 (SH1).

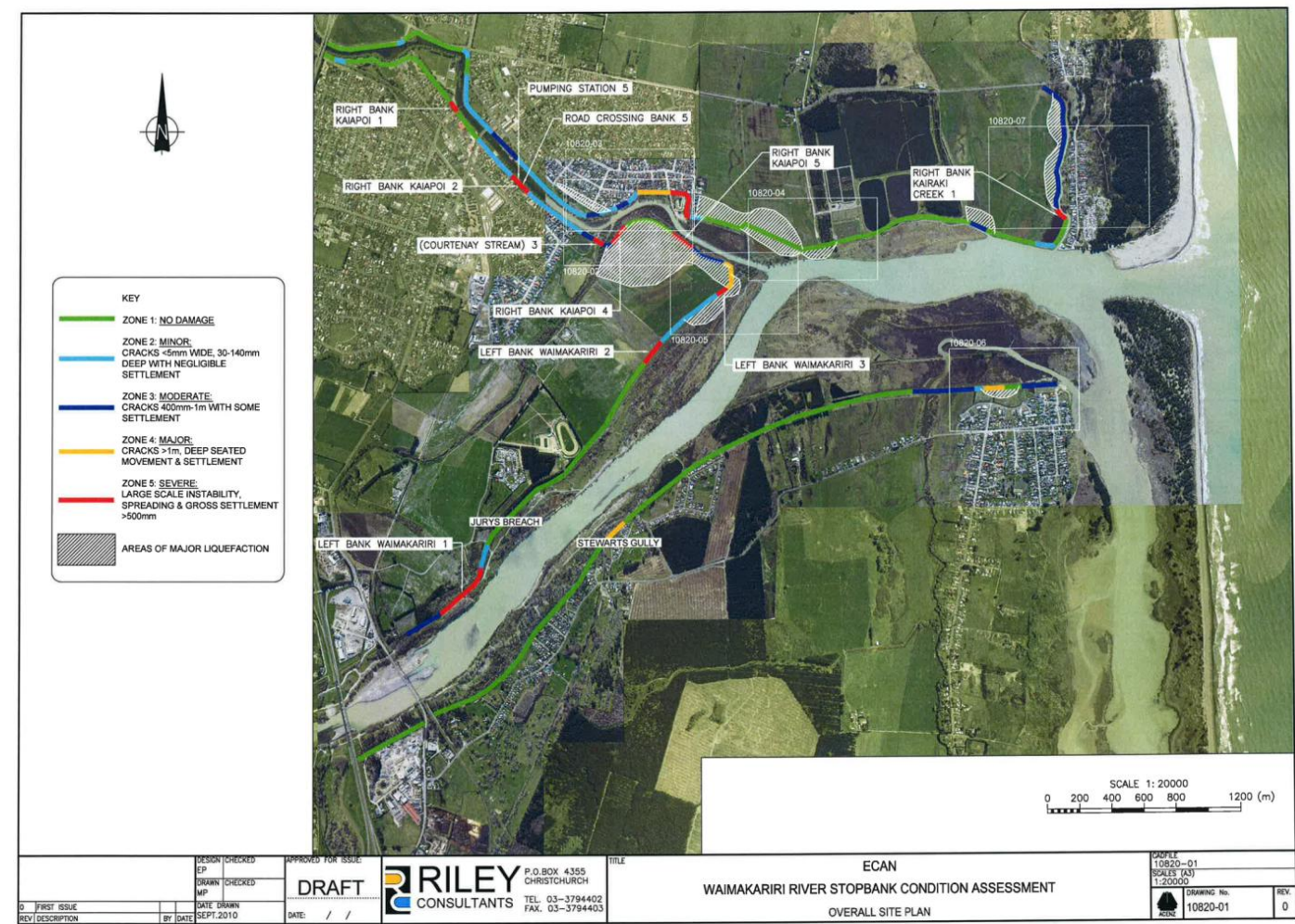

Figure 6.3: $\quad$ Post-earthquake damage survey of stopbanks performed by Riley Consultants for Environment Canterbury along the Waimakariri River, downstream of SH1, and Kaiapoi River. (Riley Consultants, 2010; courtesy of Ian Heslop and Tony Boyle, ECan).

\subsubsection{Waimakariri River stopbanks}

The Waimakariri River is the largest of the rivers in northern Canterbury and flows from the Southern Alps to the Pacific Ocean. The mean annual flow of the river is $120 \mathrm{~m}^{3} / \mathrm{sec}$. However, in 1957 the largest flood on record occurred, which had an estimated peak discharge of $4,248 \mathrm{~m}^{3} / \mathrm{sec}$ (Griffiths, 1979). This flood is estimated to have a 100 year return period and was used as the design basis flood for the stopbank improvement scheme implemented in the 1960s.

Overall, the stopbanks along the Waimakariri River performed well during the earthquake, with only $\sim 4 \mathrm{~km}$ out of $\sim 17 \mathrm{~km}$ of stopbanks requiring repair (Boyle, 2010). The majority of the damage along the Waimakariri River was downstream of SH1 (Figure 6.3). Repairs to the high priority sites were expected to be completed within a few weeks after the earthquake, with medium priority sites expected to be completed in a couple of months. The cost of the repairs to the high and medium priority sites is estimated to be $\sim \$ N Z 3 \mathrm{~m}$ (Boyle, 2010).

Figures 6.4-6.9 are photographs of the stopbanks for the Waimakariri River along Coutts Island Rd. Numerous sand boils were found along the base of the stopbank for an $\sim 0.5$ $\mathrm{km}$ stretch (Figures 6.4-6.6), on both the river and land sides. By the time of the team's damage survey on 11 September 
2010 , the top of the stopbank along this stretch had already been regraded (Figure 6.7), likely to fill in longitudinal cracks that formed along the crest of the stopbank. Figure 6.8 is of a $\sim 20 \mathrm{~mm}$ wide longitudinal crack in the crest of the stopbank, located just outside of the $\sim 0.5 \mathrm{~km}$ stretch where the crest road had been regraded. It is assumed that the longitudinal cracks in the stretch of the stopbank where the crest road had been regraded were more significant than that crack shown in Figure 6.8, thus warranting the regrading. The liquefaction along the base of the stopbank and longitudinal cracks in the crest abruptly stopped outside of the $\sim 0.5 \mathrm{~km}$ stretch; this may be seen in Figure 6.9, where no damage to the stopbank could be found.

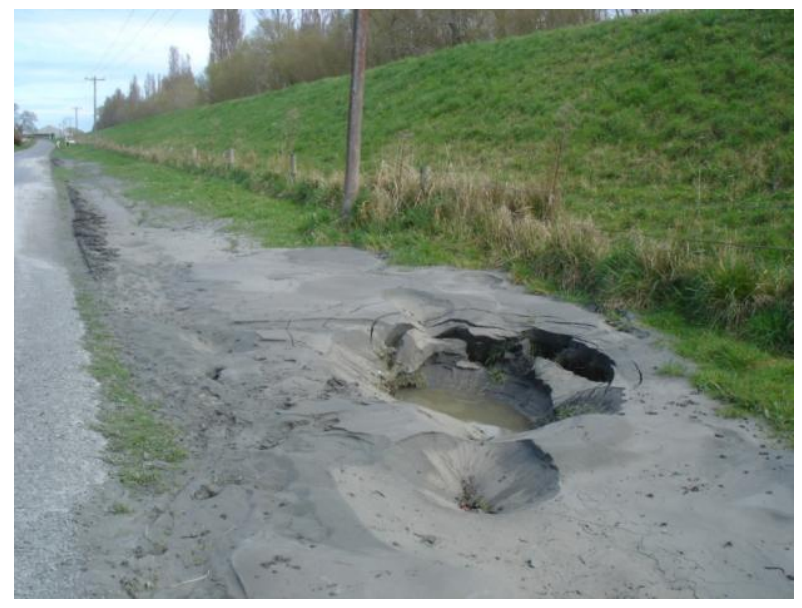

Figure 6.4: Photo 1: Large sand boil at the base of the landside of the stopbank on Coutts Island Rd. $\left(43.425018^{\circ} \mathrm{S}, 172.628442^{\circ} \mathrm{E}\right)$.

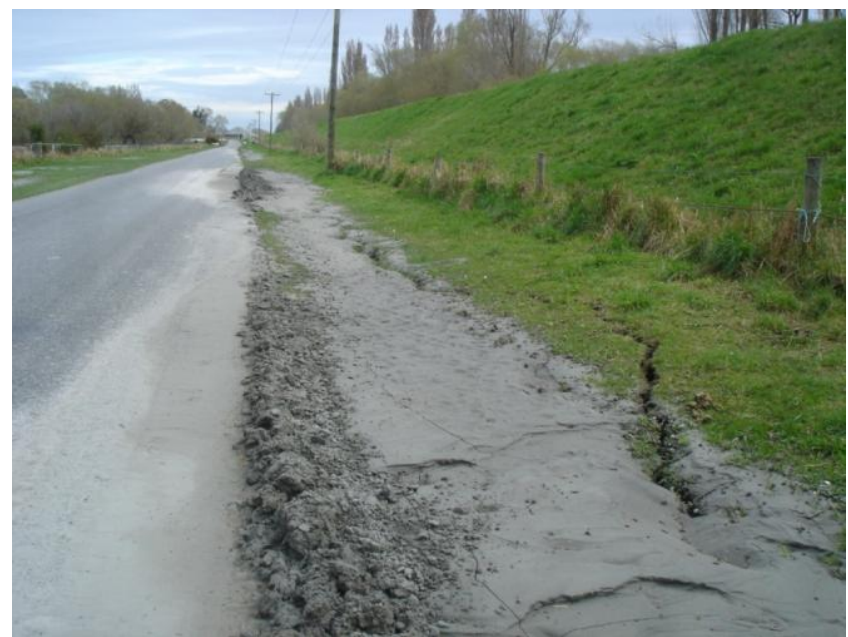

Figure 6.5: $\quad$ Photo 2: Crack running along base of stopbank on Coutts Island Rd (landside) and liquefaction ejecta. $\left(43.424466^{\circ} \mathrm{S}, 172.629907^{\circ} \mathrm{E}\right)$.

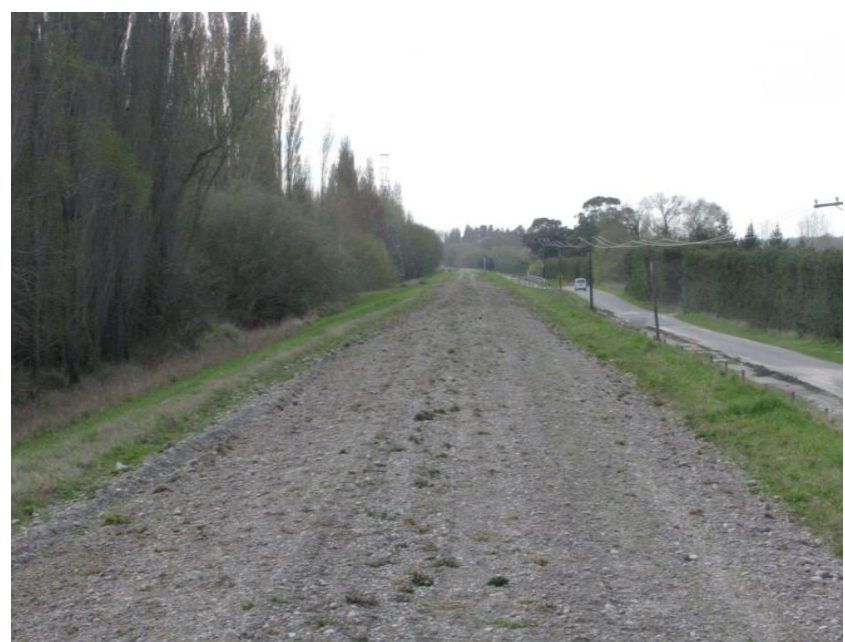

Figure 6.7: Photo 4: Road on top of stopbank that had recently been regraded, presumably after the earthquake to fill in longitudinal cracks formed during the earthquake. Liquefaction was observed along the base of both sides of the stopbank along this stretch. (43.423943 $\mathrm{S}$, $172.631045^{\circ} \mathrm{E}$ ).

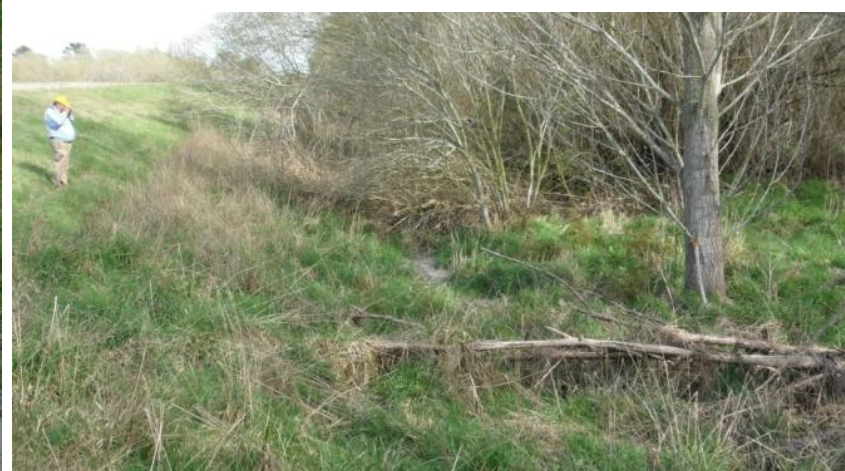

Figure 6.6: Photo 3: Liquefaction ejecta (centre of photo) along the base of the stopbank on Coutts Island $R d$ (riverside). $\left(43.424093^{\circ} \mathrm{S}, 172.630468^{\circ} \mathrm{E}\right.$ ).

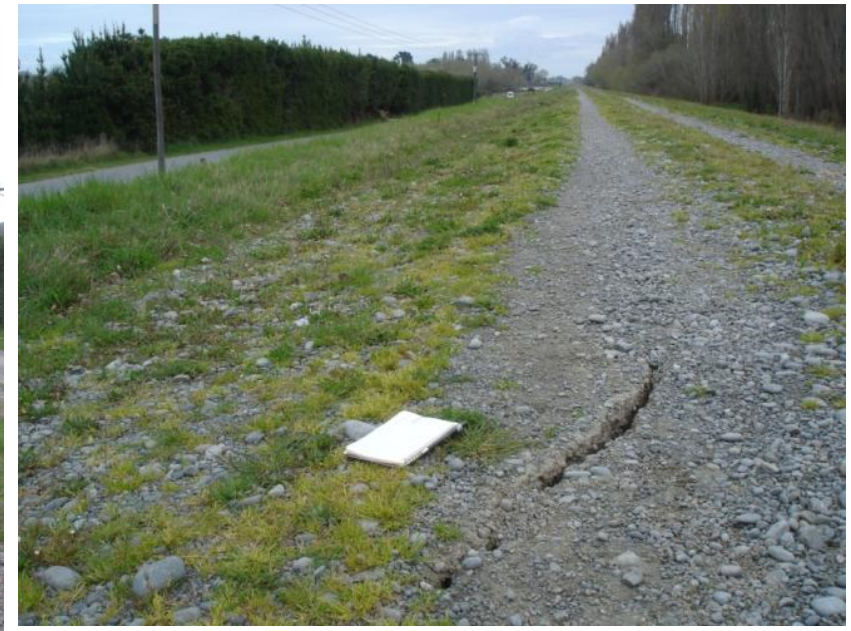

Figure 6.8: Photo 5: $\sim 20 \mathrm{~mm}$ wide crack running lengthwise along the top of the stopbank on Coutts Island $R d$. This crack was at the edge of the $\sim 0.5 \mathrm{~km}$ stretch of the stopbank where significant liquefaction was observed. Photo taken looking southwest $\left(43.423440^{\circ} \mathrm{S}, 172.632349^{\circ} \mathrm{E}\right)$. 
From interviews with local land owners, this section of the land that experienced widespread liquefaction was part of an old river channel. This was confirmed by review of old maps of the area. Figure 6.10 is an aerial image of the Coutts Island Rd area with the 1865 south branch of the Waimakariri River channel highlighted in red. The $\sim 0.5 \mathrm{~km}$ stretch of the stopbank where liquefaction was observed is denoted by the dashed yellow line (A) in this figure. As may be seen in this figure, the area that liquefied coincides with the location of the old river channel, while the stretches of stopbank with no observed liquefaction (dashed blue line) lie outside of the old river channel.
Three Dynamic Cone Penetration Tests (DCPT) and four Spectral Analysis of Surface Waves (SASW) tests were performed along the base of the stopbanks along Coutts Island Rd, both in the areas that did and did not liquefy (Figure 6.11). The results of these tests are presented in Figures 6.12-6.14 The DCPT is performed in a hole hand augered down to the top of the liquefied layer, with this layer identified by comparing sand boil ejecta with soil extracted with the auger at various depths. The test is performed until there was a noticeable increase in the DCPT N-value or we ran out of rods $(\sim 4.6 \mathrm{~m}$ from the top of the ground surface. (See the Liquefaction and Lateral Spreading chapter for a more detailed description of the DCPT test)

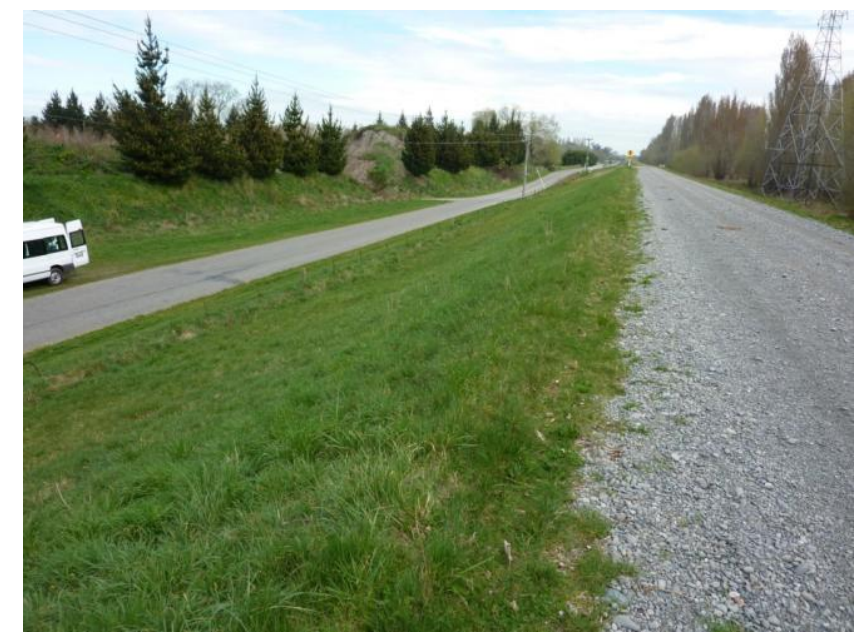

Figure 6.9: Photo 6: Stretch of stopbank without evidence of liquefaction. In the distance, a small rise can be seen in the road. This rise is the start of the $\sim 0.5 \mathrm{~km}$ stretch where liquefaction was observed along the base of the stopbank. $\left(43.4225^{\circ} \mathrm{S}, 172.6350^{\circ} \mathrm{E}\right)$.

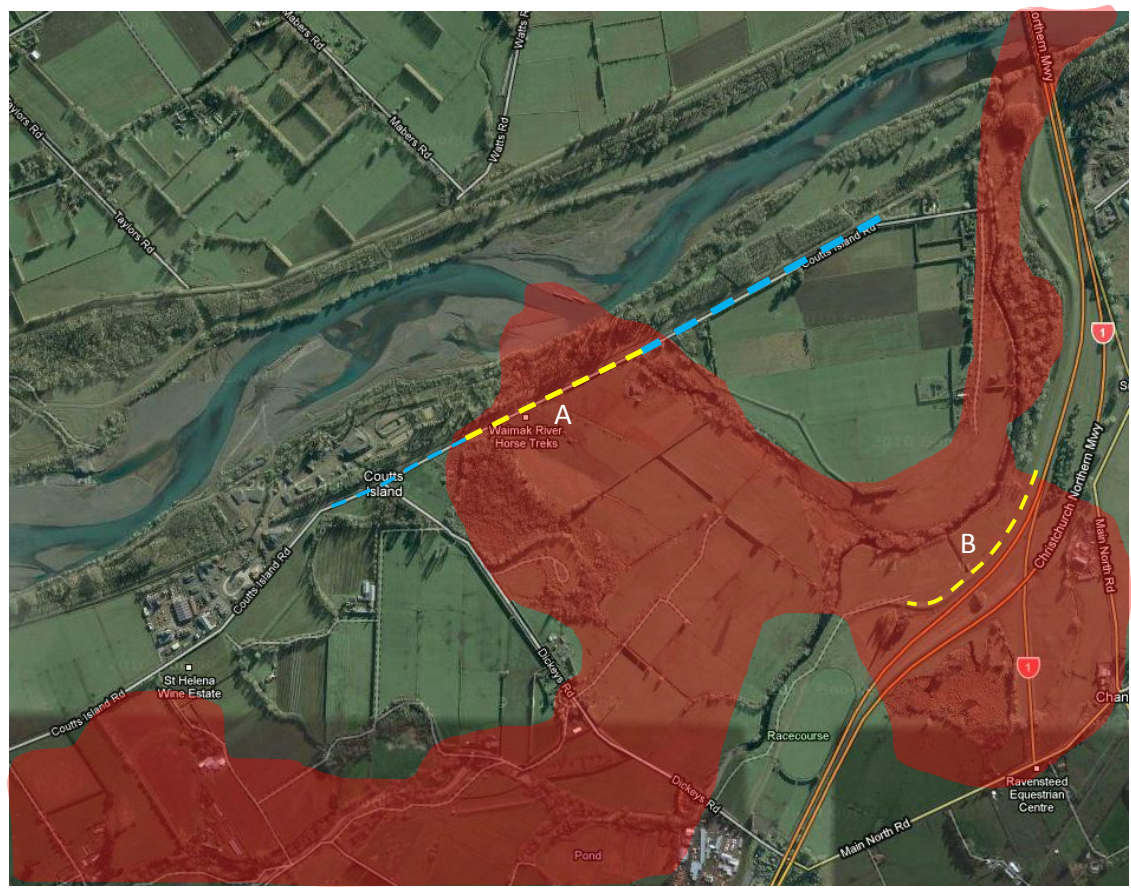

Figure 6.10: Overlay of 1865 stream channel on present day Coutts Island Rd. This image is $\sim 3.5 \mathrm{~km}$ across (centre $43.4266^{\circ} \mathrm{S}$, 172.6302 ${ }^{\circ}$ E) (Google Inc. 2010). 

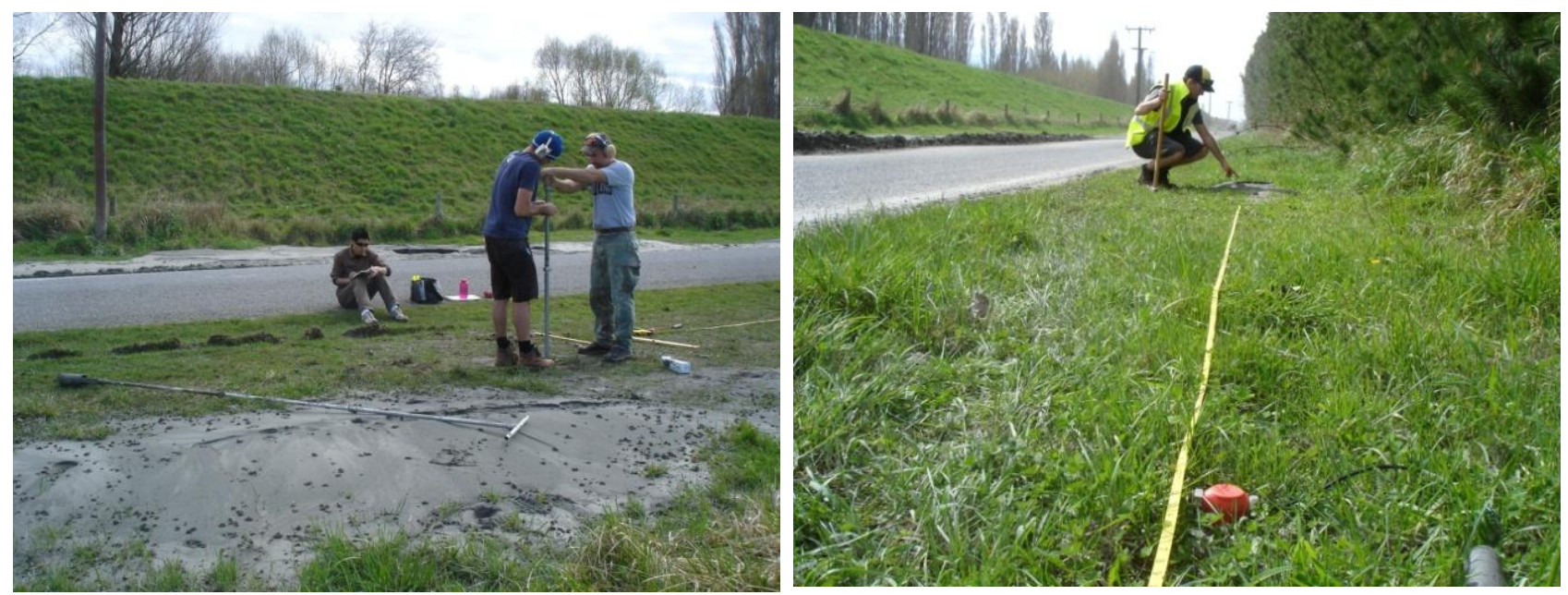

Figure 6.11: Photos 7 and 8: DCPT (left: $43.425137^{\circ} \mathrm{S}, 172.62861^{\circ} \mathrm{E}$ ) and SASW test (right: $43.424342^{\circ} \mathrm{S}, 172.630473^{\circ} \mathrm{E}$ ) performed in areas that did and did not liquefy along the stopbank on Coutts Island Rd .

Shear Wave Velocity, $\mathrm{m} / \mathrm{s}$

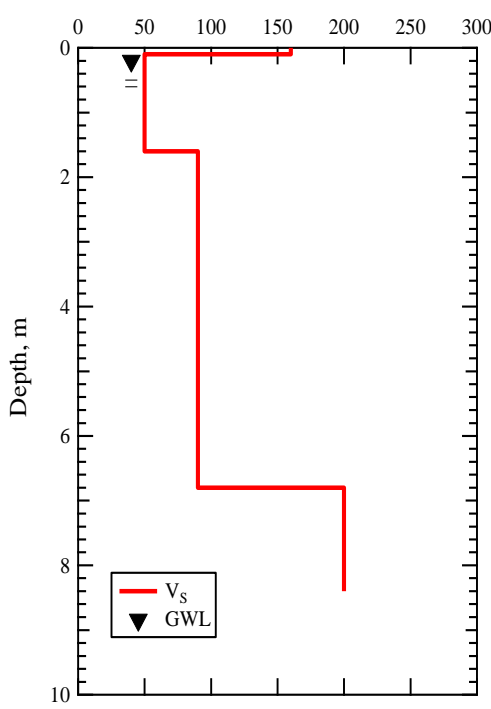

Shear Wave Velocity, $\mathrm{m} / \mathrm{s}$

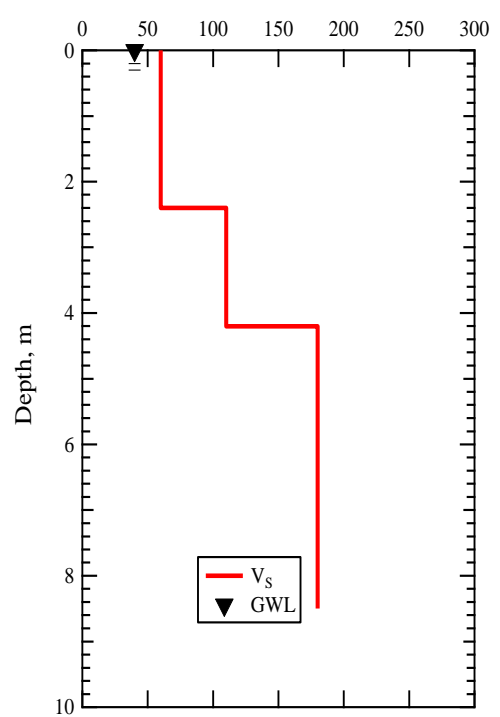

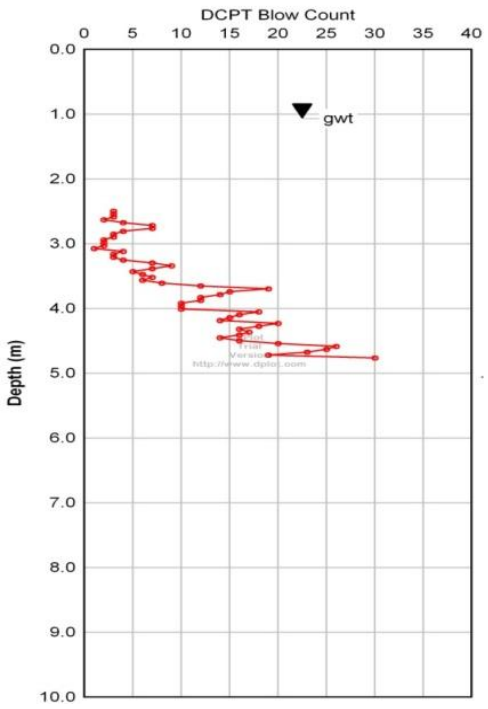

Figure 6.12: $\quad$ Results from SASW tests (left: $S A S W 143.425029^{\circ} \mathrm{S}, 172.628676^{\circ} \mathrm{E}$; middle: $S A S W 343.424351^{\circ} \mathrm{S}, 172.630475^{\circ} \mathrm{E}$ ) and DCPT (right: DCPT1 $43.425139^{\circ} S, 172.628618^{\circ}$ E) performed along the base of the stopbank on Coutts Island Rd in an area that liquefied.

Shear Wave Velocity, $\mathrm{m} / \mathrm{s}$
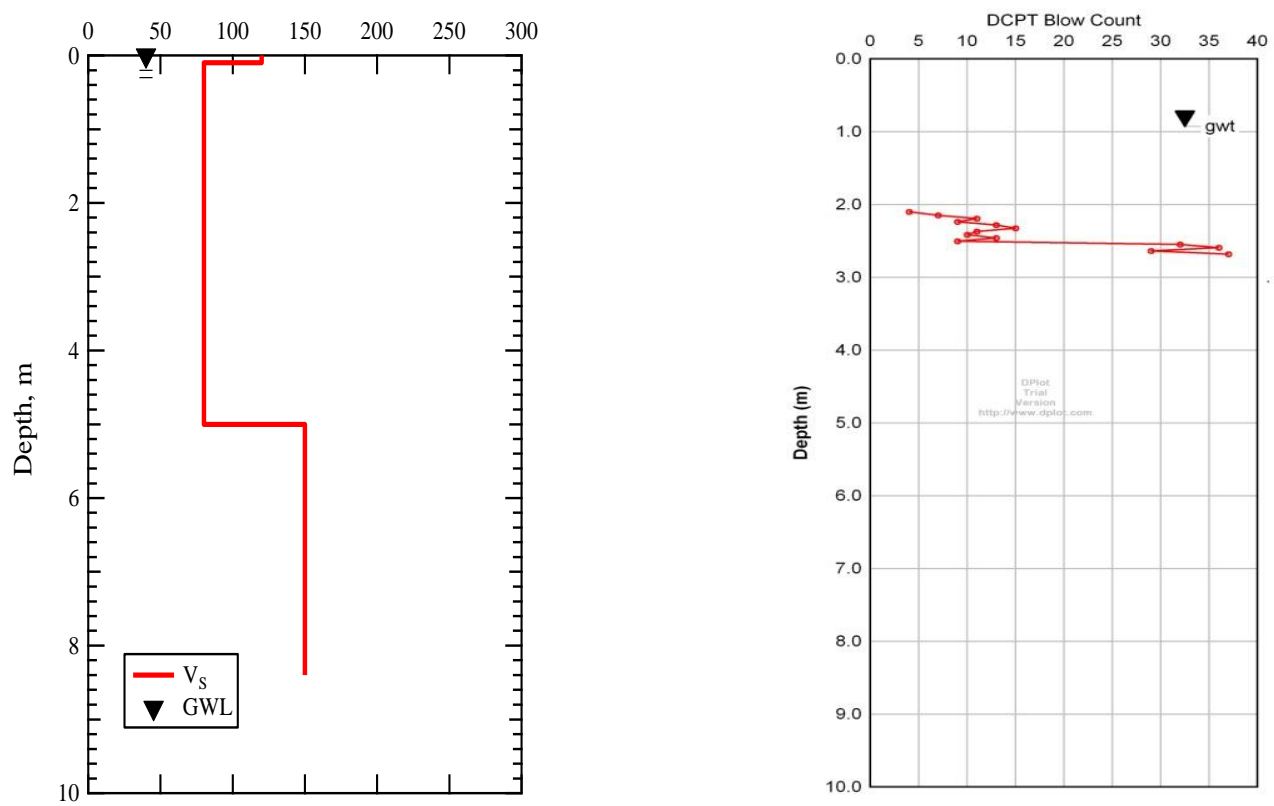

Figure 6.13: Results from SASW test (left: SASW2 $43.426294^{\circ} \mathrm{S}, 172.625439^{\circ} \mathrm{E}$ ) and DCPT (right: $\mathrm{DCPT1} 43.426186^{\circ} \mathrm{S}$, $172.625673^{\circ} \mathrm{E}$ ) performed along the base of the stopbank on Coutts Island Rd in an area that did not liquefy. 

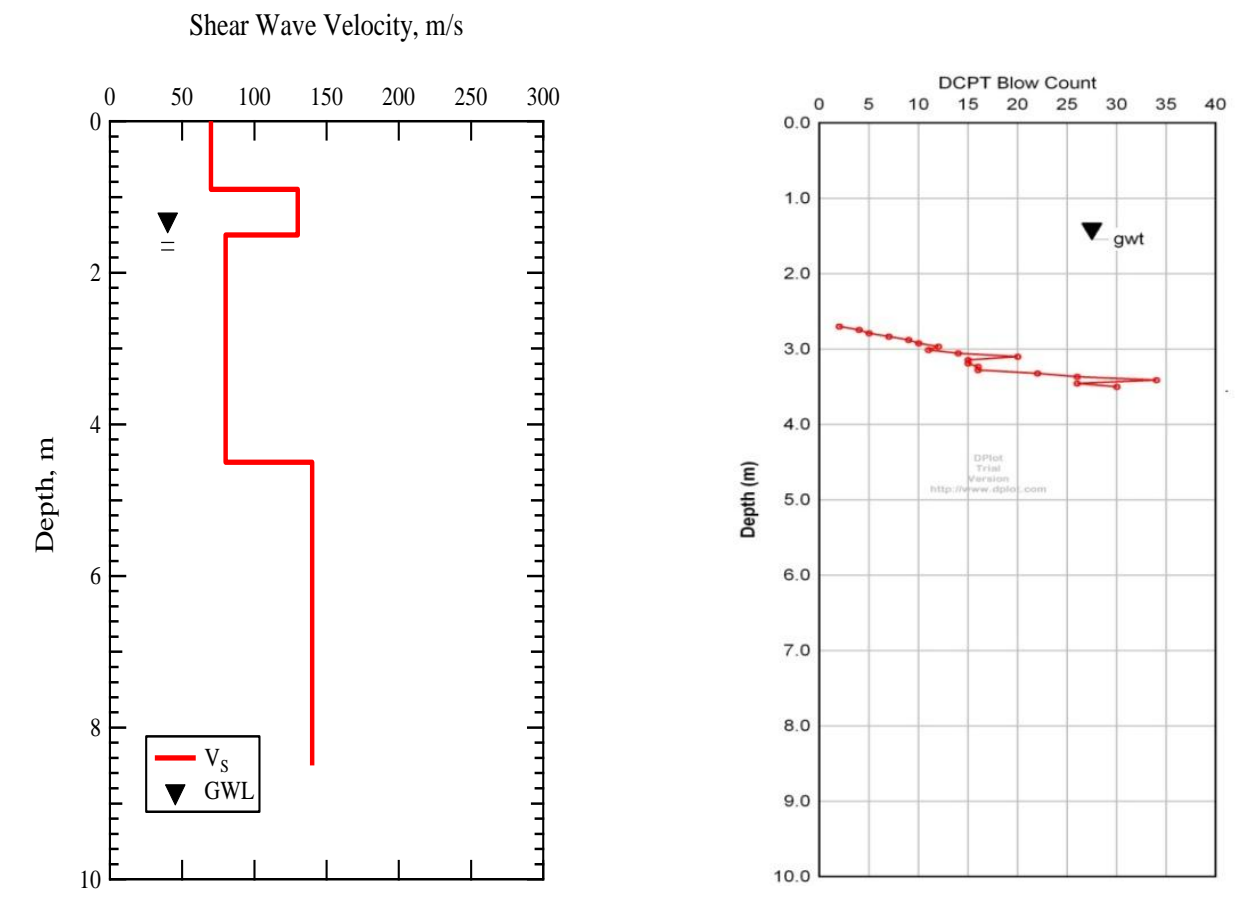

Figure 6.14: Results from SASW test (left: SASW4 $43.422635^{\circ} \mathrm{S}, 172.635038^{\circ} \mathrm{E}$ ) and DCPT (right: DCPT3 $43.422685^{\circ} \mathrm{S}$, $172.635081^{\circ}$ E) performed along the base of the stopbank on Coutts Island Rd in an area that did not liquefy.
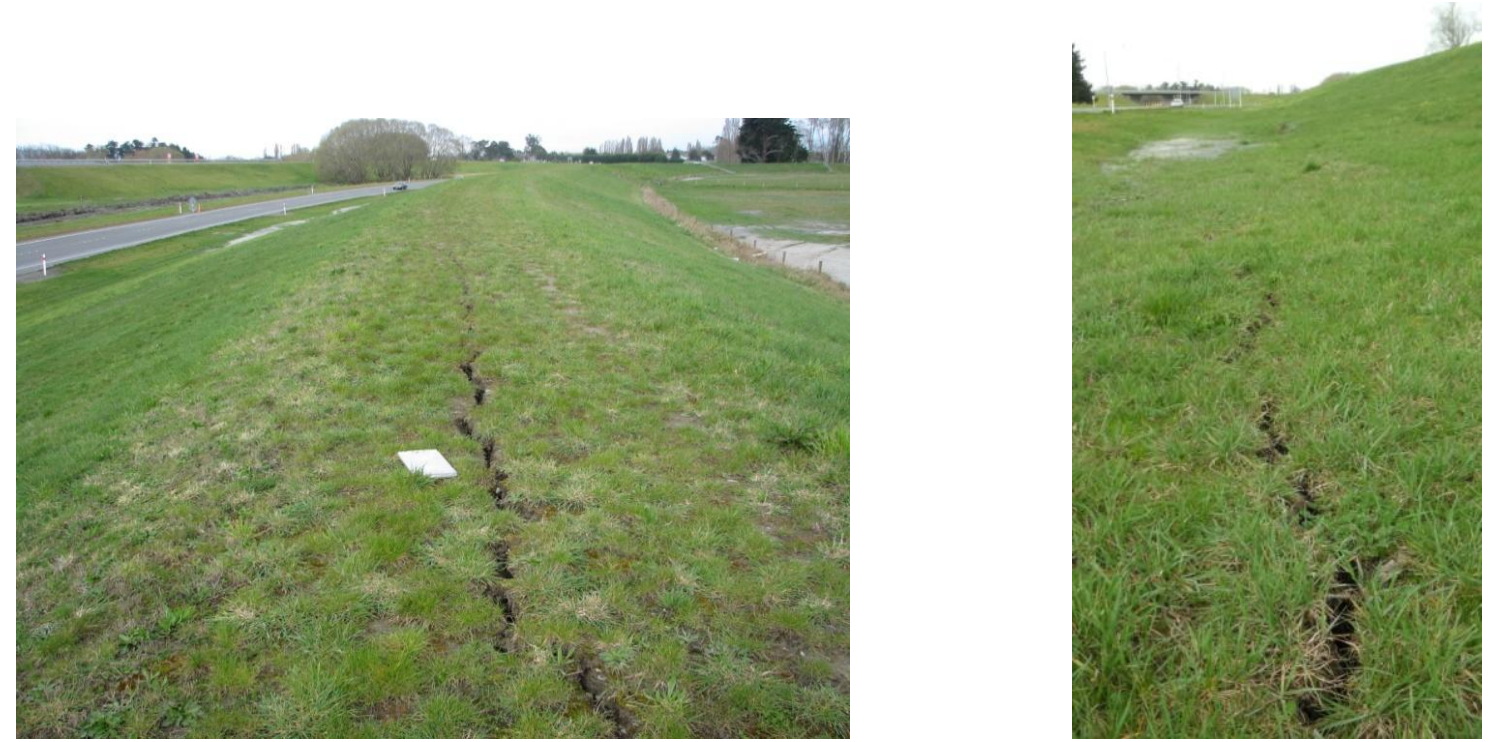

Figure 6.15: Photos 9 and 10: $~ 50$ mm wide longitudinal cracks running along the crest (left) and base (right) of a secondary stopbank for the Waimakariri River. Photo taken looking southwest; SH1 on left of stopbank $\left(43.430108^{\circ}\right.$, $\left.172.643434^{\circ} \mathrm{E}\right)$.

Other than SASW3 and DCPT1, performed about $175 \mathrm{~m}$ from each other in an area that liquefied, the agreement between the SASW and DCPT results is not very good in terms of depth to a stiff, presumably nonliquefiable layer. Further analyses are required to fully understand why. However, the sites that did not liquefy were along the banks of the old river channel. A liquefiable layer could not be found in these areas using the hand auger, and the soil profiles (DCPT2 and DCPT3) consisted of clayey sand and peat. Given the depositional environment of these profiles, it is likely that the strata varied significantly laterally, which could be the explanation for the poor agreement between the DCPT and SASW test results.

Figures 6.15 and 6.16 are photographs of a secondary stopbank for the Waimakariri River along State Highway 1. This stretch of the stopbank is denoted by a dashed yellow line (B) in Figure 6.10. Liquefaction was observed on both sides of the stopbank and longitudinal cracks were observed running along the crest and sides of the stopbank (Figures 6.15 and 6.16). As may be seen from Figure 6.10, this stretch of the stopbank lies within the abandoned river channel of the old south branch of the Waimakariri River.

\subsubsection{Kaiapoi River stopbanks}

Kaiapoi is located at the north-eastern end of the Canterbury Plains, about $20 \mathrm{~km}$ north of Christchurch. The Kaiapoi River used to be a part of the eastern reach of the old north branch of the Waimakariri River (Griffiths, 1979) and cuts through the centre of Kaiapoi. The Kaiapoi River joins the Waimakariri River on the eastern edge of town and flows to the sea (Figure 6.2). Liquefaction was widespread along the northern and southern banks of the Kaiapoi River and adjacent neighbourhoods. 

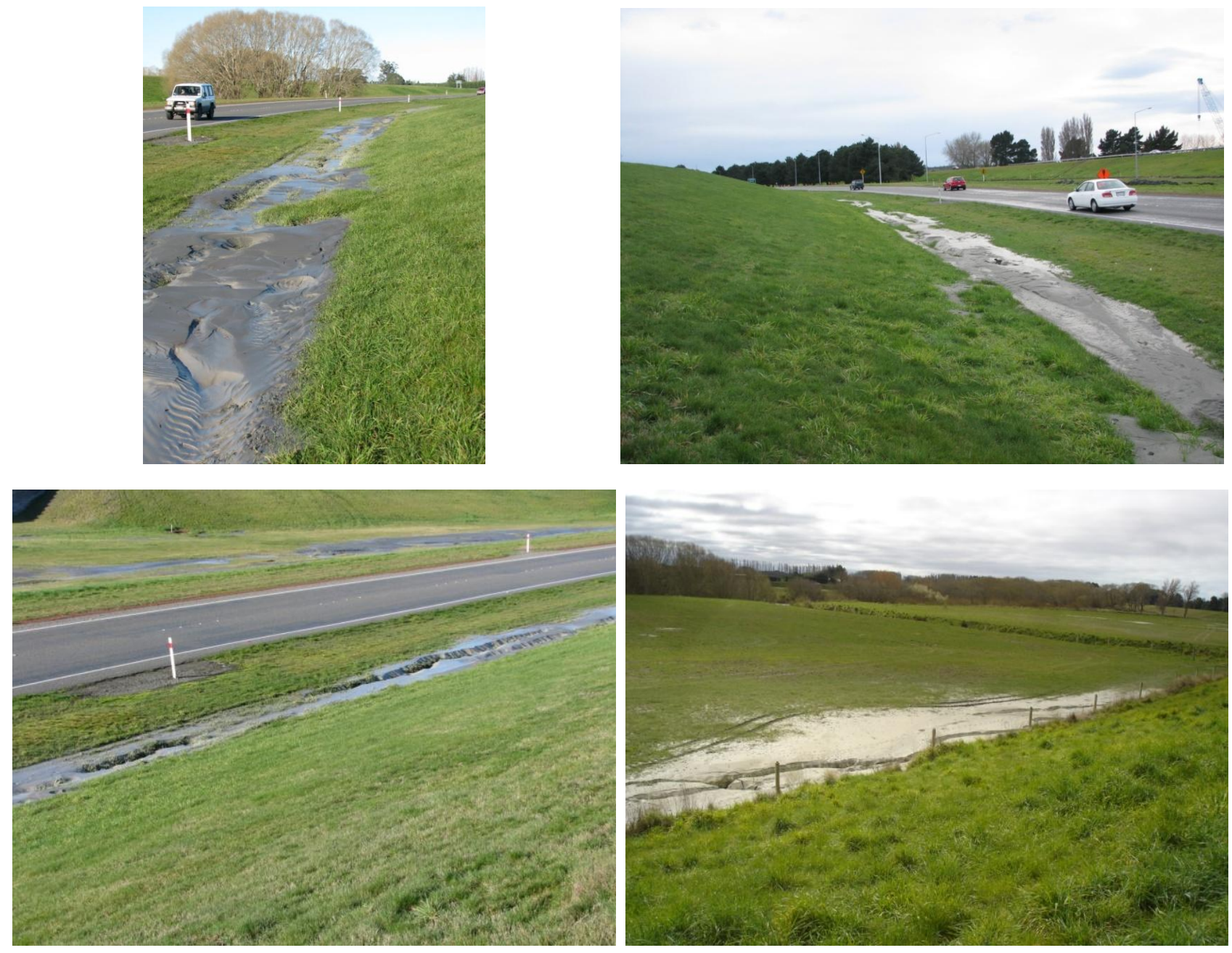

Figure 6.16: Photos 11 to 14: Liquefaction ejecta on both the river and landsides of the stopbank. $\left(43.428968^{\circ} \mathrm{S}, 172.645435^{\circ} \mathrm{E}\right)$.

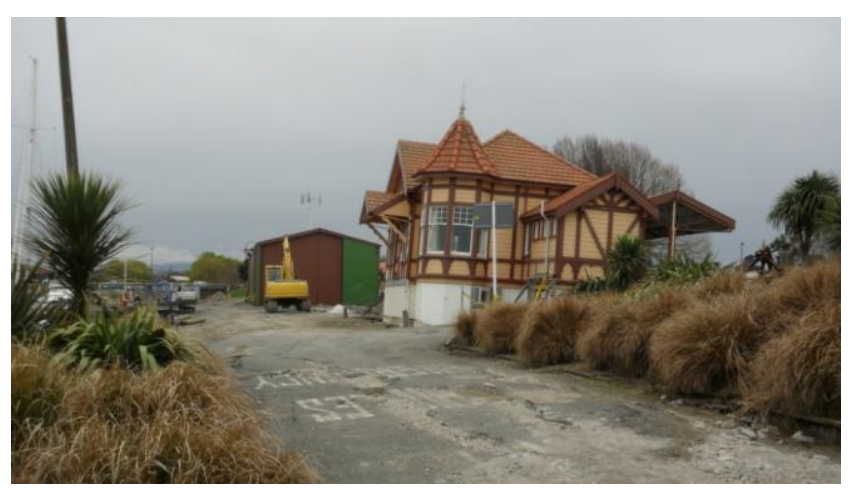

Figure 6.17: Photo 15: Visitors Information Centre on the stopbank on the north side of the Kaiapoi River. The location of this photograph is denoted in Figure 6.2. (43.387384 $\left.{ }^{\circ} \mathrm{S}, 172.659743^{\circ} \mathrm{E}\right)$.

The stopbanks confining the flow of the Kaiapoi River suffered damage at various locations (Figure 6.3). These embankments, measuring about $2.5 \mathrm{~m}$ high (from the water line at the time of our observations) and $2.7 \mathrm{~m}$ wide, have slopes of approximately $2 \mathrm{H}: 1 \mathrm{~V}$ on the riverside and $3 \mathrm{H}: 1 \mathrm{~V}$ on the landside near the Williams St. bridge, which remained serviceable after the earthquake despite incipient liquefaction in the abutments and settlement and cracking of the approach on the eastern side of the bridge.

In downtown Kaiapoi adjacent to the river, the Visitors' Information Centre on the north side of the river sank and tilted as a result of liquefaction and lateral spreading (Figure 6.17). Ground cracks, as wide as $300 \mathrm{~mm}$ and as deep as $1 \mathrm{~m}$, were observed running parallel to the river near this structure. The two-storey Waimakariri-Ashley Coastguard building adjacent to the Visitor Centre also suffered the same effects. Just east of this building ( $100 \mathrm{~m})$, ground cracks, on the order of $1 \mathrm{~m}$ wide and $1.85 \mathrm{~m}$ deep were also observed along the gentle inboard (land-side) slope of the stopbank (Figure 6.18). Lateral spread cracks with massive ejecta were observed at the toe of the embankment (Figure 6.19). Also, a skate park that was located about midway up the gently sloping inboard side of the stopbank was severely damaged by lateral spreading (Figure 6.20). Settlement/slumping of the foot path on the crest of the stopbank on the order of 100-300 mm were also noted. Detailed maps of the largest lateral spread cracks will be provided in subsequent versions of this report. 
Two bore holes were made using a hand auger near the lateral spread cracks $\left(43.384767^{\circ} \mathrm{S}, 172.661133^{\circ} \mathrm{E}\right.$ and $43.384683^{\circ} \mathrm{S}$, $\left.172.661350^{\circ} \mathrm{E}\right)$. However, the profile largely consisted of random fill (gravels/cobbles and wood), making it difficult to advance the auger. One of the bore holes went down to a depth of $\sim 5.5 \mathrm{~m}$, yet a thick layer of soil matching the liquefaction ejecta material could not be found. However, thin $(<100 \mathrm{~mm})$ alternating layers of loose saturated sand and very wet, very soft clay/plastic silt were encountered, particularly near the large lateral spread crack shown in Figure 6.18. This lateral spread crack had no trace of ejecta in and/or immediately near it. This crack was closer to the river than ones that were filled with ejecta at the toe of the stopbank $\sim 30 \mathrm{~m}$ away (Figure
6.19).

Houses across from the stopbank on Charles St underwent significant earthquake-induced settlement. This damage is discussed in detail in the Impact on Structures chapter.

Further east along the Kaiapoi River $(\sim 400 \mathrm{~m})$, the ground adjacent to a $6 \mathrm{~m}$ diameter structure (containing an underground tank and control equipment) settled by about 300 $\mathrm{mm}$, resulting in damage to pipes attached to the tank (Figure 6.21). Additionally, aerial photographs of lateral spreading along the north bank of the Kaiapoi River going east from the town centre are shown in Figure 6.22.
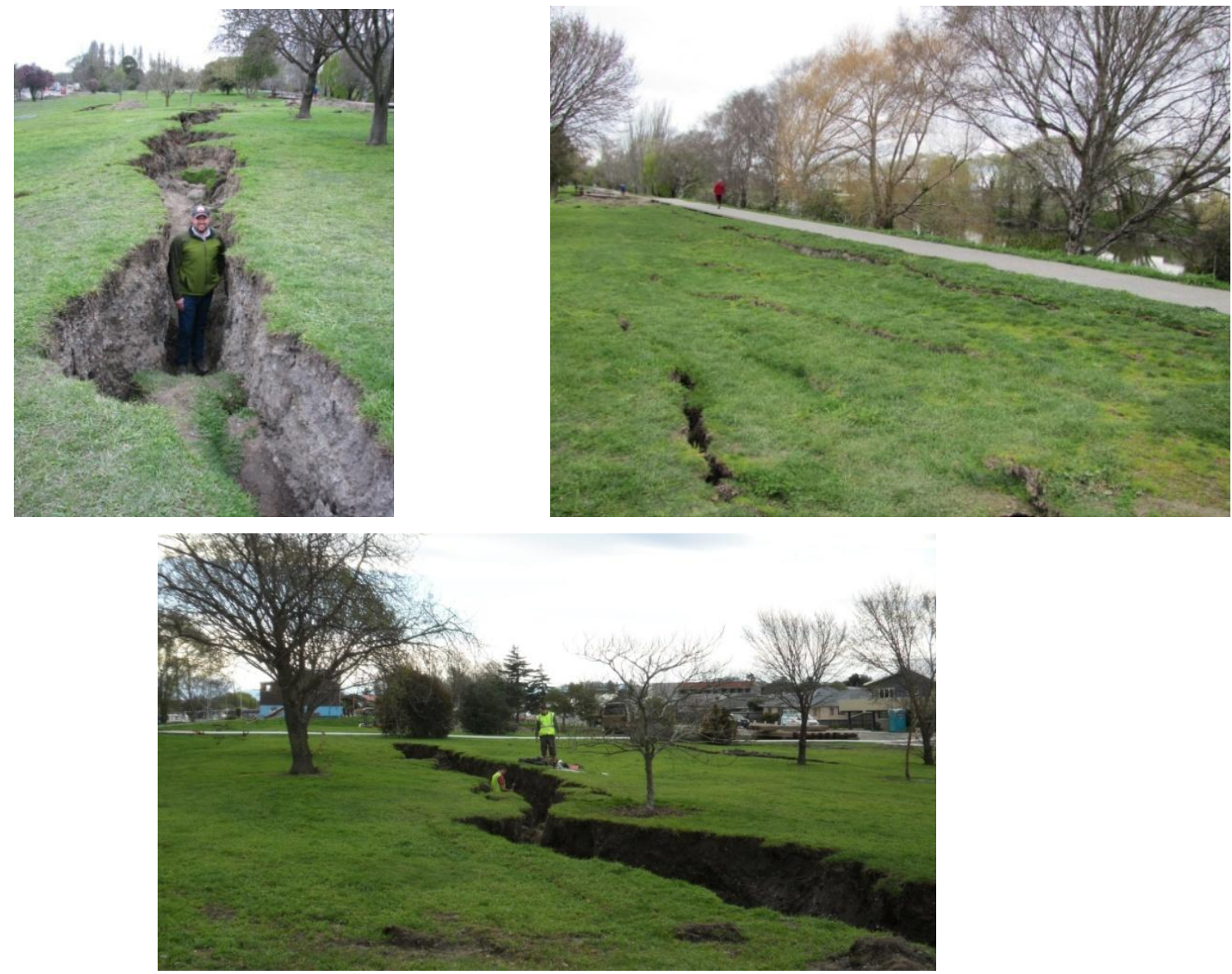

Figure 6.18: Photos 16-18: Lateral spread cracks along landside of the stopbank on the north side of the Kaiapoi River. The locations of these photographs are denoted in Figure 6.2. $\left(43.384484^{\circ} \mathrm{S}, 172.660653^{\circ} \mathrm{E}\right)$.
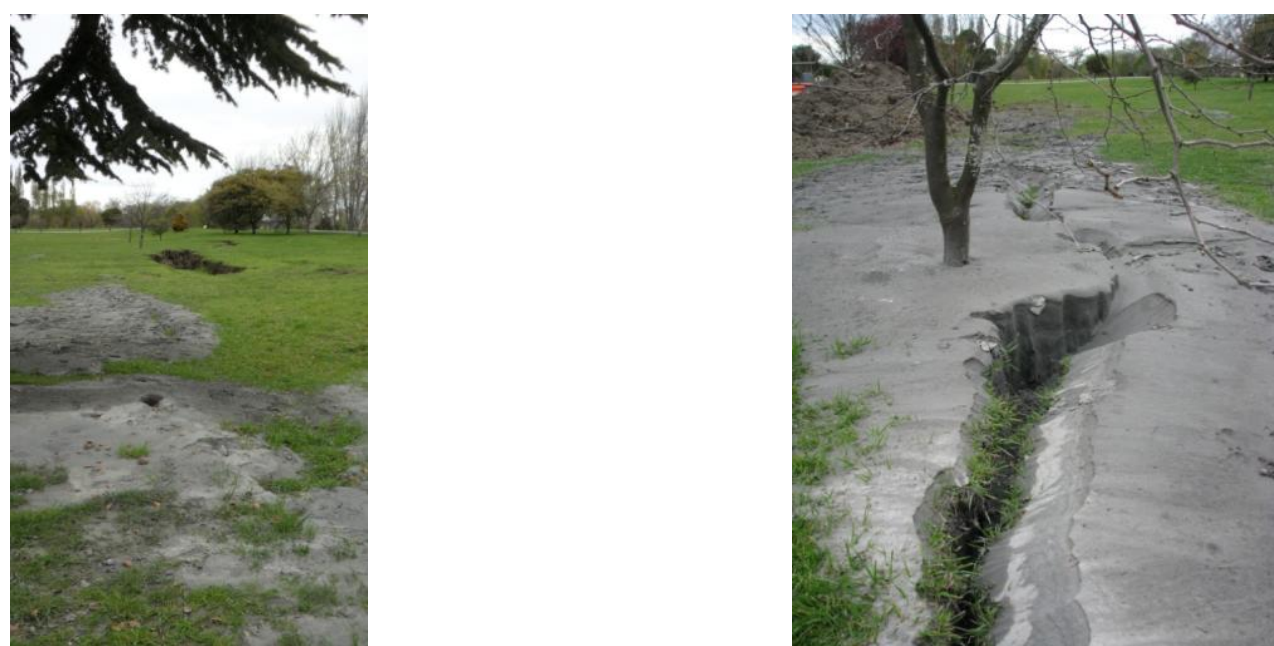

Figure 6.19: Photos 19-20: Lateral spreading cracks along the landside of the stopbank on the north side of the Kaiapoi River. The locations of these photographs are denoted in Figure 6.2. $\left(43.384633^{\circ} \mathrm{S}, 172.661231^{\circ} \mathrm{E}\right)$. 


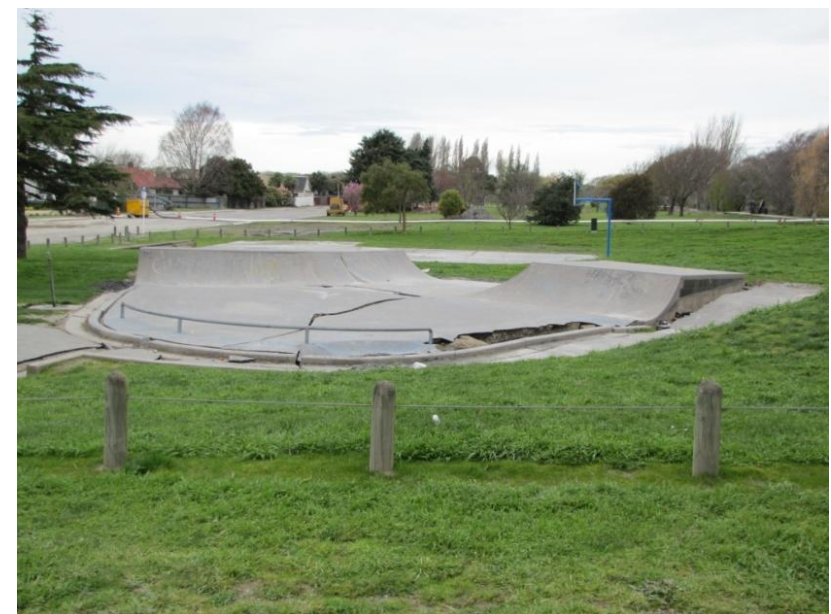

Figure 6.20: Photo 21: Skate park on the stopbank on the north side of the Kaiapoi River. The location of this photograph is denoted in Figure 6.2. $\left(43.384094^{\circ} \mathrm{S}, 172.660370^{\circ} \mathrm{E}\right)$.

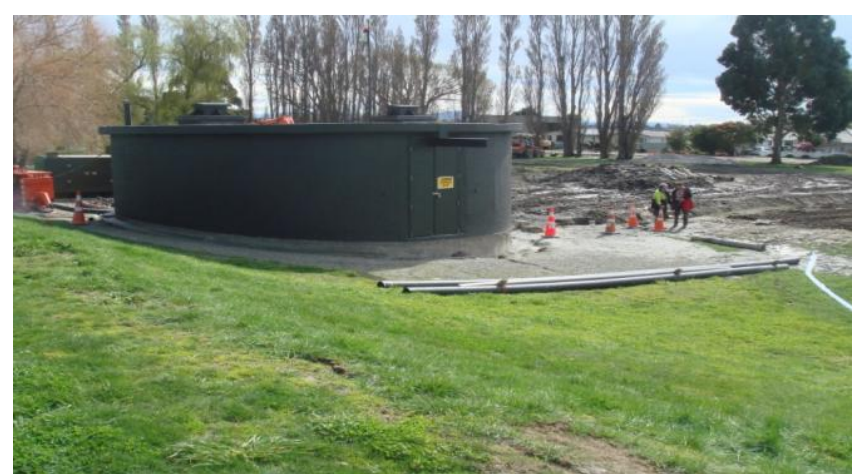

Figure 6.21: Photo 22: Settlement of tank structure. The locations of these photographs are denoted in Figure 6.2. $\left(43.386918^{\circ} \mathrm{S}, 172.664412^{\circ} \mathrm{E}\right)$.
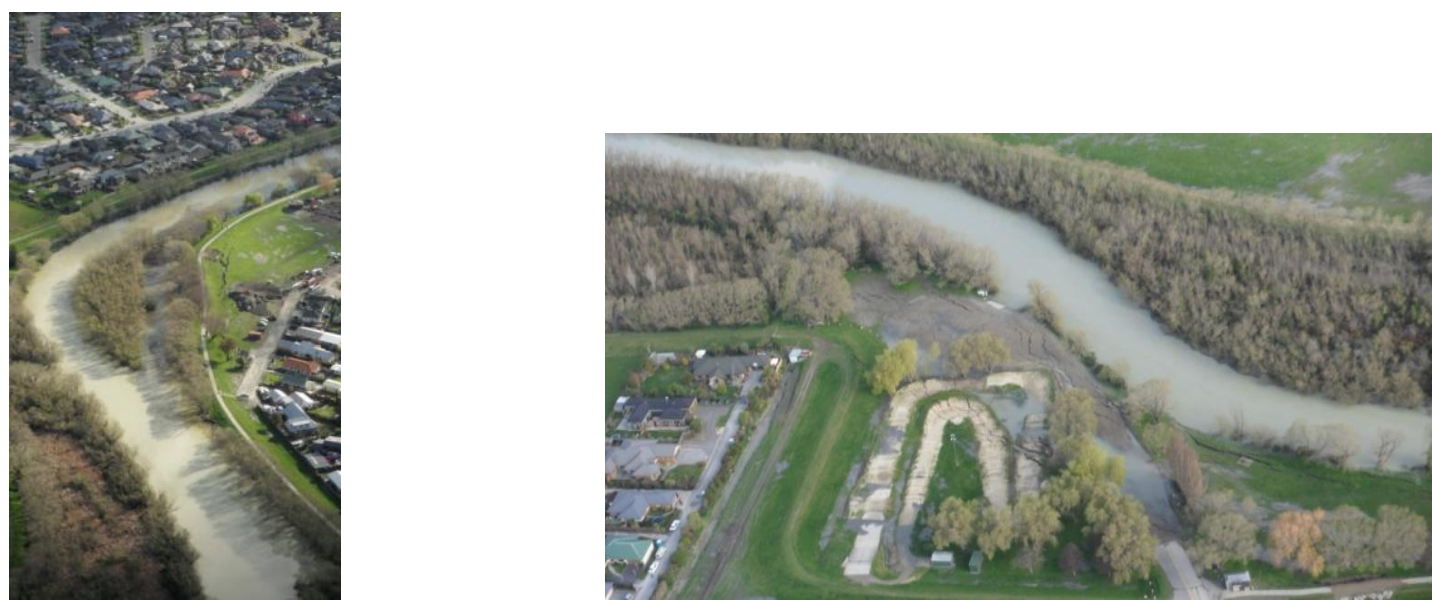

Figure 6.22: Photos 23 \& 24: Aerial photographs of lateral spreading of stopbanks on the north bank of the Kaiapoi River. The locations of these photographs are denoted in Figure 6.2. (left: $43.387389^{\circ} \mathrm{S}, 172.666173^{\circ} \mathrm{E}$; right: $43.386875^{\circ} \mathrm{S}$, 172.672297 $\mathrm{E})$.

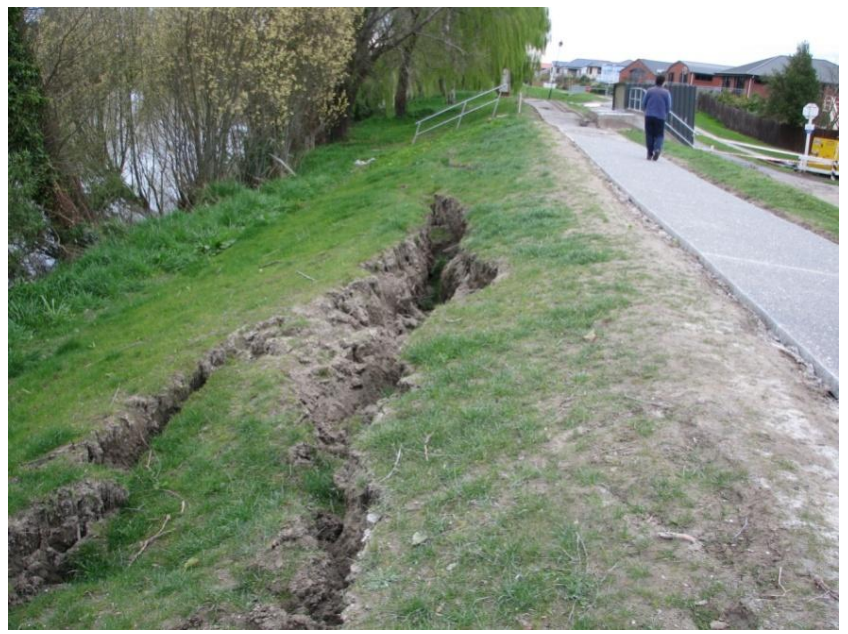

Figure 6.23: Photo 25: Lateral spread cracks along riverside stopbank on the south side of the Kaiapoi River. The location of this photograph is denoted in Figure 6.2. $\left(43.385254^{\circ} \mathrm{S}, 172.660131^{\circ} \mathrm{E}\right)$.

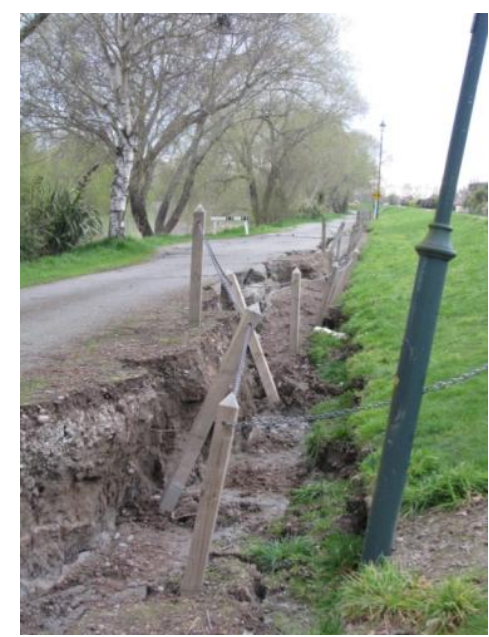

Figure 6.24: Photo 26: Lateral spread cracks along the riverside stopbank on the south side of the Kaiapoi River. The location of this photograph is denoted in Figure 6.2. $\left(43.385839^{\circ} \mathrm{S}, 172.660941^{\circ} \mathrm{E}\right)$. 


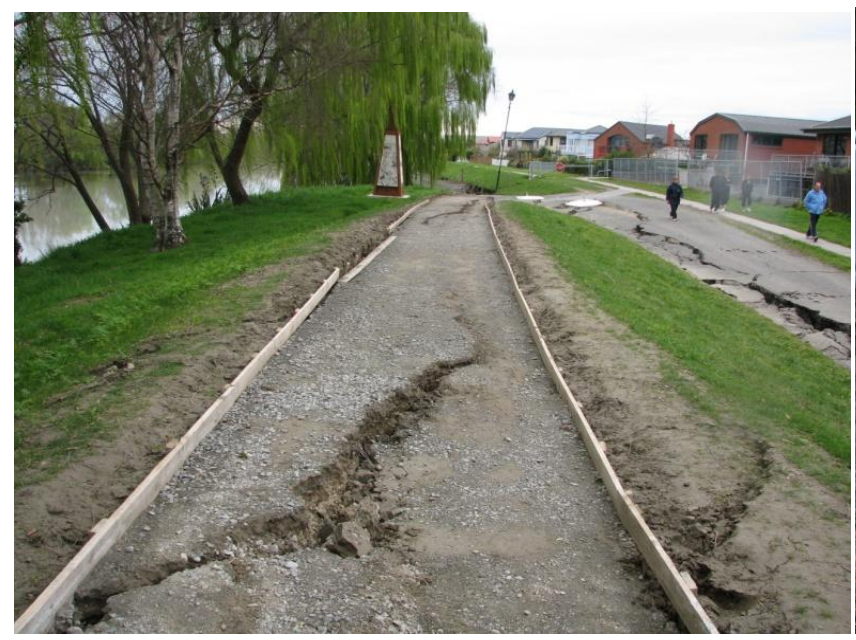

Figure 6.25: Photo 27: Lateral spread cracks along the top of the stopbank on the south side of the Kaiapoi River. The location of this photograph is denoted in Figure 6.2. $\left(43.385693^{\circ} \mathrm{S}, 172.660688^{\circ} \mathrm{E}\right)$.

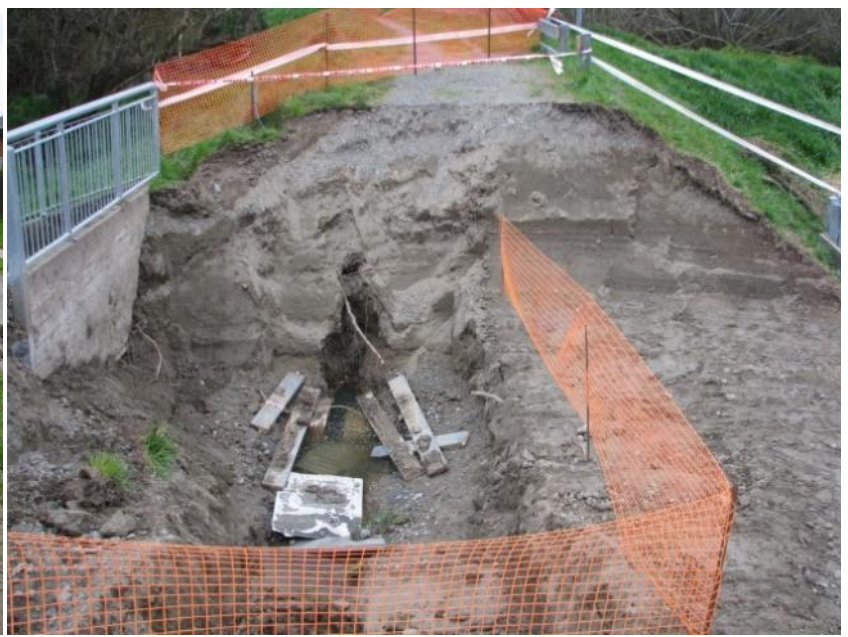

Figure 6.26: Photo 28: Failed drainage conduits running underneath the stopbank on the south side of the Kaiapoi River. The location of this photograph is denoted in Figure 6.2. $\left(43.388679^{\circ} \mathrm{S}\right.$, 172.666203 ${ }^{\circ} \mathrm{E}$ )

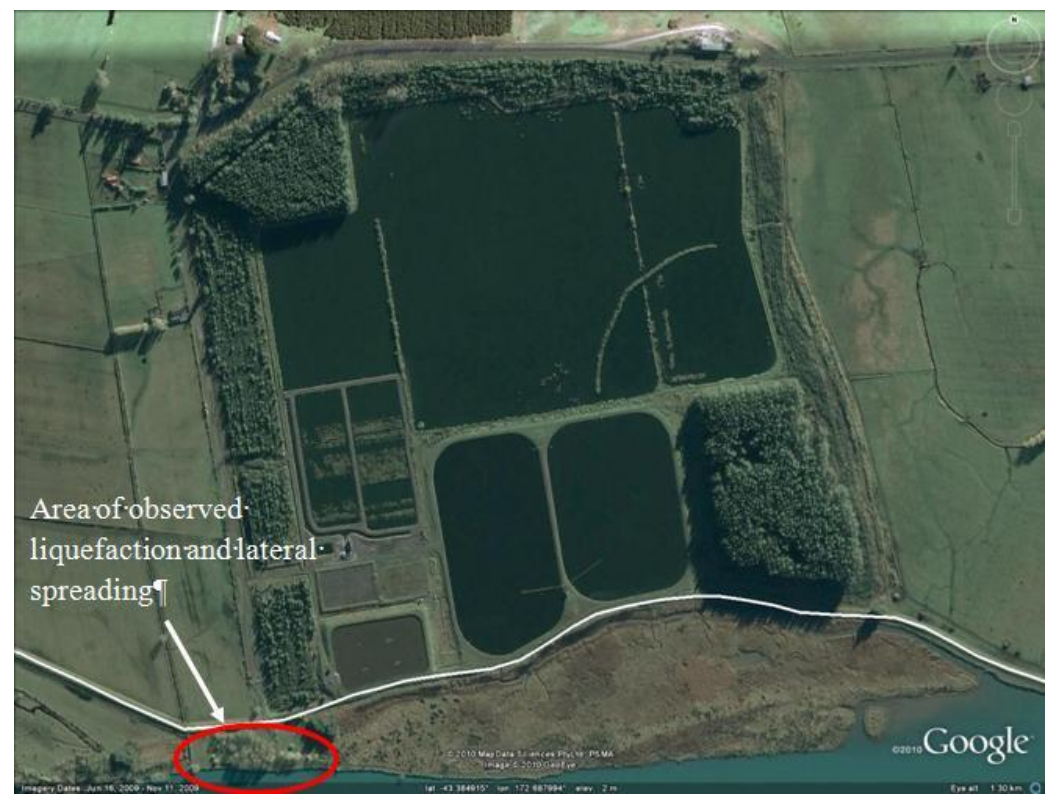

Figure 6.27: Aerial image of the Kaiapoi Sewage Treatment Plant. The southern perimeter ( 0.6 km) of the oxidation ponds (bottom of image) forms the stopbanks of the north side of the Waimakariri River. $\left(43.384583^{\circ} \mathrm{S}, 172.688240^{\circ} \mathrm{E}\right)$.

The stopbank along the south bank of the Kaiapoi River also experienced extensive lateral cracking, and the adjacent homes on Raven Quay experienced significant post-earthquake settlement. Figures 6.23-6.26 are photographs of the stopbank on the south bank of the river.

\subsection{Seismic Performance of Oxidation Pond Embankments}

The geotechnical reconnaissance team also performed damage surveys on foot at the sewage treatment plant oxidation pond embankments in Bromley and Kaiapoi.

\subsubsection{Kaiapoi Sewage Treatment Plant}

The Kaiapoi Sewage Treatment Plant, operated by the Waimakariri District Council, is located between Kaiapoi and Pines Beach and is bordered to the south by the Waimakariri River stopbank. From 2001 to 2003, the average and peak daily inflows were 3,235 and $10,695 \mathrm{~m}^{3} /$ day, respectively, and the average and peak daily outflows were 1,163 and 5,565 $\mathrm{m}^{3} /$ day, respectively (CH2M Beca Ltd., 2003). An aerial image of the plant is shown in Figure 6.27.

The geotechnical reconnaissance team performed a damage survey on foot of the stopbanks along the southern perimeter of the plant, denoted by the white line in Figure 6.27. No damage was observed along this stretch of the stopbanks, although the team observed large lateral spread cracks $(\sim 300$ $\mathrm{mm}$ wide) in the stopbanks and shoreline about $100 \mathrm{~m}$ west of 

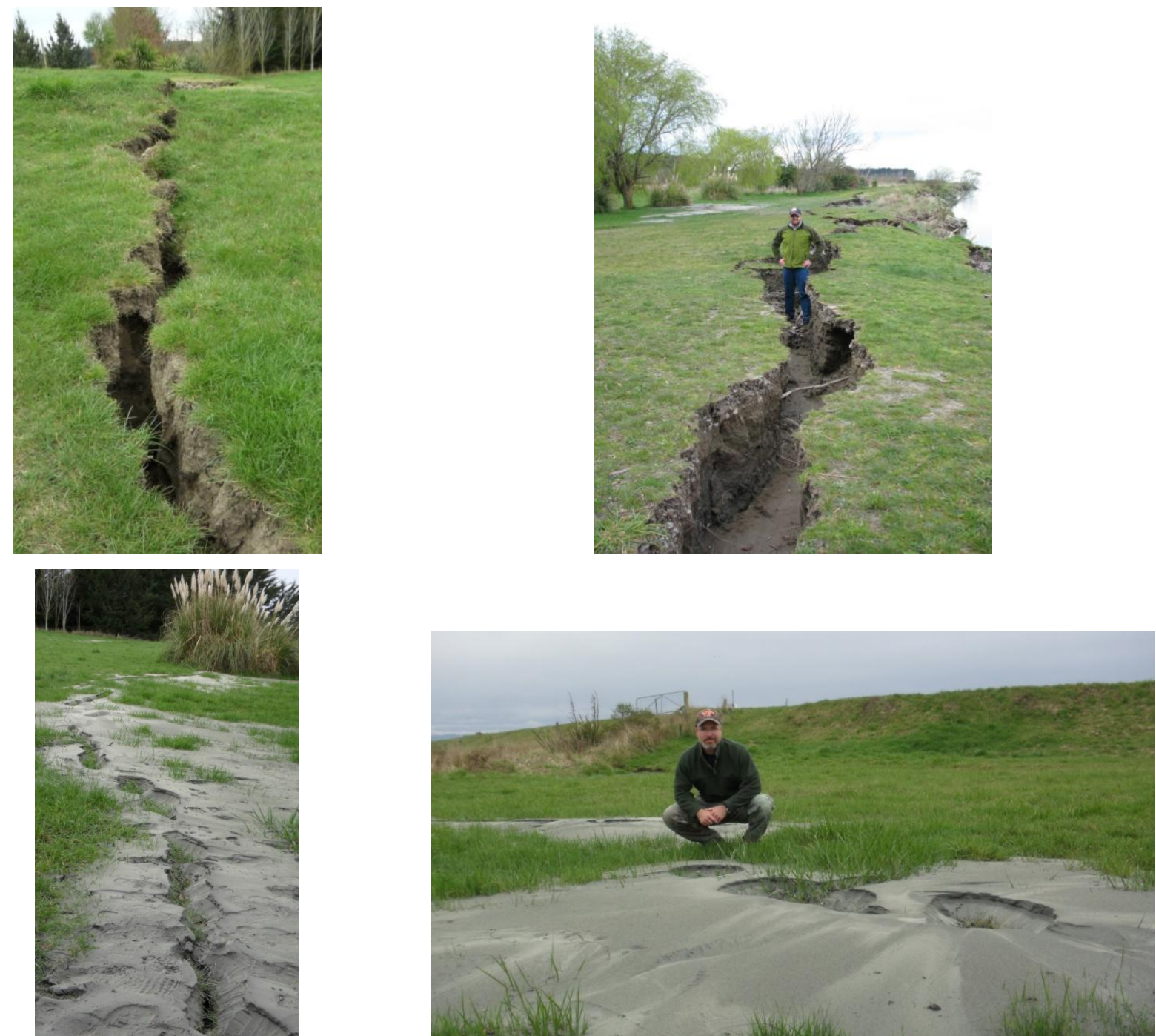

Figure 6.28: Liquefaction and lateral spread features on or near stopbanks located about 100 to $200 \mathrm{~m}$ west of the Kaiapoi Sewage Treatment Plant. (upper left: $43.389175^{\circ} \mathrm{S}, 172.683235^{\circ} \mathrm{E}$; upper right: $43.389701^{\circ} \mathrm{S}, 172.683390^{\circ} \mathrm{E}$; bottom left: $43.389519^{\circ} \mathrm{S}, 172.682203^{\circ} \mathrm{E}$; bottom right: $\left.43.389432^{\circ} \mathrm{S}, 172.6682060^{\circ} \mathrm{E}\right)$.

the southwest corner of the plant (Figure 6.27). Photographs of the liquefaction and lateral spread features at this location are shown in Figure 6.28.

\subsubsection{Bromley Sewage Treatment Plant}

The wastewater treatment plant operated by the Christchurch City Council is situated at Bromley, approximately $6.5 \mathrm{~km}$ east of the Christchurch CBD and southwest of the Bexley subdivision. Here the domestic and industrial wastewater of Christchurch is treated before being discharged to the ocean via an outfall that discharges $3.2 \mathrm{~km}$ off the coastline. The treatment system comprises screening, sedimentation tanks, trickling filters, clarifiers and tertiary treatment within the oxidation pond system before discharge to the outfall. The capacity of the outfall is $5.5 \mathrm{~m}^{3} / \mathrm{s}$ and the treatment plant was operating at around $2 \mathrm{~m}^{3} / \mathrm{s}$ at the time of the earthquake. The oxidation ponds were constructed in the early 1960s and cover an area of around 230 ha (Figure 6.29).

Dyers Road along State Highway 74 cuts through the oxidation ponds and connects the northern approaches to Christchurch with the port of Lyttelton to the south. Road pavements were cracked at the side of the oxidation ponds (between Ponds 2A and 3) and the road was impassable following the earthquake. According to the engineer interviewed at the site, a $500 \mathrm{~mm}$ wide crack had opened near the centreline of the road, although it was already filled with compacted dense graded aggregate during the site visit (Figure 6.30). Nevertheless, longitudinal cracks were still evident on the side of the road (Figure 6.31).

The middle third of the Pond 1/2A embankment sustained the most severe failure throughout the pond system over a length of around $450 \mathrm{~mm}$. At this location there are multiple deep longitudinal cracks along the embankment. The cracks were $1.5 \mathrm{~m}$ deep and up to $700 \mathrm{~mm}$ wide at the top. Many of the cracks were interconnected and some were transverse to the embankment, running from Pond 1 to Pond 2A. There is a $1.22 \mathrm{~m}$ diameter concrete pipeline beneath Pond 1 which can take flow from the treatment plant and bypass it directly to Pond 4. This pipeline "floated" over several hundreds of metres by up to $1.2 \mathrm{~m}$ in elevation, but typically less than 300 $\mathrm{mm}$ (Figure 6.32). During site inspections on Monday 6th and Tuesday 7th September 2010 there were no observations that the pipeline had "floated". Also examination of the Google GeoEye image taken hours after the earthquake showed no trace of this pipe. The pipe was firstly observed to have "floated" on the 9th September 2010 as the pond water level was being lowered as part of the emergency mitigation measures.

The discharge weir structure at the outlet of Pond 2B has three pipes that transfers flow to Pond 3. The pipelines consist of 


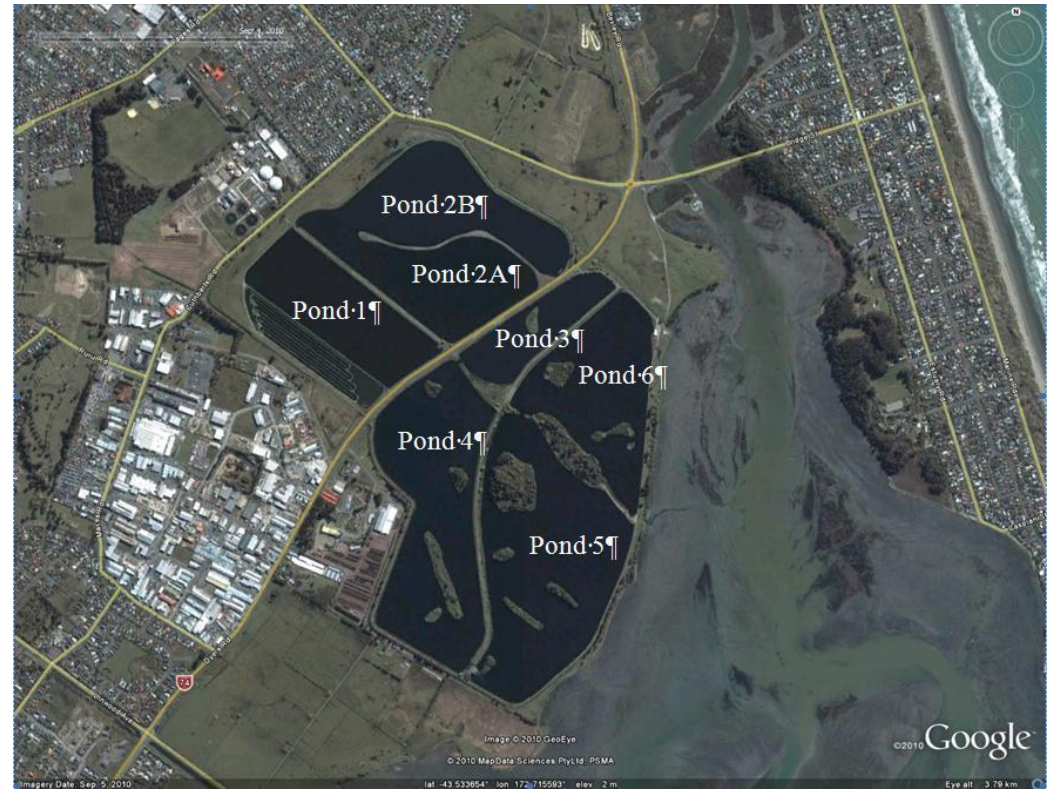

Figure 6.29: Aerial image of the Bromley Sewage Treatment Plant. (-43.535029 $\left.{ }^{\circ}, 172.714052^{\circ}\right)$.

two original pipelines of $900 \mathrm{~mm}$ diameter and a larger more recent pipeline of $1.80 \mathrm{~m}$ diameter.

The weir structure is located out into the pond and allows flow over individual weirs on all four sides. Each of the three pipelines became dislocated in the gap between the structure and the embankment allowing water to flow directly into the pipelines at the gaps formed in the pipe separations. Furthermore, sink-holes were formed on the embankment berms and in the middle of Dyers Road indicating that the pipes had separated beneath the embankment fill (Figure 6.33). The eastern end of Pond $2 \mathrm{~B}$ was cracked and the internal side of the embankment had slumped into Pond 2B by up to $400 \mathrm{~mm}$ at its eastern end. The slumping was also evident along most of the length of the Pond $2 \mathrm{~A} / 2 \mathrm{~B}$ internal baffle which was recently constructed in 2004. Sand boils were also evident along the toe drain which runs along the northern side of Ponds 2B, 3 and 6 (sand boils were rare on top of the embankments).

Extensive cracking was experienced along the majority of the embankment that separates Ponds 3 and 6 . The total length of this embankment is around $600 \mathrm{~m}$ in length and severe to moderate cracking was experienced over a length of about 450 $\mathrm{m}$. Several sets of cracks were noted to exist across the width of the embankment at the worst affected locations. The larger of the cracks were around $400 \mathrm{~mm}$ to $500 \mathrm{~mm}$ in width and around $1.5 \mathrm{~m}$ deep. The base of the crack was not visible due to either pond water or collapse debris blocking its lower extent. A small sinkhole had formed over the outlet pipeline from the northernmost weir structure in Pond 3. As with the pipelines beneath Dyers Road, it would appear that the pipeline was either broken and/or the spigot had been pulled from its collar allowing soils to fall down in to the pipeline.

Numerous small sand boils were encountered across the floor of the estuary adjacent to Pond 6. One of these sand boils was observed to be flowing water 80 hours after the main earthquake. While not directly inspected, when viewed at low tide it appeared that there has been considerable liquefaction along the alignment of the outfall pipeline (commissioned in 2010) which traverses across the estuary to the New Brighton spit. A large volume of ejecta appears to be located near to the main channel in the estuary (location of thinnest cover over the pipeline).

The distortion of the embankments noted above is indicative of bearing failure of the embankment as it has settled and spread into the liquefied sub-soils, with large tension cracks forming through the fill used to form the embankments and pulling apart of concrete pipelines as the fill has spread. Site investigations undertaken indicate that the soils beneath the pond embankments are potentially liquefiable to depths of 10 $\mathrm{m}$ to $15 \mathrm{~m}$.

Because of the slumping of the pond banks, engineers decided to drop the pond water levels and reduce the hydraulic pressures on the embankments. At the time of the reconnaissance team visit, sheet piles were being driven into the Pond 3/6 embankment to stabilize it and arrest further movement (Figure 6.34). Furthermore, the pipelines beneath Dyers Road were being replaced.

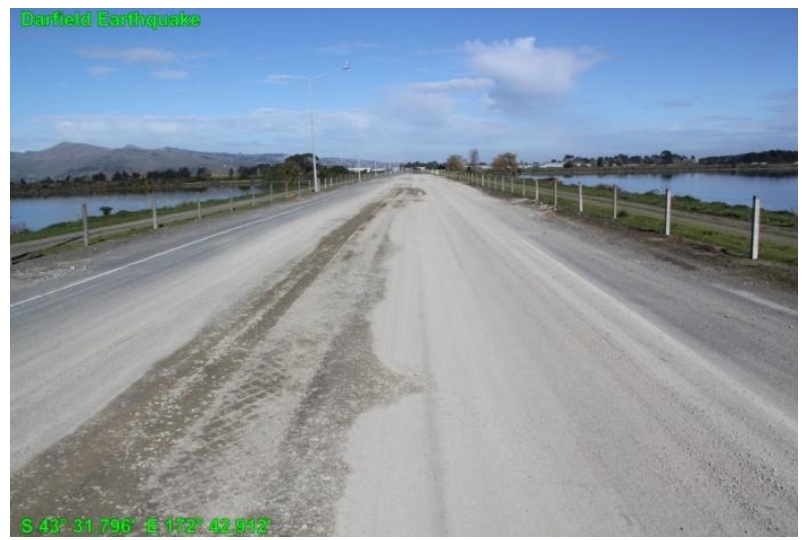

Figure 6.30: $\quad$ Repaired Dyers road that runs between Ponds $2 A$ and 3. $\left(-43.529933^{\circ}, 172.715200^{\circ}\right)$. 


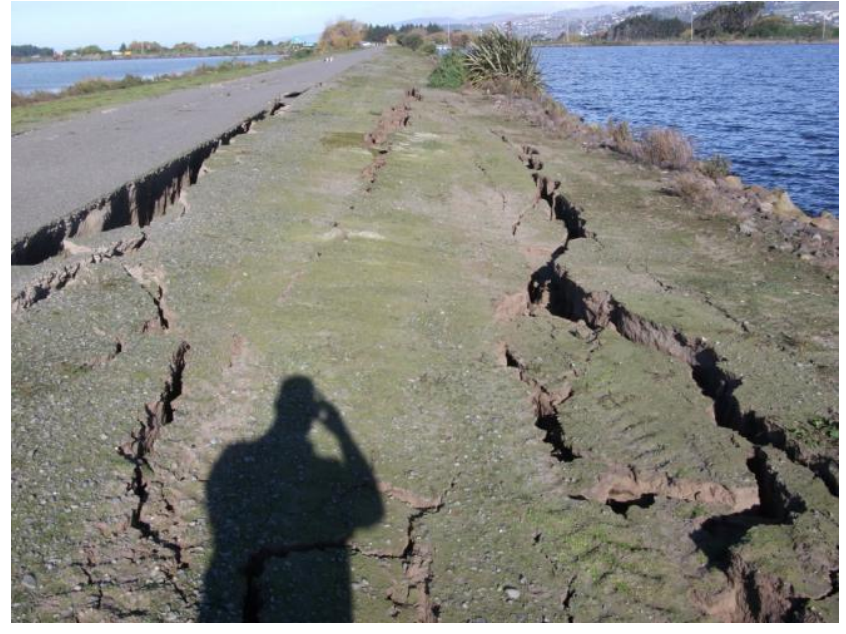

Figure 6.31: Lateral spread cracks running parallel to Dyers Road adjacent to Pond $2 A .\left(-43.531393^{\circ}, 172.712473^{\circ}\right)$.

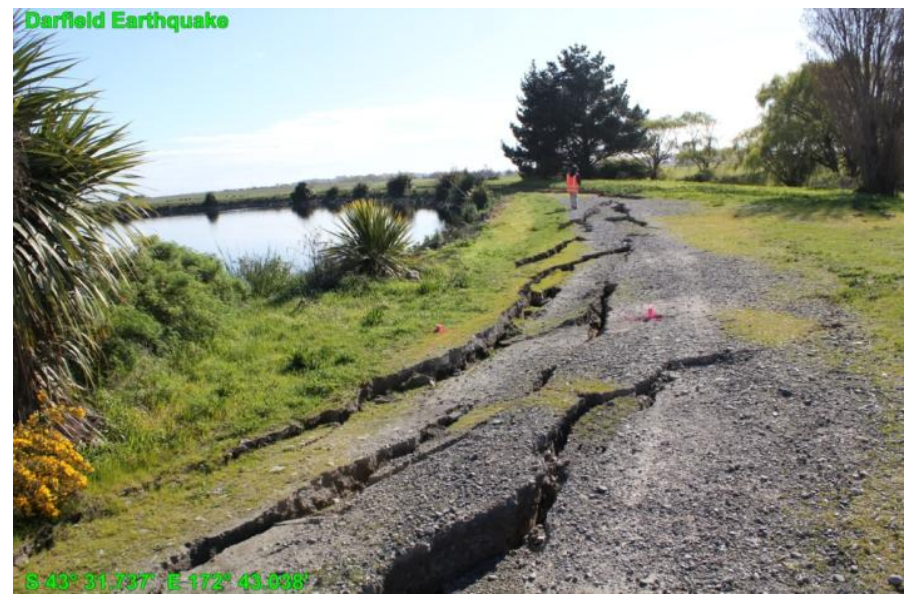

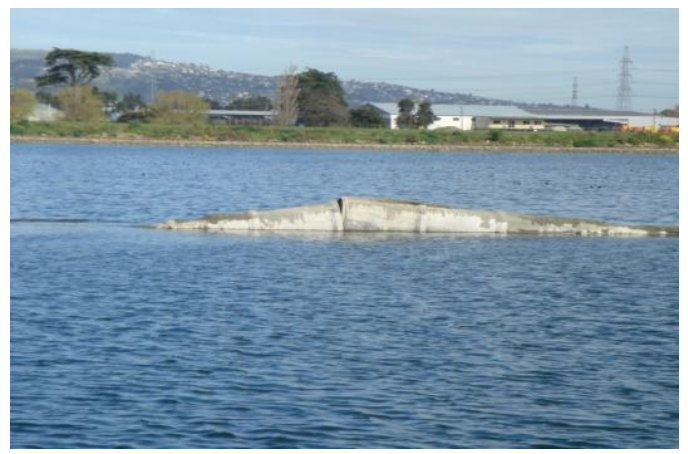

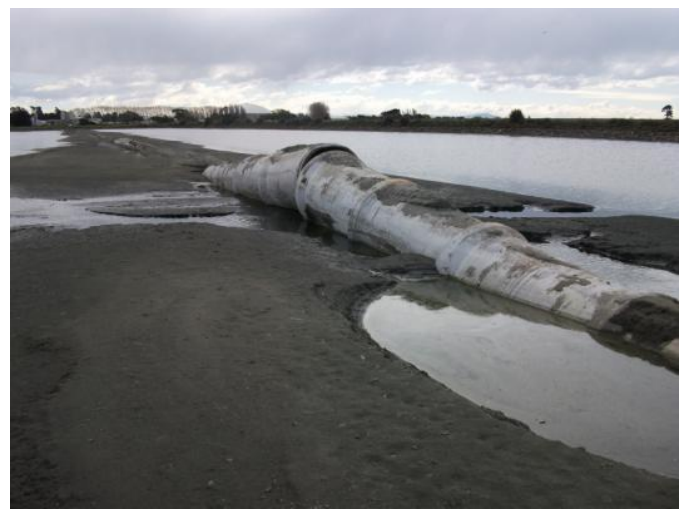

Figure 6.32: Buckled pipe protruding from Pond 1 during pond dewatering, and after pond level was lowered. Pipeline crown was at the pond invert prior to the earthquake. $\left(-43.530867^{\circ}, 172.705190^{\circ}\right)$.

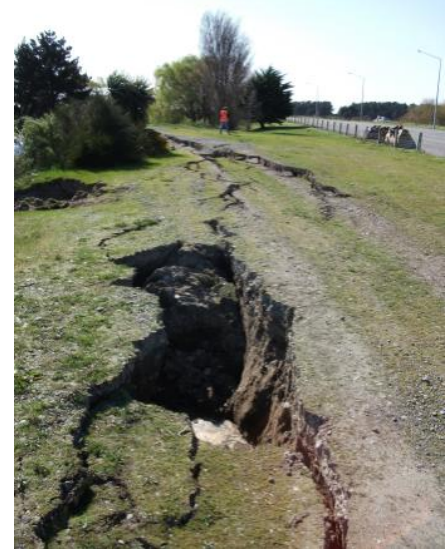

Figure 6.33: Lateral spread cracks at the eastern end of Pond 2B. The sink hole in the foreground of the photo on the right formed over the top of two outlet pipelines. $\left(-43.52895^{\circ}, 172.717300^{\circ}\right)$.
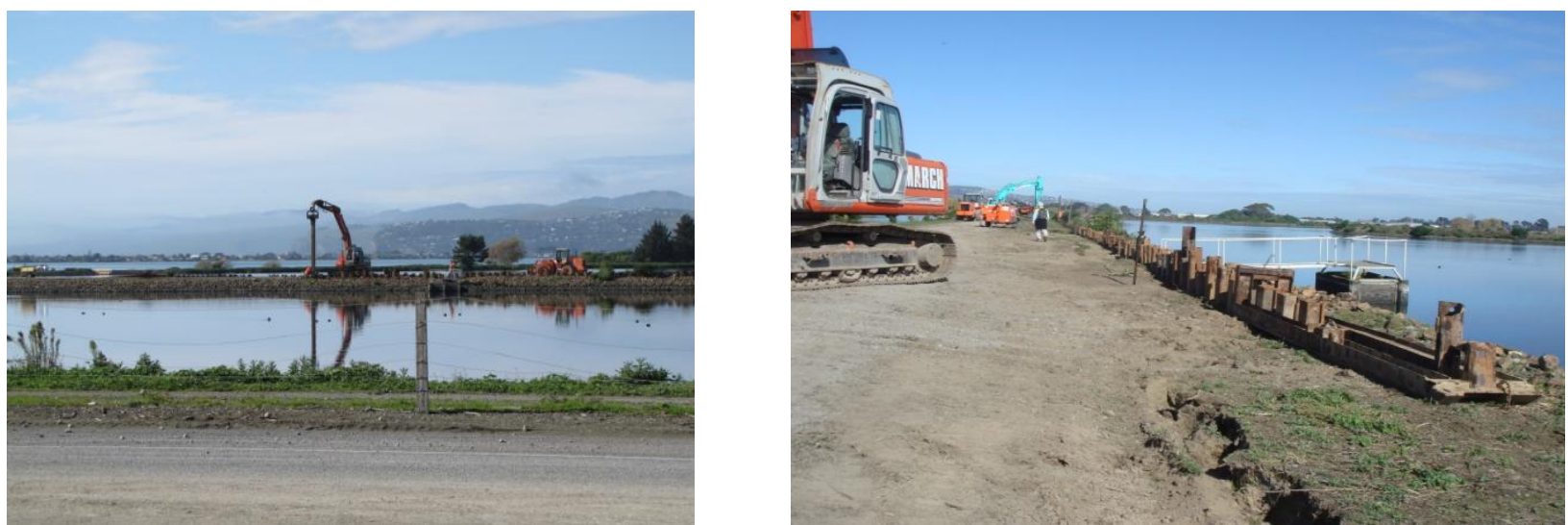

Figure 6.34: $\quad$ Sheetpiles being driven to stabilize the pond embankment to arrest further movement. $\left(-43.530563^{\circ}, 172.718349^{\circ}\right)$. 


\section{EFFECTS ON LIFELINES}

Over the past decade, the people of Canterbury have undertaken a deliberate and dedicated effort to increase the resiliency of the entire lifeline system within the region. And, with the exception of water and waste water distribution lines in the areas affected by liquefaction, lifelines performed quite well. The case for hardening of the lifelines was made in the report "Risks and Realities: A Multi-Disciplinary Approach to the Vulnerability of Lifelines to Natural Hazards" (CAENZ 1997). Following preparation of the report, a plan to enhance the resiliency of lifelines in Canterbury was developed and implemented across all sectors, including transportation, water, waste water, electric power, and communications. In addition, the interdependence of lifelines was recognized and addressed through detailed planning and coordination efforts.

This chapter includes the NZ-GEER Geotechnical Team observations for the transportation system (bridges, highways, rail, airports, and ports), water and wastewater systems, electric power, waste management and landfill, as well as other lifelines.

\subsection{The Transportation System}

While the transportation system did suffer some damage from the earthquake, mobility about the Canterbury region was essentially unaffected with few exceptions.

\subsection{Bridges, abutments, and approach fills}

In general, the performance of bridge foundations, abutments, and approach fills in the earthquake was satisfactory, as almost all bridges were serviceable after the event. According to post earthquake reconnaissance performed by the New Zealand Natural Hazard Platform Bridge Research Group, eight road bridges were out of service in the days following the earthquake, and five remained closed for at least 5 days. One bridge with a ruptured sewer line crossing it (the Kainga Road Bridge in Brooklands) remained out of service for more than 11 days after the earthquake. However, that bridge may have remained closed at the request of local authorities to limit access by outsiders to an area extensively damaged by liquefaction. Except for one bridge with structural damage, these bridge closures were due to damage on the approaches to the bridge, e.g. liquefaction, lateral spreading, and settlement of approach fills. However, none of the road bridges were damaged to the extent that they will need immediate replacement. Six pedestrian bridges were unserviceable after the earthquake and will need to be replaced. While these pedestrian bridges suffered significant structural damage, the primary factor inducing structural distress in most of these cases appears to have been liquefaction-induced lateral spreading at the abutments. In several cases minor leaks in water pipes crossing road bridges were reported. One railway bridge was reported to need repair.

The geotechnical bridge reconnaissance team conducted visual inspections of six road bridges, one railway bridge, and two pedestrian bridges. However, in some cases the inspection was limited to visual observation from a distance. There was no apparent major damage to bridge foundations, although one abutment wall founded on piles appears to have back-rotated slightly. At several of the vehicular bridges, liquefactioninduced lateral spreading was observed in the approach embankments, abutment fills, and in the banks adjacent to the bridge. At road bridge locations where lateral spreading, or incipient lateral spreading, was observed in the abutments, the tendency for the abutments to converge (move inwards towards the centre of the span) appears to have been resisted by the bridge deck, though there was typically signs of lateral spreading of the approach embankments perpendicular to the roadway. Cracking of abutment retaining walls was observed at several of these road bridge locations. At the two pedestrian bridges that the team visited the light deck did not have enough structural strength to resist movement into the channel at the abutments and the bridge decks buckled to accommodate the convergence of the abutments. At the Kainga Road Bridge, the ruptured sewer pipe crossing the bridge continued to discharge untreated sewage into the river for at least 12 days after the earthquake. More detailed descriptions of the NZ-GEER Reconnaissance Team's findings follows.

\subsubsection{South Brighton (Bridge Street) Bridge}

Perhaps the most significant damage at the road bridges observed by the geotechnical bridge reconnaissance team was at the Bridge Street bridge in South Brighton $\left(43.5253^{\circ} \mathrm{S}\right.$, $172.7242^{\circ} \mathrm{E}$ ), an approximately $70 \mathrm{~m}$ span with a centre pier and seat type abutments and a slight skew (less than 30 degrees) spanning the Avon River. The bridge was reportedly closed for approximately 10 days following the earthquake due to differential settlement at the east abutment. When the Team arrived on the 11th day after the earthquake, dense graded aggregate had been placed and compacted on the approach to the east abutment (Figure 7.1) and traffic was moving across the bridge once again. Cracking along the margins of the roadway and incipient lateral spreading perpendicular to the roadway was observed (Figure 7.2). There was also incipient spreading along the river bank on both sides of the east abutment (Figure 7.3). Closure of the gap between the bridge deck and abutment at the seat for the deck (Figure 7.4) as well as displacement on the bearing pads (Figure 7.5) suggests that the abutment moved slightly towards the channel. However, the abutment wall is supported on several rows of 14 inch octagonal precast, pre-stressed concrete piles, including a row of batter piles (piles installed on an angle) with a 3:1 batter (inclination), as observed at the west abutment where the piles are exposed (Figure 7.6). Incipient lateral spreading of the bridge abutment, lateral spreading along the banks of the river (Figure 7.7), and closure of the gap at the bridge seat were also observed at the west abutment. The west abutment also appeared to have back-rotated slightly, possibly due to liquefaction-induced settlement of the approach fill, as evidenced by a gap between the back wall and the end fill (Figure 7.8) and tilting of the approach slab at the wing wall (Figure 7.9). There also appeared to have been some pounding between the south edge of the west end of the bridge deck and the abutment wall (Figure 7.4). The New Zealand Natural Hazard Platform Bridge Research Group has reported a thin horizontal crack just above the water line on the centre pier of this structure. However, both the bridge superstructure and its foundations appeared to be structurally intact and the bridge has been reopened for traffic.

\subsubsection{Christchurch Avon River Bridges (Swanns Road, Gayhurst Road, Pedestrian Bridge)}

Incipient lateral spreading of the bridge approach fills and abutments walls and cracking of abutment walls were observed at bridges across the Avon River in Christchurch at Swanns Road $\left(43.5222^{\circ} \mathrm{S}, 172.6600^{\circ} \mathrm{E}\right)$ and Gayhurst Road $\left(43.5217^{\circ} \mathrm{S}, 172.6728^{\circ} \mathrm{E}\right)$. Both bridges are relative small (approximately $30 \mathrm{~m}$ ) simple spans with integral abutments constructed in 1954. At both locations cracking in the roadway on the approaches to the bridge (Figure 7.10) and at Swanns Road lateral spreading of the approach fill (Figure 7.11), incipient lateral spreading at the abutments (Figures 7.12 and 7.13), and cracking of the abutment and retaining walls (Figure 7.14 and 7.15) was observed. However, both bridges remained serviceable. At the footbridge crossing over the river approximately midway between the Swanns Road and Gayhurst Road bridges, just south of where Medway Road 

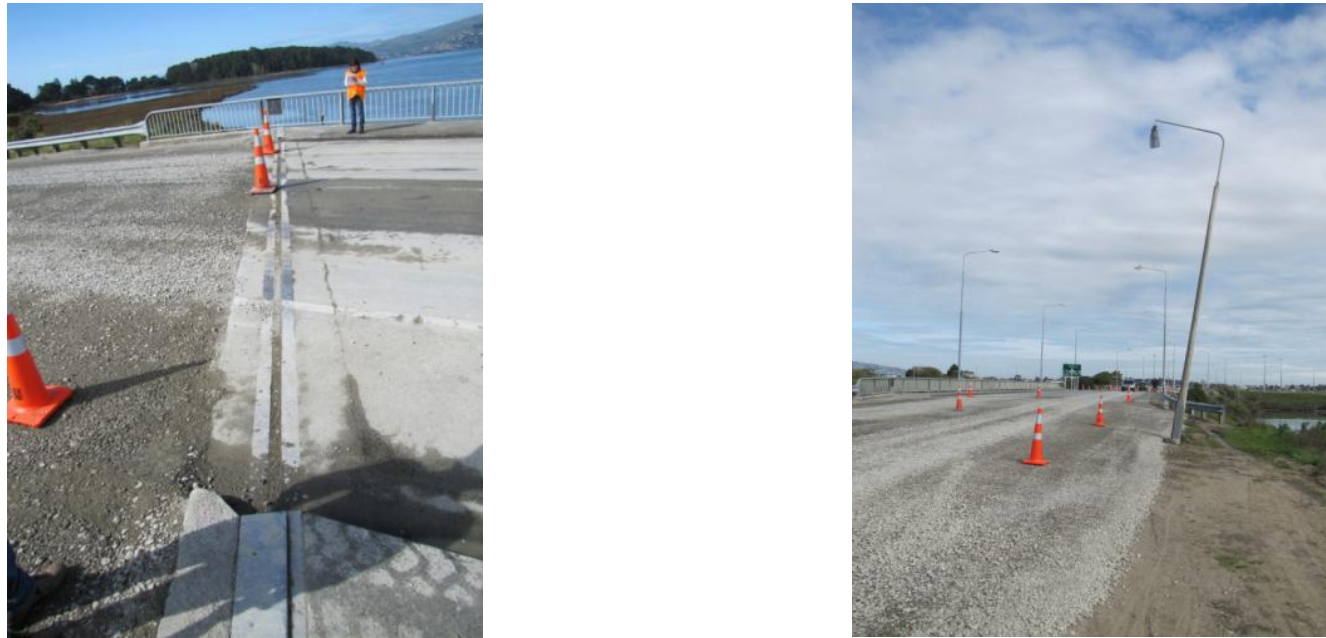

Figure 7.1: $\quad$ Repaired east approach to the Bridge Street Bridge.
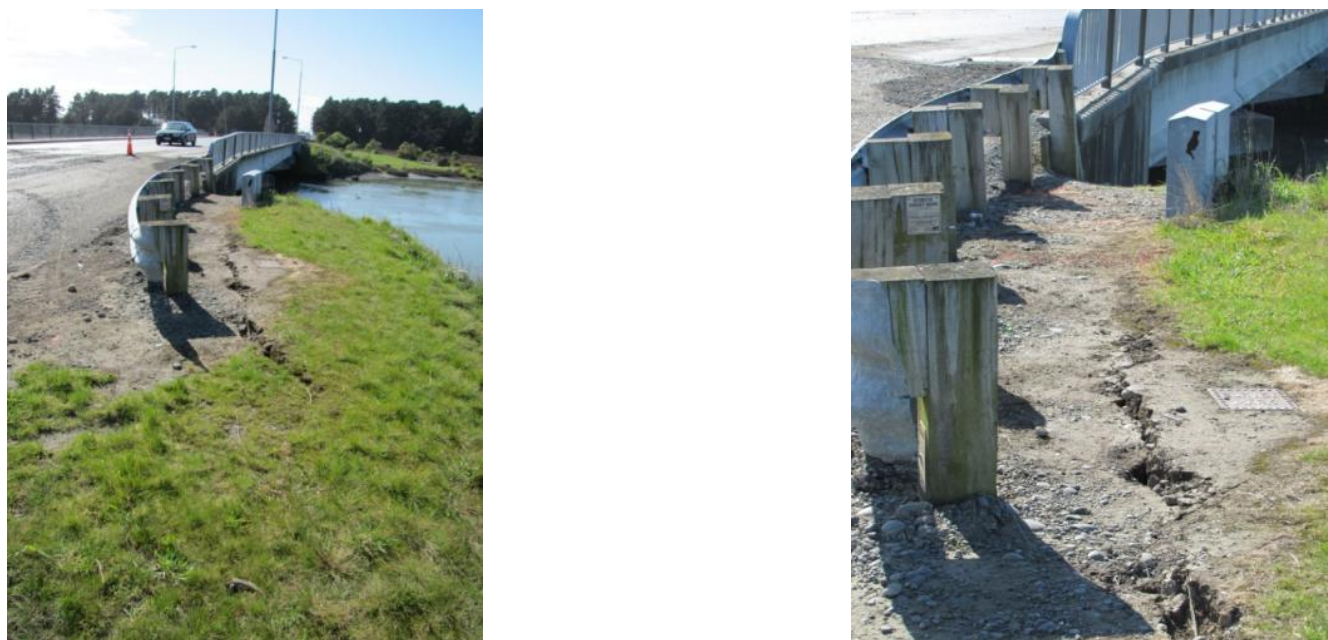

Figure 7.2: $\quad$ Cracking on margins of west approach embankment, Bridge Street Bridge.
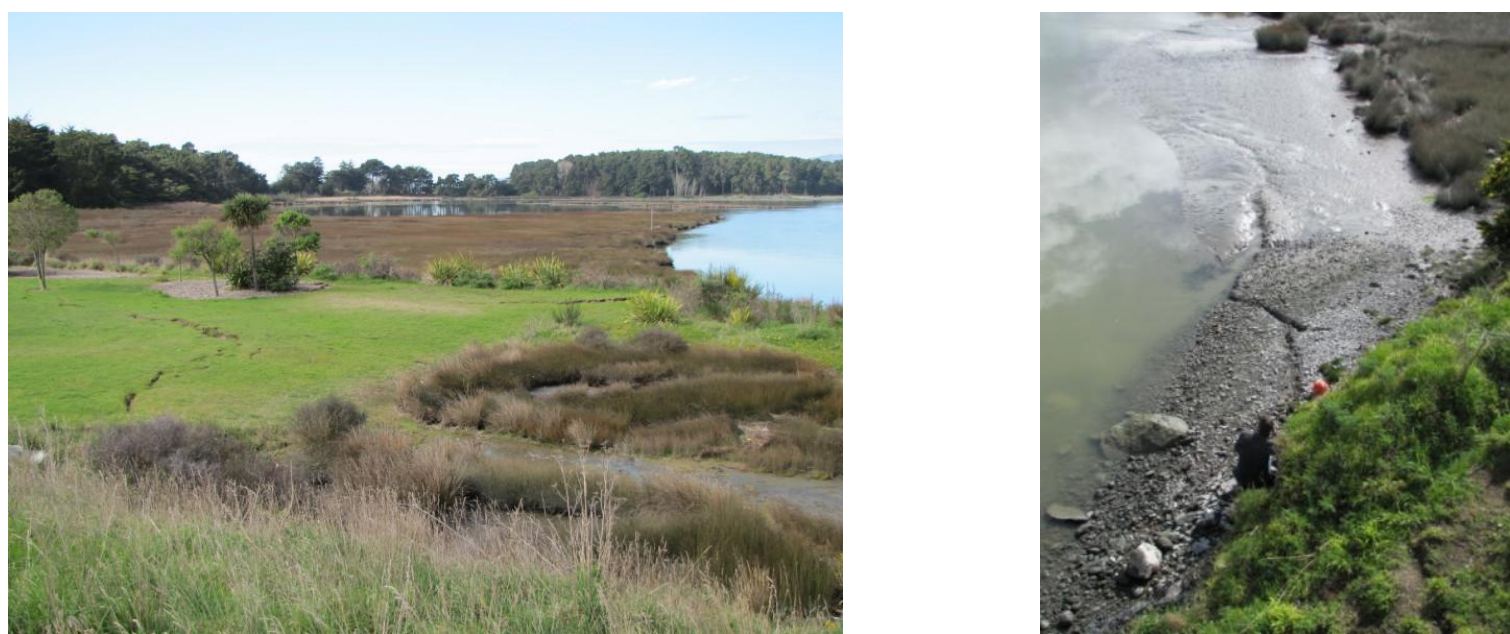

Figure 7.3: $\quad$ Lateral spreading of east banks adjacent to the Bridge Street Bridge.

joins River Road on the west bank of the Avon River $\left(43.531^{\circ} \mathrm{S}, 172.6656^{\circ} \mathrm{E}\right)$, the rather light deck of the bridge buckled to accommodate the lateral spreading at the abutments (Figure 7.16).

\subsubsection{Kaiapoi Bridges (Williams Street, Pedestrian Bridges)}

Behaviour similar to that observed along the Avon River in Christchurch was also observed at Kaiapoi River crossings. Incipient lateral spreading, cracking in the approach roadway, and cracking in the abutment walls was observed at the Williams Street Bridge $\left(43.3825^{\circ} \mathrm{S}, 172.6575^{\circ} \mathrm{E}\right.$ ) (Figures $7.17,7.18$ ) and buckling of the lightweight deck of a pedestrian bridge due to convergence of abutments as a result of lateral spreading was observed just north of Williams Street, in the vicinity of Trousselot Park $\left(43.3811^{\circ} \mathrm{S}\right.$, $172.6558^{\circ} \mathrm{E}$ ) (Figure 7.19). Evidence of liquefaction and incipient lateral spreading was also observed along the walking path from the Williams Street Bridge to Trousselot Park and in the park itself (Figure 7.20). 


\subsubsection{Waimakariri River Bridges (Chaneys Overpass, Highway 1 River Crossings)}

Cracking and incipient lateral spreading was observed at the northern transition between the approach embankment and the abutment at Chaneys overpass (Figure 7.21), where State Highway 1 crosses over the Christchurch Northern Motorway $\left(43.4300^{\circ} \mathrm{S}, 172.6464^{\circ} \mathrm{E}\right)$. The bridge is a three span bridge of about $80 \mathrm{~m}$ with what appeared to be seat-type abutments retrofit with cable restrainers (Figure 7.22). However, outside of a few ruptured precast concrete tiles that covered the end embankment for the north abutment (Figure 7.23), there was no apparent damage to the bridge structure or its foundation, despite ample evidence of liquefaction beneath the bridge (Figure 7.24). The overpass is located in a low lying area that appears to be the flood plain of the Waimakariri River that was subject to extensive liquefaction (Figure 7.25). Cracking was observed in and adjacent to the roadway in the vicinity of the overpass (Figure 7.26) and road crews were busy regrading and paving the approach to the roadway that passed under the overpass (Figure 7.27). This work was undertaken to repair the liquefaction damage to the on-ramp to the motorway.

The NZ-GEER reconnaissance team also inspected the two main spans for the Highway 1 crossing of the Waimakariri River $\left(43.4153^{\circ} \mathrm{S}, 172.6467^{\circ} \mathrm{E}\right)$ (Figure 7.28 ) and the adjacent railroad bridge $\left(43.4128^{\circ} \mathrm{S}, 172.6508^{\circ} \mathrm{E}\right)$. While there was some evidence of liquefaction adjacent to several of the piers for the east span of the Highway 1 crossing (Figure 7.29), there was no indication of displacement of the foundation piers or structural damage to the bridge.

\subsubsection{Kainga Road Bridge to Brooklands Residential Community}

The Kainga Road Bridge is a short span bridge leading to the Brooklands residential community (Figure 7.30), and according to the New Zealand Natural Hazard Platform Bridge Research Group, the bridge remained closed at the time of the Team's visit on 13 September 2010 at the request of local authorities to limit access to an adjacent area extensively damaged by liquefaction. Structurally, the 1963 mixed girderslab reinforced concrete bridge was in good condition. However, movement of the northeast abutment wing wall resulted in damage to an $180 \mathrm{~mm}$ diameter sewage pipe that was rigidly connected along the bridge span (Figure 7.31). Raw sewage continued to flow into the river from the damaged pipe at the time of the site visit (Figure 7.32a). Posted signs and discussions with locals confirmed that the flow was contaminated liquid (Figure 7.32b). Directly below the bridge, a pipe of similar diameter suffered no damage, and the team noted that its support to the abutment wall was filled with flexible foam (Figure 7.33). At the East abutment, the northern wing wall moved towards the river and developed a gap with its backfill soils of about $2 \mathrm{~cm}$, whereas the southern wing wall appeared to remain fixed. Soil spread away from the east abutment south wing wall leaving a gap of about $40-60$ $\mathrm{mm}$ at its toe. Surrounding low lying marshlands and old paddock fields (as indicated by a postal worker interviewed during our visit) showed evidence of liquefaction (Figure 7.34).

The fills at the east and west approaches to the bridge appeared to have settled, but were repaired prior to the Teams visit. This road is one of the three access routes into the communities of Brooklands and Spencerville, the other being Lower Styx Road and Spencerville Rd. Extensive liquefaction was observed in Brooklands, including uplifting of sewer manholes along approximately $2 \mathrm{~km}$ of Lower Styx Road.

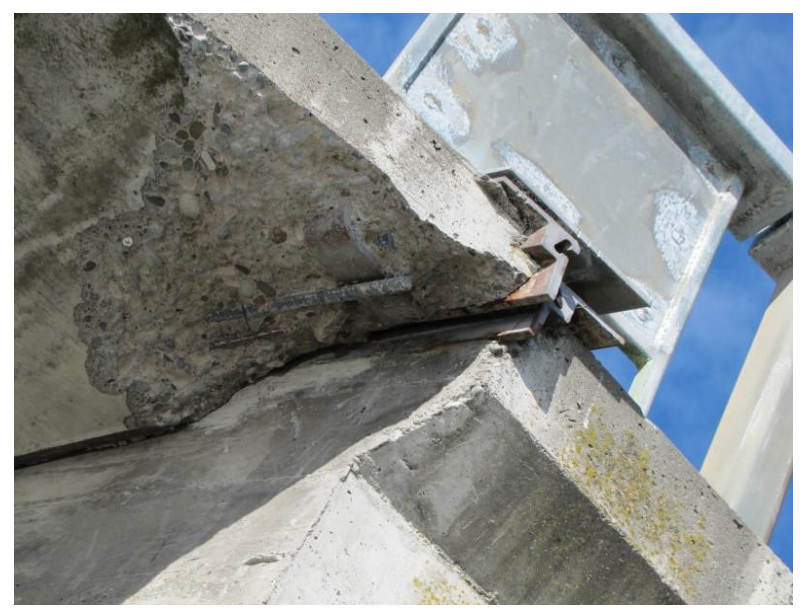

(a) West abutment gap closure and spalling.

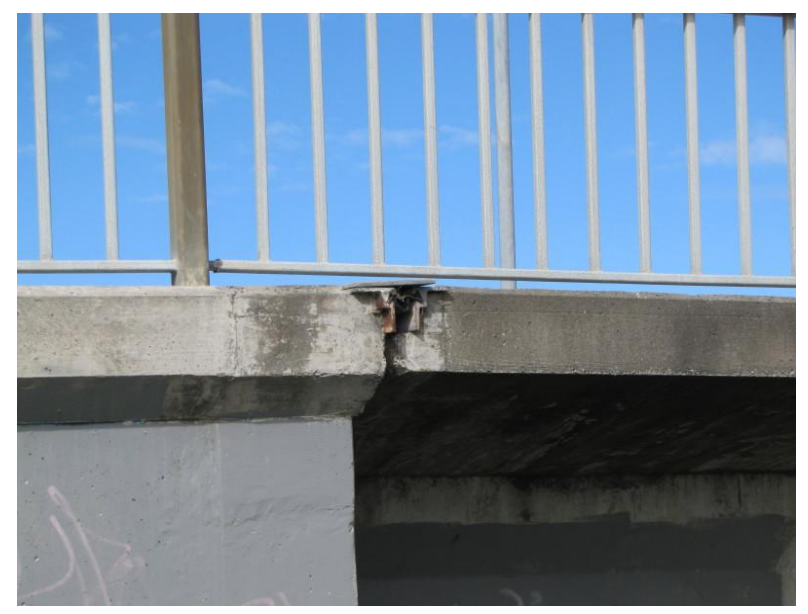

(b) East abutment gap closure.

Figure 7.4: $\quad$ Bridge Street Bridge expansion gap closure.

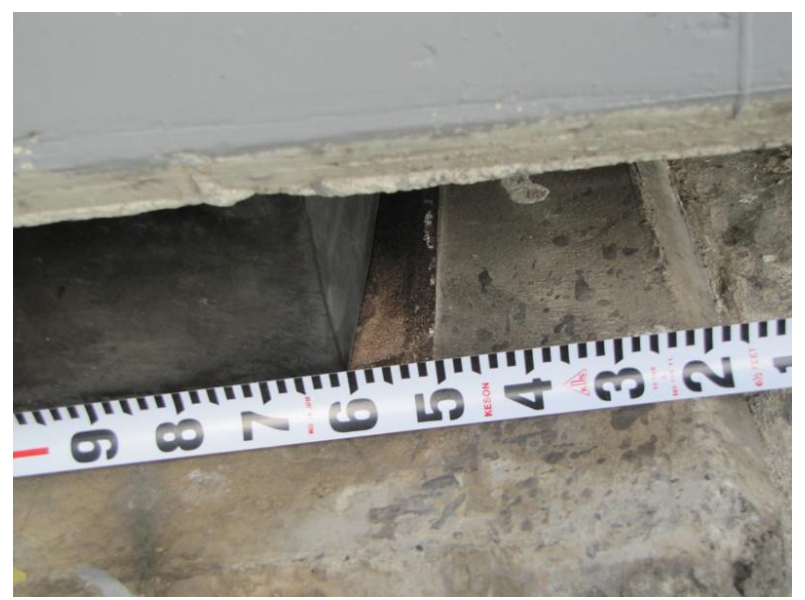

Figure 7.5; West abutment bearing pad displacement, Bridge Street Bridge (scale in Inches). 


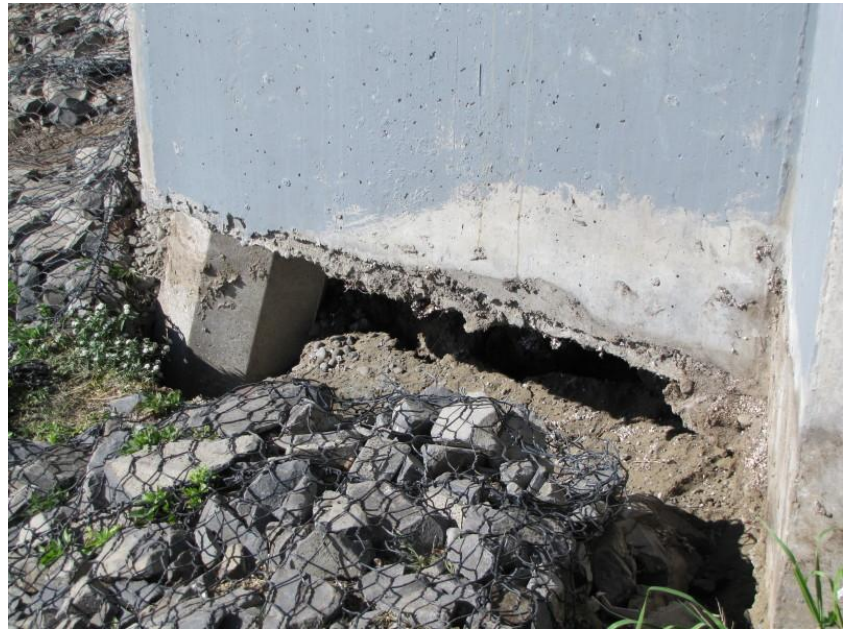

Figure 7.6: $\quad$ West abutment batter (angled) pile, Bridge Street Bridge.

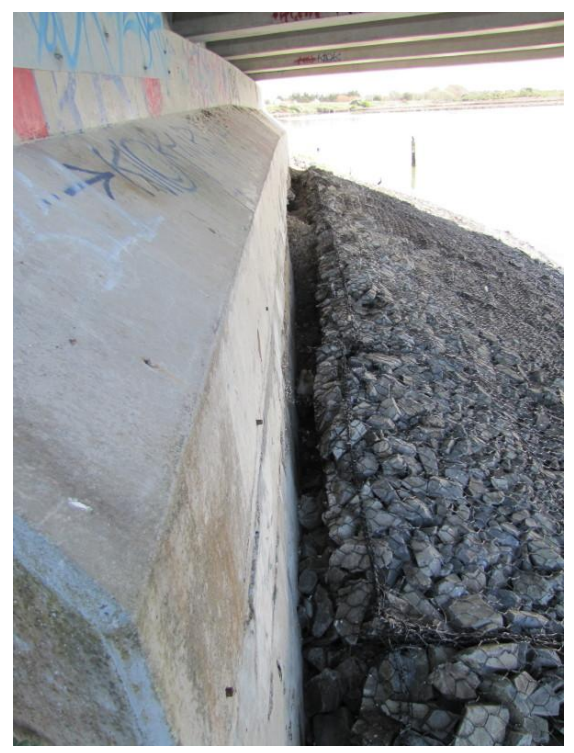

Figure 7.8: $\quad$ Gap between west abutment backwall and end embankment, Bridge Street Bridge.

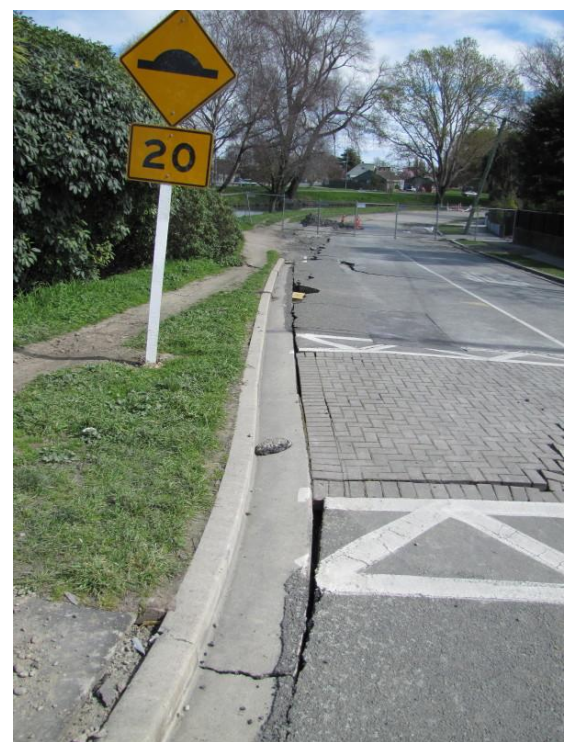

Figure 7.10: Cracking of roadway on west approach fill, Swanns Road Bridge.

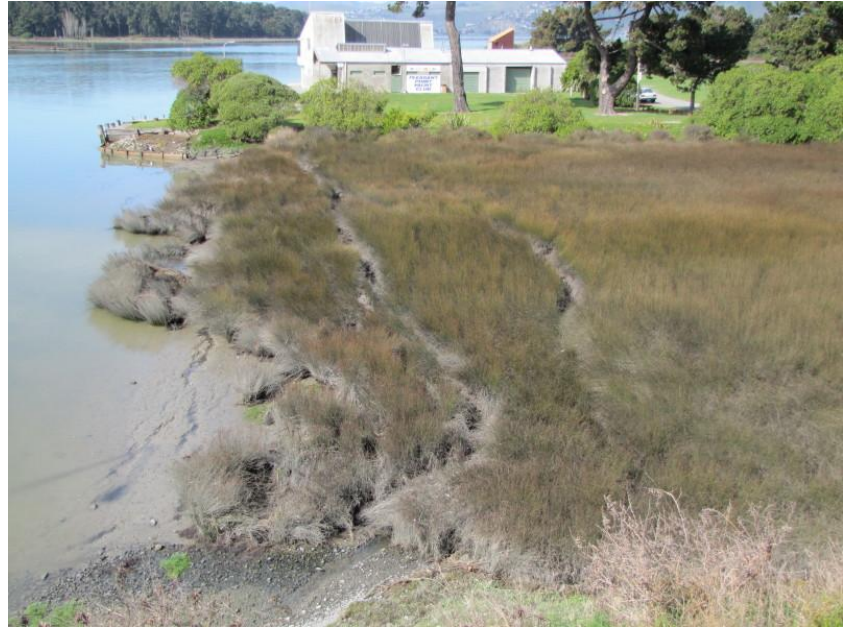

Figure 7.7: Lateral spreading on west bank, Bridge Street Bridge.

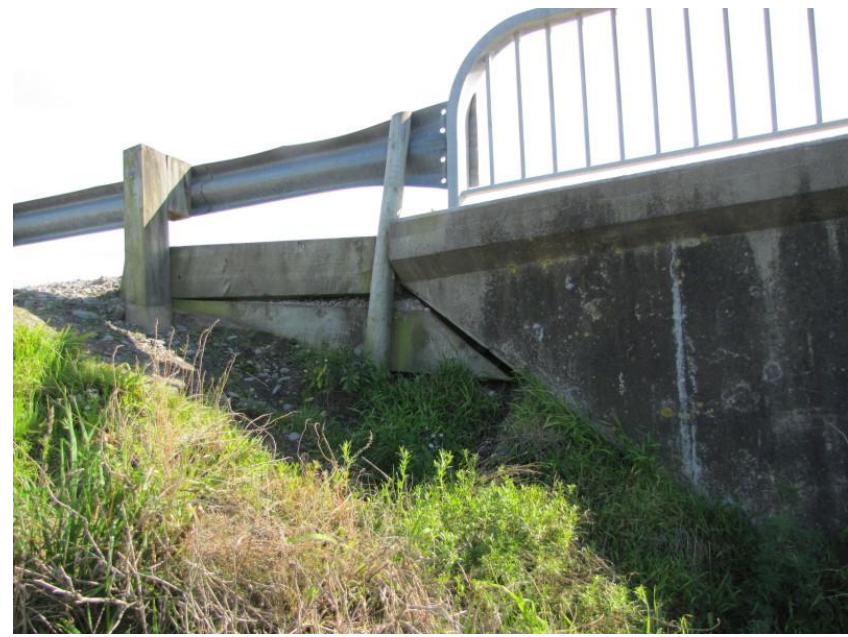

Figure 7.9: $\quad$ Back rotation of west abutment, Bridge Street Bridge.

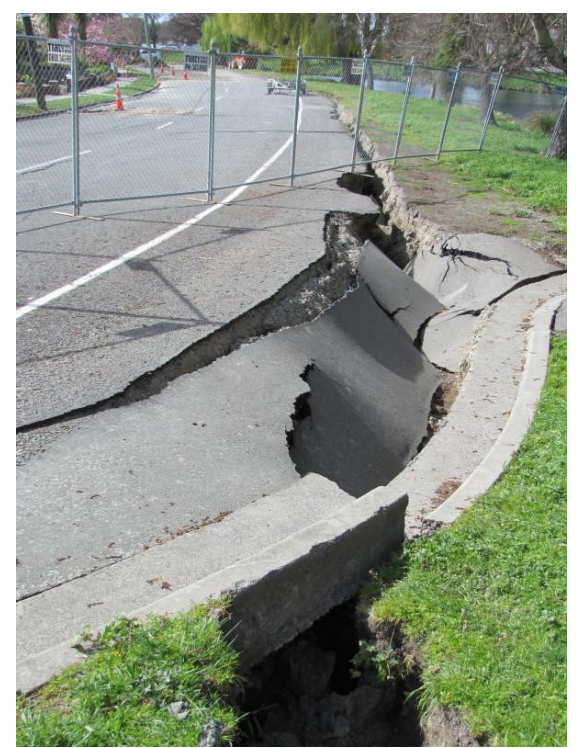

Figure 7.11: Lateral spreading on west approach fill, Swanns Road Bridge. 


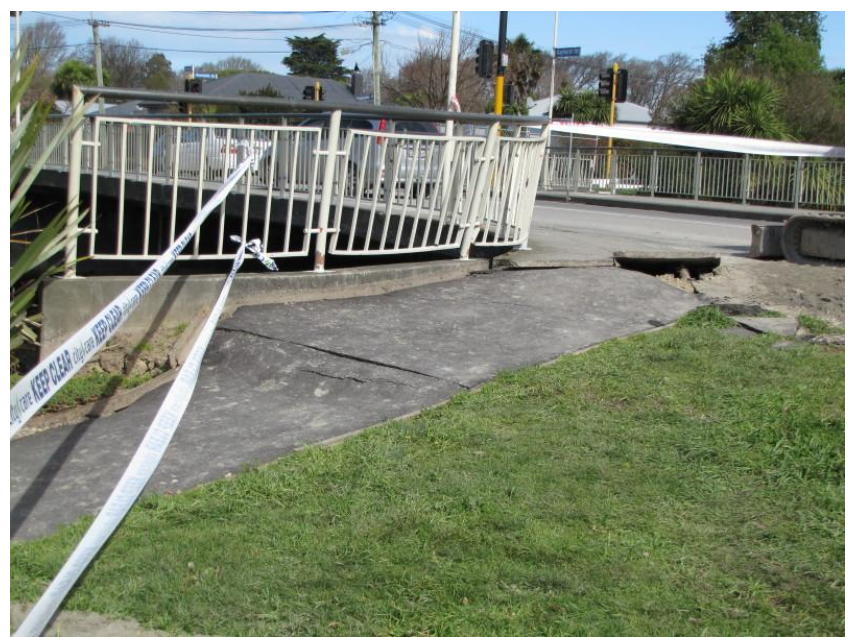

Figure 7.12: Incipient lateral spreading at west abutment, Swanns Road Bridge.

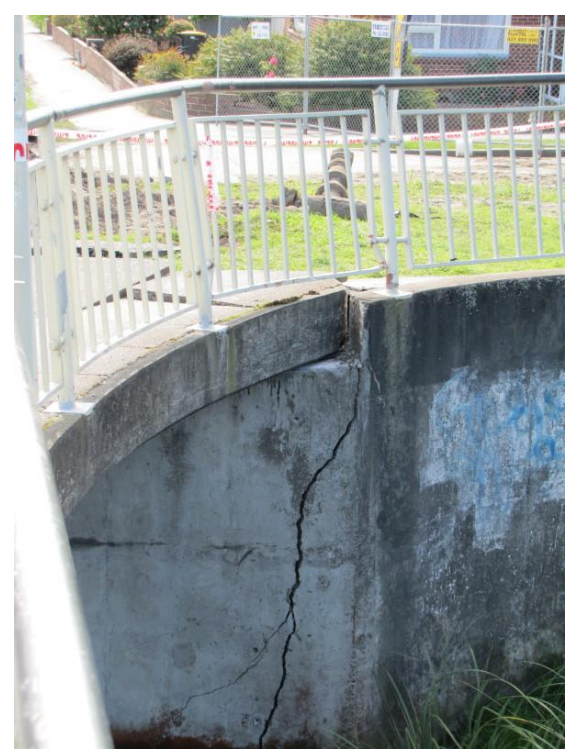

Figure 7.14: Cracking of north abutment, Swanns Road Bridge.

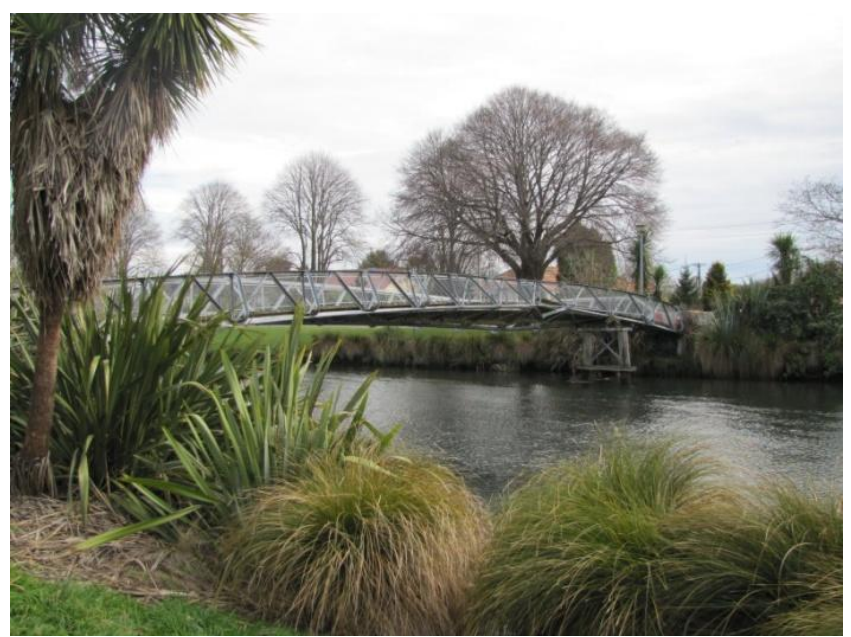

(a) Buckled span.

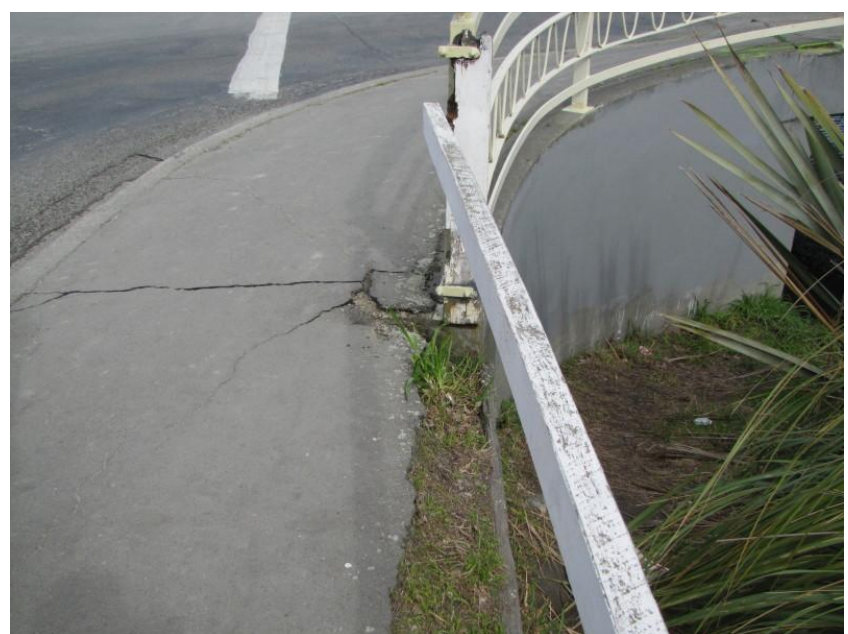

Figure 7.13: Incipient lateral spreading at north abutment, Gayhurst Road Bridge.

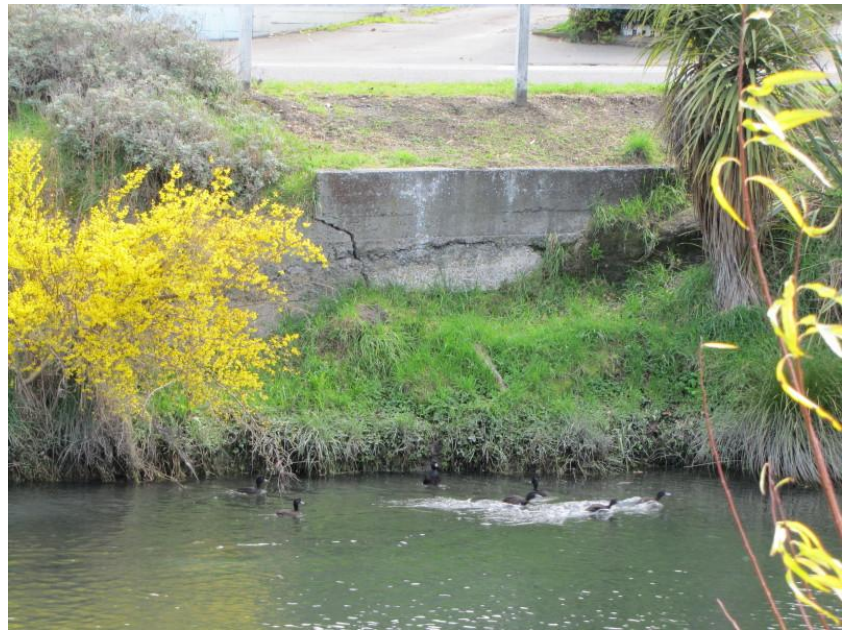

Figure 7.15: Cracking of retaining wall, north bank of the Avon River.

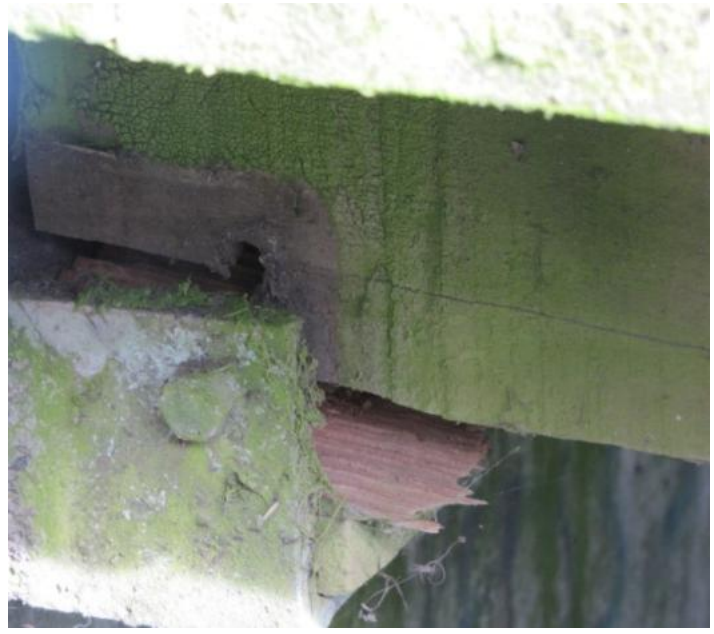

(b) Sheared bearing on east bank.

Figure 7.16: Footbridge on the Avon River near Medway Road. 


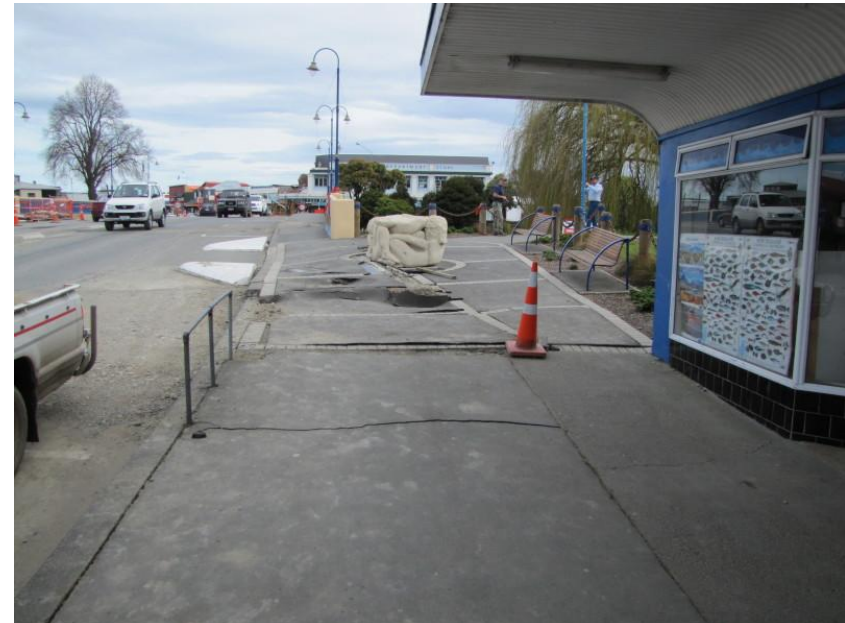

Figure 7.17: Cracking of east approach roadway, Williams Road Bridge.

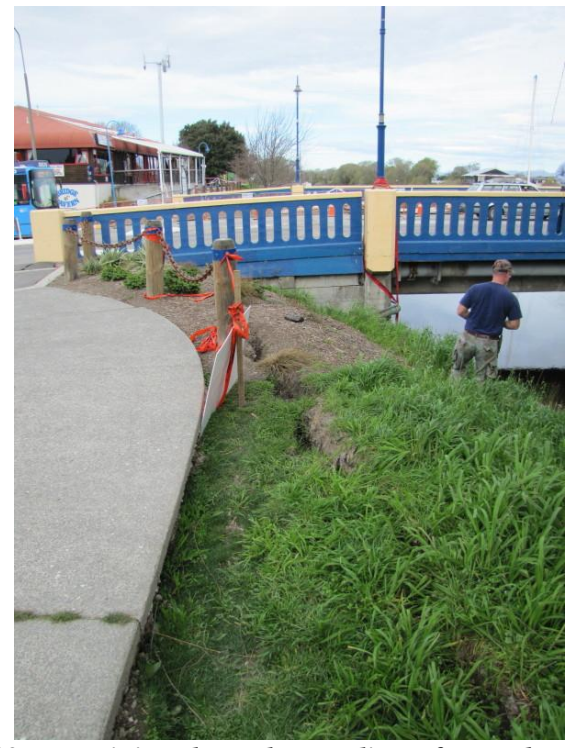

Figure 7.18: Incipient lateral spreading of east abutment, Williams Road Bridge.
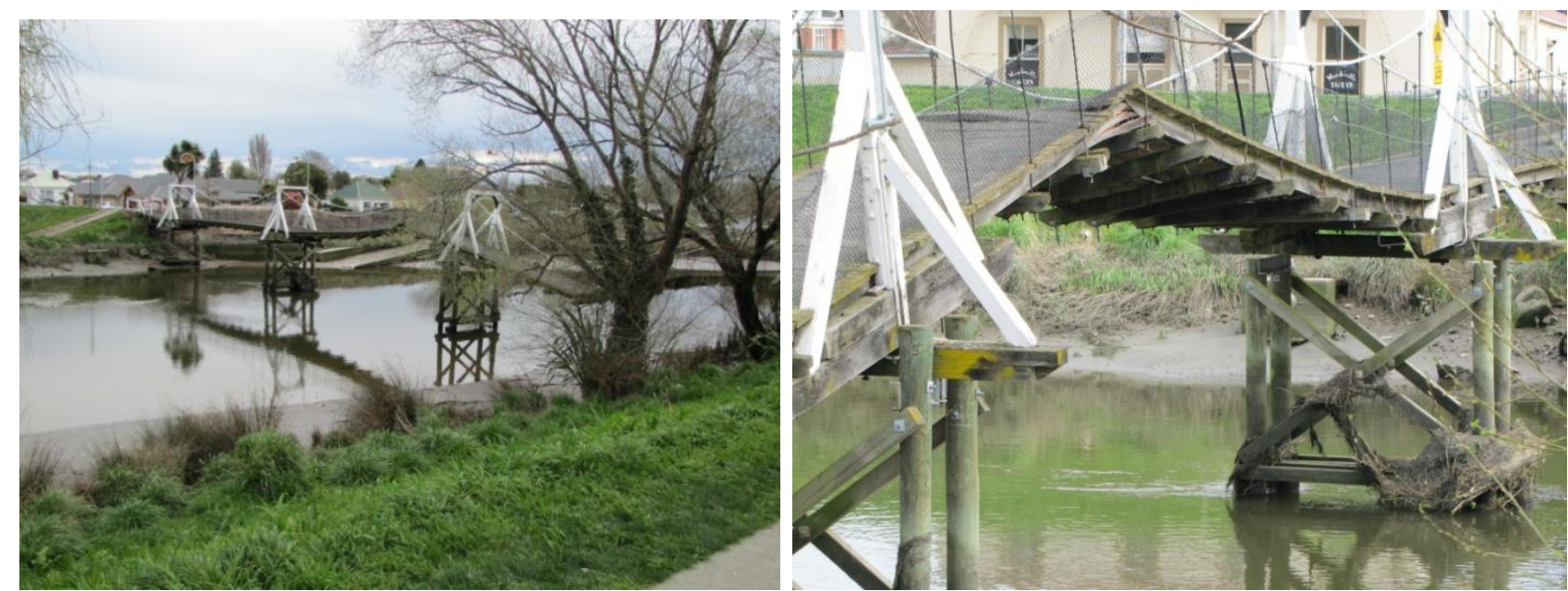

Figure 7.19: Buckling of footbridge near Trousselot Park.

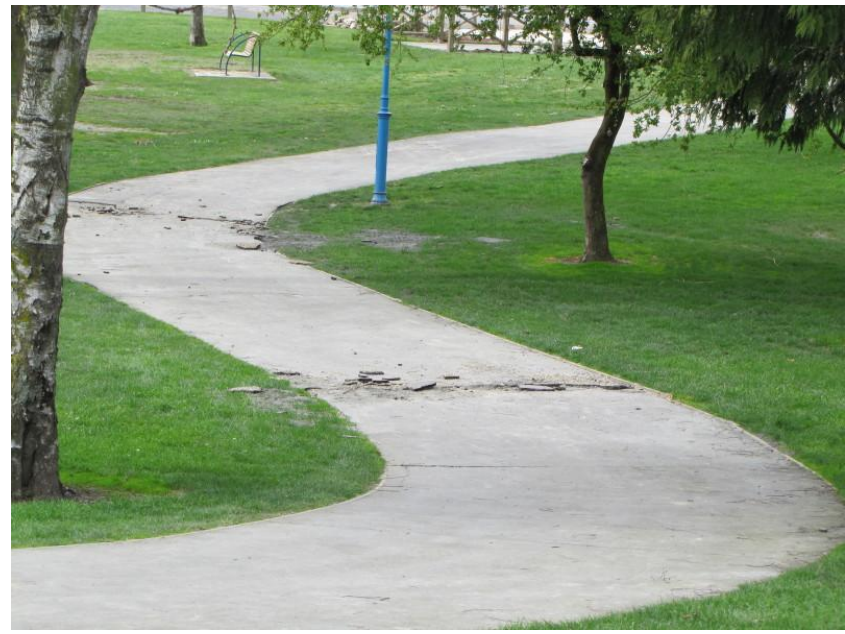

Figure 7.20: $\begin{aligned} & \text { Cracking of sidewalk } \\ & \text { in Trousselot Park. }\end{aligned}$

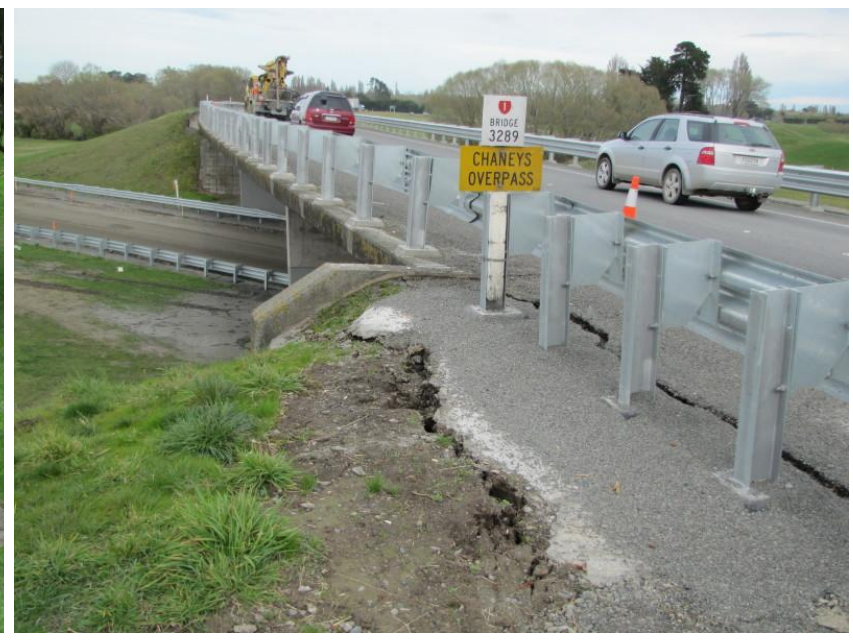

Incipient lateral spreading at Chaneys Overpass north abutment. 


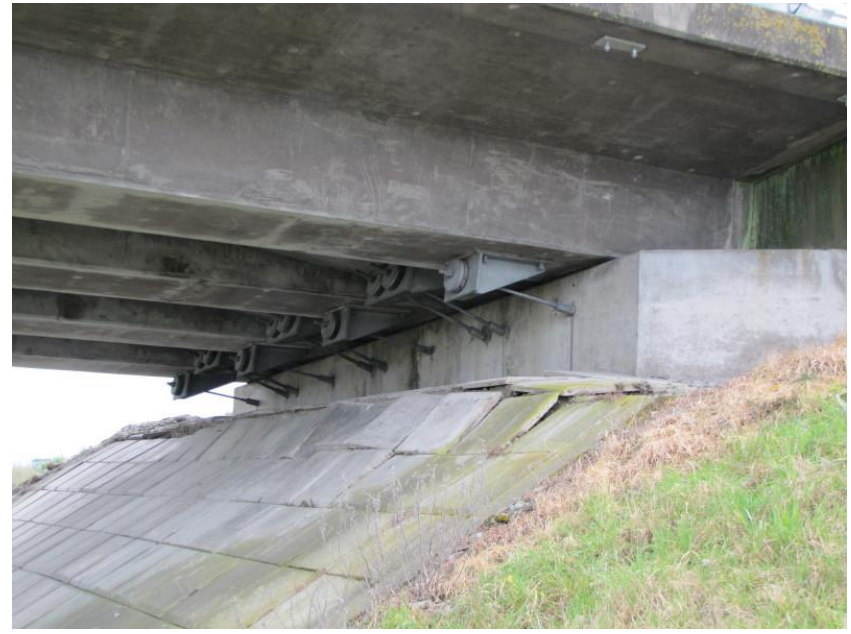

Figure 7.22: Cable Restrainers at north abutment, Chaneys Overpass.

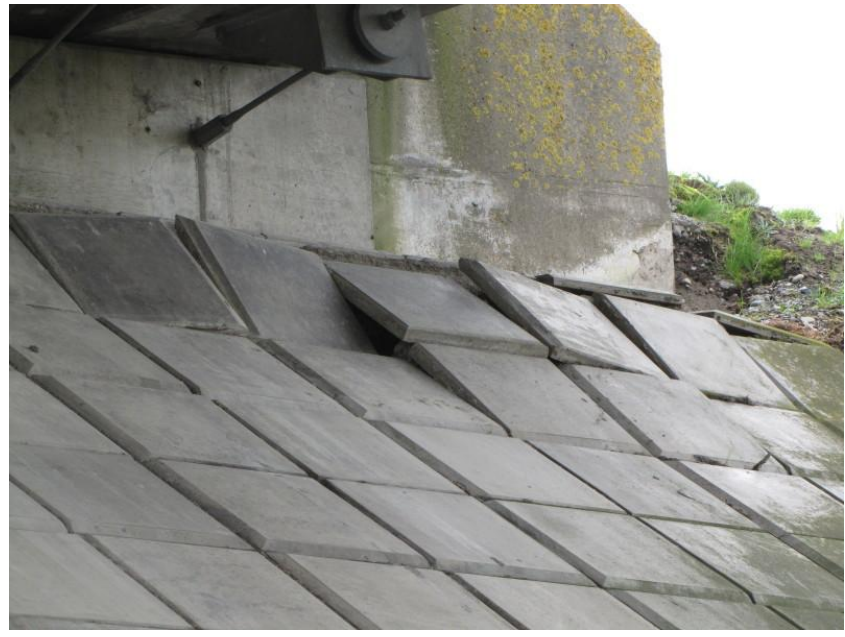

Figure 7.23: Displaced concrete tiles on end embankment for north abutment, Chaneys Overpass.

Figure 7.24: Evidence of liquefaction beneath Chaneys Overpass.
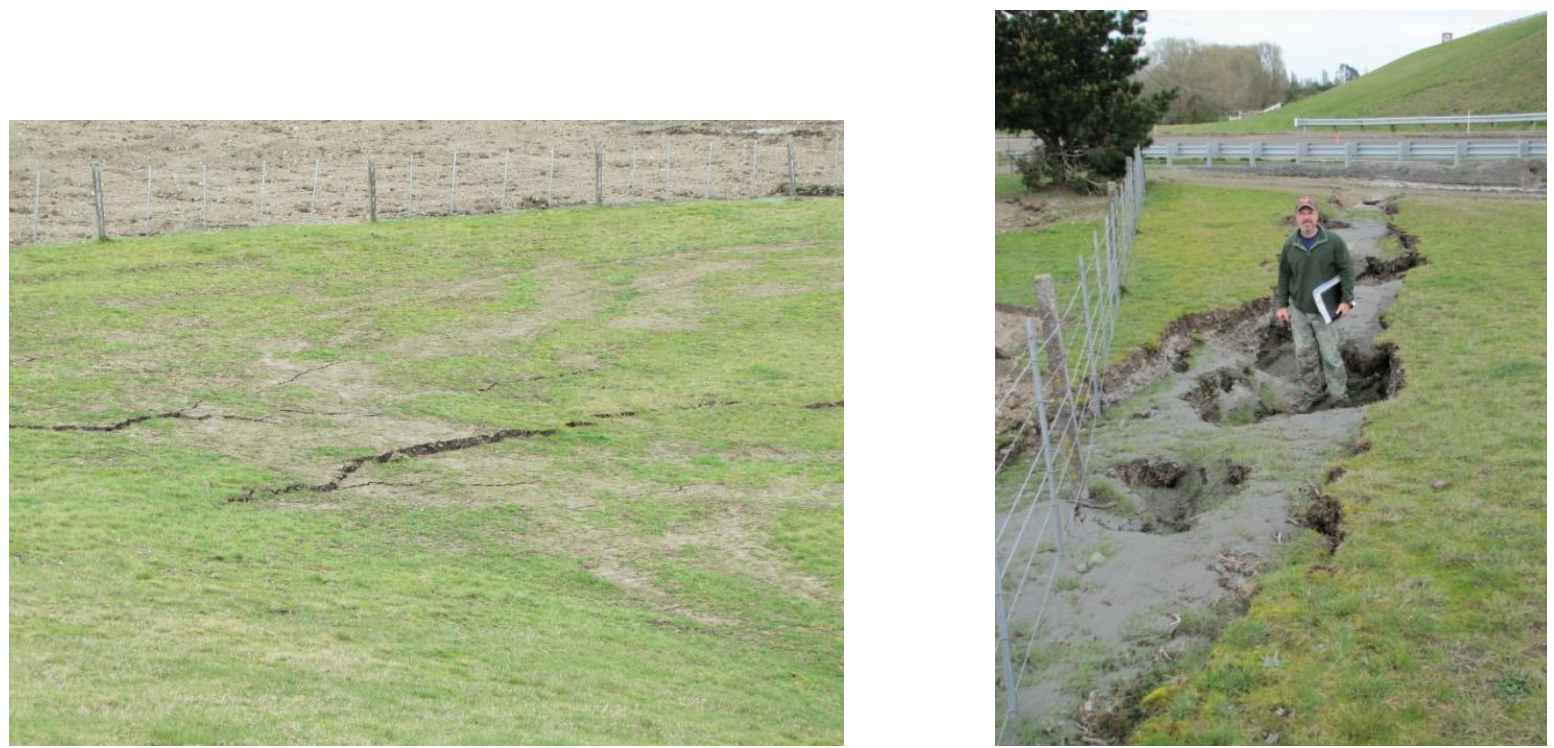

Figure 7.25: Evidence of liquefaction adjacent to Chaneys Overpass. 


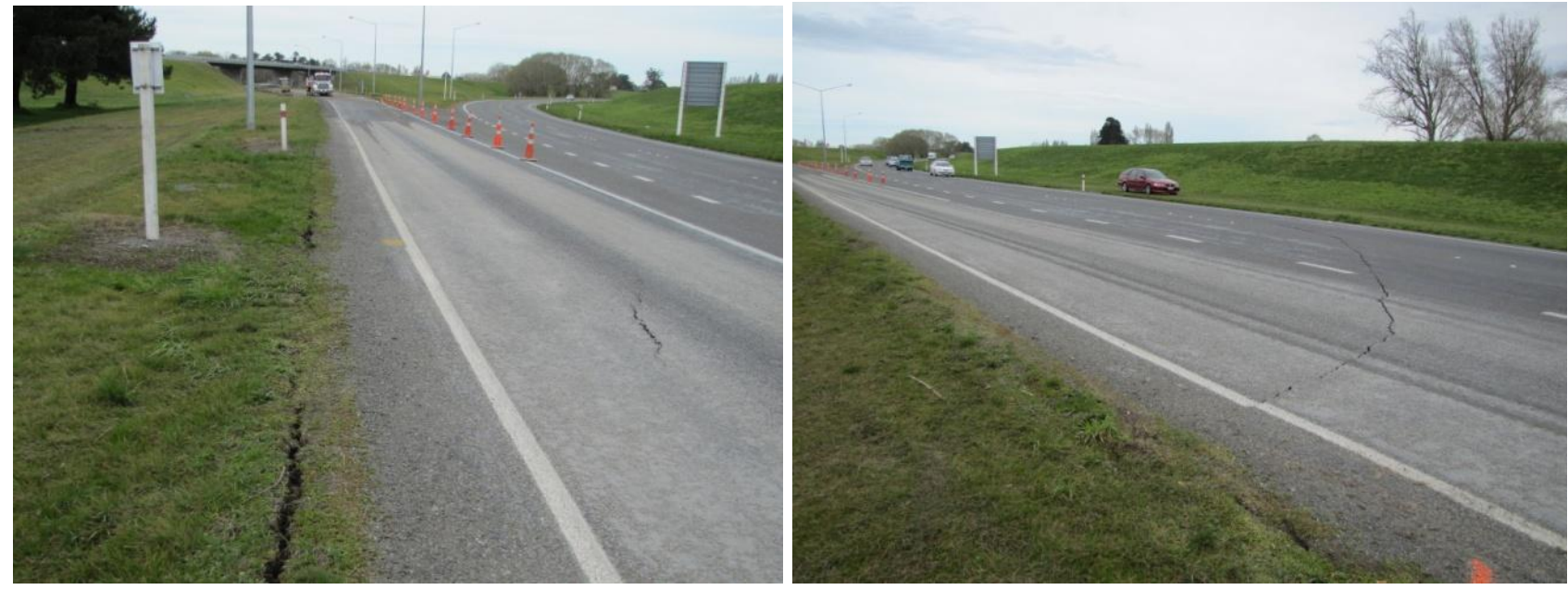

Figure 7.26: Cracking in and along roadway adjacent to Chaneys Overpass.
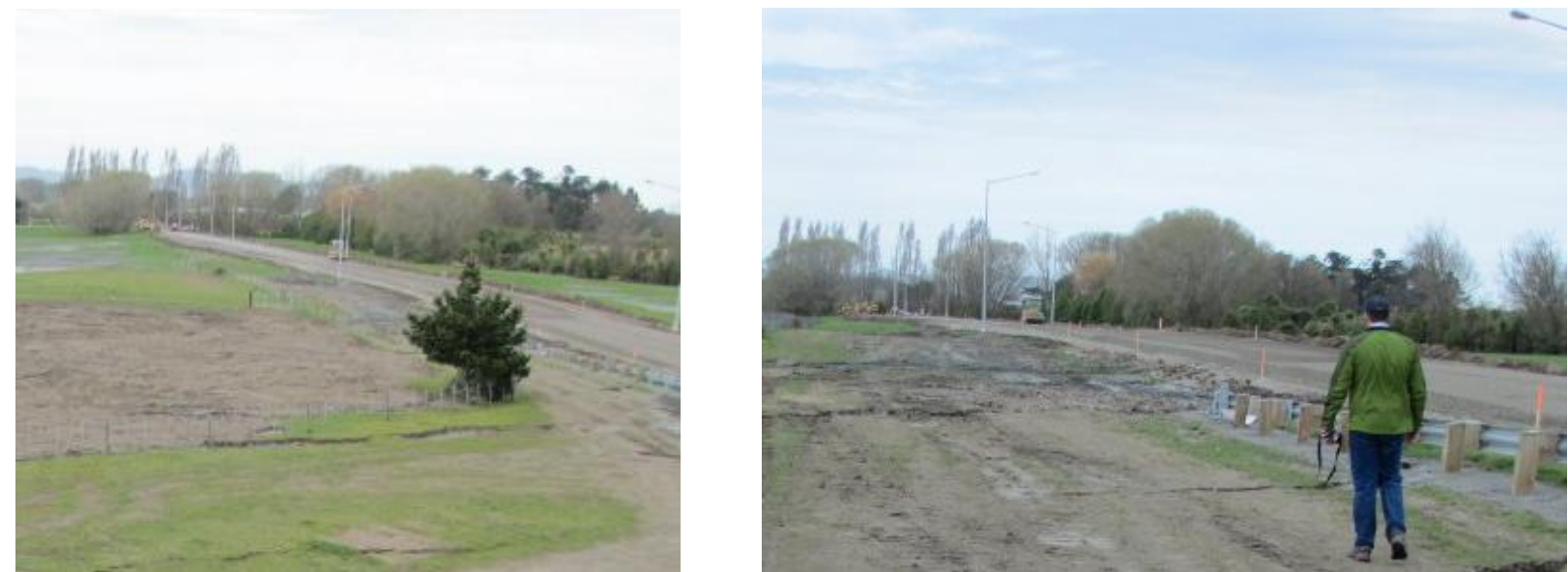

Figure 7.27: Road being repaved adjacent on south approach to Chaneys Overpass.
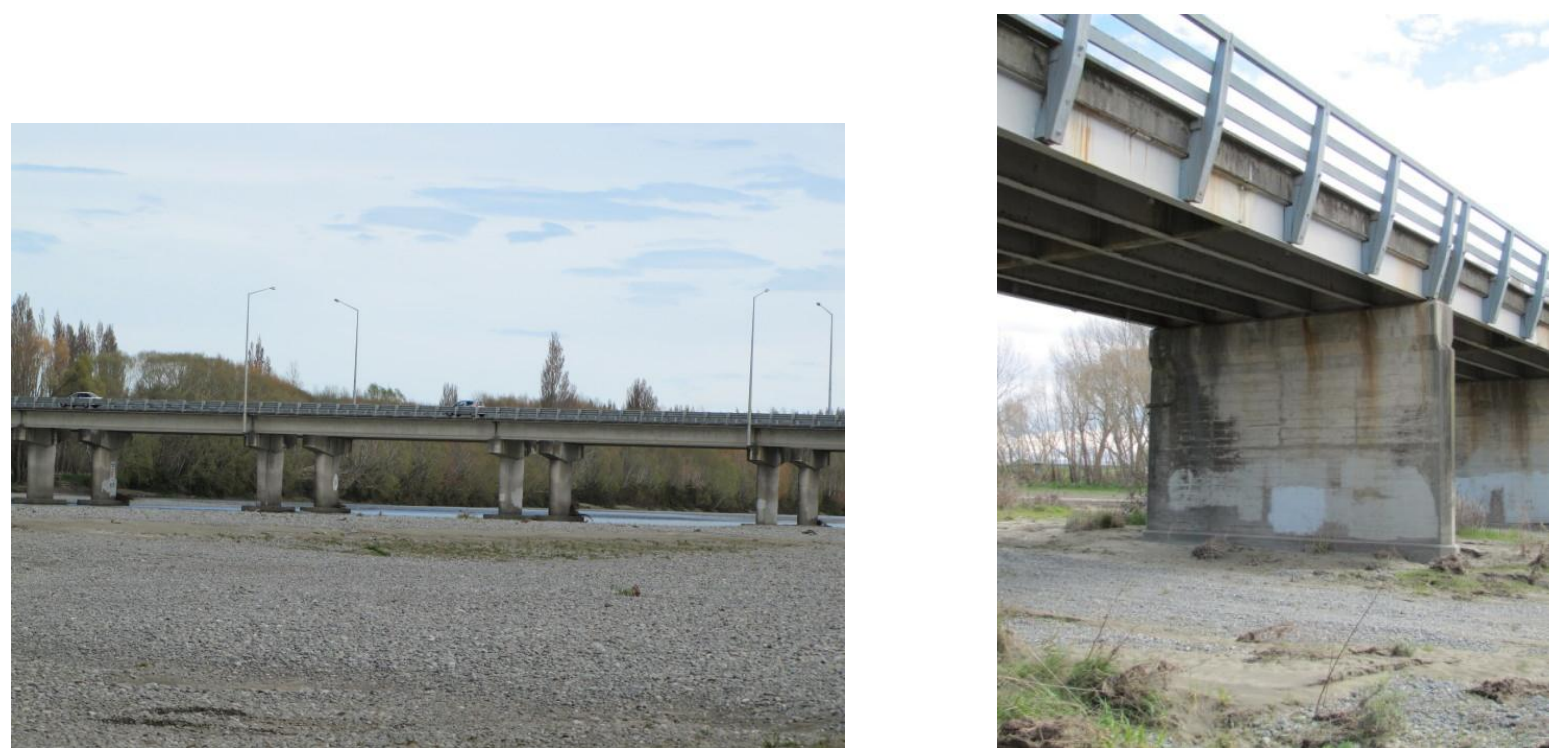

Figure 7.28: Highway bridge across the Waimakariri River. 

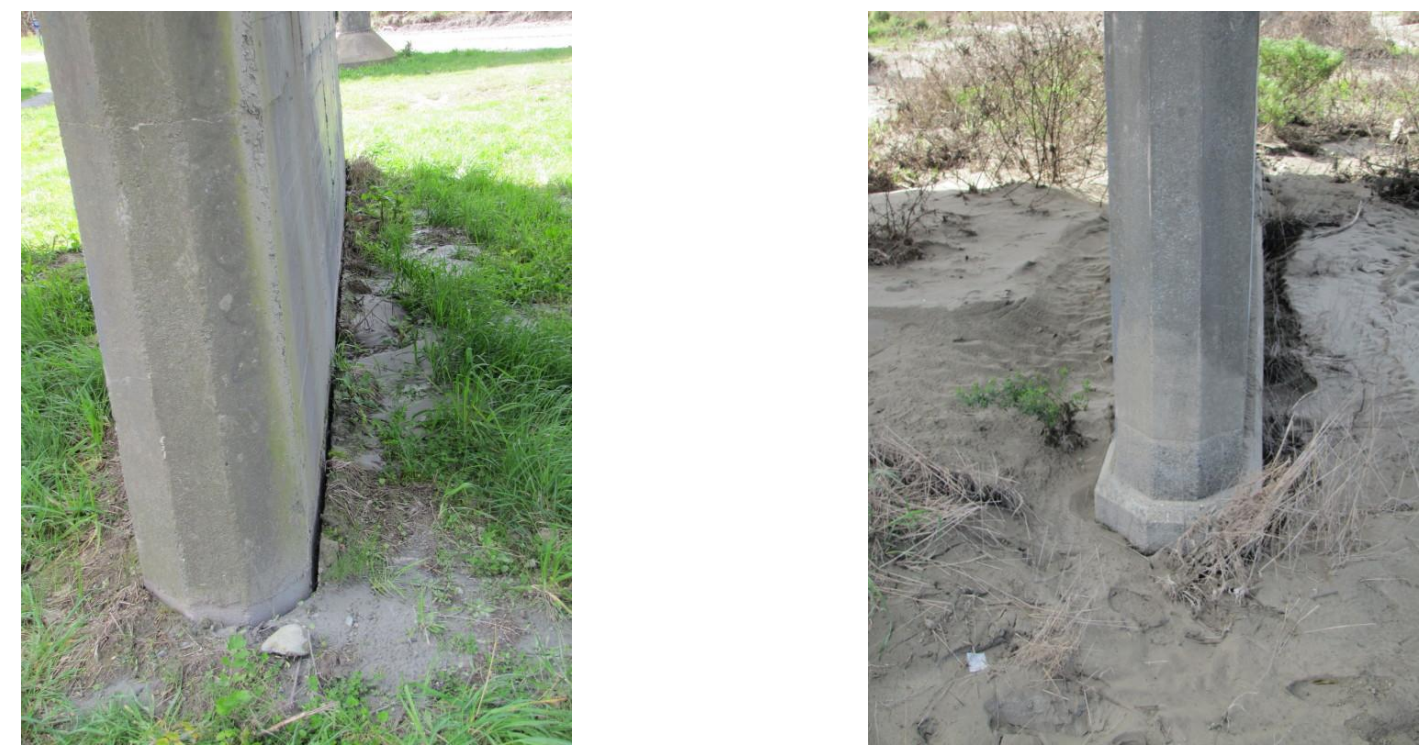

Figure 7.29: Evidence of liquefaction at Highway 1 bridge piers on the north side of the Waimakariri River.
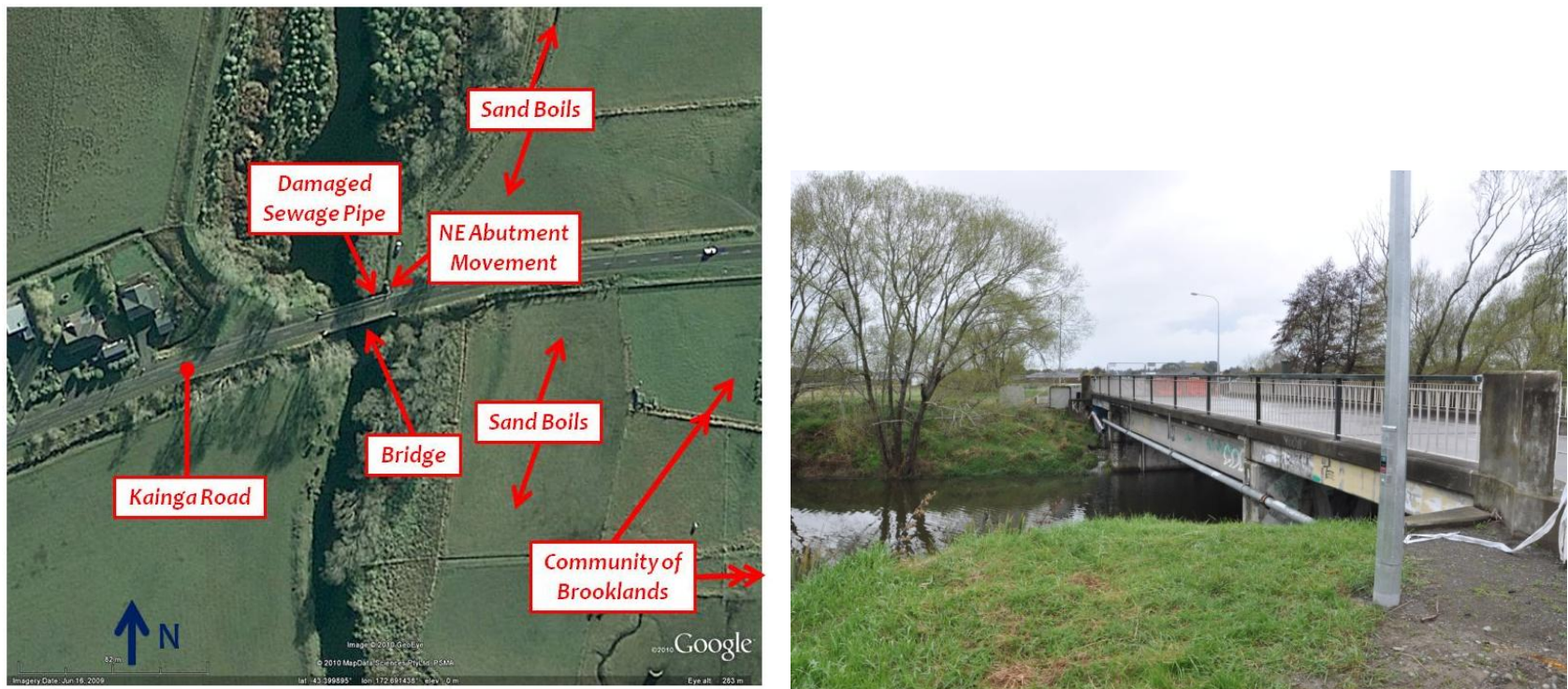

Figure 7.30: Kainga Road Bridge to the Brooklands residential community (a) GoogleEarth image $\left(43.3998^{\circ} \mathrm{S}, 172.6910^{\circ} \mathrm{E}\right)$ and (b) overview of bridge looking west $\left(43.3997^{\circ} \mathrm{S}, 172.6916^{\circ} \mathrm{E}\right)$.

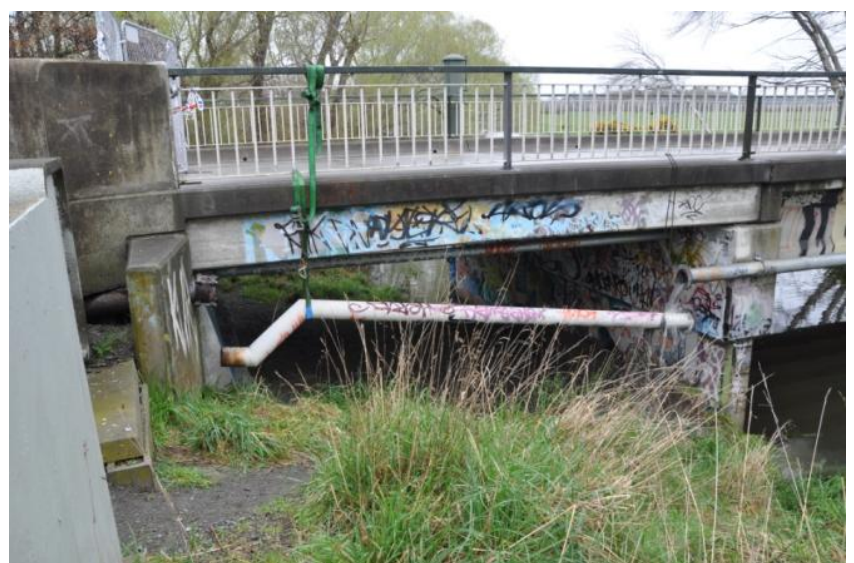

Figure 7.31: Damage to sewage pipe at the Kainga Road Bridge $\left(43.3997^{\circ} \mathrm{S}, 172.6916^{\circ} \mathrm{E}\right)$. 


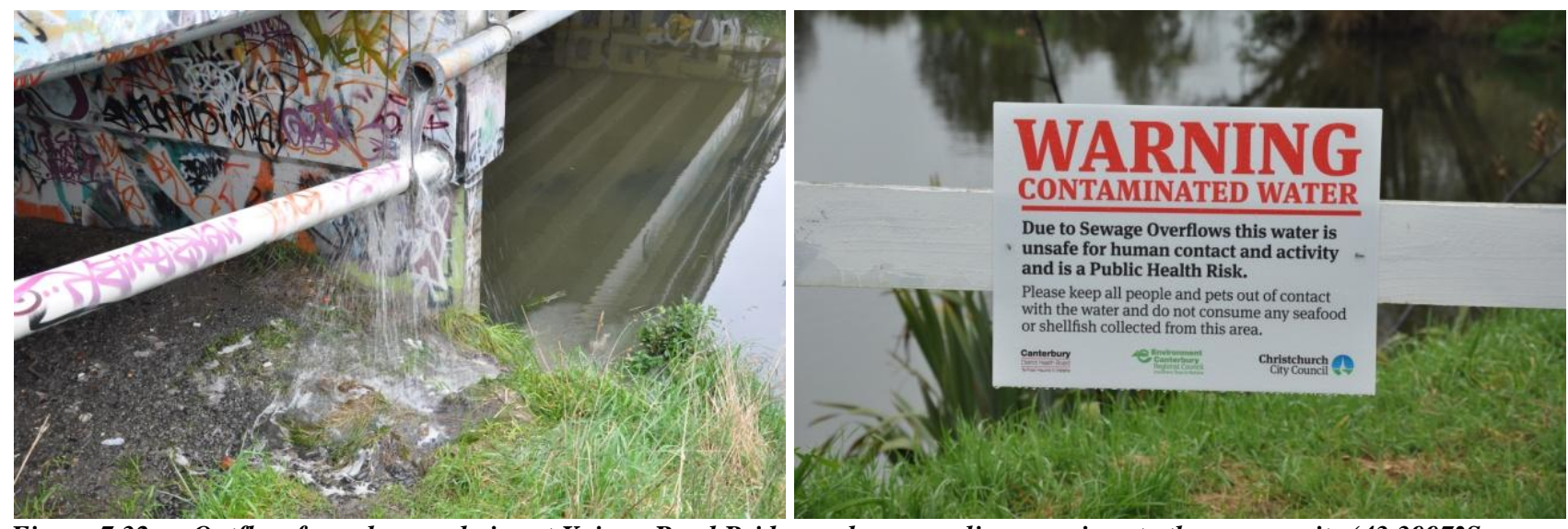

Figure 7.32: $\quad$ Outflow from damaged pipe at Kainga Road Bridge and surrounding warnings to the community $\left(43.3997^{\circ} \mathrm{S}\right.$, $\left.172.6916^{\circ} \mathrm{E}\right)$.
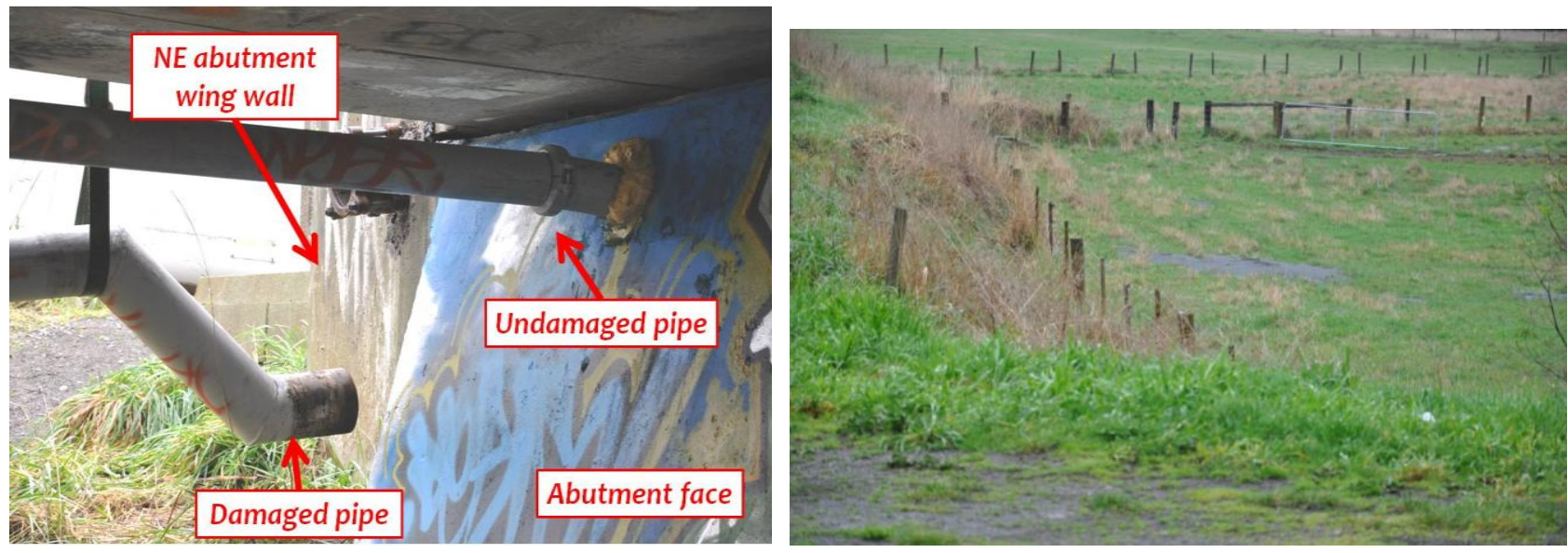

Figure 7.33: Below the East end of the Kainga road bridge (looking northeast). $\left(43.3998^{\circ} \mathrm{S}, 172.6914^{\circ} \mathrm{E}\right)$.

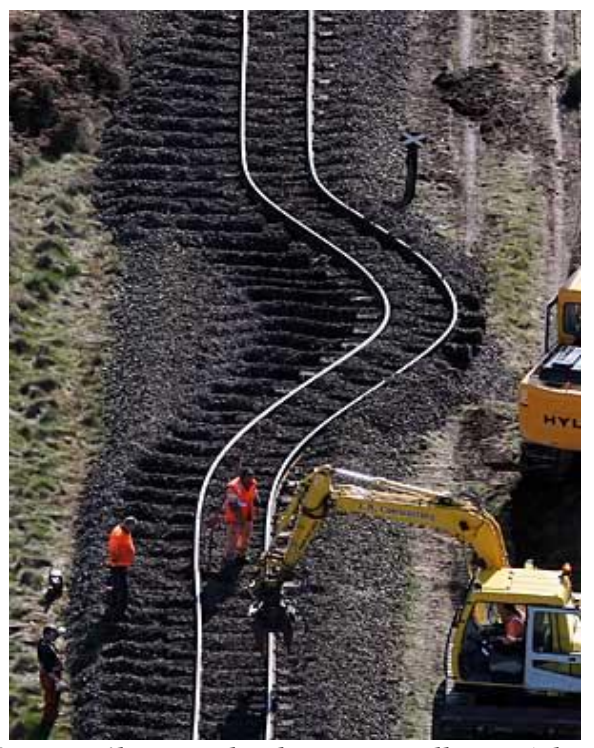

Figure 7.35: Railway Embankment at Rolleston (photo by I. McGregor).

\subsection{Highways}

Most highways and major surface transportation routes remained open following the earthquake, or were only closed temporarily for inspection or minor repairs. Due to a rock fall along Highway 1 between Waipara and Kaikoura, the route remained closed 10 days following the earthquake, but it is not clear if the earthquake was a contributing factor since locals
Figure 7.34: Evidence of liquefaction in surrounding low lying marshlands on the east side of the Kainga road bridge $\left(43.3995^{\circ} \mathrm{S}, 172.6917^{\circ} \mathrm{E}\right)$.

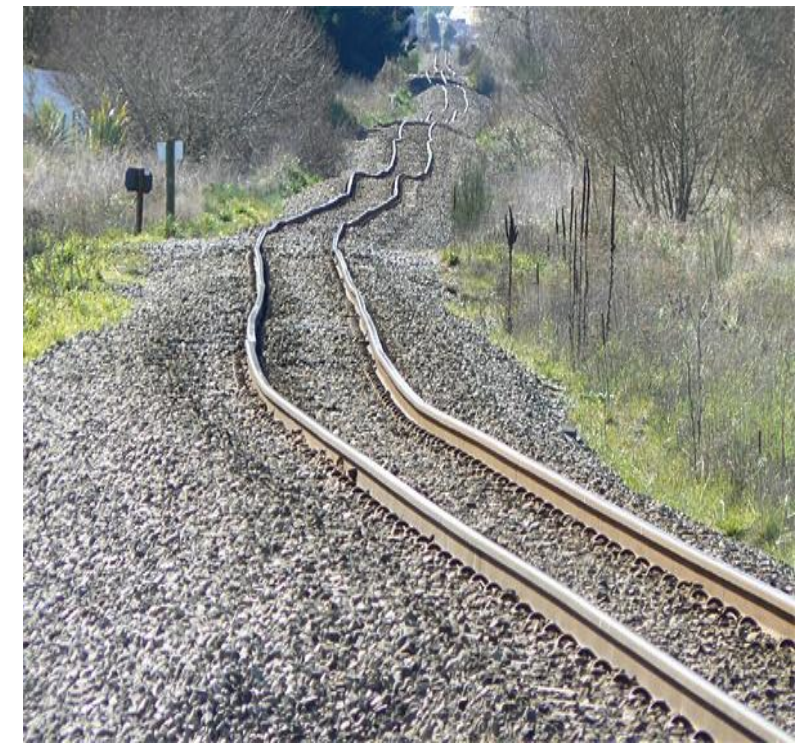

Figure 7.36: Damage to rail line at Woodford Glen (photo by

L.Matthews and J. Overend).

reported the section of roadway had had ongoing problems and there was heavy rainfall in the area prior to the earthquake. An alternative route along Highway 7 to Kaikoura was available. The Highway 74 tunnel from Christchurch to Lyttelton was briefly closed due to a rock fall, and Evans Pass Road was closed in the days following the earthquake due to a rock fall and remained closed after 10 days. While the closure of Evans Pass Road had only minor effect on mobility 
between the Lyttelton Port of Christchurch and the rest of the South Island, it is one of the primary alternative routes between the Port and Christchurch should the tunnel be closed. The tunnel closure, however, only lasted a few hours. In the communities affected by liquefaction, a few roads remained closed 10 days following the earthquake, but alternative access routes were available in all areas.

\subsection{Rail System}

The Canterbury region has a rail system used primarily to carrying coal to the Port for export as well as for tourism trains. Railroad bridges are primarily of steel construction. The New Zealand Natural Hazard Platform Bridge Research Group reported damage to one railroad bridge from the earthquake. Rail service was also impacted from bent rails at the fault trace and as a result of slumping ground in some locations.

Damage to railways embankments was reported by members of the New Zealand reconnaissance team near Rolleston (Figure 7.35) and Woodward Glenn, just south of Kaiapoi (Figure 7.36). In the latter case, the damage appeared due to liquefaction-induced lateral spreading. By the time the team arrived in Rolleston (13 days after the earthquake), the damage to the tracks had been repaired. The Team was informed that the damaged rail line at Rolleston was fixed the day of or the day after the earthquake and that the slumping rail lines at Woodford Glen had been repaired 4 days after the earthquake.

\subsection{Christchurch International Airport}

The Christchurch International Airport was closed temporarily for inspection and minor clean up, but was re-opened with full service within 9 hours of the earthquake. The airports' corporate offices were closed and temporarily relocated.

\subsection{Lyttelton Port of Christchurch}

Lyttelton Port of Christchurch (LPC) is the main port for the Canterbury region and of critical importance to the economy of the South Island. It handles coal, automobiles and fuel products, and about 250,000 TEU of containerized cargo annually. The terminals at the port are of a variety of ages, ranging the 1880 s to current.

The intensity of the Darfield Earthquake in the port area was essentially the operating basis earthquake for the port, having a PGA of $0.33 \mathrm{~g}$ (as measured by a strong motion station within the Port). Port facilities are undergoing strengthening as part of the program to increase lifeline resilience in the region. While some Port facilities sustained significant damage, most Port facilities were operational within hours after the earthquake and no scheduled shipments were missed. By 0700 on 4 September 2010, the two main piers and a portion of the coal terminal were operational. The container terminal was opened by 1500 on 5 September 2010. The coal terminal was fully operational on 8 September 2010, and the liquefied petroleum gas (LPG) terminal was opened on 10 September 2010. Port officials were quite satisfied with the performance, but acknowledge that there will be significant repairs and rebuilding in the coming months.

LPC has three container cranes, each with a $19 \mathrm{~m}$ rail spacing. While there was some lateral (seaward) movement of the deck for the container terminal, no damage to the cranes was noted and they were still performing as intended after the earthquake. The crane rails are closely enough spaced that both rails fit on the wharf deck. Having both rails on the deck appears to have avoided differential movement of the rails (despite the lateral displacement of the deck) and contributed to the good performance of the Port facilities.
The soil profile at the Port typically consists of $10 \mathrm{~m}$ or more soft clay and silty sand layers underlain by rock, along with some un-engineered fill and boulder rip-rap. Liquefiable soils are limited to a few seams within the natural sediments and are believed to have had no impact on the performance of the port. All wharves are on vertical pile foundations, including hardwood timber piles, $600 \mathrm{~mm}$ diameter reinforced concrete piles, $600 \mathrm{~mm}$ square reinforced concrete piles, and steel pipe piles. Many are skin-friction piles that develop their vertical capacity within the underlying clay and sandy soil layers. No damage to any piles was observed, though some were noted to have apparently settled up to $0.3 \mathrm{~m}$, becoming disengaged from the wharf deck. All the wharves underwent limited settlement and lateral deformation, though limited to 0.2 to 0.3 m. Typical damage from settlement and lateral deformation are shown in Figures 7.37-7.39 .

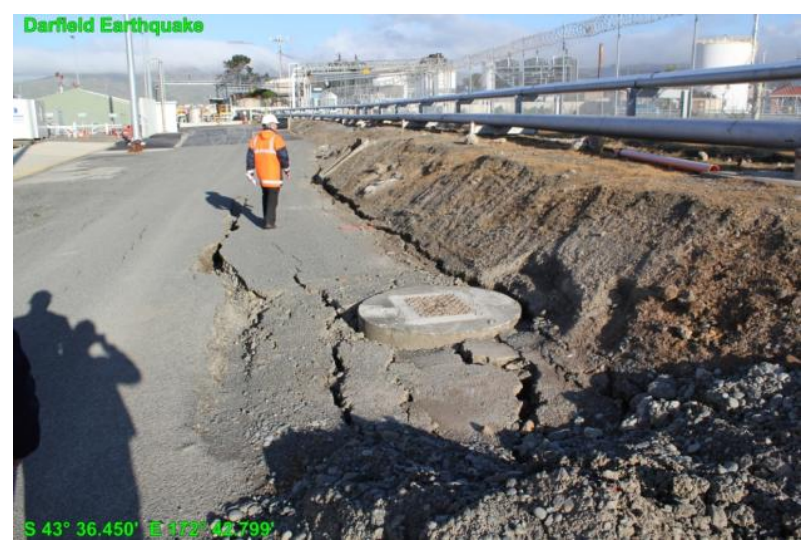

Figure 7.37: Settlement and lateral deformation at fuel transfer facility $\left(43.60750^{\circ} \mathrm{S}, 172.71332^{\circ} \mathrm{E}\right)$.

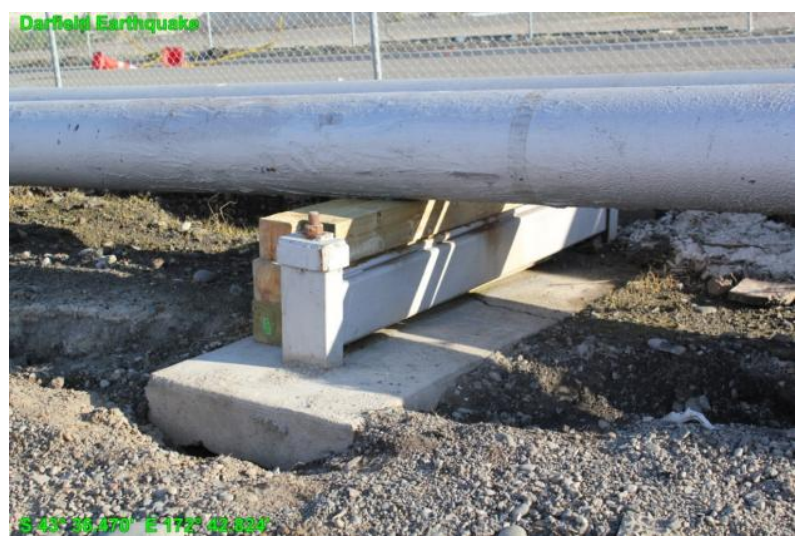

Figure 7.38: Temporary wooden support to accommodate settlement under fuel line.

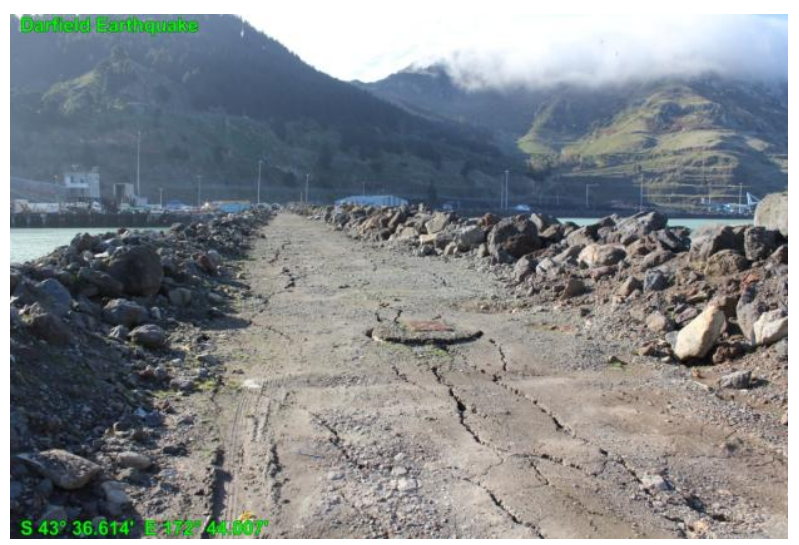

Figure 7.39: Cracking along jetty at eastern end of port. 
The limited wharf movements did open up cracks in the asphalt pavement sections of the wharf deck. In order to keep the port operational, Port officials were considering different temporary repair alternatives, including grouting, sand infill, or crushed rock. Port engineers also expressed concern that the concrete pavement in the backlands areas was bridging over voids that developed due to lateral displacement of retaining walls at the back of the wharves that accompanied lateral displacement of the deck.

The underground $11 \mathrm{kV}$ electric power network remained in service following the earthquake, though the single sub-station at the port did sustain some minor damage.

\subsection{Oil Terminal at the Lyttelton Port of Christchurch}

The Team visited the Oil Terminal side of the Lyttelton Port of Christchurch (Figure 7.40) on 13 September 2010, and the most significant damage was the area leased to the Fulton Hogan Bitumen plant (fultonhogan.com). The Team visited this plant and discussed observations with the plant manager, Steve Platt. He was advised by port officials that approximately $100 \mathrm{~mm}$ of lateral spreading of the wharf supporting the plants facilities had occurred on the eastern water face of the terminal.

As a result of the lateral spreading, as well as liquefaction within the bitumen plant, four tanks and some supporting piping suffered movement and damage. The most severe lateral movement was that of Tank 1 (located at $43.6085^{\circ} \mathrm{S}$, $172.7149^{\circ} \mathrm{E}$ ), which moved laterally $50 \mathrm{~mm}$ towards the water. Tank $2\left(43.608768^{\circ} \mathrm{S}, 172.714651^{\circ} \mathrm{E}\right)$ settled uniformly about $30 \mathrm{~mm}$ causing separation of the connecting bridge between it and a neighbouring tank of like geometry (Figure 7.42). This tank, with dimensions of $12.8 \mathrm{~m}$ high by $13 \mathrm{~m}$ diameter, housed used oil and was nearly filled to capacity at the time of the main shock, weighing an estimated 550 tons. Tanks 3 and $4\left(43.6085^{\circ} \mathrm{S}, 172.7149^{\circ} \mathrm{E}\right)$ were side-by-side and each experienced movement that resulted in pullout of nearly all perimeter anchor bolts at their base. These tanks were $12.5 \mathrm{~m}$ tall by $6 \mathrm{~m}$ diameter with an estimated 150 ton weight at the time of the main shock. Crews were repairing the support anchorage for Tanks 3 and 4 with the retrofit shown in Figure 7.43. No structural damage to the tanks was observed and flexible connections survived the strong shaking with only minor leakage. Asphalt repair using cement injection to fill the lateral spread cracks was on-going during the teams visit (Figure 7.44). Sand boils were also observed at several locations within the plants boundaries. Soil samples of the ejecta indicated the material was clean sand with little to no fines (Figure 7.45).

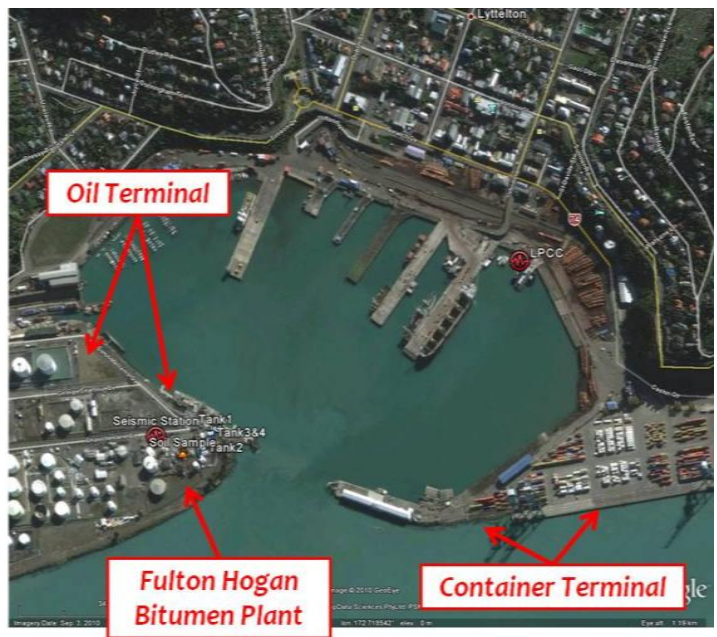

(a)

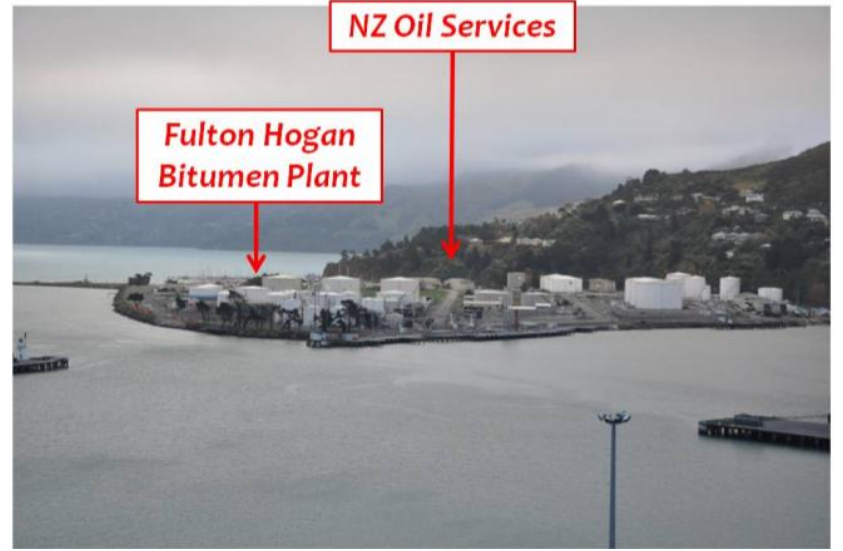

(b)

Figure 7.40: Port of Lyttelton locating the oil terminal area (GoogleEarth image; $43.6088^{\circ} S, 172.7140^{\circ}$ E) and (b) Aerial view of the Fulton Hogan Bitumen Plant (image taken from $43.6068^{\circ} \mathrm{S}, 172.7272^{\circ} \mathrm{E}$ ).

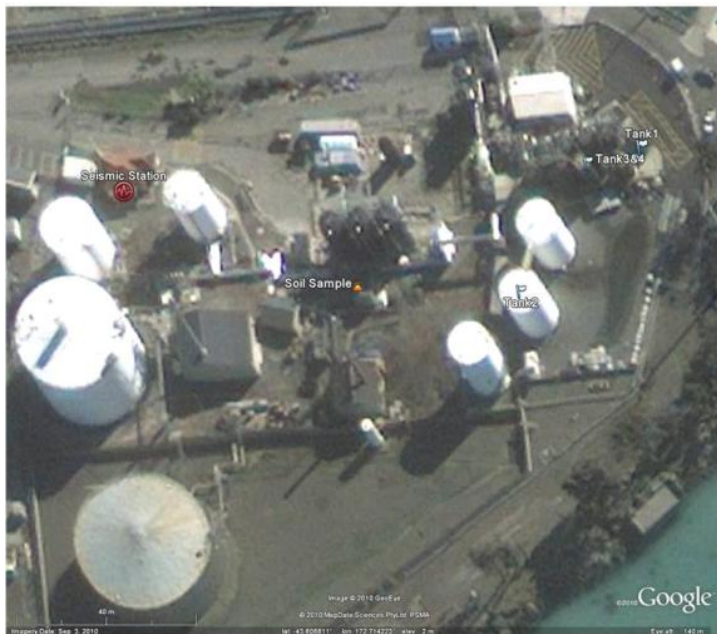

Figure 7.41: Zoomed into the region of the Fulton Hogan Bitumen Plant. (GoogleEarth image; $43.6088^{\circ} \mathrm{S}$, $\left.172.7140^{\circ} \mathrm{E}\right)$.

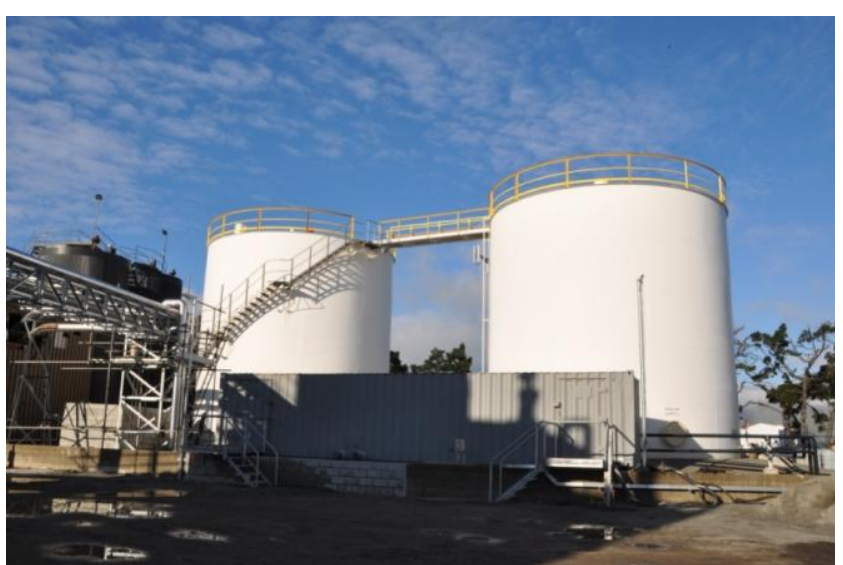

Figure 7.42 Tank 2 (right, large white tank) with Tanks 3 and 4 shown to the left (smaller grey tanks) at the Fulton Hogan Bitumen Plant. (43.6088 ${ }^{\circ}$, $172.7147^{\circ} \mathrm{E}$. 


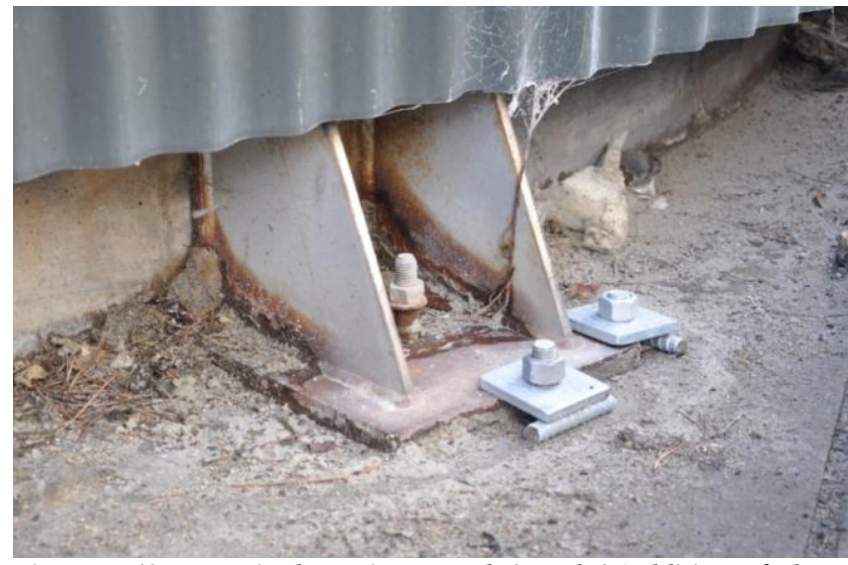

Figure 7.43: Typical repair to Tank 3 and 4 (addition of clamp plates). Note the pullout of the original anchorage. Fulton Hogan Bitumen Plant. $\left(43.6085^{\circ} \mathrm{S}, 172.7149^{\circ} \mathrm{E}\right)$.

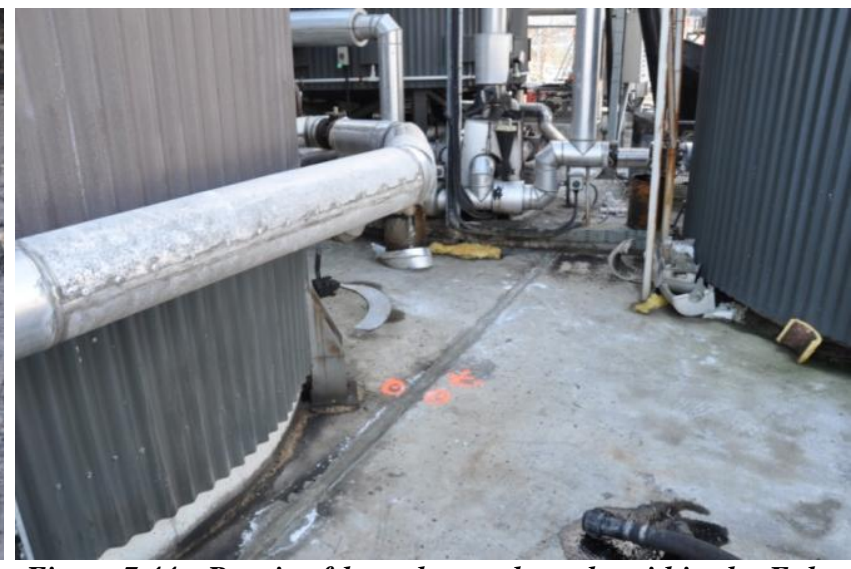

Figure 7.44: Repair of lateral spread cracks within the Fulton Hogan Bitumen Plant, nearby Tank 3. $\left(43.6085^{\circ} \mathrm{S}, 172.7150^{\circ} \mathrm{E}\right)$.
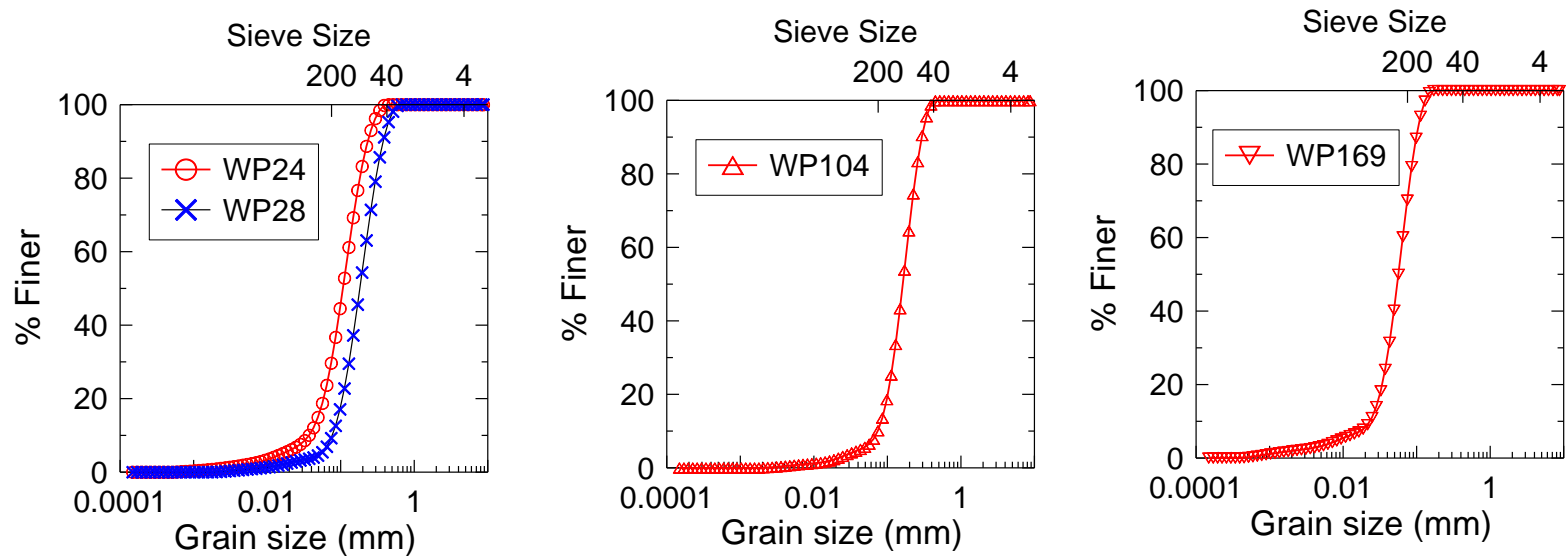

Figure 7.45: Laser diffraction tests of samples taken from ejecta observed at the Fulton Hogan Bitumen Plant. Sample WP169 taken at $43.6087^{\circ} \mathrm{S}, 172.7142^{\circ} \mathrm{E}$.

A seismic station was also identified within the plants boundaries housed within the plant main entry building $\left(43.6086^{\circ} \mathrm{S}, 172.7136^{\circ} \mathrm{E}\right)$, but was not operational for the main shock. Workers attempted to power it following the main shock and Mr. Platt believes it was on during the 5.1 aftershock centred below the Port Hills.

\subsection{Water and Wastewater Systems}

By far the greatest impact on the community was the performance of water and wastewater systems in the Canterbury region. The Christchurch, Selwyn, and Waimakariri Districts all experienced damage to the pipe networks in areas affected by liquefaction, resulting in loss of service and discharge of untreated wastewater into the groundwater and surface water.

In all three districts, drinking water is untreated well water. Water mains are predominately asbestos-cement pipe, with newer pipes being HDPE. All wastewater pipes are concrete bell-and-spigot. Damage to both systems was concentrated in the areas affected by liquefaction.

\subsubsection{Christchurch City Council}

A precautionary water boil advisory was put in place immediately after the earthquake by the Christchurch City Council (CCC) and was lifted on 9 September 2010, with only two minor problems being reported. CCC officials estimate that 6 to $7 \mathrm{~km}$ of water mains will need to be replaced, and the replacement of similar lengths of wastewater pipes are expected. Officials observed that crews performed the equivalent of "a year's worth of maintenance in 6 days."

Damage to the CCC's system was predominately to the water and wastewater mains, as a result of ground movement and floating of manholes. A major problem with sewer lines was influx of liquefied sand and water through breaks in the line. Cleaning sand out of sewer pipes and pump stations was a major factor affecting restoration of service. Repair crews found pipes that were simply pulled apart, while others were crushed at the joints. No problems were associated with pipes crossing bridges that CCC officials were aware of. CCC officials expressed concern about voids that may have developed beneath pavements due to the estimated 11,000 tons of sand removed from pipes and pump stations (corresponding to a potential void volume of approximately $9,000 \mathrm{~m}^{3}$ ).

All new pump stations have flexible joints and performed well. At older stations, one pipe with a rigid connection was sheared (at Halswell) and one water pump was lost (which was identified as vulnerable and scheduled to be replaced). All pumping stations have back-up power supplies, and all worked as intended. The wastewater treatment plant in Christchurch was unaffected by the earthquake, though an increase of flows into the plant of up to $20 \%$ were observed as a result of groundwater inflow through the pipe breaks.

CCC officials indicated that restoration of drinking water took a priority over wastewater, and that work had yet to start on the storm sewer system. Ongoing problems included additional pipe breaks and removal of silt and sand from pipes 
and pumping stations. The CCC asset management plan calls for pipe replacement if three breaks are observed in any pipeline over the period of one year. They are now doing a cost analysis of clearing pipelines by jetting, Closed-Circuit TV (CCTV) inspection, and repair of existing pipelines versus abandonment and replacement. As part of the efforts to improve resilience, CCC spends about $1 \%$ of their maintenance budget on resilience upgrades.

\subsubsection{Selwyn District Council}

Most of the water and wastewater networks in the Selwyn District council (SDC) performed quite well. Very few breaks were reported, mostly in foothill areas. A blanket water boil advisory was lifted 5 days after the earthquake. The biggest reported problem was the new (less than 3 years old) wastewater treatment plant had to be taken offline, eliminating $1500 \mathrm{~m}^{3} /$ day of capacity. Flows were fortunately redirected to the old plant that had been recently replaced, but had not yet been completely taken out of service. The new plant was running again in 9 days, near $100 \%$ after 10 days.

Loss of power to pumping facilities was the most common form of outage. Under established protocols, the power network shuts down automatically after a major earthquake, whether there is damage or not, and service is not restored until inspections indicate it can be restored safely. Most of the large facilities had stand-by power generators and some mobile generators were available and used. However, SDC engineers expressed the need for additional mobile units. The mobile generators that were available were rotated in order to provide residents with at least intermittent services. One complicating factor was the rise in the water level of several drinking water wells. According to SDC engineers, the water level in one well rose by $5.3 \mathrm{~m}$, another by $3 \mathrm{~m}$, and two went artesian and water was pouring out of the electrical connections in the well head.

\subsubsection{Waimakariri District Council}

While the types of problems were similar, the Waimakariri District Council (WDC) was much harder hit than Christchurch, primarily due to the extensive liquefaction and the associated lateral spreading in Kaiapoi. A precautionary water boil advisory was still in effect 10 days after the earthquake. It was to be lifted on 12 September 2010, but a single sample tested positive for E-Coli and the advisory was extended.

WDC officials estimate that the system was providing water to $70 \%$ of residents within one day of the earthquake, $85 \%$ after the second day, and nearly $100 \%$ by the ninth day (noting that the water was intentionally not restored to several damaged structures). This restoration was to the private property lines, beyond which service is the responsibility of individual property owners. However, WDC crews were also working with residents to provide service all the way to their homes. In hindsight when considering repairs, WDC officials wondered if they could have restored the water service sooner by using more temporary above-ground flexible piping, as was done on the final days of restoration. Ten days after the earthquake (on 13 September 2010 ), $60 \%$ of Kaiapoi's wastewater was being collected and treated at the wastewater treatment plant. However, $40 \%$ of sewage system flows were still being discharged into the river untreated. City engineers estimated that the amount of untreated wastewater would be reduced to $5 \%$ by September 17 .

WDC officials felt the biggest problems were the deep gravity wastewater mains. In many cases these mains were 3 to 4 meters below ground surface with ground water only $2 \mathrm{~m}$ deep. In addition, some of the mains are located in the backyards of private residences, making access and subsequent repairs more difficult.

\subsubsection{Residential Communities of Spencerville and Brooklands}

In a number of residential communities, sewage and potable water were problematic immediately following the main shock. Perhaps hardest hit were the communities of Spencerville and Brooklands. At the time of the Teams visit on 13 September 2010, neither community had a functioning wastewater collection system, and Brooklands did not have potable water. Liquefaction along Lower Styx Rd, the primary connection between these two communities, caused ground subsidence, a rise in the water table, and uplifting of 25 manholes (Figure 7.46). Construction workers were dewatering the region during the Team's visit and informed us that the manholes were $4 \mathrm{~m}$ deep. The manholes were approximately $280-460 \mathrm{~mm}$ above the existing road surface (Figure 7.47).

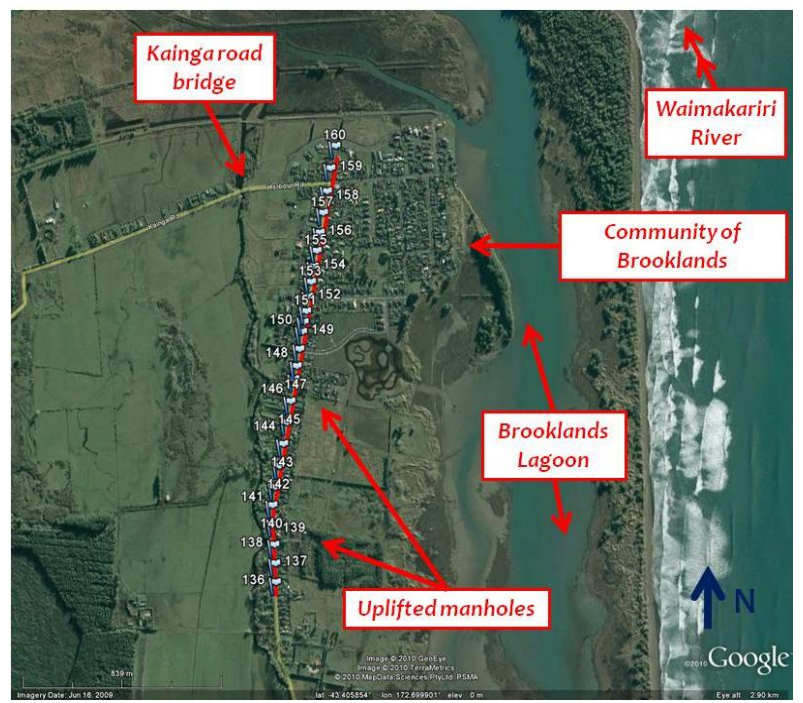

Figure 7.46: Approximately $2 \mathrm{~km}$ stretch along Lower Styx Road with observed uplifted manholes. (GoogleEarth image; $43.4059^{\circ} \mathrm{S}$, $\left.172.6999^{\circ} \mathrm{E}\right)$. Waypoints $136-160$ represent locations of elevated manholes.

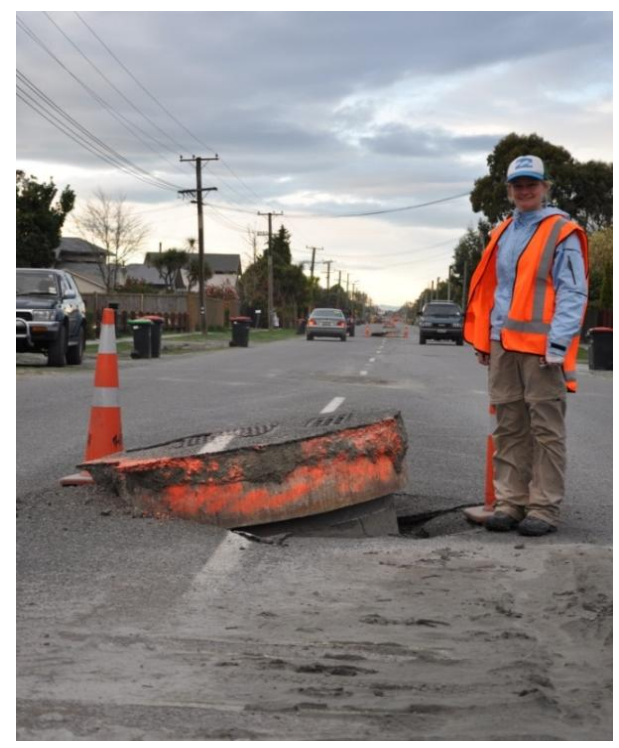

Figure 7.47: Uplifted manholes along Lower Styx Road, note the continuation of pattern in the foreground $\left(43.4113^{\circ} \mathrm{S}, 172.6930^{\circ} \mathrm{E}\right)$. 


\subsection{Electric Power}

The electric power system performed quite well following the earthquake, with much of the good performance attributed to the hardening of the system over the last decade. No problems were noted with the generation or transmission system, and problems with the distribution systems were primarily associated with liquefaction.

Orion, the primary service provider in Christchurch, reported restoring power to $90 \%$ of customers within one day of the earthquake, with much of the remaining $10 \%$ not being restored as a precautionary measure. Each substation was individually inspected prior to restoring power, and many of the older switches were manually reset after being tripped during the earthquake. Both $66 \mathrm{kV}$ and $11 \mathrm{kV}$ lines are part of the system, with most of the lines located underground. The Christchurch network is old and, having many alternate routes, Orion was able to re-route power to provide service even though line breaks still existed. Of the 20 high voltage cable faults detected, 11 still needed to be repaired 10 days after the earthquake. Only two substations in Christchurch went offline during the earthquake, both from settlement as a result of liquefaction. The last back-up generator was taken off-line on 8 September 2010.

\subsection{Waste Management \& Landfill}

The Kate Valley Landfill, operated by Canterbury Waste Services, is the regional waste disposal facility for the affected area. However, the Christchurch City Council opened up a cell at the closed Burwood Landfill facility to accommodate the increased volume of waste generated by earthquake response and recovery efforts. Furthermore, limits on the volume of incoming waste were temporarily waved at Kate Valley and the facility increased working hours to accommodate the increased volume of waste after the earthquake.

Canterbury Waste Services (CWS) resumed operation and household collection of waste two days after the earthquake. CWS uses collection centres throughout region and transfers the waste to Kate Valley Landfill approximately 65 kilometres north of the city. On Sunday, the day after the earthquake CWS began hauling waste collected before the earthquake from their collection centres to clear them in anticipation of increased waste tonnage. For a two week period following the event, the tonnage delivered to the landfill approximately doubled from 800-900 tons/day to $1700-1800$ tons/day. Demolition debris collected in Christchurch was taken to recycling centres, with residual waste taken to the reopened cell at the Burwood landfill.

The CCC and CWS recycle approximately $70 \%$ of the total organic waste generated in the region, which means that most of the waste entering the regional landfill has a low water content and does not decompose. One of CWS's concerns was the increased amounts of high water content waste from grocery stores and grocery distribution centres entering the landfill after the earthquake and creating a potentially unstable waste body. CWS received permission to temporarily spread high-liquid waste loads on the ground at a local quarry to allow liquids to drain prior to disposal in the landfill. CWS also mixed incoming high water content wastes with MSW at the collection centres, thus reducing the water content prior to arrival of the waste at the landfill.

The Team visited the Kate Valley landfill and found that it performed as designed. The landfill is located approximately 85 kilometres from the epicentre. The landfill is a valley fill with 2.5:1 slide slopes. The lining configuration consists of an encapsulated membrane back geosynthetic clay line/geomembrane system composed of a $0.4 \mathrm{~mm}$ high density polyethylene (HDPE) geomembrane with $6 \mathrm{~mm}$ of dry bentonite adhered to it, overlain by a $1 \mathrm{~mm}$ HDPE liner. No slipping of the waste body or damage to the lining system was reported by the operator. No other lined structures such as dairy milking barn wastewater ponds or lined reservoirs had reported damage.

\subsection{Other Lifelines}

Other lifelines such as landline and cellular and telephones, fuel supply, television and radio performed well in the earthquake. While some land telephone lines were out of service, no interruption of cellular telephone service was observed. Service providers were aware of the potential for tower battery drawdown in an emergency, as was observed in the 2010 Chile Earthquake, but had installed generators at key locations and have agreements with local residents to keep them fuelled.

No interruption in fuel from Lyttelton Port of Christchurch was observed. Television broadcasting facility was undamaged and had four days of fuel in preparation for emergency power outages. The local bus service was restored on 7 September 2010

\section{ACKNOWLEDGEMENTS}

Primary support for the GEER participants in this work was provided from grants from the U.S. National Science Foundations (NSF) as part of the Geo-engineering Extreme Event Reconnaissance (GEER) Association activity through an NSF RAPID GRANT and CMMI-00323914. The GEER team reconnaissance was performed in coordination with teams from EERI and PEER. Primary support for the New Zealand participants was provided by the University of Canterbury and University of Auckland. The Japanese participants were partially supported by the Japanese Geotechnical Society (JGS). The University of Canterbury geotechnical group is particularly grateful to Prof. Susumu Yasuda, Tokyo Denki University, Japan, and JGS reconnaissance members for quickly arranging the SWS gear and making it available for continuous testing in the area affected by the earthquake.

Additional support for our efforts was provided through data/information sharing and 'clearing house' activities of a large research group re-convening every night at Environment Canterbury (ECan), following the intense field reconnaissance during the day. We particularly appreciate the support of Peter Wood (President of New Zealand Society for Earthquake Engineering), Dr. Grant Dellow (GNS), Dr. Kelvin Berryman (Natural Hazards Platform Manager, GNS) and Helen Grant (ECan) for the overall assistance and providing quick access to properties/areas of interest. This also included a helicopter flyover of the affected area for three members of the team, in order to jump-start the reconnaissance effort.

Mike Jacka and Kirsti Murahidy, from Tonkin and Taylor, Christchurch, provided valuable information related to liquefaction-induced damage to residential properties. Steve Christensen, from Beca, Christchurch, provided valuable input in the section on Bromley Sewage Treatment Plant.

University of Canterbury postgraduate students Joshua Bird, Kim Rait and Patrick Kailey, and also Josh Zupan, University of California, Berkeley, and Barbara Chang, University of California, San Diego, assisted the reconnaissance, data management and preparation of this paper. 


\section{REFERENCES}

Andrus, R.D., and Stokoe II, K.H. (2000). Liquefaction resistance of soils from shear wave velocity. Journal of Geotechnical and Geoenvironmental Engineering, ASCE 126(11):1015-1025.

Ambraseys, N.N. (1988). Engineering Seismology. Earthquake Engineering and Structural Dynamics, 17: 1105.

Berrill, J.B., Mulqueen, P.C. and Ooi, E.T.C. (1994). Liquefaction at Kaiapoi in the 1901 Cheviot, New Zealand, Earthquake. Bulletin of the New Zealand Society for Earthquake Engineering, 27(3): 178-189.

Boyle, Tony (2010). Personal Communication, 27 September 2010 .

Brown, L.J. and Weeber, J.H. (1992). Geology of the Christchurch Urban Area. Institute of Geological and Nuclear Sciences.

CH2m Beca Ltd. (2003). Kaiapoi Sewage Treatment Plant Assessment of Environmental Effects for Discharge to Land, Report prepared for Waimakariri District Council.

Chanerley, A.A. and Alexander, N.A. (2010). Obtaining estimates of the low-frequency 'fling', instrument tilts and displacement timeseries using wavelet decomposition, Bull. Earthquake Eng., 8: 231-255.

Chiou, B.S.J. and Youngs, R.R. (2008). An NGA Model for the average horizontal component of peak ground motion and response spectra, Earthquake Spectra, 24: 173-215.

Cowan, H., Nicol, A. and Tonkin, P. (1996). A comparison of historical and paleoseismicity in a newly formed fault zone and a mature fault zone, North Canterbury, New Zealand. J. geophys. Res., 101: 6021-6036.

DeMets, C., Gordon, R. G., Argus, D. F. and Stein, S. (1994). Effect of recent revisions to the geomagnetic time scale on estimates of current plate motion. Geophysical Research Letters, 21: 2191-2194.

Engineering Darfield Earthquake Blog. (http:// db.nzsee.org.nz:8080/en/web/lfe-darfield2010/home)

Environment Canterbury (ECan): http://ecan.govt.nz/ publications/General/solid-facts-christchurchliquefaction.pdf

Forsyth, P., Barrell, D. and Jongens, R. (2008). Geology of the Christchurch area. GNS QMap, 1:2500 000 Geological Map 16, P. 67.

Google Inc. Google Earth, [map] (2010). Generated by Liam Wotherspoon: using Google Earth. http://www. google.com/earth/index.html (generated October 5, 2010).

Griffiths, G.A. (1979). Recent Sedimentation History of the Waimakariri River, New Zealand. Journal of Hydrology (New Zealand), 18: 6-28.

Housner, G.W. (1952). Spectrum Intensities of Strong-Motion Earthquakes. Proc. Symp. Eathquake and Blast Effects on Structures, Engineering Research Institute, Los Angeles.

Howard, M., Nicol, A., Campbell, J. and Pettinga, J.R. (2005). Holocene paleoearthquakes on the strike- slip Porters Pass Fault, Canterbury, New Zealand, N.Z. J. Geol. and Geophys., 48: 59-74.
Ingham, J. and Griffith, M. (2010). Performance of unreinforced masonry buildings in the Darfield Earthquake (First impressions). Reported at the New Zealand Society for Earthquake Engineering meeting.

Japanese Standards Association (1975). Japanese Industrial Standard: Method of Swedish Weight Sounding - JIS A 1221 (1975), 1995 Revision.

Larned, S.T., Hicks, D.M., Schmidt, J., Davey, A.J.H., Dey, K., Scarsbrook, M., Arscott, D.B. and Woods, R.A. (2008). The Selwyn River of New Zealand: A Benchmark System for Alluvial Plain Rivers. River Research and Applications, 24: 1-21.

Moon, L. (2010). Initial assessment of unreinforced masonry buildings performance in the 2010 Darfield Earthquake. Reported at the New Zealand Society for Earthquake Engineering Darfield Earthquake Blog. (http://db.nzsee.org.nz:8080/en/web/lfe-darfield2010/home)

Norris, R.J. and Cooper, A.F. (2001). Late Quaternary slip rates and slip partitioning on the Alpine Fault, New Zealand. J. Structural Geol., 23: 507- 520.

NZ Aerial Mapping (2010). NZ Aerial Mapping. Kaiapoi, [air photo]. Wellington, New Zealand.

Palermo et al. (2010) Preliminary Bridge Findings. report by the Darfield Earthquake Natural Hazard Platform Bridge Research Group.

Plan of portion of the plains of Canterbury, [map]. 1:126,720. Christchurch, NZ: Ward \& Reeves, 1865.

Pettinga, J.R., Yetton, M.D., Van Dissen, R.J. and Downes, G.L. (2001). Earthquake source identification and characterisation for the Canterbury region, South Island, New Zealand. Bull. of the N.Z. Soc. For Earthquake Engineering, 34(4): 282-317.

Quigley, M., P. Villamor, K. Furlong, J. Beavan, R. Van Dissen, N. Litchfield, T. Stahl, B. Duffy, E. Bilderback, D. Noble, D. Barrell, R. Jongens, A. Klahn, A. Smith, T. Wilson, S. Cox and J. Ristau. Mw 7.1 Earthquake on Unknown Strike-slip Fault Rattles New Zealand's South Island. EOS, Transactions, America Geophysical Union (in review).

Rathje, E., Bachhuber, J., Cox, B., French, J., Green, R., Olson, S., Rix, G., Wells, D. and Suncar, O. (2010). Geotechnical Engineering Reconnaissance of the 2010 Haiti Earthquake. GEER Association http://www.geerassociation.org/GEER_Post\% 20EQ\%20Reports/Haiti_2010/Cover_Haitil0. html, Report No. GEER-021.

Robb, J.A. (1974). An Ecological Study of the Bromley Oxidation Ponds and Surrounding Environs, PhD Thesis, University of Canterbury.

Shell New Zealand (1935). Christchurch and area, [map] 1:63,360. Wellington, New Zealand.

Stokoe II, K.H., Wright, S.G., Bay, J.A. and Roesset, J.M. (1994). Characterization of geotechnical sites by SASW method, p. 1-24. In R.D. Woods (Ed.). Geophysical characterization of sites, IBH Oxford Press, New Delhi.

Te Ara Encyclopedia of New Zealand (2010). http://www.teara.govt.nz/en/floods/6/7. 
Von Thun, J., Roehm, L., Scott, G. and Wilson, J. (1988). Earthquake Ground Motions for Design and Analysis of Dams, Earthquake Engineering and Soil Dynamics II Recent Advances in Ground Motion Evaluation, Geotechnical Special Publication, 20: 463-481.

Waimakariri District Council (2010). Personal Communication, 29 September 2010.

Wallace, L., Beavan, J., McCaffrey, R., Berryman, K. and Denys, P. (2007). Balancing the plate motion budget in the South Island, New Zealand using GPS, geological and seismological data. Geophys. J. Int., 168: 332-352.

Ward and Reeves (1985). Plan of portion of the plains of Canterbury, [map] 1:126,720 (1865). Christchurch, New Zealand.

Wells, D.L. and Coppersmith, K.J. (1994). New Empirical Relations among Magnitude, Rupture Length, Rupture Width, Rupture Area, and Surface Displacement. Bulletin of the Seismological Society of America, 84(4): 974-1002.

Youd, T.L., Idriss, I.M. et al. (2001). Liquefaction resistance of soils: summary report from the 1996 NCEER and 1998 NCEER/NSF workshops on evaluation of liquefaction resistance of soils. Journal of Geotechnical and Geoenvironmental Engineering, 127: 297-313. 